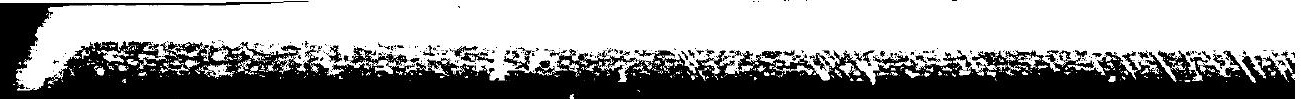
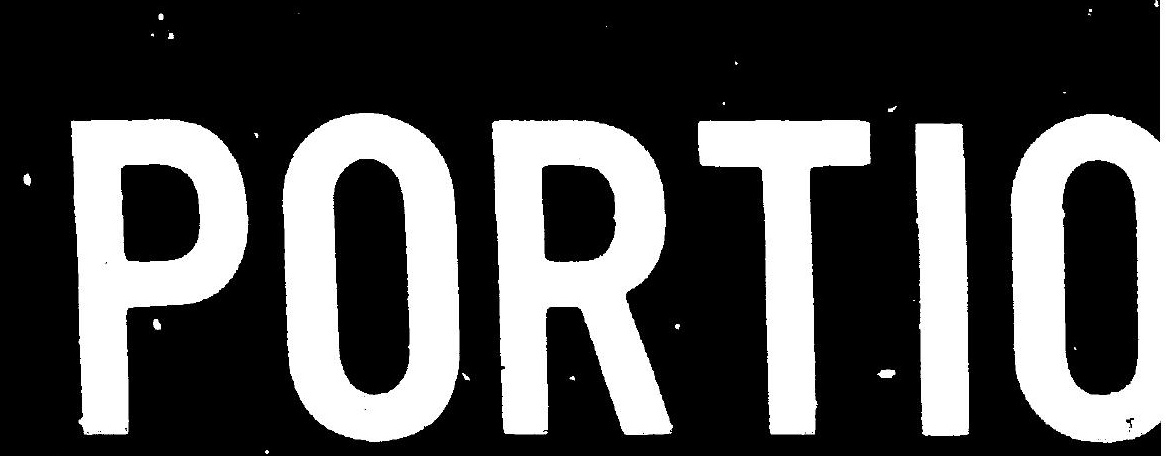

;
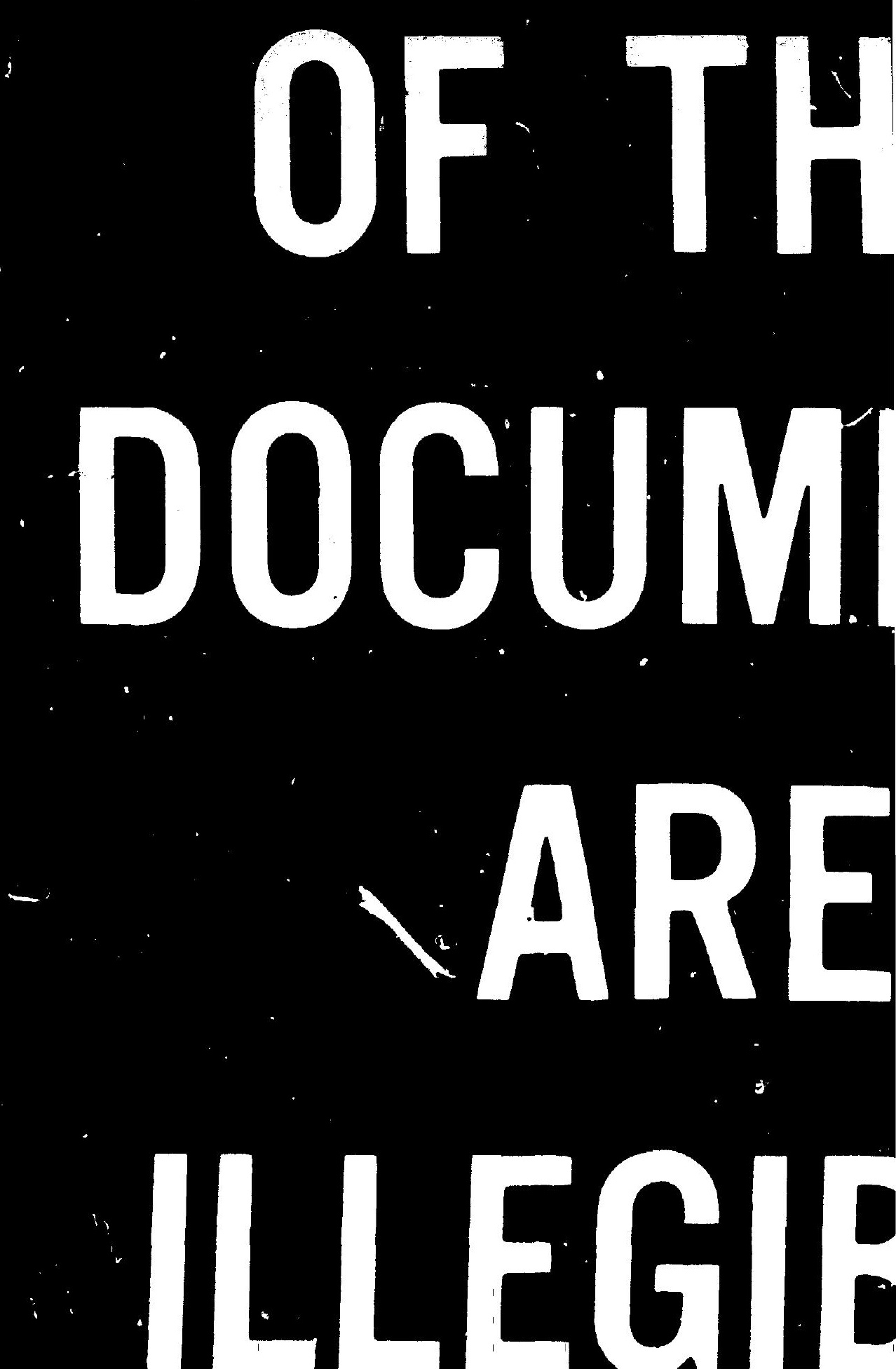
ORNL-5805

Distribution Category UC-77

Gas Cooled Reactor Technology

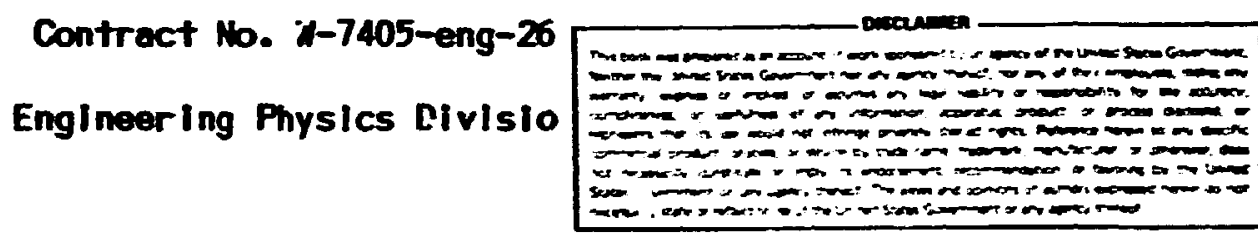

REVIEN OF ORAL-TSF SHIELDING EXPERIMENTS FOR THE GAS-COOLED

FAST BREEDER RENCTOR PROGRM

\author{
L. S. Abbott \\ D. T. Ingersol I \\ F. J. Muckenthaler \\ C. 0. Slater
}

D. E. Bartine, Shielding Program Manager

Manuscript Completed: Decenber 1981

Date Published: January 1982

Thils Work Sponsored by

J.S. Departwent of Energy

Offlice of Reactor Research and Tecinolegy

$\bullet$

4
OAK RIDGE MATIONAL LABORATORY

Oak Rl dgo, Tennesseo 37830

operated by

UNION CARBISE CORPORATION

for the

DEPARTIENT OF ENERGY 
RASTRACT

Ouring the perlod between 1975 and 1980 a serles of experinents ves performed of the Oewl Tower Shlelding Fac!lity In support of the shleld design for a 300-m(e) Ges Cooled Fast Breeder Demonstration PIant. Although the GCFR progren wes cancelled In

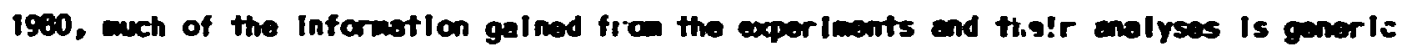
and therefore applicable to ctter systems. In eech case the epproech wes to wock up a region of the ECFR reactor core and/or shleld and to meesure the Intensitles (and energles when poss(b/e) of reactor rodiation; penetrating through the reglon. In addition, calculations of the panatrating rediations were performed, using the seme methods that were to be epplled or had bean applifed to the CorR systen Itself. unen required, new calculational technlques were doveloped. Agreament between the calculated and messured resulte vallated the athod for application In the enalysis of the GCFR shlelding design. This report revieus the experiants and calculations, wich Includec studles of: (1) neutron streasing In the he: Iu coolant passagureys in the GCrR core; (2) the effectiveness of the shleld designed to protect the rastor gild plate from raclation deane; (3) the edequacy of the radial shleld in protecting the PCRV (prestressed concrete reactor vessell from radiation de go; (4) neutron streaing between abutting sections of the redial shleld; and (5) the effectiveness of the exit shlele in reducing the neutron fluxes in the upper plenu region of the reactor. in general, good agrament batween the calculated and nasured fluxes was obtalmed for all experiments.

\section{MOXMONLEDEEMENT}

The authors uith to express thelr appreclation to Katie Laworn for typlng and proofreading ass letence. 


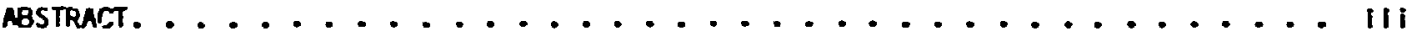

MCKMONLEDGERERT ................................. . . IIi

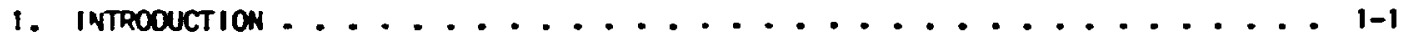

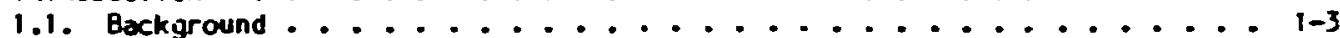

1.2. ORul Shlelding Analysis Phllosophy ................. i-4

1.3. The Tower Shielding Facillty................... 1-5

1.4. Crganization of Report..................... 1-5

1.5. Reforences............................ 1-7

2. THE GAS TOOLED FAS! BREEDER REACTOR. ................... 2-

2.1. Pr Incipal Fejtures of the Nuclear Stean Supply Systen. . . . . . . 2-3

2.2. Reactor Shlelding....................... 2-3

3. TSF EXFERIMENTAL TECHNIQUES. .....................

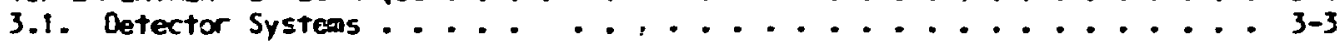

3.1.1. Hornyak Button..................... 3-3

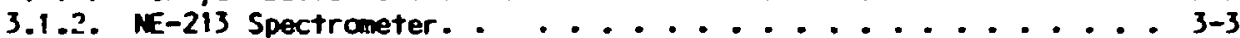

3.1.3. Borner Balls ........................ 3-4

3.1.4. Hydrogen Counter ................... 3-5

3.1.5. Thermoluninescent Dosineter (TLO).............. 3-5

3.2. Analysis of Experimental tirrcrs. . . . . . . . . . . . . 3-6

3.3. References ......................... 3-8

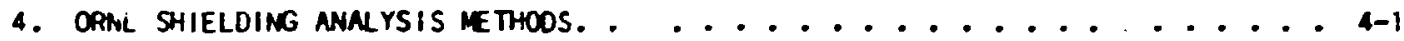

4.1. The Major Trausport Codes. . . . . . . . . . . . . . . . 4-3

4.1.1. The DIscrete Ordinates Codes COT and ANISN ......... 4-3

4.1.2. The Monte Carlo Codf: LDRSF. ...............4-4

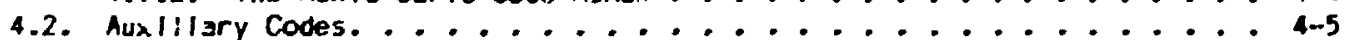

4.3. Comparing Calculated and Mezsured Results. . . . . . . . . . . 4-6

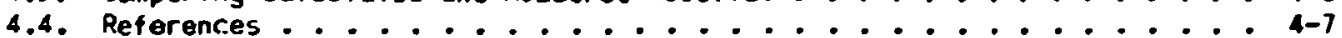

5. STUDIES OF MEUTPON STFENMIING IN GCFR CORE MOCKUPS: SINGLE-CELL EXPERIMENT . 5-1

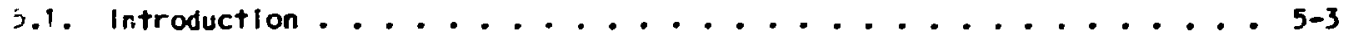

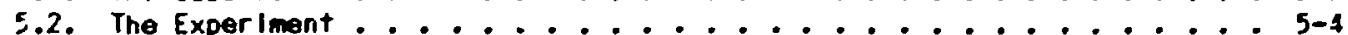

5.3. Preanalysis of the Exper iment. . . . . . . . . . . . . . . 5-7

5.3.1. Selection of Ang:lar Quadrature Set............ 5-7

5.3.2. Definition of Source................... 5-8

5.3.3. Transport Calculations .................. 5-8

5.3.4. Transport Calculatioris for Cell Assemblios......... . 5-8

5.4. Postanziysis of the Experiment; Comparison of Calculated

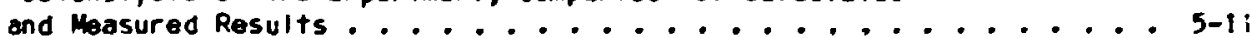

5.4.1. Definition of Source.................. 5-1i

5.4.2. Transport Calculations for Spectrum modifier.......... . . . . . .

5.4.3. Transport Calculations for Coll Assemblies........... . .

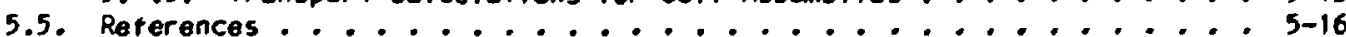

6. STUDIES OF NEUTHKON STREAKING IN GCFR-TYPE CORES: FUEL-LATTICE EXPERIMENT. . 6-1

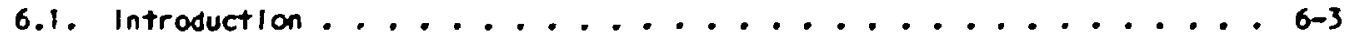

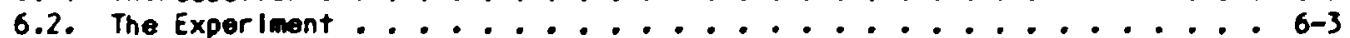

6.3. Anulysis of the Experiment; Comparison of Calculated and

Measured Results ...................... 6-5

5.3.1. Deflnition of jource................... 6- . . . . .

0.3.2. DOT Transport Calculations for Fuel Lattlce. . . . . . . . 6-5

6.3.3. Mante Carlo Transport Calculetions for Fuel Lattice. . . . . 6-9

6.3.4. Sensltivlty Analysls................... 5-10

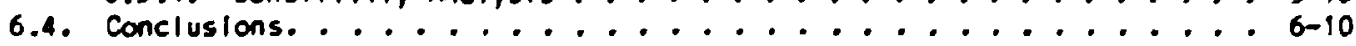

0.5. Feforences........................... 6-11 
7. GCFR GRID-PLATE SHIELD DESIGN CONFIRMATION EXPERIMENT. . . . . . . . . 7-I

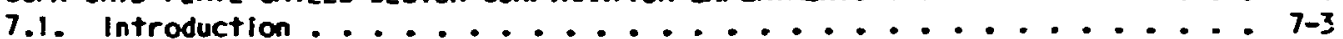

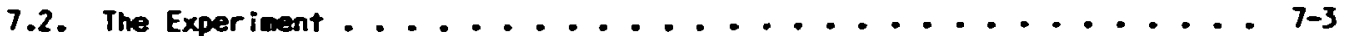

7.3. Design and Preanalysis of the Experiment ............. 7-10

7.4. Analysis of the Exferiment: Comparison of Calculated and

Masured Results ....................... 7-14

7.4.1. Deflinition of Source ................. 7-15

7.4.2. Transport Calculations for Enpty Covity Configuration. . . . . 7-16

7.4.3. Transport Calculations for Fuel-pin Conf Iguration....... 7-18

7.4.4. Transport Calculations for Grid-PIete Shield Configurations. - 7-25

7.4.5. Transport Calculations for Prototypic Grid-Plate Conf : guration - 7-32

7.5. Sumary............................ 7-39

7.5.1. Fuel-Pin Configurations. ............... 7-40

7.5.2. Grid-Plate Shield Corfigurations............. 7-43

7.5.3. Gridflate configuration ................... 7-47

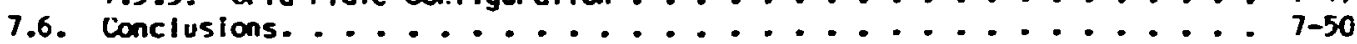

7.7. References ............................... 70

8. GCFR RADIAL BLAKET MD SFIELD INTEGRAL EXPERIMEKT . . . . . . . . . . B-1

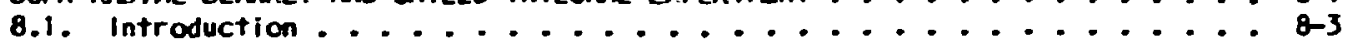

8.2. The Experiment ........................ 8-6

8.3. Preanalysis and Experieiental Design. . . . . . . . . . . . 8-17

8.4. Postanalysis of the Exper iment; Comparison of Calculated anc

Measured Results ....................... 8-25

8.4.1. Definition of Source................. 8-25

8.4.2. Transport Calculations for Spectru Modifier......... 8-25

8.4.3. Transport Calculations for Blanket Configurations. . . . . . 8-27

8.4.4. Transport Calculations for Shield Configurations....... 8-34

8.4.5. Examination of Gama-Ray Spectral Discrepancies. . . . . . . 8-40

8.5. Conciusions. ........................ 845

8.6. References ....................... 8-46

9. GCFR PLENUH SHIELD STULIES: OUTER RADIRL SHIELD +E EROGEMEITY EXPERIMENT. * 9-I

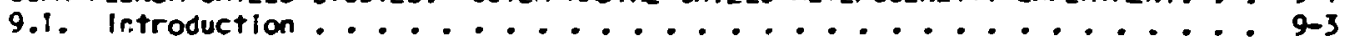

9.2. The Experiment ...................... 9-4

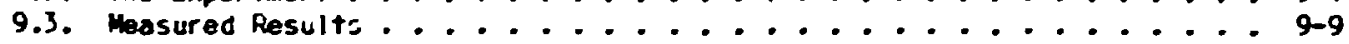

9.3.1. Measurements for Conflgurations 1: Single Slits....... 9-9

9.3.2. Masurements for Configurations 1I: Iron-Lined Sirgle Silits. . 9-11

9.3.3. Measurements for Configurations 11I: Three-SIit Assemblies... 9-11

9.3.4. Measureaents for Configurations iV: Offset SI'ts. . . . . . 9-13

9.4. Comparison of Masured and Calculated Results. ........... 9-16

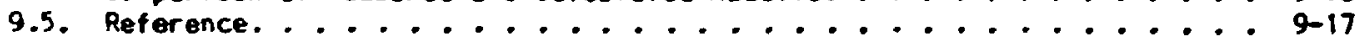

10. GCFR PLEMUM SHIELD STUDIES: EXIT SHIELD EXPERIMENT. ........... 10-1

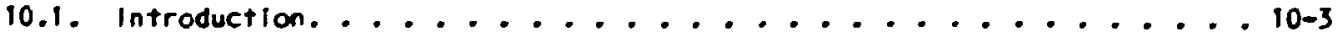

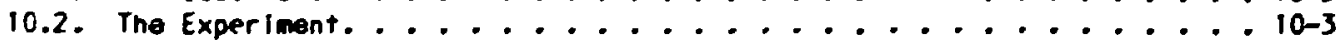

10.3. Analysis of the Experiment; Comparison ut Calculated and

Masured Results.......................... 10-11

10.3.1. Detinition of Source......................... 10-11

10.3.2. Trensport Caiculations for fuel-Pin Contiguratic.1. . . . . 10-12

10.3.3. Transport Calculations for Exit Shleld Configuration .... 10-18

10.3.4. Transport Calculations (or Measuremonts) for Exit Shieid

and Continl Pod ionflgui ztions .............. 10-25

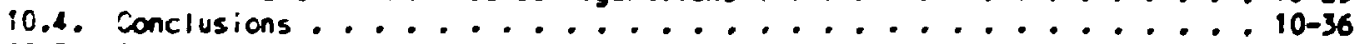

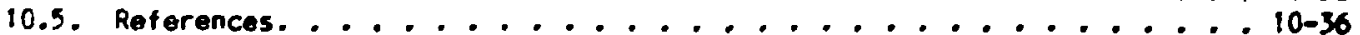




\title{
1. INTPCOUCTION
}

\author{
1.1. Eackground \\ 1.2. OPAL Shielding Analysi: Phllosophy \\ 1.3. The Tower Shlelcing facility \\ 1.4. Organization of Report \\ 1.5. References
}




\subsection{Bnoxeround}

Studi3s of the concept of a Ges-Cooled Fast Breeder Restor (GCFR) using helliu as the coolant were Initiated in the United States In 1962 by the General Atomic Compeny (GNC). In 1963 the Atonic Energy Comission (AEC) began funding the compeny's fuel elewent development work, end within a few vears several U.5. utillities were supporting GAC In a broed GCFR progra. BY 1975 the total number of participating utllitles had Increased to 57, and 70 rural electric cooperatives and three European itility compenles had Jolned the effort.

The tirst conceptuai design of a 300-mim(e) GCFR demonstration plant was completed in 1970 (ref. I) and vas followed by Intensive studles of the varlous systens and components essential to the final design. The utllity-supported progra of Gaz emphasized work on 1,e overall plant design, IIcensIng, and sitIng, whlle the NEC-supported progra Included, In oddition to ti.e fuel element work, studies on reactor physics and component development. AEC also supported a auber of other ECFR prograns - at A gonne Nat onal Laboratory (ML) and Oak RIdge Matlonal Laboratory (ORNL), as well as at other labcratorles - In the ras of core flow loop testing, critical experiments, Irradiation tests, satety experimants, shlelding andysis. etc. This support was continwed by the Energy Rasearch and Development Adminlistration (ERDA) and Iater by the Depertwent of Enorgy (DOE).

Inspfer os was prectical, the cesign of the GCFR demonstration plant was basel Gr a minimua extropolation of the componont technolcgy for the High-Temperature Ges-Cooled Reactor (HTGR) and on the physics and fuel element technology of the LIquid Motal Fast Bresdir Poocto- (LABR). BY 1974, odvances In the HTGR component technology, together wth dotalled dasign aid safety reviews and erchitect-anglnew studies for the CCFR plant 1+self, had resulted ir major changes to the 1970 dos!gn and a maw dosign fer the demonstration plant was releaced (raf. 2 ).

As port of Its GCFR work, ORAl wes asked by GAC to revlew the shielding system of the new GCFR design and to Identify are?s ot concern. The concerns were subsequently discused with GAC, wheroupon GPC requested thet OAll delelop a shlelding progres thet would elther confirm the deslgn or polnt out regions in which problens existed. 
Basically. Oon proposed that the shielding for the EcrR be andyzed in a progra sialler to one that hed been conducted for the Fast FI wox Test Faclility (FFIf) (rof. 3). By cerly

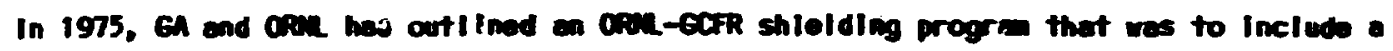
serles of radiotion transport calculations for speciflic reglons of the GCR system. In addition, the progre wes to Include a serles of supporting experinents and thelr anelyses.

When the U.S. ECrR progra wes ceacelled In 1960, six of elght plannec coper Inonts had been coupleted. Becouse auch of the informotion gainod from these cacer inats ead their analyses is goneric and therefore applicable to other reactor systems, it was felt that a review of the expariments in a single document would be of consicerable velos: This report presents ther review.

\subsection{Coar SHELOIIG anLYSIS PHILOSOPHY}

Inherent In the shlelding anaivsis approach used by Oowl Is the experinomtal verifleation of the colculational mern.as that are to be epplled in the enalysis of a particular reactor shlelding system. As a result of an earlier lengthy wathods development progran. Iergely supported by the UWER progran and the Defense Nuclear kency, when the GCFR shlelding progren ves initiated coes aiready had on hend two powerful computer codes for calculating radiotion transport, and both had undergone exper Inentel validation for application to other reator-shicid systems. One code wes the discrete ordinates transport code DOT (ref. 4) and the other was the monte Carlo code MDRSE (ref. 5).

menever oot or mDRse is epplled to a naw system, however, o certoin enount of revallidation is necessery. especialiy if new celculational techniques ere to be developed and Introduced in the codes for calculetions of reactor and/or shield rea! ons thet differ signiflcentiv froe those In proviously aneigzed systums. In the velldetiun experiments the reglon of concern is nocked up and mesuremonts ere nade of the penetrotion of rediations through It. The experiments ere then enelyzed with the sene calculatlonel enthods thet heve ben or ere to be epplied to the ectuel reactor system. Agrcument between the mesured and celculeted results ensure thet the nothods cen be applied with confldence to sialler reglont in the reactor. When, on oceselon, eqrenent is not 
reeched, the difference betwan the mosered and calculeted reselts is used es a bles factor to Introduce conservatisa In the reactor design.

In the cese of the GCFR, several experilents vere decued necessery to test the appilication of the transport nathods to a billencooled system, prinurly bocense the

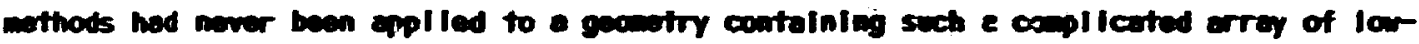

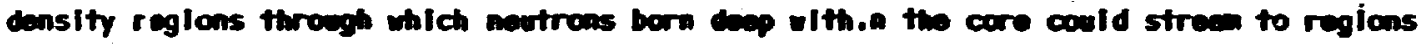
outslde the core. Predlcting the streaing was expected to severely test the wotiack end

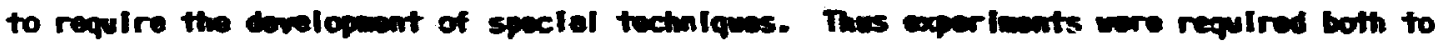
ald In the development of the twchalgens and to thest thea.

\subsection{The TOUR SHELIIS FRCILITY}

For over 20 vers the princlpel expriantel shlelding feclitity of ain hes been the Tarer Shlelding Facllity (TSF).- The feclilty wes origlas!ly bollt for studles of radiotion interections within the atwosphere (for the Alrcreft Mrclear Propulsion Progral and wes deslgned so that a reccor could be sespanded betwen four 315-ft-hlgh twers - hence Its naes. For current shlelding experieants, however, the faclilty's reactor, called the Tower Shielding Ractor II (TSB-II), recalas on the ground and Is

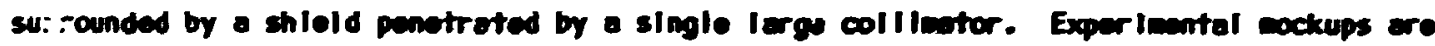

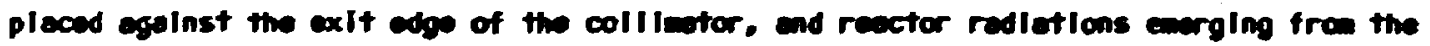

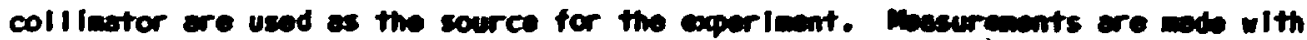
detectors placed coth behind end within the experimental conflgurations. A view of the shlelded TSR-II of the TSF site is shom in In FIg. I.1.

\subsection{Cosmization of REsoit}

The six GCTR experimeats perforned es port of this proge ere described here Ix Chepters 5 through 10. By wy of Introduction to the experimats, the perticuler ectR shleld reglons of concern ere Identifled in Chapter 2, and the experimental and calculational technlques ore deseribed briefly in Chepters 3 and 4 respectively. 


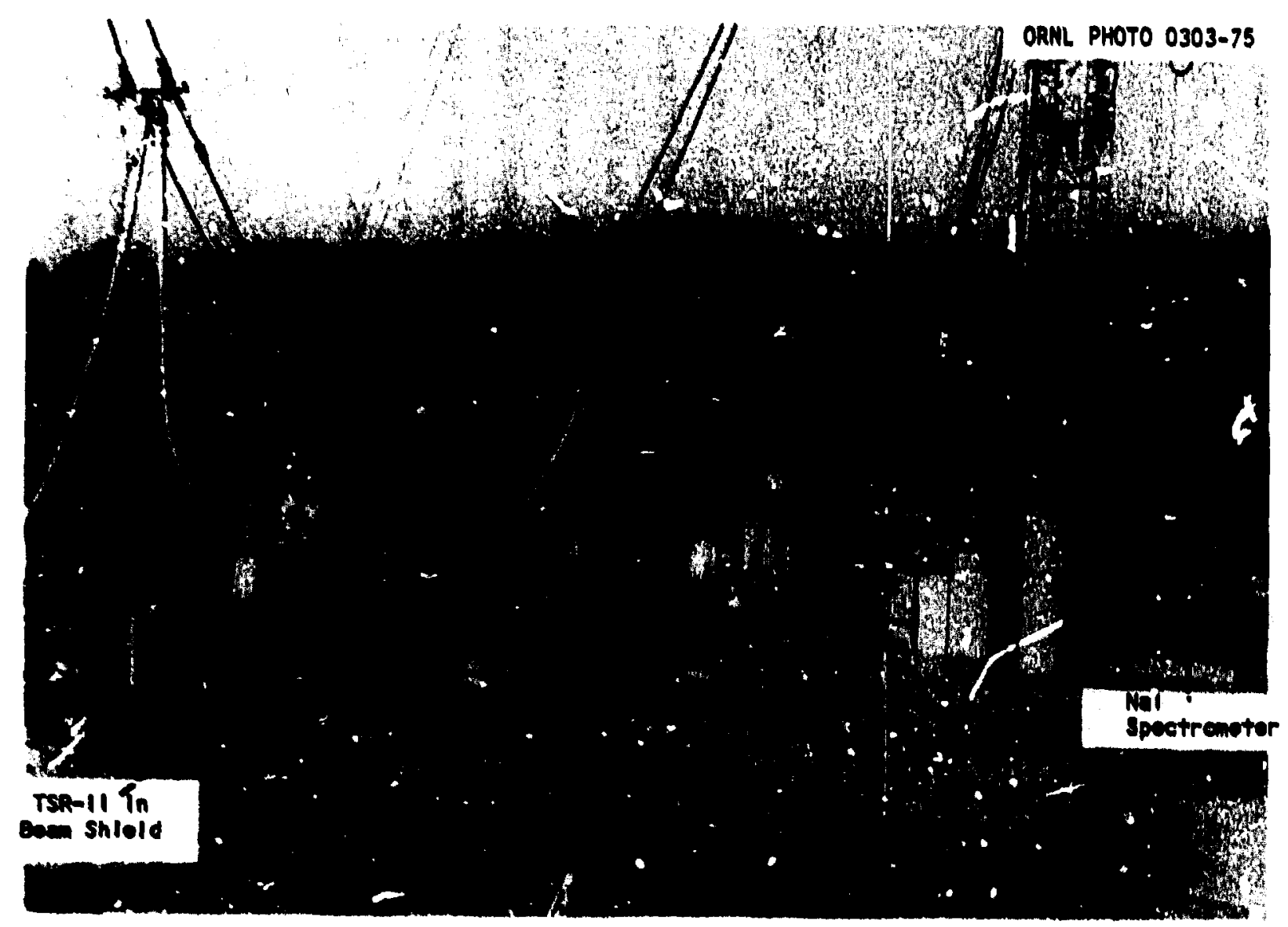

F1g. 1.1. The Tower Shlelding Fecllity. Exlt edge of co,llmator through TSA-11 beam shlold shown st loft. (Notes ceconetry of reactor and shleld :s shown In FIg. 5,3, page 5-12.) 


\subsection{REFERENCES}

1. Gas-Ccoled Fast Breeder Reactor Lemonstration PIant Muclear Stean Supply System." Eulf General Atoulc, Report ER-10064 (Noj 15, 1970).

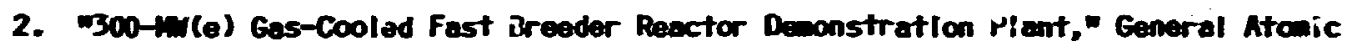
Compeny, Report GA-A13045 (July 15, 1974)

3. Lorraine S. wbott, F. R. Hynatt, W. W. Engle, Jr., and F. J. Wuckenthaler, Revier of Col Rodiation Shlelding Analyses of the Fast Flux Test Fecillty Raactor," Crul5027 (July 1975): Lorraine S. Abbott, F. R. Mynatt, W. W. Engle, Jr., and kergaret B. Enatt, Meviow of Din Radiotion Shielding Anilyses of the Fast fiux Test Facility neactor (1975-1976), = 019u-5166 (June 1976).

4. F. R. Mynatt, F. J. Muckenthaler, and P. N. Stevens, Davolopment of Two-OImens Ional ni screte Ordinates Transport Theory for Radiation Shlelding, "Coaputing Technology Center, USC-ND, CTC-INF-952 (1969); W. A. Rhoedes and F. R. Mynatt, WThe DOT-III Two-Dimensional Discrete Ordinates Transport Code," Caul-Th-4280 (Sept.. 1973); W. A. Rhoedes, D. B. Simpson, R. L. Childs, and W. W. Engle, Jr., whe DOT-IV TroDimenslonal Discrete Ordinates Transport Code with Space-Dependent Mesh and Quadrature," Coell/m-6529 (January 1979); W. A. Rhoodes and R. L. ChIIds, "An Updated Versirn of the DOT-A One- and Tro-Dimenslonal Neution/Photon Transport Code," ORal5851 (II, roview).

5. E. A. Straker, P. M. Steveris, D. C. Irving, and V. R. Cain, The MORSE Cose - A Multigroup Noutron and fama-Ray Monte Corlo Transpat Code," OpML-4585 (1970); M. B.

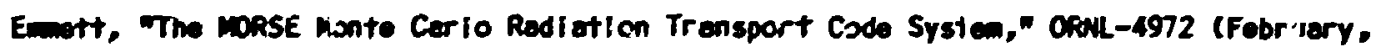
19751 . 
$0^{2}$

2. THE GAS COOLED FAST BREEDER REACTOR

2.1. Priocipal Feetures of the Kucleer Steen Supply Systen 2.2. Practor shlelding

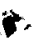




\section{1. PRINCIPAL FEATUPES OF THE MUCLEAR STEAM SUPPLY SYSTER}

The 1974 conceot of the nucleer stee supply system for the 300-min(e) ecth cencristration plent is depleted in Figs. 2.1 and 2.2. In this design the reactor core consisted of a 39.2-In.-high fueled region contalnod within 265 fwal and blentet elements. The elements were hexagonal in cross section 16.6 In. $x$ oss the flats of the hesagon) and had an overall length of $11.5 \mathrm{ft}$. A uplape feature of this design wes the suspension of the ful and blanket elements tran a 24-ia.-thick stainiess stuel grid plete obove the core.

A standerd element contelned 270 feel rods In efrich the fleled section wis comprised

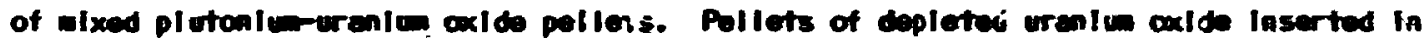
each end of the reds fornd the axial blanket abowe and belon the core. Radial blenkat el sments surrounding the furel elements conteined nellets of urenive or thorive axide.

The cooling system In the denstrotion plent design consisted of a ihroo-loop maln hellin cooling system tacked up by a thrue-loop core euxlliary cool Ing systen. The heilun flow vis doumerd through the core end then upverd around the ourtside of the core therral st.lelding and out to the sted generator covity. The flow continued cownuard through the steen generator, Deck up eround the outslde of the stea generetor to the win hellun circuletors, and then beck to the top of the core cevity to bugln the cycle agein. The coolent Inlet temperature vas ebout $300^{\circ} \mathrm{C}$ and the outlet temperature wos $550^{\circ} \mathrm{r}$

The reactor. Its cool Ing syster, and its euxillary systems were all contel red with in - prestressed concrete resctor vessel (PCRV) that hed an outslde dianter of 64 ft and o helght of $80.5 \mathrm{ft}$. The rector cavity within the PCov we $20.5 \mathrm{ft}$ in dianter and 41.8 ft in helght. The PCay technology was besed on thet developed for the PCRY of the fort St. Yraln Resctor, wich is the only HTER In ooerotion In tho U.S. Cortside the U.S., exper ience with PCWVs has bew coxtensive.)

\subsection{REACTOR SHIELOIMG}

The or Imery function of the reector shlelding in the GCrR design vas to protect the

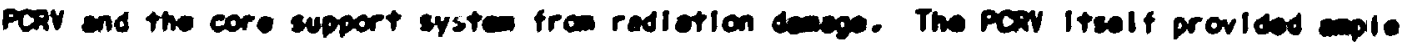




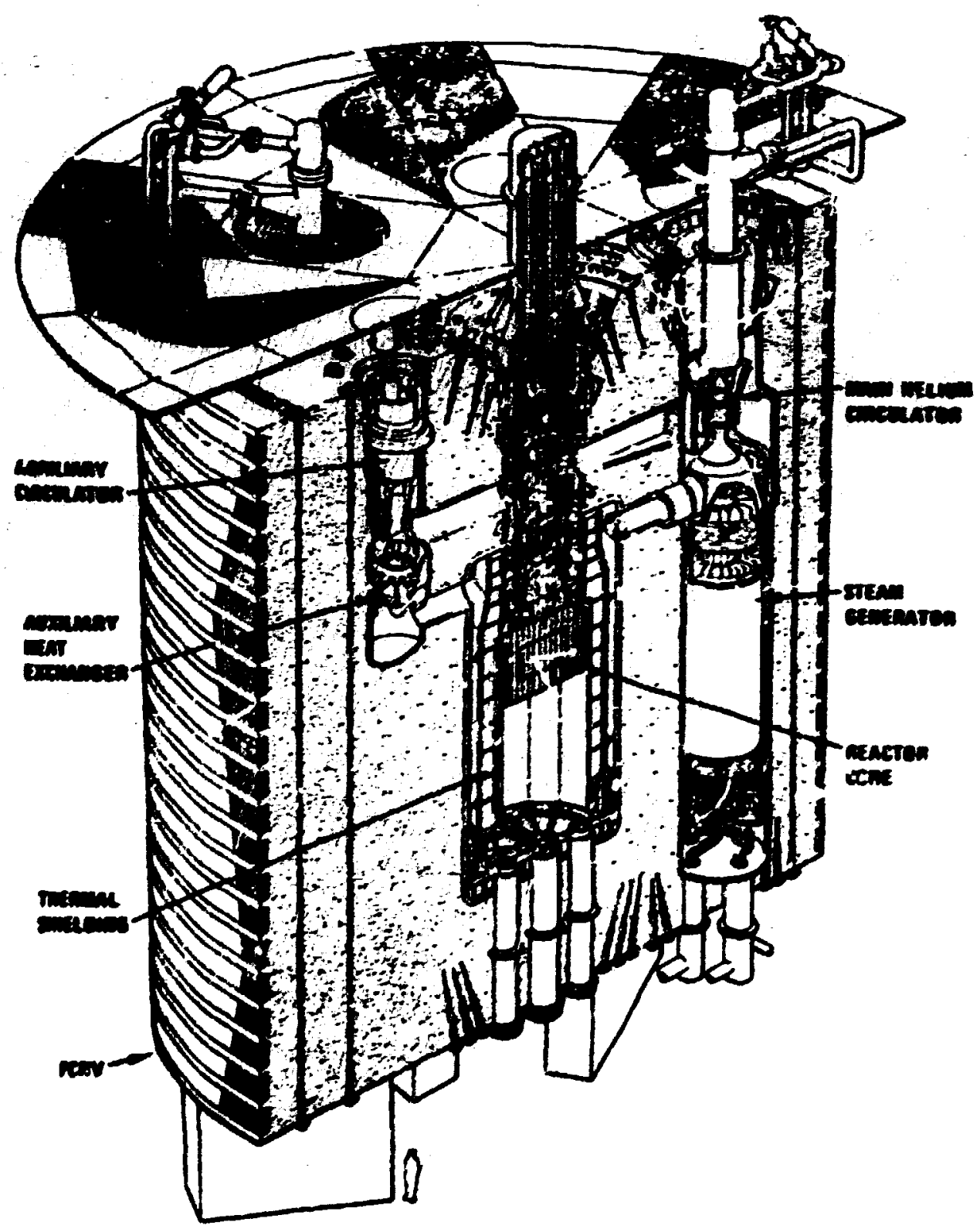

Fig. 2.1. Muclaer Stwen Supply System for the 300-Am(o) ECFR Demonstristion Plant (Dounflow Desion). 


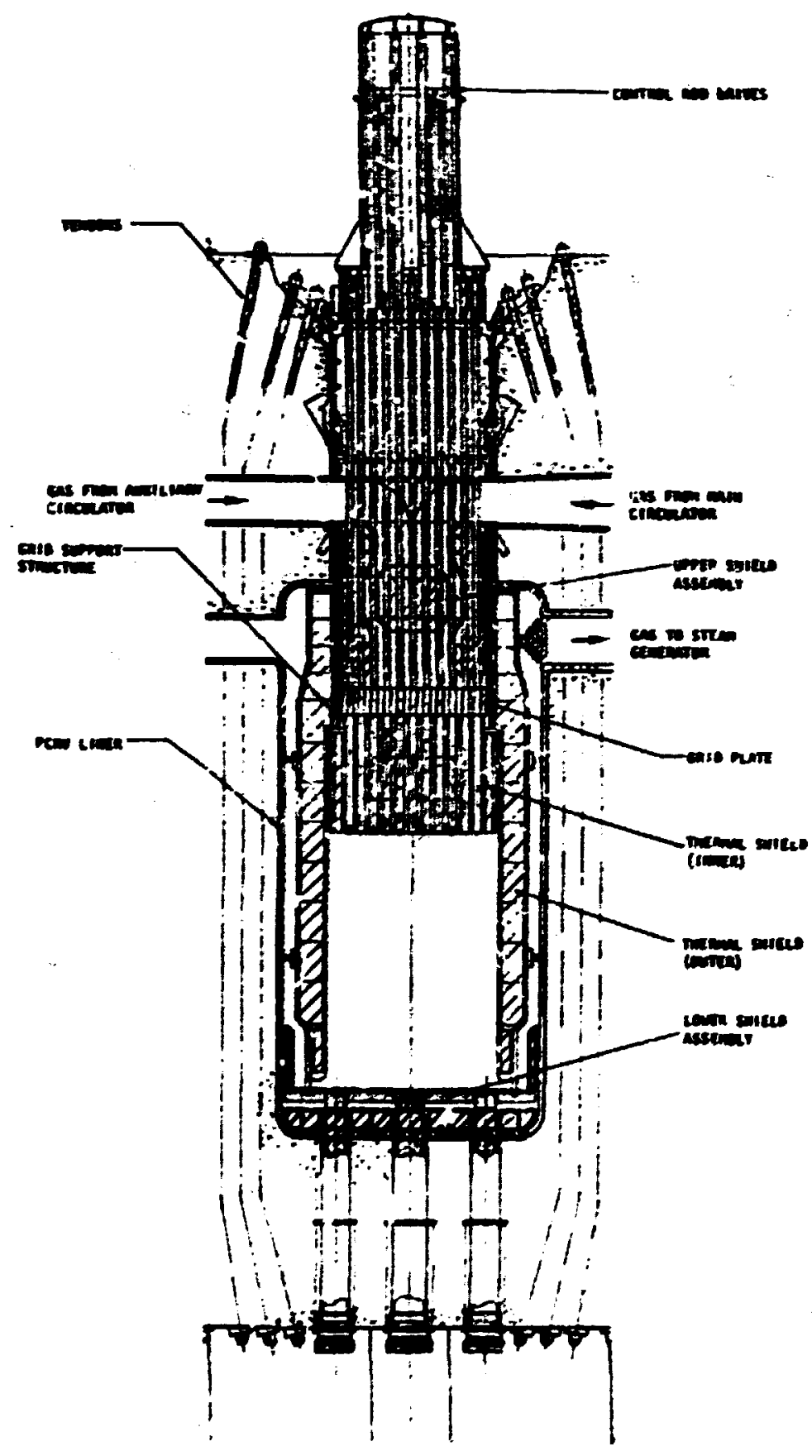

Fig. 2.2. Vertical Section Through Rasctor Covity (Downflou Design). 
blclogical shlelding. Also, the baile coolent woold not become radloective or dissolve and cerry corrosion products, which would reduce the shlelding requirenests for ainfenance on the sted gemerators. circuletors, etc.

As has baen polnted oer In Cianter 1, the passegaweys required for the hal Iu coolant to flow through the core provided peths along hick mentrons could strear Felatively onimibited to the outslde edges of the core. And with the ECFR beling a fast reactor, the flures of hIgh-energy neutrons prodeced in tixe scre could be expected to be considerabiy higher then the fl wus produced In. fherail reactor. Ilus the ECFR design. Included a numbr of shield regions ingodiately around the core.

The first sileld studied aith a supporting experinomt was the grid-plate shleld. As shem In Fig. 2.2, In the I974 GCFR design the grid plate supported the core from above. The grid-plate shleid consisted of ceterial edded In the upper ends of the fuel elements. When the TSF "grid-plate shleld design confirmetion experimente vas performed In January. 1977. the GCFR design In which the grid plate was abova the core still prevalled: inovever, after the exper lwant was performad, the GCFR wes redeslgned with the hellum colent fiowing upws:d rather than downard and the reactor grid plate positioned belou the cort ra'her than above it. The design of the grid plate onc the fuel alements reasined essentialiy unchanged, however, und thus the TSF exper Iment was stIII pertinent to the study of the grid-plate shield, which then reslded in the lower ends of the eienents. A sketch of the flual (upflow) full element I: shown in FIg. 2.3, and the Iocation of the grir,pplate shleld with respect to other sections of the GCFR shielding is shown in Fig. 2.4.

The grid-plate shield confirmation experiment is cescribed in Chepter 7 . Wille it comprised the flrst "shlelding" experiment in the ECFR shleld andysis progran, it weri precedec by two other exceriments supporting the development of technlquas for colculeting the streasing of neutrons fram the core. Since trensport calculations for on extreme ceometry such as that represented by the GCFR core had not been performed, covlsing techniques for determining the fluxee emerging from the rore was prerequlsite to onalyzing the shlelds. These prel iminary experiments are dascribed in Chapters 5 and 6. 


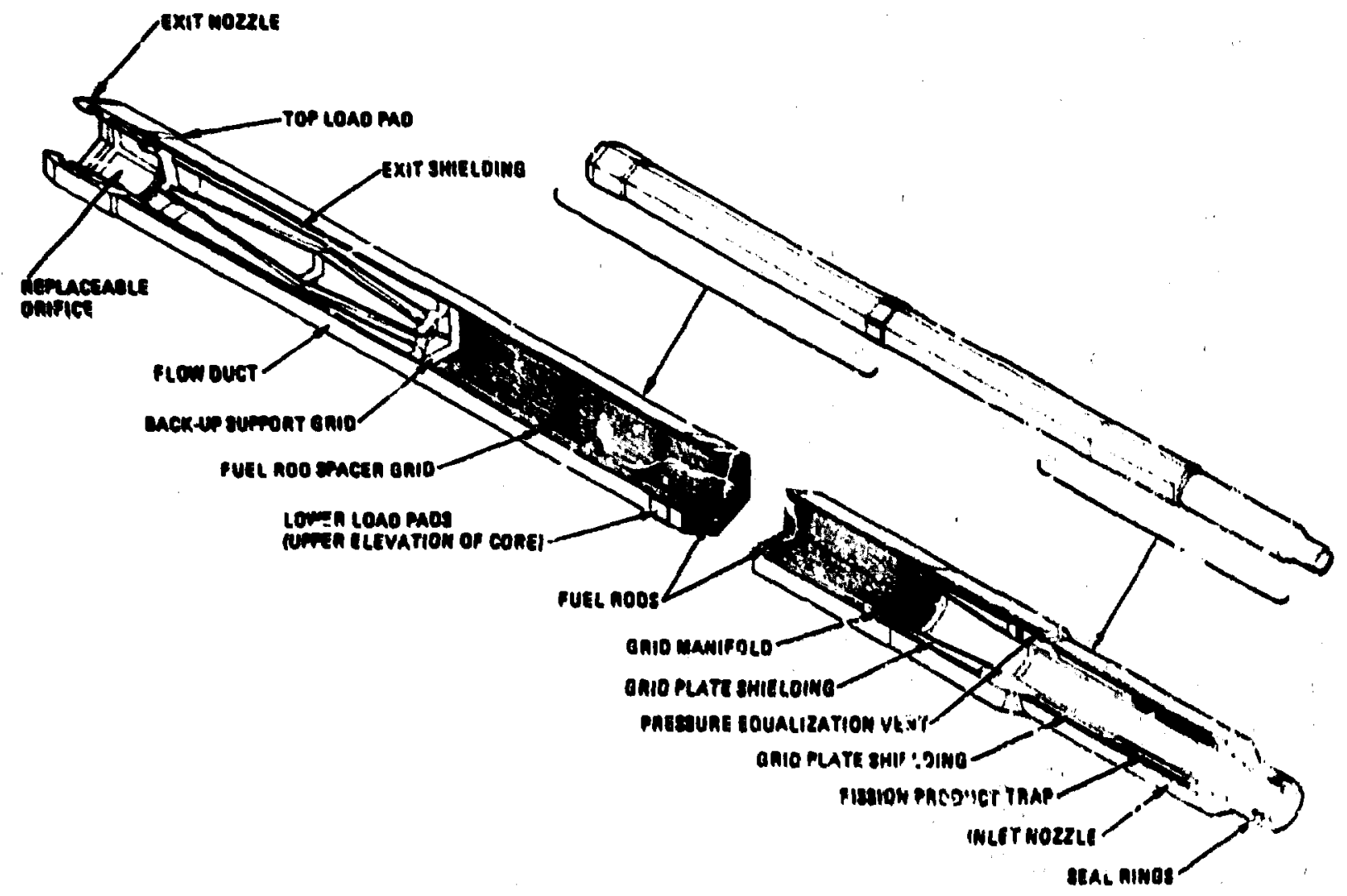

Flg. 2.3. GCFR Upflon Fuel Assembly. 


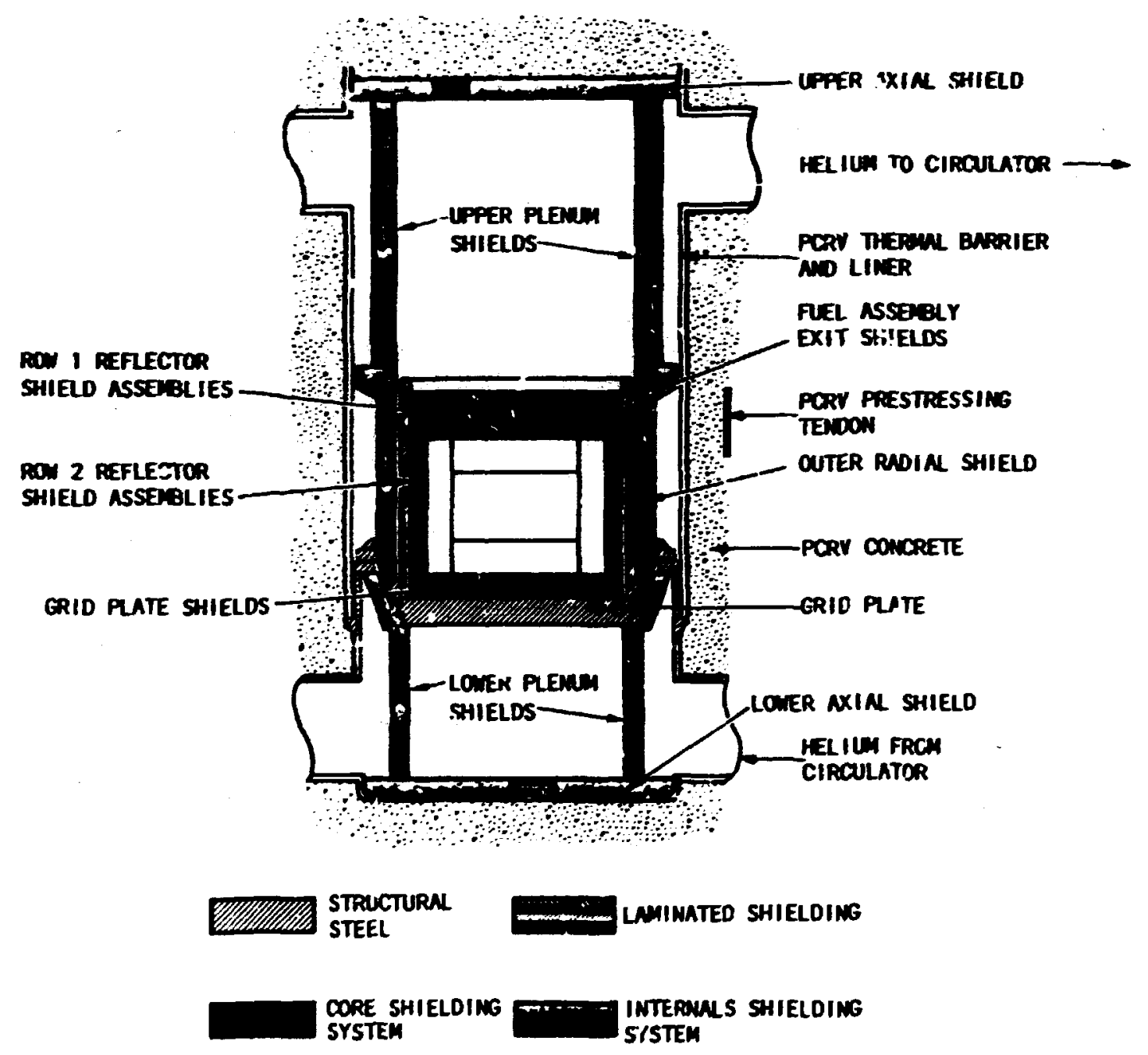

Fig. 2.4. GCFR Shielding System Components (Upflow Design). 
The second section of the resctor shield considered in the progran wes the radial shield protecting the PCW. As noted In FIg- 2.4, the redial shield consists of anter shield, which wes permenent, and an inger shield, which was resovble. ihe experienert and calculations for this shield are discussed in Chapter 6.

The radiel shield stody reported in Chepter 3 focused on the gross attenuation of rediation thrugh solld shlelds using the sere materials as are called for in the GCFR redial shield dssign. In the actual design the oster racial shield would consist of abutfing blocks of meterial, and the question arese es to tha extsat of strecalin: thet aght occur between the blocks. The experlaent describeo in Chapter 9 was performed to Investigate this effect.

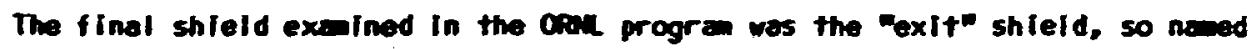
becouse it was Installed in the helium exit end of. the fuel elements to reduce the fluxes within the upper plenum. The locetion of this shielding in the fuel eicment cen be seen In the upper left of FIg. 2.3 (see also Flg. 2.4). The exit shleld experiment is describad In Chapter 10.

Two additional experizents had been planned to investigate the adequacy of the shields surrounding the plenum reglons, but the GCFR progres was cancelled before they could be performed. 


\section{TSF EXPERIMERTML TECHIQYES}

\subsection{Detector Systems}

3.1.1. Herrayat Button

3.1.2. VE-213 spactrameter

3.1.3. Bonener Batls

3.1.4. Hyt ogen Counter

3.1.5. Then molninescent Dosimoter (TL)

3.2. Aualysis of Exper Imental Errors

3.3. Asterences 


\subsection{DETECTOR SYSTES}

During the years of expe.-Inentation at the Tover Stildiding Fecility (TSF), several different detector systems heve beas successfully adapted to massurenents of the Intrensities and energles of the neutrons and gemerroy flel ds encountored in exper Imonts

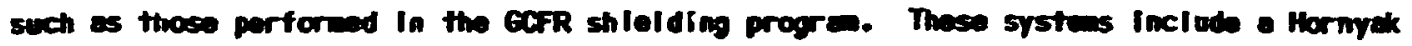
button doslmeter, en IE-213 spectranoter. Bonner balls, a hydrogen counter, on Mal spectrometer. and thermol winescent dosibeters (TD). Brlef descriptions of the detectors used dur Ing the ECFR exper lants are gl ien be'ow. In general, this Information has been IIfted from earller reports (refs. I-3).

\subsubsection{Hornyek Button}

The Harnyak button has a response to neutrons that closely approuthes that of a fast-nautron dosineter. Oescribed in detoll el sembere (ref. 4), the detecto consists of a homogeneous mixture of fine Iuclte and zinc sulfide crystals formed into a button. When exposed to fast meutrons, the button ects as a sciatlilator whose pulses ore magnifled by a photaultipligr tube. For these experinents, the betton was $0.635 \mathrm{~cm}$ in di aneter and $0.159 \mathrm{~cm}$ thirk, and It was mounted on an Rex photonultipller tube.

The cal Ibration procedure for the Hornyak button es used in the GCFR experiments consisted of first exposing the scintillator to a 2-R/h gano-rey dose rate and adjusting the electronic gain to obtaln a prescribed count rate for a pulsetholght satting of $0.6 \mathrm{~V}$

(fexs $=060)$. The button was then exposed to a known intensity ${ }^{252}$ ci noutron source and a count rote was cotalned for a PHS of 350. Callbroting of the higher PHS was necessery in order to blas egalast the maxime pulse helght that would be reached from gamoror Induced pul ses during the exper lenents. Callbretlons end neosurcanots were obtalmed of this pus even though for soms of the mesesurements the megnitude of the gemmerey flux wes conslderably lower.

\subsubsection{E-213 spectranter}

The RE-213 spectranter (ref. 5) Is used primer Ily to obtaln the energy spectre of neutrons In the range fram $000 \mathrm{kol}$ to $15 \mathrm{kgV}$. In princlple, It cen also be epplled as a 
genorroy spectroneter; however. to dote this hes not been dene very successfully at the TSF.

The sensitive component of the ME-213 spectraneter is a sall cyllonder of ME-213

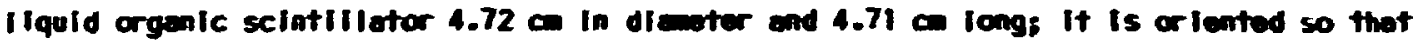
the neutrons are incident primarily on Its curved surfece. IE-213 is used os a compromise betwean sensitivity and resolution and beceuse of its relativaly isotropic response. A 14-grode phrstaultiplier tube is optlicaliy coupled to the selintli lator.

The pulses fice the rE-213 scintillator doe to neutron and gemo-roy irteractions hace short decoy time plus a longer component whose megnitude is grater for the proton recoll then for the electron, assueing equal Initiating energles. Through Integration and duble differentlation, blpolar pulses are uroduced from the meutron-induced proton events and game-roy-Inducod electron events that cross the bese I ine of different times, Independent of amplitude. This separation in time provides the cepebility for electronically routing IInear pulses fro esch of the events into separate mewory locations in the computer. Thus both neutron and gama-ray spectra ore obtalned. Tho rastiting pulso-halght distributions are then fea into the computer code (FFRD) ro obtain the energy spectra.

\subsubsection{Bonner Balls}

A Bonner bell detector asasures en Integral of the noutron energy flu: wolghted by the energy-dependent response function for thet bell (ref. 6). The detection dovice In a Bonner boll consists of a 5,1-co-dien spherical proportional counter filled with approximately $1 / 2$ atm of $\mathrm{BF}_{3}$ enrlched to 985 in 10 $\mathrm{B}$. The counter is encloced in verlous thicknesses of polyethylene shel is, the thleknoss determining the cutoff energles of the meutrons dotected. In all ceses the polvethylene shell is covered alth a 30-all thickness of cadilum to suppress the response of the detector to Incldent thermal noutrons. When this system Is used, neacuremante made with the Bf 3 counter bere and cedmlum-covered (no polyethylene) are usuelly included in the serles. 


\subsubsection{Hrorogen Counter}

The irdrogen comater is used for mentron spectral enesurenonts, uswally In the

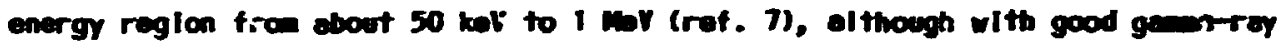
discripinetion neutrons with lower energies cas be detocted. The conorrer consists of a mydrogan-filled stainless steal sphere wth a tungsten wire loceted alos ase of Its. diemeters, the sphare and wire ecting as a cathode and anodo respectively. A sall abpo source on the aldpolnt of the wires of the center of the sphere is a calibration source. The counter Is flliled to different pressures (1, 3, and 10 atw) with indrogen ges. Weutrons entering the counter suffer scottering collislons with irdogien nuclel and produce recoll protions in the gas. Eech proton then ceuses Ionlzation, and the resulting electrons are collected on the positively chwrged anode. The encror of the recol: proton is ceterninod from the anount of cherge collected. Since the seattering of nonomergeric meutrons by infrogen nuclel produces a range of recoll-proton energles from zerc to the full neutros energy, a detallod andysis is requlrad to obtain an energy spectru from a polyenergetic neutron source. Pulse-helght dete fran the iryogen counter are unfoldad with a computer code (SFEC-A).

\subsubsection{Thenx' ininescen:- Dosineter (TLO)}

Thermol uminescent dosfimeters are usad to measure the deposition of gamo-roy energy within a shield (rof. 8). The system is besed on comerclally ovalleble chlps of ${ }^{7}$ LIenrlched LIF and anganose-ectIvated Cof 2" Incident gamo rays Impert energy to the orbital electrons essocleted with the lona acking up the crystal structure, resulting in the electrons bing ejected from and not inmedetely recoptured by the lons.

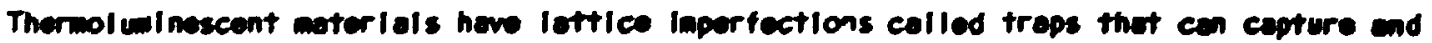
tempor orily hold the energetle electrons. If edditional eneroy is imperted to tho trepped electrons by nesting. the trep will releace the elcctrons end under certain conditions the excess kinetic enorgy of tho electron will be cultted as IIght. Inder cer ofully controlied hasting conditions, a cherecteristic IIght output vereus tempercture "glow curven is producad. Through a celibretion proceduie, the enount of intensity of the light ascoclated with the glow curve cen be reletes to the Intensity of the rediation 
fleld endor the essocleted energy deposition by that iadiation at the exposere position of the therwoluinescent werterlal.

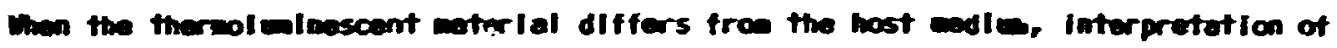
the $\mathrm{NO}$ responses cequires spectral correction fectors thet are deterinined andyticaliy.

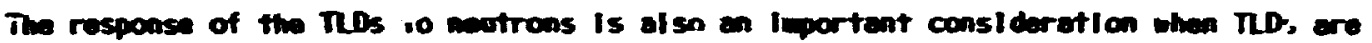
appiled in reactor shlelds, wilch are usualif sebjected to charecteristically high neutronto-gane retios. Correction factors for the TSF MDs are calculated fro ross-section sets and other beslc date.

\subsection{MuLrsis of EXPERIUETML ERPORS}

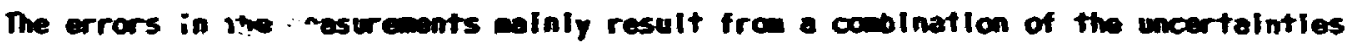
In the reactor pomer deterwination, detector callbratlons, count-rate statistics, detocror positioning, conflguration gocmetry and fabrlcat'on tolerances, end exposure of the exper Inontel conf Igurations to the wather. Of the se, th. of fects due to changes In the weother are the least understood and are probably ceyond simple estiation. The configurations are naralily exposed to the veathar and the uncertainty in the masurements Is lergely due to the variabls acounts of nolsture penetrating the spoce between the slabs forming the conflguretions. Sane uncertainty is also Introduced oy water absorbed within the waterla, placed around the slabs to Inhiblt background contribution:

A slgnificant source of error In the experiment usually lles in the deternination of the reactor pemer. The power level for esch abesurement is determinad fram the outputs of two fission chmbers located in the reactor shleld along the reactor centeriline. These detectors are cellbrated dally and are perlodically compared with gold-foll activetion mesurements of the sam locations. During any one datector troverse in a given dey, the varietion In the reactor power os Indicated by the monitors alght be orily - few percent. However. over a spen of evveral months of reactor oparation, the monitors wey Indlcete that the power level has verled os much as 58 fram the level indlcated by the reactor control chabers. These verlations wey reflect the degres of rellablitity of the monitors or they moy repreasent a real chenge in the actual power output. 
Positioning the detactors with respect to the configuration is normaliy critical only wen mesurements ere exde very close th the exper Imental conflguration where the radiation field verles significantly with the location. It is estinated that during a radial traverse behind a configuration the detector position alght oscillate sereral allibatars un each side of a given ilne, which could affect the date by a fen percent. At a distance of $30 \mathrm{~cm}$ behind a configuration, however, where many masuraments are made; the positioning error would be negliglbie.

Configaration fabrication tolerances vary to scise extent with the experiment, and count-rate statistics and callibration factors are un lque to each detector system. For the Hornyak button, It is not uncommon to have a $\$ 56$ ver!ation in the cellibration factor. when combined with the errors from the reactor power determination, positioning, and counting statistics, the estinated standard error for the Hornyak button Is \pm 104 .

For the ME-213 spectrameter, counting statistics and unfolding errors are included In the unscrambling of the pulse-helght spectra ueIng the FERO code, with the resultant flux expressed in terms of lower and upper IIalts that represent a $68 \%$ confldence Interval. Siallar errors are expressed In the tabular data for the hydrogen counter masurements unfolded with SPEC-4. In neIther case, however, Is the error In the reactor power determinatlix? !.cluded in these values.

For the Bonner balls, the stetistical error In the detector count rates is usually kept below 1 to 25 by malntalning an adequate court rate. Calibrations over on exper Inental perlod Indlcate about a 3 to 48 varlat!on. When the error In the reactor pover determination Is Includad, the error In the Bonner ball data averages \pm 5.

In the case of TLD mesurcenents, en attempt is made to calculate the error for each chip locetion In the conflguration. The reliablilty of the results depends on many things, the most common beling the determination oi the welghts of the chips and of their reletive censitivities to radietion, precelibration of the TLD reader end the subseq. went calibretion of the chips, the chenges in censitivity of the chips with use, the abise suffered by the chips In hending, and exposure conditions. With established procadures used throughout the experiment to minlalze these fectors, the estimeted error, excluding reactor pover varlations, usually falls within $\pm 5 \%$. 


\subsection{REFEREMCES}

1. F. J. Muckenthaler. J. L. Mull, and J. J. Monning, GecrR PIenue Shield Design Shleid Heterogenelty Experiment, " Oan/TH-7714 (Moy, I9ai).

2. F. J. Muckenthaler, J. L. Hull, and J. J. Monning, GecrR Plenue Shield Design - Exit Shleld Experiment, orulma-7715 (Mor. 1981).

3. C. E. CII,frrd, F. J. Muckenthaler, F. R. Mynatt, and L. S. Abbott, "Study of Moutron

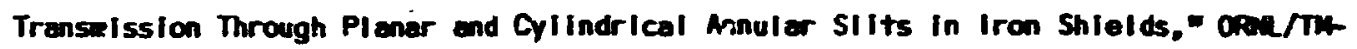
3513 (September, 9980$)$.

4. F. 1. Muckenthaler. In Appl Ied Muclear Physics Division Amual Peport for Per Iod Ending Septcaber 10, 1956," opal-2081, p. 199.

5. V. V. Verbinskl et al.. Mallibretion of an Organic Scintlllator for Noutron Spectiranetry," Oank-n4-2183 (1968).

6. R. L. Bramblett, R, I. Ex!rg, and T. W. Bonner, Mucl. Insti. Moth. 9, 1 (1960); W. R. Burrus, In Neutron Phys. Div. Ann. Prog. Rep. Sept. 1, 1962, " Opal-3360, p. 296; 5. K. Mehta, in Meutron Phys. Div. Ann. Prog. Rep. Aug. 1, 1964," Opal-3714, p. 80.

7. An ORNL version of a Benjamin-type proportional counter: see P. W. Benjali , C. P. Kemshall, and J. Redfsarn, Mucl. Instr. Muth. 50, ?7 (1968); see also, R. G. Grat, The Iaplementation and Calibration of aenjealn-Type Neutron Spectroneter for Energles Below $1.5 \mathrm{MeV}, "$ University of Tennessee Doctoral Dissertation, 1969.

8. C. E. CIIfford, F. J. Muckenthaler, Wu Yoon, P. N. Stevens et al .. WTi.enoluiuinescent Dosimeter Masurements of Radiation Kaeting In Sodium and Stainiess Steal Shieids," OXNL-5329 (to be published). 


\subsection{The mular mausport cones}

As noted in Chapter 1. the cove shielding enalysis cithods are based on two wajor computar codes: the discrete ordinates transport code oot (ref. I) and the horte Cerlo Ironsport code wase (ref. 2). These codes use two dlfferent approches for solving the

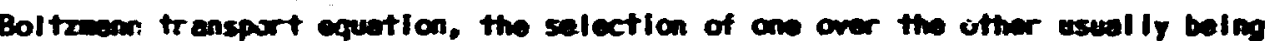
deternined by the gocustry of the shield region ro be calculated. For reesons thet.wlll be apperent frow the folloulang discussion. the Dot code us used for wost of the analyses of the TSF GCFR exper Iments.

In adition to DoT and mase, the MISU discrete ordinates cods (ref. 3) was used frequatiy In prel leinary analyses beceuse of the cost sovings rolative to bor or mise.

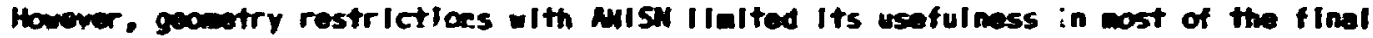
analyses.

4.1. The OIscrete Ordinates Codes DoT and AISN

The discrete ordinates mothod is a numerical technlque that simultancousiy vields higily differential results for the entire systen beling calculated. In the colculation, the syster Is dividad Into finite spece calls and the calculation alatalns a bel ance sotwean perticle galns and loses for exch space call. With the origin (source) of the perticles speclified and the boundary conditlons set, the calculation begl is with the highast energy group and smeps through al l lower energy groups and all spece cel Is In the syste for oll particle directions. Several sweops (Iterations) are required before the results converge ro give the number of particles fran the sourca's high-energy group that haw entered each spece cell, topether with thelr resulting energles and directions.

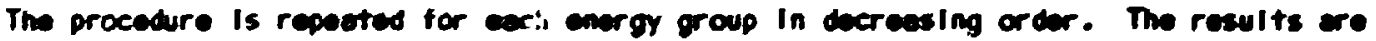
presentec for spece polnts loceted of the centers of the spere cells and ere taken to be the meas of the number of perticles within the given energy group ef coposing feces of the cells.

The ajor shortcaling of the oot discrete ordinates cods (ref. 1) is that it is

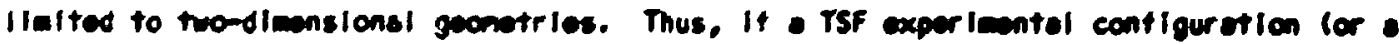

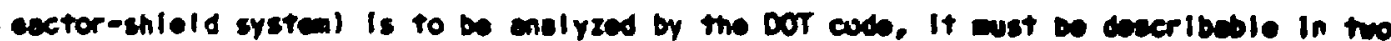




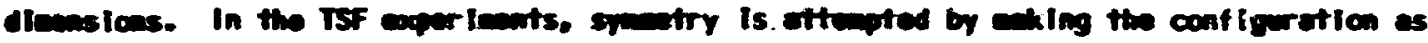

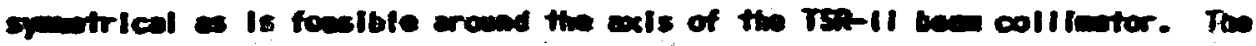

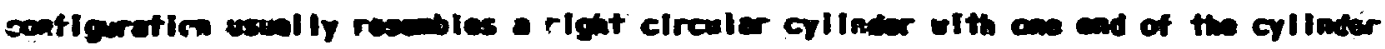

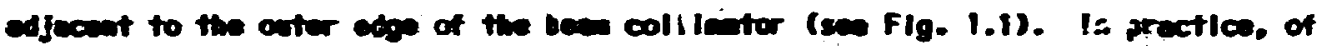

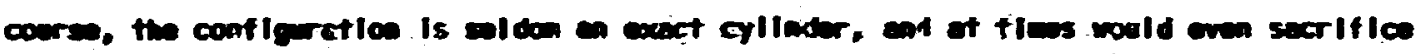

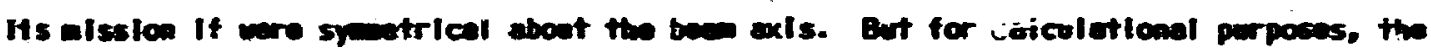

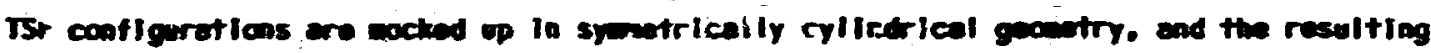
calcaleted flows are symetrical arcuis the axis of the cyllader.

Another probla with the out code is that it is difficult for It to hadie

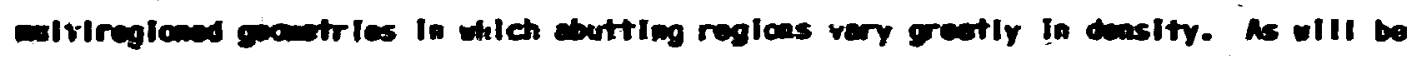
discused in Chepters 5 and 6. the first two exper inats perforiod in the ECF shielding

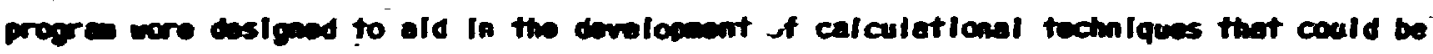
epplied in oor to onirraxe this prables.

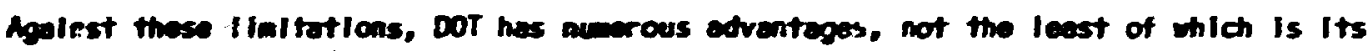

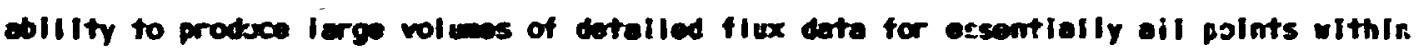
a syster in a relativily short tim ad of a reletively coconaical a it.

The ausu code (rof. 3) hes the sem linitations as oot plus it is restricted to

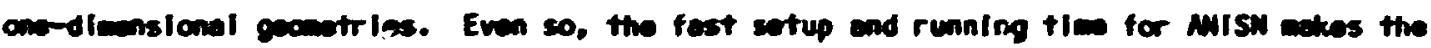

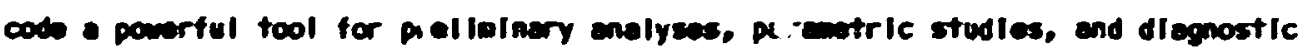
escescanonts.

\subsubsection{The varte corlo cods mase}

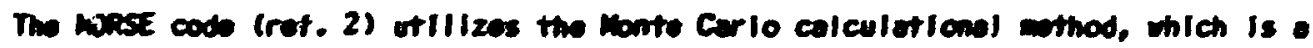
nemericel procedere besed on statistical theory and is the coly wathod by wich the

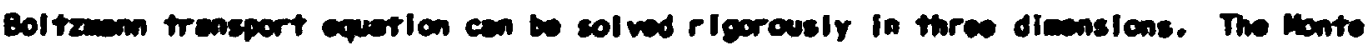
Cerlo wothod ean be thought of es following Individuel perticles as thry exacute mrendon

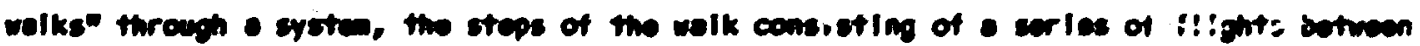
Intercetions. The positions of whlch the Imterections ceen and the rewits of the

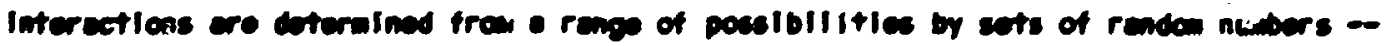
unice the aros nirto corio. 


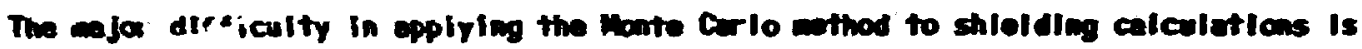
thet (1) a undely long ties is required to ganorete conough perticie histories to arrlwe of relleble fiex values, ad (2) calculations cen be practically parformed for aly a fen lacations w'thin a systum. As a result, mise calculations we not routinoly cerried

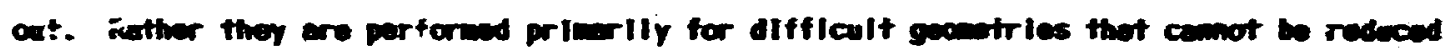
to two dimansions or to obtaln check polets for comperison with of calculations. On the

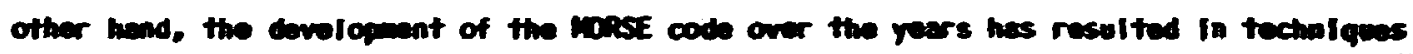

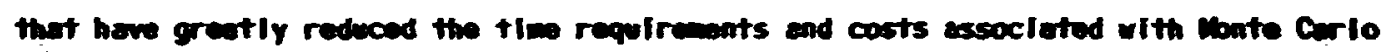
shlelding colculetions.

\subsection{MxILIaT oues}

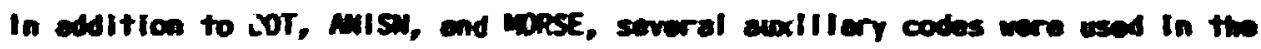
discrete crdinates analyses of the ECFR cxporiments. Ho attenpt will be wade here to

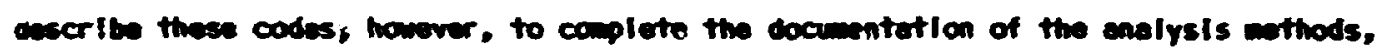
they are Iisted and referenced es follous:

SPAcETRM II (rof. 4) - Trensports DOT flubes emerglng from the slde and ond of a cylindrical configuration to detector wolnts byond the conflguration using: Dot-ill flux flle es input.

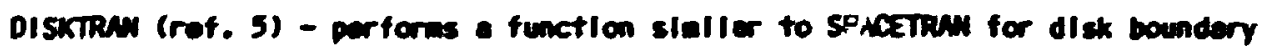
(cyllinder ends) sources using the oor top/bottan boundary flux arrays es Input.

FALSTF (rof. 6) - performs a Iast-ovent astinution fron discrote sourco polnts

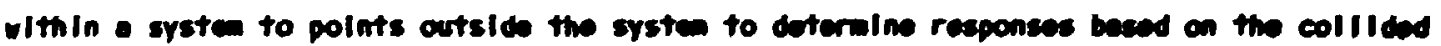
flux. Provision Is eade for estienting the contr ibution to the respense free a voundery source of the end of a crilader.

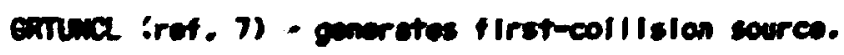

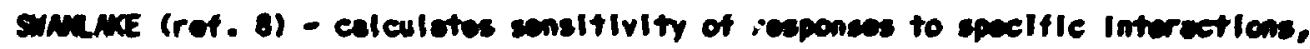
shleld composition, erousection data, etc.

VIP (rof. 9 ) - was ho-dimenslonal forwerd end edjolat flux menonts to produce

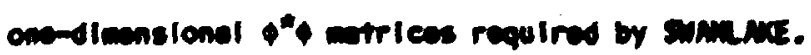


Forse (ref. 10) - a syste of codes to facllitute samitivity calculations.

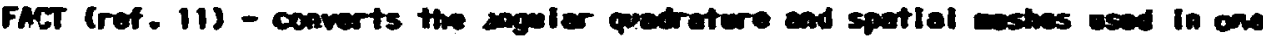
shisld region to the quadroture ad mesh required for the nact reglea. Also conprtes a defector respunsa of folding adjolat bodadery fluses eith the fonwer bondery source Incident an one of the cylladrical surfaces.

mpx (ref. 1E) - a systes of coles to facllitate cross-section processing.

DOSS (raf. 13) - a systen of codes to provlde graphical output of calcaleted eate.

\subsection{COPARIKS CHLCLATED UN IEASIRED RESUTS}

As has bean stated before, the calculational wethods and technlques dove: oped for the analysis of the shlelds of large reactor systems cannot be appl fed with confldance unless they have been conf inmed enperimantally, which neans, of course, thet the neesured results and the results calculeted in the analysis of the exper Inant cust be presented in the same terms.

DOT and moase calculations yleid "point" fluces (that is, fluces at specific polnts In a andifa). The moesurements are obtainoc as count rates, pulse helghts, ote. due to particle Interactions with the sensitive volume of the detector. In some cases callbretion factors, which wight Include the efficlency of the detection system, are applifed to the mesured data In order to obtein results in the sem unlts as quentitles normal iy calculated. In other cases, the calculated deto are converted to the seme units as the measured responses.

In the case of the Bonner bal is (sen Section 3.1.3), the calculated fluxes are converted to Bonner bell count rates using Bonner bell response functions (ref. 1 ,) thet ere folded with the calculated energy fluxes. Simlieriy. response functions ere evallable for the thermol uinescent detectors (TDS) (ref. 15) and the Hornyck button.

In the case of the spectranters (the ME-213 and hydrogen counter), the pulse-holght dete obtained with the specti muters ore "unfolded" vie the use of computer codes to obteln spectre that can be compered directly with the calculeted spectro. The calculeted 


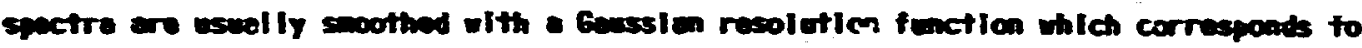
the entector resoletion in the spectronder spstem.

As will be woted in the fol louling chepters, the bulk of the xumerisoas are for

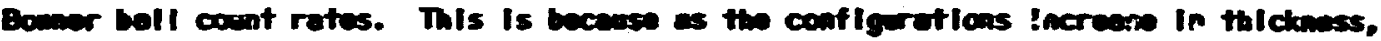

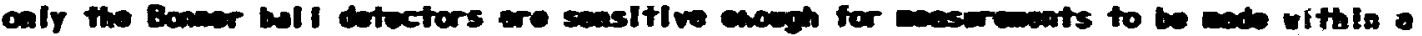
rewsonable length of tims.

\subsection{REFEVERTSS}

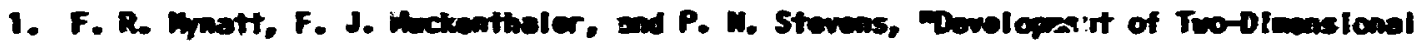
Discrete Ordinetes Transpart Tweory for Radietion Shlelding:" Computing Technology

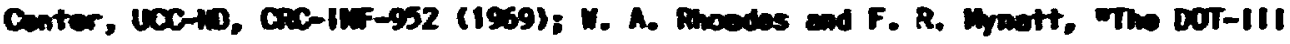

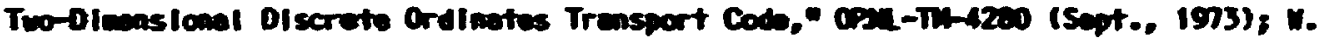

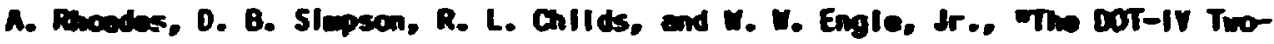
Dibansionsl DIscrete Ordinates Transport Code with Speco-begendent lash and

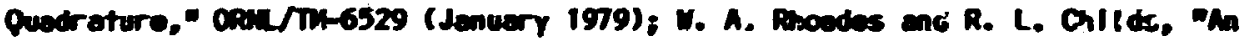
Updeted Version of the DOT-4 One and Two-0imanslonel Nustron/Phton Franeport Code, 00ic-585i (In revlew).

2. E. A. Streker, P. M. Stroveas, U. C. Irving, and V. R. Celn, Tho mase code - A

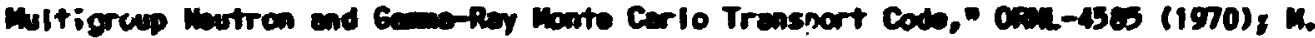

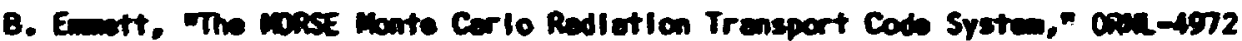
(Fobruen. 1975).

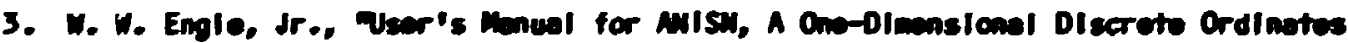
Trensport Cod with Anisotrople Senttering," Computing Technology Canter, Union

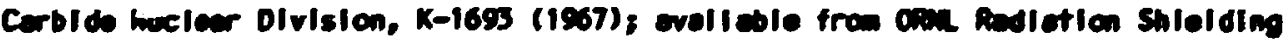
Informetion Center's computer code collection es Cod/254 (18in-360 version) or coc/2os love versiont.

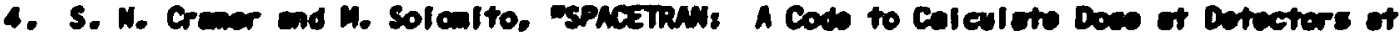

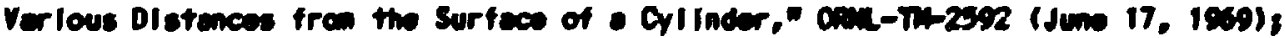

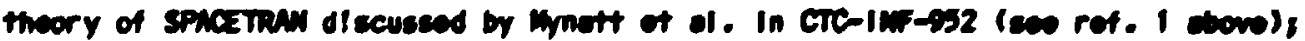
SPNCETRMI III Is en updeted version of the origlnal codp. 
5. DISKIRM was written by C. O. Slater; see C. O. Siater, S. M. Croer, and D. T. Ingarsoll. Mnalysis of the ORAu/TF GCrR Gris-PIate Shleld Design Confirmation Exper iment," Opul-5551 (August, 1979).

6. The FRSTF code, developed by R. L. ChIl ds of CRak, does a lest-event estimetion fro ciscrete source polnts in the system to external detectors to obtain responses based on the collided flux. The source is the total scattering source which cen be generated from the DOT fIux maments and the cross-section expansion.

7. ERTunch, developed by R. L. Childs, has not been documented separotely; hovever, It Is avellabie in the Dor code peckege obtainable fran the Ores Radietion Shielding Information Einter.

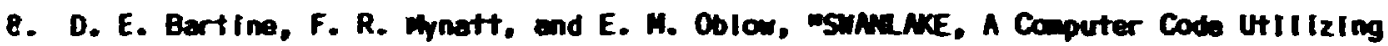
AISW Radiation Transport Calculations for Cross Section Sensitivity Anziysis," ORYL-TH-3809 (Moy, 1973 ).

9. R. L. Childs, D. E. Bortine, and W. W. Engle, Jr., Merturbation Theory and Sensitivity Analysis for Two-Dimensional Shlelding Calculations," Trans. Na. Mucl. Soc. 21. P. 543 (1975).

10. C. R. Malsbin, E. M. Oblow, F. R. Mynatt, and G. F. Flanagan, Whe Forss Sensitivity Analysis Code System," Trans. Mn. Mucl. Soc. 22, 792 (19:5); C. R. Melsbin et al., -Application of FORsS Sensitivity and Uncertalnty Mothodology to Fast Reactor Benchark Analysis," ORau/Th-5563 (Eniof-236) (Decamber, 1976).

11. The FACT code, doveloped by M. L. Gritzner, W. W. Engle, Jr.., M. A. Phoodes, D. R. Vondy, and L. R. Wlilians, is undocumenteds the current version is mainteinad by W. w. Engle, Jr., Oiml.

12. N. M. Greene, W. E. Ford, III, J. L. Luclus, J. E. mite, L. M. Putrle, end R. Q. wight, "Mwe: A Modular Code System for Generating Coupled nultigroup NeutronGam LIbrorles from EndF/B," Dau/Th-3706 (march, 1976).

13. D. T. Ingersoll and C. 0. Slater, wooss - A Collection of Graphics for Support of Diserete Ordinates Codes," vaulmp7ise (Merch, 1980). 
14. R. E. Merker et al.. Callbration of the Bonner Ball Neutron Detectors Used at the Towar Shielding racllity." opu/Th-3465 (Juce 30, 197I); C. E. Burgart and M. B. Emett, Monte Cerlo Culculations of the Response Functions of Bonner Ball Neutron Betectors, - oren/mi-5739 (April, 1972).

15. R. E. Worker, Wnalysis of TSF Experiments on Radiation Heating in a Stalnless Steal-Sodio CagR Radial Shield Mockup Using a 32-Inch Dianeter Coll Inated Bean Source," Opeu/The5992 (October, 1977). 
5. STUDIES OF MEUTRON STREAMIIS IN GCFR COAE MOCKUPS: SIKELE-CELL EXPRIIENT

\section{Experiment porformed by:}

F. J. Muckenthaler, R, M. Freastone, Jr., K. M. Heary, J. L. Hull

J. Lewin, J. J. Manning, J. M. Money

$$
\begin{aligned}
& \text { Analysis performed by: } \\
& \text { C. O. Slater, J. R. Knight }
\end{aligned}
$$

5.1. Introduction

5.2. The ExperImant

5.3. Preanalysis of the Experiment

5.3.1. Selection of Angular Quadrature Set

5.3.2. Definition of Source

5.3.3. Transport Calculations for Spectrum Modifler

5.3.4. Transport Calculations for Call Assembllos

5.4. Postanalysis of the Experiment; Comparison of Calculated and Masured Rasults

5.4.1. Defintition of Source

5.4.2. Transport Calculations for Spectru Moditler

5.4.3. Transport Calculations for Call Asseabll les

5.5. References 


\subsection{INTROOUCTIOA}

SInce the ORal Tover Shlelding Facllity experlnents for the GCFR progrea were to test the effectiveness of spec: $\{$ Ic shleld designs for the GCFR, It was fIrst necessary to ensure that pertinent experiments could be performed end, moreover, that they could be fully understood - that Is, to ensure that the experiments sould actually represent the design polnts in question and also that they could be analyzed.

It was Imadiately recognized that designing and analyzing shield experiments for the GCFR presented unIque problems beceuse of the design of the GCFR core Itself, the primary problem beling that the passagoways between fwel rods that al lowed the hel Iu coolant to fla down through the core (or up through the core) would also al ion neutrons to strean directiy fram the Innermost regions of the core. Thus any structure above or belon the core and its axlal blanket would be bombarded by Intense pockets of high-energy neutrons corresponding to the cool ant passegeways, and If any mockup experiments of shields to protect such structure were to be weanlngful, same technique for Including the streaming sources would have to be dev Ised.

Including the streaning sources In experiments would not alone suffice, hovever. It was also necessary to datermine the polnts of origin and energles of the energing neutrons and to IdentIfy their streaning paths, which meant that the experimental stresaing source would heve to be calculable. But at the time this progran was begun, no technique was ovallable for calculating the extreme and detalled experimental gecmetry that would be required, nor, of course, for calculating the gecmetry of the GCFR proper. Describing such a compl lcated system In Its actual three-dimensional gecmetry for calculations with the Monte Carlo method would have overwhelmad the computer and thus was not feaslble. The problem could heve been reduced to manageble proportions by hamogenizing the materlels of the core In a houdimenslonal cylindrical geometry for calculations with the discrete ordinates method but that would have ef Iminated the streaning peths es identiflable reglons. The question arose, then, as to whether the streaning pt thy in the core could be edequately represented with a heterogeneous twodimonsional model consisting of olternoting cyllndrical annull of high-density and lowdensity meterlals and whether the neutrons could be fol lowed through the low-density regions. 
As a first step in Imvestigating whether strecing could colculated with heterogeneous cylindrical models, several simple streaing calculations were performed wth the Dor discrete ordinates code for compereble hamogeneous and heterogeneous cylinders. The first heterogeneous model consisted of an Iron rod 17.239 an In dianoter by 762 m Jong) surrounded by an olf-streaing gap, the thickness of the gap (2.5654 m) sinulating the triangular pitch between fuel rods within a BCFR fuel element. Thus the configuration roughiy represented a single cell in a fusi element. The corresponding homgeneous wodel consisted of the same eterlals hamgenized over the entire region of the cylinder. The calculations for these two cylinders, plus calculations for other pairs of Fe-air and $\mathrm{LO}_{2}$-air cyilnwers, some in which the angular distribution ch the source ves varled, Indicated that streaning did indeed impect the results for the heterogeneous model. The calculations did not prove, hovever, that the streaming was accurate:y calculated with the moder. Such proof could be obtained only by agreenent of calculated streaing results and mosured streasing results for the same cylindrical configuration. As a result, the GCFR "shielding" progran at ORul began not with shlelding mockup experiments but rather with a single-cell core-streasing exper Imant and a corresponding analysis effort. The experiment, performed at the Tower Shlelding Facillty in mid-1975, Is described in detall in ref. 1 and sumarlzed below.

\subsection{THE EXPERIMENT}

The design of the single-cell experiment began with a modification of the Tower Shlelding Reactor II (TSR-II) radiation source to more nearly represent the neutron energy spectrim of the GCFR. Eariler calculations had indicated that flltering the TSRII bean through $102.64 \mathrm{~mm}$ of Iron and $25.4 \mathrm{~mm}$ of boral would give the desired spoctrum. Ther efore, spectrum modifier of this design placed 'n the bean adjacent to the reactor comprised the first component of the experimental crnflguretion.

Each mockup behind the spectrum nodifier corislsted of a 11.48-mm-dian "fuel pin" centered In a 15.748-min-dien by 1.374-milong ol uninun tube, the fuel pin surrounded by a 2.134-mine thick air annulus within the tube and the entlre call (tube) surrounded by vater (see FIg. 5.1). In sam cases the "fuel olf" conslsted of o $\mathrm{UO}_{2}$ rod and In others it conslsted of an Fe rod. The $\mathrm{UO}_{2}$ pIn, shown in Flg. 5.2, had an overall length of $1.3716 \mathrm{~m}$ 

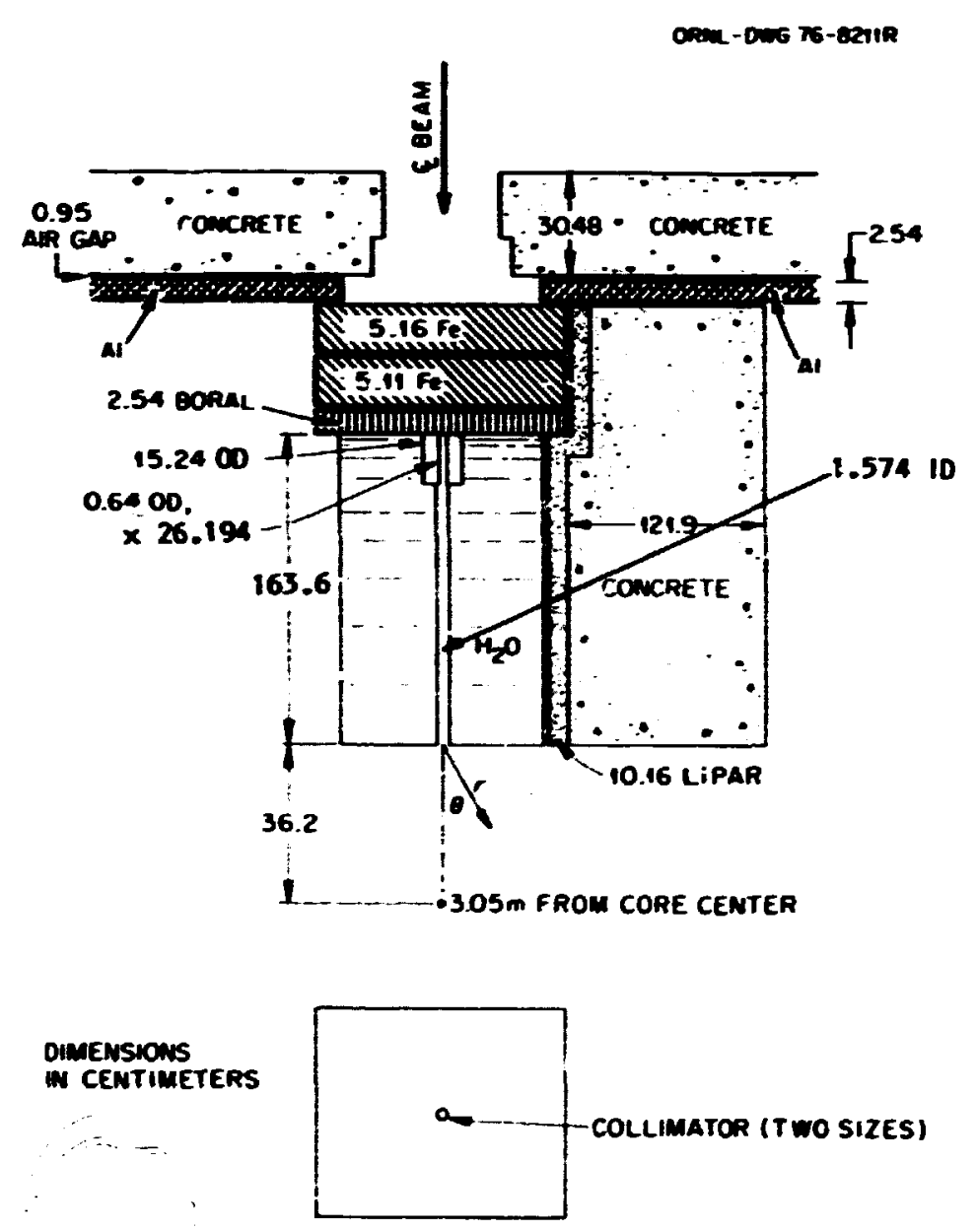

Fig. 5.1. Experimental Configuration for TSF Single-Cell Experiment.

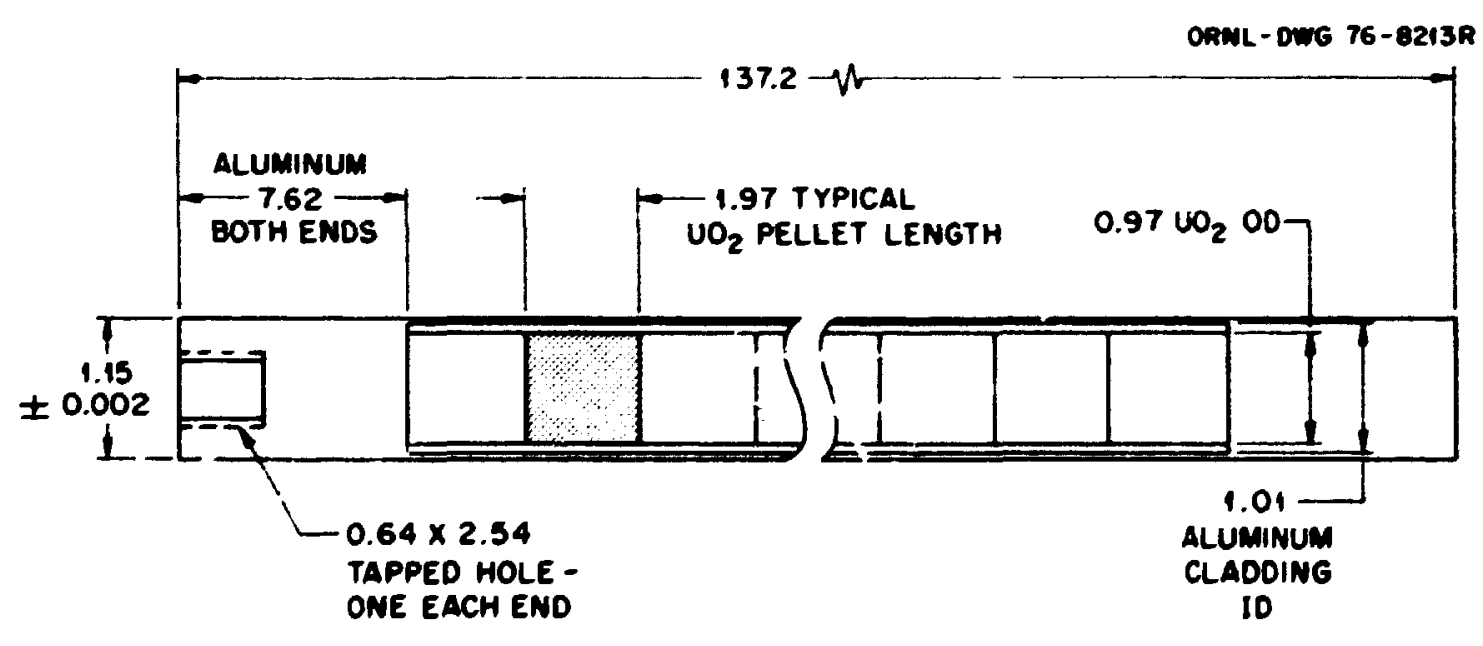

DIMENSIONS IN CENTIMETERS

Fig. 5.2. Scnematic of $\mathrm{NO}_{2}$ PIn. 
and contalined a 1.219 -10ng "active" section coprised of $1.35^{235}$ U-enrlched fuel pellets. The Iron pin also had an overall length of $1.3716 \mathrm{~m}$, but it had 76.2 ind long by $8.204-m-d i a n$ hole orll led in the source end.

Two different air-fillec source collimators were usad in the bea preceding the fuel pins: a 14.92-ce-dia collimator, which was larger than the diezeter of the cell; and a 4.928-ardia colliastor, wich vas saller then the dieneter of the fuel pin. Both collimators were $26.194 \mathrm{col}$ long. (DIameters specifled In Fig. 5.1 Inclute woll thicknesses - $0.16 \mathrm{co}$ for outer vall and $0.07 \mathrm{~cm}$ for Inner wall.)

Measurements of neutrons transaltted through the exper Imental configurations vere ade with Bonner ball detectors both behind the spectru nodifler and behind the Individual cell conf'gurations. In addition to the cell assemblles described above, measurements wert made for a configuration in wich the cell was filled with air oniy and for another in wirn the entire assembly was flooded with water.

With the various cell configurations it was antlclpated that several differences would be observed. Measurements for the volded-cell conflgurstion preceded by the large collimator would represent the upper bound of the experiment, whlle measurements for the water-flooded conflguration would represent the lower bound (l.e., the background). Also, a comparison of these measurements would isolate the neutrons transported through the cell from those transported through the water tank.

A comparison of the masuremints for the Fe pln configuration with the background case would indicate the ixtent to which the dir annulus enhanced neutron streasing through the cell, whlle a comparison of the measurements for the Fe pln configuration with those for the $\mathrm{VO}_{2}$ pin configuration vould indicete how the production of neutrons with in the pIn Itseif (fram ${ }^{235} U$ fissions) would increase the streaing. A comper ison of the large- and smsll-dianter collimator mesurements would Indlcate the reletive Impretance of moutrons entering the cell through the pin and those entering the cell through the ennulus. And finaliy, e conperison of the meesuramints on the cell axis with those made off the axis would Indlcate the relative magnitude of the "uncollided flux," thet is, the flux of noutrons troveliling through the olr ennulus directly to the detector without undergoling a change In direcilon through scattering. 
As It turned out, the measurements for conf Igurations in which the sall (4.928-amdia) collimator preceded the celis conic!ning fuel plns were essentially the swe as those for the water-filled cell (beckgrcund weasurement) and thus vere not meaningful. AIso, no significant differences were observed between the weasurements for the Iron pin and those for the $\mathrm{U}_{2}$ pin and therefore contribunions from fissions in the pin coula not be deternined. But before these results were known. a preanalysis of all the exper Imental conf Igurations had been undertaken both to ver Ify that the experiment had been properly designed and to further develop the analysis techalque.

\subsection{PREAMULSIS OF THE EXPERIMENT}

\subsubsection{Selection of Angular Quadrature Set}

Because the Iong and thin gecnetry of the experimental cel Is vould severely test the angular quadratures used in the DOT calculations, the first step in the preanalysis was to select an angular quadrature set. Two detal led quadrature sets vere avallable: a 147-direction negative-eta-biasod set and a 150-direction set which included all the directlors of the prevlous set plus an additlonal eta level contalning three more directions. In order to check whether elther of these rats wou,d be approprlate for the experimental analyses, they were both used for calculations of an additlonal "singlecel!" configuration. The case calculated was that of a totally aborbing rod surrounded by a vold, the rod having a volumetrlc shell source on 'ne end. Point detectors were loceted along the length of the rod $0.2 \mathrm{~cm}$ axay fram the surface, wlth al I locatlons having a "Ilne-of-slght" to portlons of the source. DOT results were obfalned with ihe two quad:ature sets and were compared with results obtalned with an analytic calculation and a Monte Corlo calculation that were nearly identical ano belleved to be correct. Both DOT calculetions tended to overpredict for locetions close to the source, giving approximately the same results. At distant locations both DOT calculations tendad to underpredict, with the 150-direction quadrature sat ylelding somewhat better results. It was concluded thet precise calculations could not be obtained with DOT for the extrane case represented by the hypothetlcal cell. The experlantal cell would not be nearly so extrem, however, and it was felt that the iso-direction set, which had 115 angles blased In the megetive ete direction vould be adequate for the experimental andysis. 


\subsubsection{Dafinltion of Source}

When the premalysis ves began It was knom thet the experlent would utlilze a new

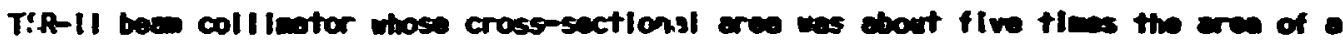

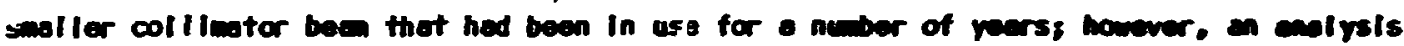
of the energy and angular distribution of the nen been was not alleble. For the

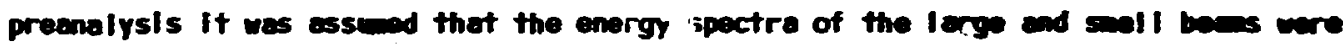
Identical (refs. 2 and 3) and that the Intensity of the lery been was 200 times thet of the sasll bean.

\subsubsection{Transport Calculatlons for Spactrua Modifler}

A so-group unlt source hoving the TSA-Il spectru was collepaed to a 10 -gromp structure and placed on the reactor side of the spactron adifler. A ano-dimanslonal PMISU transput calculation wes then pertorind to abtain the energent angaler flubes, neglecting scottering bock Into the spectren nodifler. The resulting anguler fluas were converted to ho-dimansional anguly fluwes in the Is0-direction quedrature set ant were then used as the boundary source for DOT calculat, ons of neutron transport through: the experleental conflgurations.

\subsubsection{Transport Calculations for Coll Assemblies}

The DOT calculations were perioned for all the experimental conflgurations described above (assining a vold for alr) and wre chected with monse Monto Cerio calculations in some cases. The cor calculations provlded mertron Icakeses from the experimental essamblics, and additional calculations vith the FALSTf code trasparted tho fluxes to points beyond in assembly.

The preanalysis rewilis were glven both a neutron flaxes in thres eaver groups

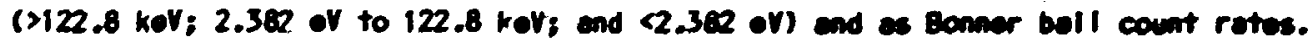

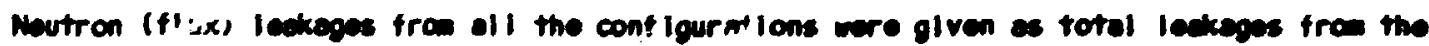

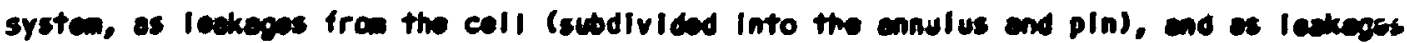
from the surrounding tank. Mutron fluces were olso calculated for verlous locotlons boyend the configurution speclified by the distence $r$ and angle thate $(\theta)$ shom in Fig. 5.9. The fluxes were converted to Bonner boll count rates for the locetlons benond the configurations only. 


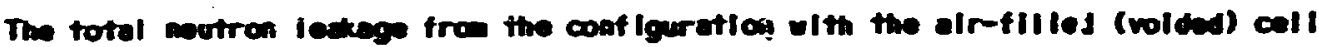

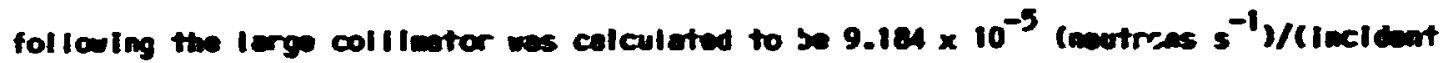
neutron $\mathrm{cm}^{-2} \mathrm{~s}^{-1}$, with the leakeg through the call comprisleg obout onemalf of the

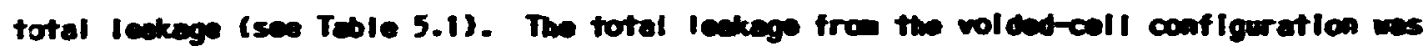
bigher of a factor of 13 then the iedage froe the weter-flooded configeration, the Increase being Iergily attributale to the strealng of the higher caurgr nutrons

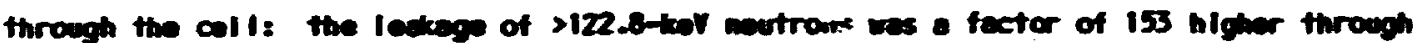

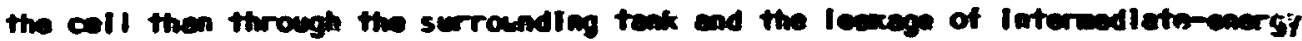
noutrons vas a factor of bout 17 hlgher.

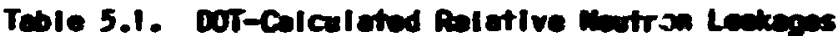
from Single-Call Nssmbl Ies (Preanal pals)

\begin{tabular}{|c|c|c|c|}
\hline & $\begin{array}{c}\text { Retio: } \\
\text { System Leckege }\end{array}$ & Rotio: Coll & Leakege/Teak Leakege \\
\hline Syste: & Beckgre nd & Totel & $3122.8 \mathrm{~km}$ \\
\hline Woter-filled (background) & $\mathbf{1}$ & & \\
\hline Vold. Iarge coll linator & 12.9 & 0.526 & 153 \\
\hline Yold, sall collleator & 3.1 & 0.481 & 8.99 \\
\hline iron pin, large collilimetor & 1.6 & 0.075 & 9.63 \\
\hline Iron pln, sall collientor & 1.2 & 0.021 & 4.74 \\
\hline $\mathrm{UO}_{2}$ pin, large coll linator & 3.4 & 0.036 & 8.14 \\
\hline$\omega_{2}$ pin, saall col ilartor & - & 0.147 & 1.83 \\
\hline
\end{tabular}

- Colculeted leakege belas beckground du to lack of comergence of thermel group.

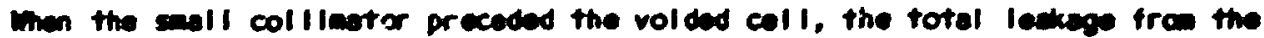
system was only a fextor of $3 \mathrm{hlgh}$, then that froe the weter-flooded syster, and the coll-to-tenk leckeng ratlo wes about 9 for the 3122.0 -kel noutrons and 2.4 for the Internedlate-onergy neutrons.

Imen the Iron pIn wos Introduced Into the confIguretion ulth the Ierge collifertor, the totel leakege fran the system wes higher by a factor of 1.6 then thet frem the

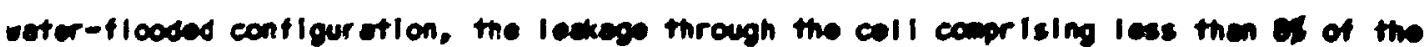


total leckege. In this cese Pre leckege of $>122.8$-tiol nestrons was a fector of 9.6 bigher fros the cell then froe the surroundiag tenk end the leakege of Intermediateenergy neutrons as a factor of 1.8 pigher from the coll.

when the sall collifutor preceded the cell wikh the iron pin, the fotal leakeges frow the systere and from the water teak were not greetly reduced from those for the Irompin Ierge-collibator systen, bet the loakge fron the cell was reducad by a factor of bout 3.6. Iargaly becasse of a reduction In the leaknge of 2122.8 -kel neutrons from the call (cell-to-tain ratlo = 4.7) and in splte of an Increase In the leakege of Iaterned ate-energr nutrons (cell-to-tank ratlo = 3 ).

Whac the $\mathrm{LO}_{2}$ pla wes substituted for the Iroa pin in the Iarge-coll inator conflgeration, the totel leakege irce the syste doubled, neariy all of the Increase

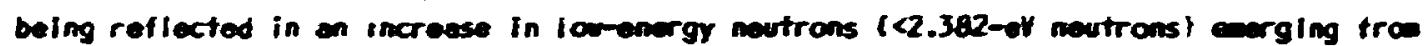
the tonk. The leakege fron the pin also wore than coubled, with Increases in al i energy groups. simever. the leakage fram the enrulus realned doinant in the overall cell leakege and was essentialiy the sas os that for the iron-pin case. The overall result was the: the cel!-to-tank leakege re+lo for the $\mathrm{UN}_{2}$ case was less then one-half that for the Iron cese.

Since the $\mathrm{LO}_{2}$ total cross section Is larger then the Iron total cross section, the increase in leakage ith the $\mathrm{LO}_{2}$ pin would apper to be attributeble to flssions in the $\mathrm{W}_{2}$ pin with the subsequent therealization of the fission meutrons in the tenk. The coservation that fissions are contributing significantiy is supported by the preanalysis results for the $\mathrm{WO}_{2}$ pin In the sal I-collibator conf Igur ation. Al though not datailed in Table I, the leakages from the tank and annulus in the sall-coll Inator $10_{2}-0$ In conflguration are greatly reduced from the leakeces for the I arge-collitator $\mathrm{WO}_{2}-\mathrm{D} / \mathrm{n}$ configuration. But the leakege from the pin Itself is significantiy increased, all of the Increase being in the <2.382-ol emeal croup. On the other hand, the total lackege celculated for the system is belou beckgrand owing to a leck of cenvergence of the low cherg group.

Monte Carlo (mase) calcul oflons of the leakege from the ennulus were performed for

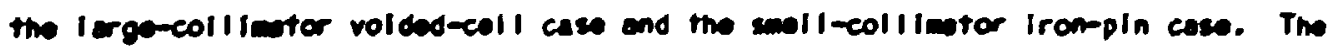


22.38-er meutron leakege calculated wth monse for the volded-cell case wes in feirly yood egrement it the corresponding DOT results: however. all other conperlsons showed the mopse tI wowes to be signiflcantly lower then the DOT fluxes. San of the dlscrepancy could possibly be doe to an Insufflcient nuber of events occurting wap within the tonk and In the vicinity of the cell In the morse calculations.

Dor calculations of the fluxes berond the cell Indiceted that the fotel fluces for the salli-collimator pin conf Igurations ware dbout equil to those for the water-flooded system (beckground weesurements), os, of course, was dIscowered to be the case when the nosurements wore ectially nats (see atove).

Finaliy, the DOT flueses for positions beyond the conflgarations were comerted to Bonner bal I count rates for subsequent comperisons with the masurenents and wth the postanalysis.

\subsection{POSTAMLYSIS of the EOERIIET: COMPRISON of CalcuLated AND VERSURED RESULTS}

Since the celis wth the sall collimator could not be properly neasured and slace the Iron pin and $\mathrm{LO}_{2}$ pln cases old not differ much in the presenalysis, the postenalysis was Ilalted to the large-collimator configuration including the volded cell and the Iargo-collimetor conflguration Including the Iron pin. The results fran thase celculetions ore compered with the corresponding experimental results in the following discussion.

\subsubsection{Definition of Source}

By the tien the postensiysts wes porfarmed, the energy spectrun and engular distribution of the noutron fiuxes In the Tsp-il Iargo bees hed been celculated end

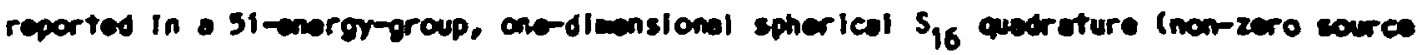
In elght positive directions) structure (ref. 3). Baceuse the enguler fluxes were def Ined with respect to the henispherical surfece of the TSA-II contalnant tenk, they had to be irensformed to a plem surfece for use as a boundery dick source in the DOT calculetions. This wa done by o tectinlque devised by merker, and the resulting pleme cource wis assund to be locerted in the pleme colneldent with the Insta surfece of the concrete collimeter. I.e., on the recetor side of the concrete shown In FIg. 5.3. 


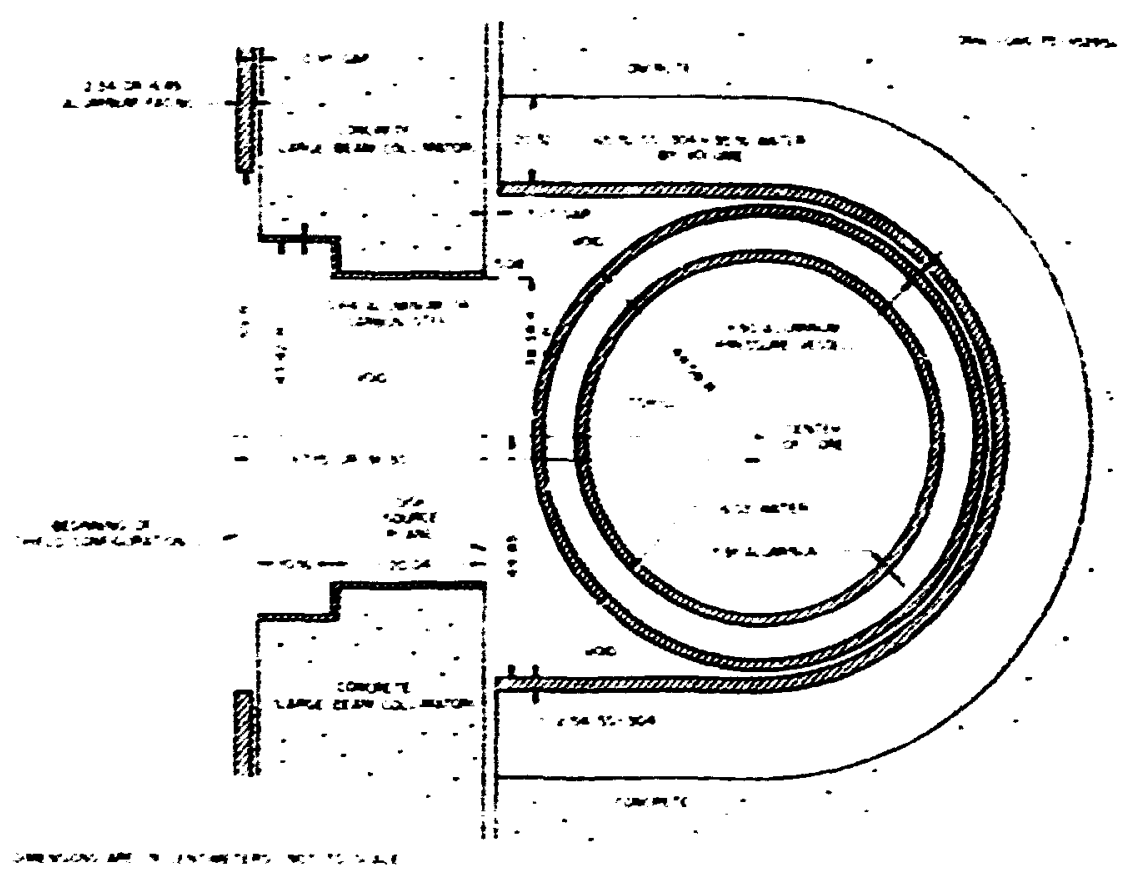

Fig. 5.3. Schematic of th. Tower Shielding Reactor (TSR-II) with Its Wide Beam Collimator.

\subsubsection{Transport Calculations for Spectron Modifler}

Calculations of the itrenspert of meutrons from the plane source through the spectrum nodifier were performed with the DOT code in two-dimensional guanetry using a 51-group GCFR cross-section IIbrary, the 150-direction quadrature set, and a $P_{3}$ cross-section expansion.

A vacuum boundary concition was specitiod for the outer foce of the spectrum moditier, and the angular. iuxes colculated to be emorging from that foce were soved on scalar flux tape to be used as the source for the succeeding part of the calculetion.

As an intermediate step, the angular tluxes calculotes to he emerging from the spectrun modifier were trensported vio the SPACE TRM 111 code to detector positions in the experimont. The fluxes at the detector position, were then folded with Bonner ball response functions to give Bonner ball count rates which could be compered with masured responses. The calculeted and messured count rotes were in good agreament, the colculated results being higher by less then 75 . This agreament indicetes not only the 
velidity of the calculationsl wethod but also the validity of the energy spectrun calculated in the enalyses for the meutrons exarging from the spectrum codifler. As shom In FIg. 5.4. the spectrien nodifler depletes the Iow-onorgy end of the TSA-II

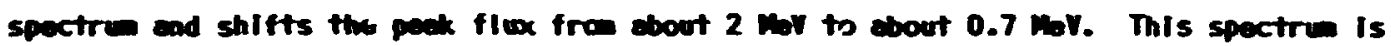
hardar then spectra calculated for three positions within the GCFR demonstration plant (ref. 4); therefore on a enlt source besis, calculations using this spoctron should result In greater meutron penetration then calculations uslang the other three spectra.

\subsubsection{Transport Calculations for Call Assemblles}

The calculation of the trasport of neutrons from the spectrum wodf ler through the exper Imental conflgurations ves cerrled out as in the preanelysls except that the 51grow neutron energy structure wes used rather then the 10-group structure. The results fra this part of the calculation were, es before, given as the neutron fluxes energling frow the experimental essembly.

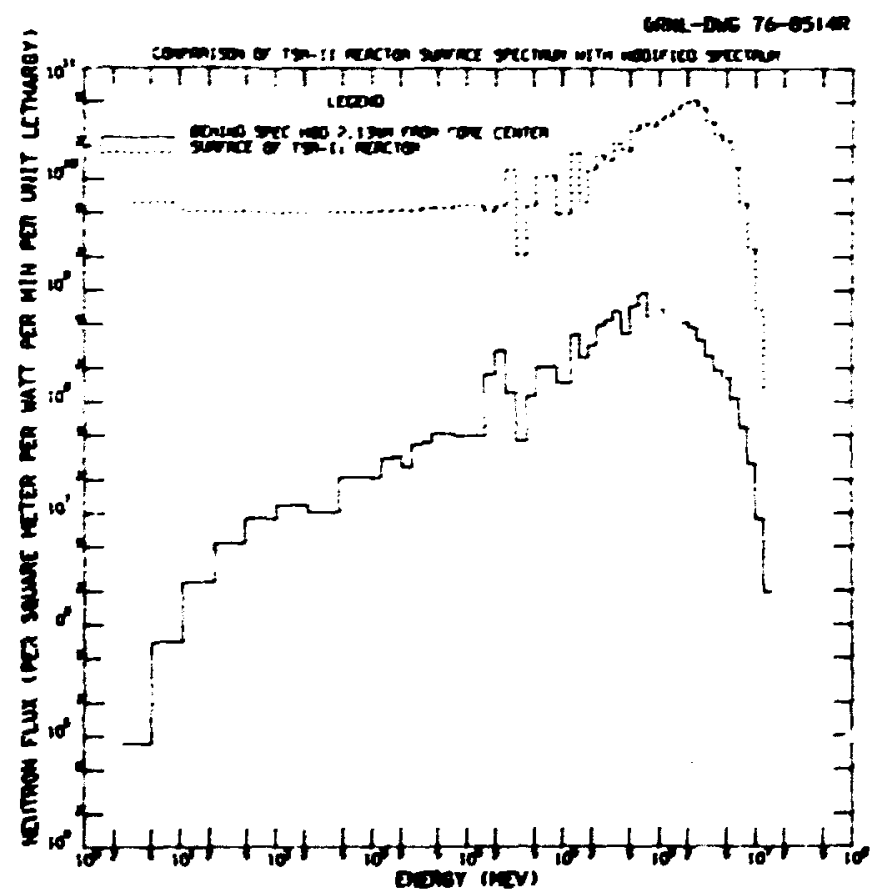

FIg. 5.4. Comparison of the Colculated Spectra of Noutrons Leaking fram Surface of the TSA-II Qeactor Yessel and from the Spectrim Modifier. 
Attempts to use a codifled SPMCEIRuk code for calculating the neutron fluxes at the detector positlons beyond the exporinental assenblles ware unstccessful; therefore, a code was written to calculate the uncollilded fluxes by doling a point source $1 / r^{2}$ kernal Integration fro the source of the spactru nodifier, aultiplying by an atte-'ntion factor. and integrating the product of the computed fluxes and the edjolnt angular currents over the Bonner ball hemlspheres, uslag a high-arder quadrature. The resulting uncollided fluxes were then added to the coll Ildad filwes.

The collided fluxes were calculated with FRLSTf for several distances behind the tank and at several radial positions at eech of these distences. For Eonner balls on the cell axis, the fluxes ware fol dod with the adjolint engular distribution and Integroted by the trapezoldal rule. (The assumed adjolnt flux had a cosine shepe; the angles were determined by the triengle formed by a point on the spectrun modifier centered on the cell. a polnt at the center of the Bonner ball, and a point on the surfece of the ball.) Interpolation was used so that the number of positions at which the responser, vere computed could be IIInlted.

Calculations of this type are very tI we consuming whan the detector is off the cell axis since the source azinuthal Integration must be performed in addition to the radial Integration. Consequentiy the analysis vas confined to on-axis detectors, except for a few $f$. Which no polint on the ball fell withln the radius or the hole (thet is, the center of ball was at $r>4.763 \mathrm{co}$ for the 3-1n. detector, at $r>8.573 \mathrm{~cm}$ for the 6-in. detector, and at $r>11.551 \mathrm{~cm}$ for the $10-1 \mathrm{n}$. detector).

Comparisons of on-axls masured and calculated Bonner ball count rates are shown in Table 5.2. For the volded-cell configuration, the calculated responses were 4 to 403 lower than the mesured responses. In the case of the Iron-pin configuretion the calculated responses were In som cases too low (by as much os 135) and In other ceses too high (by os auch as 618).

The calculated responses for the volded-cell cese epproeched the mesured responses only for on-exls locetions at lerge distances (s $300 \mathrm{em}$ ) beyond the exporimentel essembly and then only for the $3-1 \mathrm{n}$. end s-in. bolls. Since of these locetions the responses ore largely dw to uncollided fluxes, the near-egrcement would sen to Indicete (I) thet the source on the fece of the spoctria nodifler was falriy eccuretaly def ined and (2) thet 
Table 5.2. Comperison of Calculiated and Masured On-Axis Bonner Ball Count Rotes Berond Singlo-Call Assemblie: (Postanalysis)

\begin{tabular}{|c|c|c|c|c|c|c|}
\hline \multirow{3}{*}{$\begin{array}{l}\text { Distance Behind } \\
\text { Assebiy (ca) }\end{array}$} & \multicolumn{6}{|c|}{ Ratios Calculated/Masured } \\
\hline & \multicolumn{3}{|c|}{ Yol ded Cell } & \multicolumn{3}{|c|}{ Coll with Fe Pin } \\
\hline & $3-\ln$. & $6-\ln$ & 10-in. & 3-in. & 6-in. & 10-in. \\
\hline 12.7 & 0.706 & 0.792 & 0.609 & 1.041 & 1.368 & 1.182 \\
\hline 30.48 & 0.775 & 0.863 & 0.739 & 0.982 & 1.147 & 0.977 \\
\hline 152.4 & 0.856 & 0.833 & 0.703 & 0.875 & 1.013 & 0.875 \\
\hline 243.84 & 0.891 & 0.836 & $0.719=$ & 1.260 & 1.064 & 0.929 \\
\hline 304.8 & 0.963 & 0.897 & 0.700 & $1 . \$ 29$ & 1.112 & 1.005 \\
\hline 438.68 & 0.974 & 0.961 & 0.721 & 1.608 & 1.259 & 1.025 \\
\hline
\end{tabular}

Mosurement at $242.89 \mathrm{~cm}$.

the Il screpancles of closer distances vere due to difflculties in calculating the collided fluxces. At all locations behind the volded-celf configuration the calculations underpredicted the responses for the 10-in. ball, wich is most sensitive to high-energy neutrons. This way Indicate a fallure of a $P_{3}$ moments expansion of the flur. to give accurate forwardly peaked scattering sources for the high energy groups. On the other hand, the larger dianeter ball wey have needed a finor quaúature than the other balls to obtain e precise integral of the forward llux and adjolnt current over the ball surface.

In the case of the iron-pin configuration, the closest egreement between the calculeted and masured responses accurred on the exis of distances between 150 and 250 cin for the 3-in. and 6-in. balls and of distances betwesn 300 and $400 \mathrm{~cm}$ for the $10-\mathrm{in}$. ball. Fiuctuetions between sverpredictions and underpredictions probebly were due to overpredictions of the collided flux and underpredictions of the uncollided fiux. With the cell not open, the discrete surface integretion can lead elther to overprediction or underprediction when the contribution fram serticular source point to a point on the surfece of the detector is essigned too great o volght or toc emsil o welght. One prediction for en off-axis location of the 10-in. detector (at distance of $30.46 \mathrm{~cm}$ ) was actually 58 higher than the masured count rate. 
Som possible difficulties in the weasurements showid also be noted. Radial traverses with the $3 \mathrm{~m} / \mathrm{n}$. detector $30.48 \mathrm{~cm}$ behind both conflgurations and with the 6-in. detector 243.84 a behind the Irompin conf igoration ylelded measurenents that ware highly asymetric for polnts equidistent from the axis. And in som cases the 6-in. ball gave measurements thet differed by large factors at the sane locations. In the experimental count retes reported, oll thase messured risponses were given equal veight and averaged. Such a strong azinuthal variation in the clc in measuresents way Indicate that the experinental system was not really two-dinensional, or It woy Indlcate Impreclse locetions of the Bonner bolis in a sharply varying radiation fleld. Certainiy - defector mich nore nearly resebles a polint detector would hove been prefereble.

in conclusion, It would have to be ixditted that the gool of desigaing a single-cell exper inant that would represent a typlcal GCFR fwel-pin cell was not achleved. This was mainly because the small nlameter of the pin size required a source and collimator so sall that the system eppeored to be homogeneous. Also, the leck of an exper linental detector that could mosure polnt fl weces was a severe disadvantage for this experiment, since It was Inappropriate to assume that the fluxes energing from the sall-dlaneter cell would be unlform over the relatively large-dliweter Bonner balis. On the other hand, the colculations and woasurements were not in such radical disegreanent as to discredit the 150-direction quadrature set whlch ves to be used for the analysis of the later GCFR experiments.

\subsection{REFERENCES}

1. C O. Slater and J. R. Knight, "Analysis of the TSF GCFR Single-Call Noutron Streaing Exper Iment," Opal/Cor-80-16 (July 1980).

2. R. E. Marker and F. J. Muckenthaler. "The Absolute Moutron Spectrum EnergIng Through a I5-1/4-in. Colliator from the TSA-II Roactor of the Tower ShleIding Facllity," 0.0ul- nh-4010 (Decenoer 1972$)$.

3. R. E. Mearker and F. J. Muckenthalir, The Absolute Neutron Spectrun Energling Through the Lerge Baen Collimator from the TSA-II Reactor at the Tower Shlelding Facllity." OPWL-TM-5183 (Januery 1976 ).

4. Goneral Atomic Co. Project Staff, "300-min(e) Gas.Cooled Fast Brender Ractor Demonstration Plant," Goneral Atamlc Compeny Roport GR-A13045 (July 1974). 


\subsection{INTROOUCTION}

In order to further Investigate whethes a cepability could be developed for calculating neutron strealing in the hellum coolent passagewars between the GCrR fuel and blanket elements, a second experiment was designed in which an array of $\mathrm{UO}_{2}$ fuel rods was used. While the experimantal fuel pIn lattice was not typlcal of the proposed $300-\mathrm{mil}(\theta)$ GCFR core and blanket, fission neutrons would be produced throughout the array, mak Ing It sufflclently simller to the GCFR core thet measurenents of neutron streaning would give some Indication of streasing effects in the reactor.

The fuel-lattice exper Imant was performed In 1975 as a follow-on of the single-cell experiment. The experiment and its enalysis are described in refs. 1 - 3 and sumarized below.

\subsection{THE EXPERIMEMT}
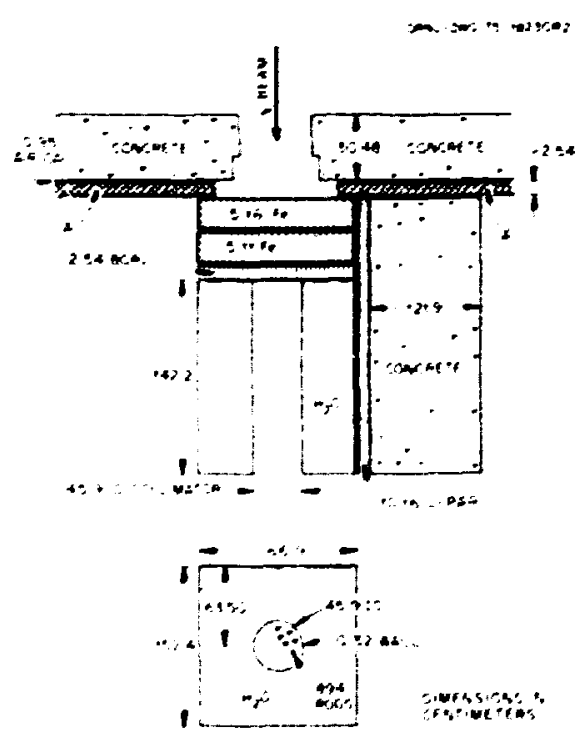

Fig. 6.1. Cont Iguration for the GCFR Fuel-Lattice NeutronStreaning Experiment.
The experimental arrangement for the fuellattice experiment was sibllar to that for the single-cell experiment except that the smal Idlaneter tube contalning the single-cell confIguration was replaced with a 0.459-10 by I. 42-m-long steel plpe contalning the fuellattice configuration. The fuel lattice consisted of 894 of the enriched $\mathrm{NO}_{2}$ pIns (see FIg. 5.2) arranged on a trlangular pitch of $1.425 \mathrm{~cm}$. The pIns were supported withIn the steel plpe by three 2.77-mo-thlck steel grid plates placed approximately of the center and about $7.6 \mathrm{~cm}$ from each and of the pipe. The full conflguration is shown In FIg. 6.1.

Since the configuration through the spectrum modifler was the same as in the single-cell experiment, the measuriments behind the spectrum modifler were not repeated 
(see Section 5.1). The masurements beyond the fuel Ioftice were wade uith the 3-, 6-, and 10-In.-dI D Bonner balls and also with two spectraneters: the TSF RE-213 spectroneiv, covering energles from approximately 1 to $15 \mathrm{maV}$; and the TSF hydrogen counter, covering energles from approximotely 0.02 to $1.5 \mathrm{kbl}$. All the detectors vere loceted on on arc whose radius ves 9.144 a from tha center of the exit face of the Iattice.

The unfolded spectra for E > $0.015 \mathrm{kll}$ based on the two spectroneter masurements are shown In FIg. 6.2. It should be noted that the date show s sharp drop over sall angular treverses fro the center iline. The totol flux at the 0-deg position is about 84 times that at the 7.5-dog position, whlle the total flux of the 2.5-deg location Is about a factor of 17 larger then that at $7.5 \mathrm{deg}$.

The Bonner ball mesurements ore discissed In Section 6.2 below.

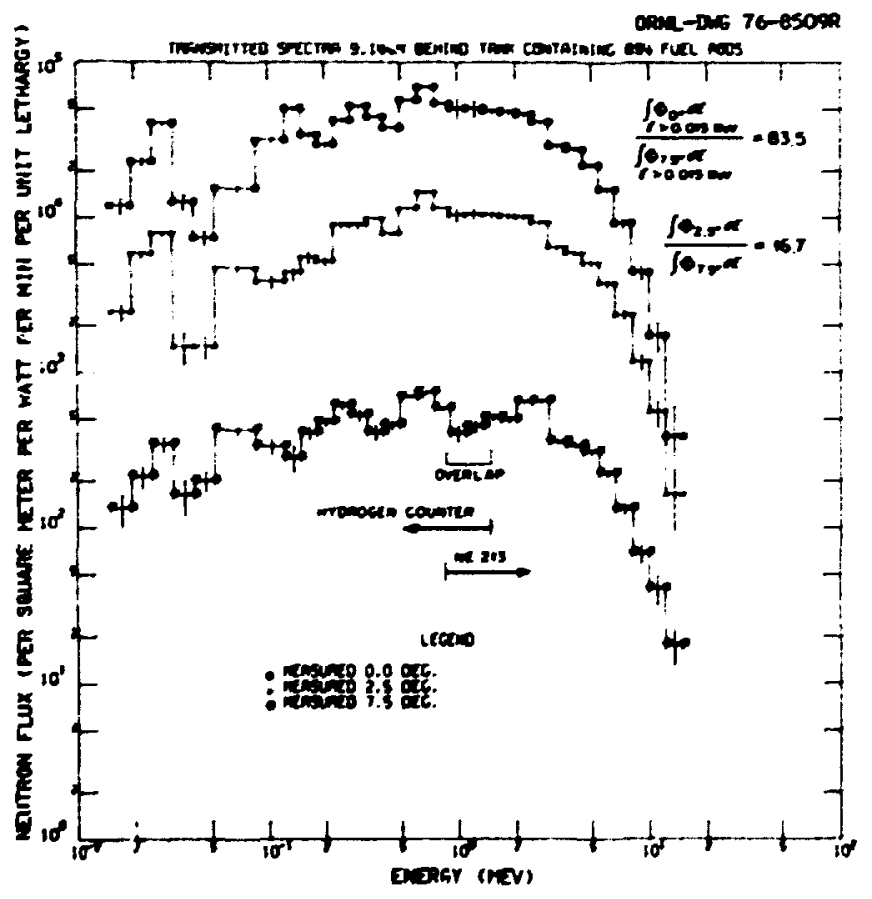

FIg. 6.2. Energy Spectre of Neutrons (E > 0.015 MVV) wasured Along an Arc $9.144 \mathrm{~m}$ Beyend Fual Latt!co. 


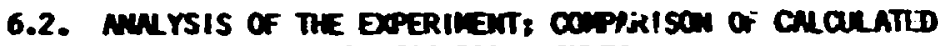
MD IEASTIED RESULTS

\subsubsection{DefinItion of Source}

The "source" for the anolysis of the fual-lattice experiment consisted of the angular fluxes colculated to be emerging from the spectrue nodifier in the earlier postanalysis of the single-cell experinent (see Section 5.3.2). The scal ar flux tape on whlch the fluxes ware savad provlded en Internal boundary source inonzero for negetive eto only).

\subsubsection{DOT Trensport Calculations for Fuel Lettice}

The fuel-lattice configuration was colculated first with the tro-dinansional discrete ordinates code DOT using two different wodels. In the fIrst model, the materlals of the core mockup [uranlum, oluinum, alr (vold), etc.] vere assumed to be blended together and distributed evenly vithIn the steel plpe; that Is, the model did not include neutron streasing paths per se. In the second model, anniler rings of vold were Interspersed between rings of homogenlzed fuel pin materioi representing the fuel pin orray, the rings being chosen to walntelin the nom-pin volume (44\$) in the experimental conflguration. The first heteroganeous model had $n$ Ine vold annull and elght fuel annull. In each cese, only four outer Iterations were allowed to converge the Induced fIssion source. As an Indication of the convergance after four outer Iterations, the DOT Iteration monltor showed a flinal source ratlo of 0.998 , or convergence to within $0.2 \%$.

For both the homogeneous model and the heterogeneous model, the calculated energent fluxes were transported to the detector positions via a modifled version of tne SPACETRAN III code. The fluxes were then folded with the detector response functlons to obtaln noutron count rates (for comperison with the Bonner ball masurements) and noutron energy spectra (for comper Ison with the ME-213 spectroneter and hydrogen counter masurements).

Comper Isons of the calculated and measured Bonner ball count rates are shown In Teble 6.1. It is apparent that with the homogonows model the calculation bediy underestimates the count retes ot 0 and $2.5 \mathrm{deg}$, but laproves at $5 \mathrm{deg}$. and is reasoneble of $7.5 \mathrm{deg}$. The calculation with the heterogeneous nodel overestingtes the count retes ot oll engles. 
Table 6.1. Comparison of Calcul ated and Meesured Bonner Bal I Count Rates on Arc 9.144 i Beyond Fuel Lattice

\begin{tabular}{|c|c|c|c|}
\hline \multirow[b]{2}{*}{ Detector } & \multirow{2}{*}{$\begin{array}{l}\text { Detector } \\
\text { Angle } \\
\text { (deg) }\end{array}$} & \multicolumn{2}{|c|}{ Ratio: Calcul otod/Masured } \\
\hline & & $\begin{array}{l}\text { Homugeneous } \\
\text { Model }\end{array}$ & $\begin{array}{l}\text { Heterogengous } \\
\text { Model }\end{array}$ \\
\hline 3-in. & $\begin{array}{c}0 \\
2.5 \\
5.0^{b} \\
7.5^{b}\end{array}$ & $\begin{array}{l}0.019 \\
0.079 \\
0.731 \\
0.896\end{array}$ & $\begin{array}{l}4.01 \\
1.39 \\
2.42 \\
1.77\end{array}$ \\
\hline 6-In. & $\begin{array}{c}0 \\
2.5 \\
5.0 \\
7.5\end{array}$ & $\begin{array}{l}0.012 \\
0.061 \\
0.687 \\
0.861\end{array}$ & $\begin{array}{l}4.37 \\
1.67 \\
2.63 \\
1.71\end{array}$ \\
\hline $10-\mathrm{in}$ & $\begin{array}{c}0 \\
2.5 \\
5 . C \\
7.5\end{array}$ & $\begin{array}{l}0.010 \\
0.052 \\
0.656 \\
0.602\end{array}$ & $\begin{array}{l}4.23 \\
1.52 \\
2.51 \\
1.50\end{array}$ \\
\hline
\end{tabular}

Model with nine vold annuli and aight fuel annuli.

background greater than $40 \%$ of total measurement.

Comparisons of the calculated and masured spectra reveal these sane t-ends. Figure 6.3 shows, for exaaple, that for the 0-deg position the homogeneous modei underestimates the neutron flux in all energy groups and, wreover, the calculated a.d measured spectra differ in shape. Conversely, the heterogeneou; model overestlmates the flux; however, the calculated and measured spectra are similar in shape, especially for energles above $0.1 \mathrm{MeV}$. At the 7.5-deg position, both models give better agreement with the masurements (see Flg. 6.4).

It was expacted that the results obtalned with a heterogeneous model mould move toward those obtalned with the hamgeneous model as the number of annular rings of fuel and vold were increased. This theory was tested with a second heterogeneous model conslsting of 24 vold ring, and 23 fuel rings, the rings belng chosen to more nearly represent the vold and fuel fractions of the experimental assembly as a function of radius. The result was that the total zalculated fiuxes decreased silghtly of the o- and 7.5-deg positions and Increased slightily at the 2.5-deg position. That Is, the calculated fluxes did move tarerd the homogeneous , luxes (and toward the masuraments) of the 0- and 7.5-deg locations, but thay moved away fram then of the 2.5-deg locetlon, probebly beceuse the thinner rings mer the center of the model were allowing more 


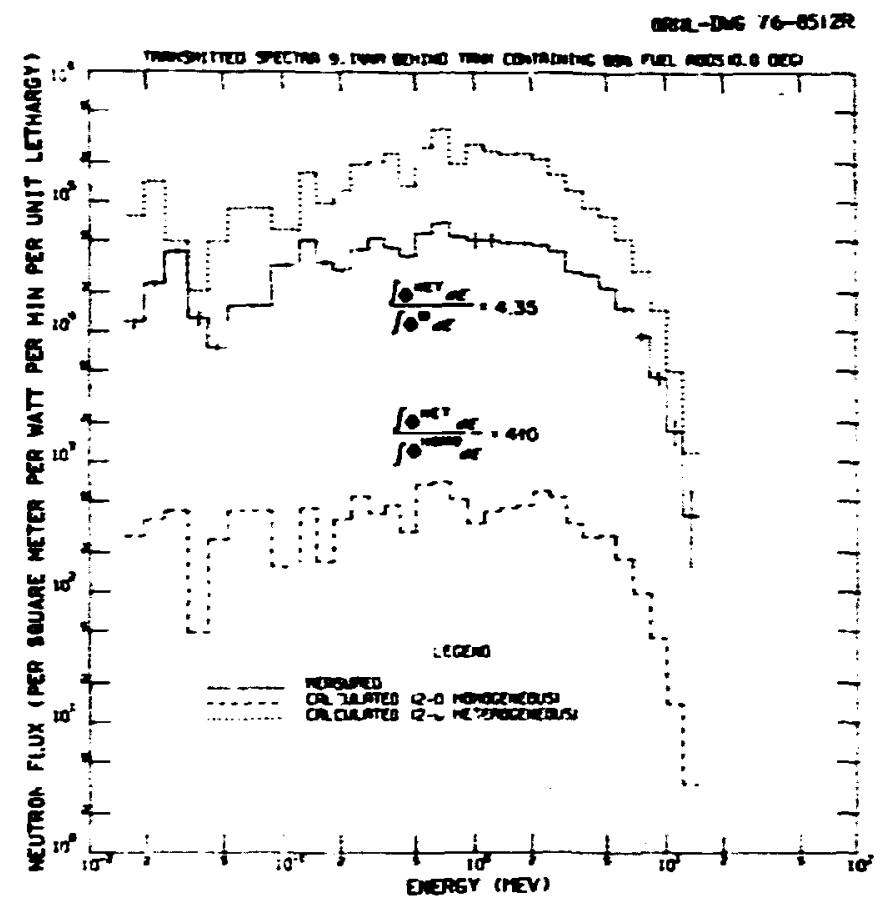

Fig. 6.3. Comparison of Measured (0-deg) Spectrun of Neutrons deyond Fuel Lattice Ii Th Spectra Calculated Using Meterogeneous and Homogeneous Models. Detector 9.144 m beyond conf iguration.

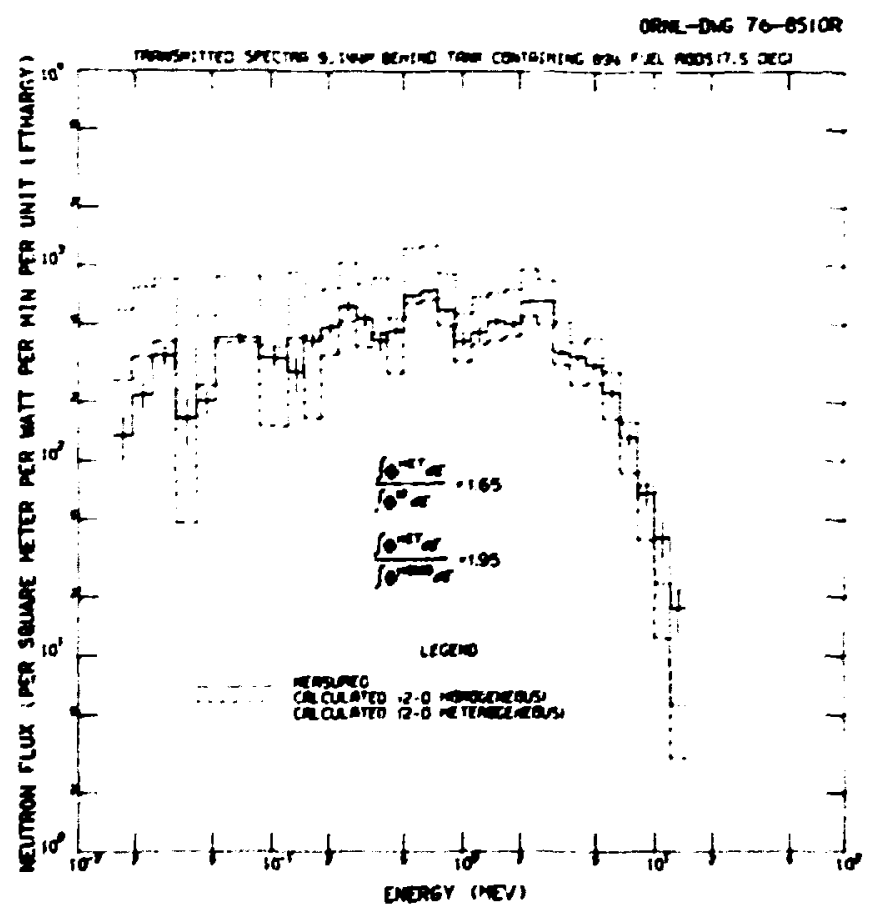

FIg. 6.4. Comparison of Masured (7.5-deg) Spectiun of Neutrons Boyor a fuel La:tice with Spectro Calculated Usling Homoganeou. und Haturogencous Modals. Detector on arc 9.144 m beyond conf Iguration. 
uncollided neutrons to raech the 2.3-din detector position. Interestingly, fhe noutron lestage from the fuel-lattic: assembly calculated with elther heterogeneous nodel was less then a fector of 2 higher then the leakage calculated ith the hanganeous wodel. but at a d!stance of $\mathbf{9 . 1 4 4}$ a the heterogeneous fl waes were factors of epproxinately $\mathbf{1 0 0 .}$ 30, and 2 higher at the 0-, 2.5-, and 7.5-deg positions, respectivaly. Thus a comarison of leakages alone wou! I not be the proper procedire for correction hameneous results for strealing effects at the two sal I engles, but It eight be appropr late for angles greater than $7.5 \mathrm{deg}$.

A comparison of the uncollided fraction of the totel flux calculated olth the two neterogeneous wodels showed that at the 0 and 2.5-deg positions the uncollilied flures dominated: therefore, it would seem that the masured fiuxes at these positions also would have been largely uncollided fluxes (uncollided after leoving the spectru modifier). However, at the 0-deg position the uncollided fluces obtalned with both wodels were higher than thi masured fluces by factors greater than 3 . To Investigate this further. uncollilded fiuxes were calculated with a third heterogereous nodel wich had 46 fuel rings and 47 vold rings. In this case, the uncollided fluxes at all three locations were lower than the measured fluxes and the flux at the 0-deg location was almost identical with the masurec fiux. Additiorai calculations showed that the shapes of the 0- and 2.5-deg spectri colculated with the first heterogeneous wodel agree with the shape of the spectru calculated for the neutrons leaking fro the spectrun mocifier, all of whlch tends to confirm that the fluxes at 0 - and 2.5-deg are largely uncollided fluxes. By cortrast, the spectra colculated with hoth the hamogeneous and the heterogeneous models at the 7.5-deg location ore simflor. The 7.5-deg spoctra ore al so comprised of lower energy neutrons, whlch Indlcates that the fluxes at 7.5 deg are largely cellided fl uses.

With SPACETRAN apparently giving. rellable results for DC : tions beyaid the configuration, one calculation was performed using the FALSTF code to calculate the collided fiuxes, stIII using SPACETRA for the uncollided fluxas since FALSTF did not seem to wort properly for the uncollided frection. The FALSTF colllobo fluxes were factors of 11.7, 2.2, and 1.4 times smaller than the SPACETRW collided fluxes at 0, 2.3, and $7.5 \mathrm{deg}$, respectively. The result was scmewh ot better agrecuent with the measured fluxes, the calculated to mosured ratlos beling ..17 of 2.5 anc 7.5 deg and 3.39 of 0 deg. 


\subsubsection{Monte Carlo Transport Calculations for Fuel Lattice}

With such large cliscrepencies between the DOT-calculated and mesured results, a Monte Carlo calculation was needed es a calcylatlonal benchark to separate nodalling errors from other errors. Although in princlple the Monte Corlo technique will allon the experimental configuration to be codel led exactly. the large number of fuel pins used in the expericental assemily precluced in. Lling in the nodel the one-haif of the essemily (180-deg segment) needed for an exact calculation of the responses at ell detector positions. Therefore, the calculations vere begun with 15 -deg segment, and to reduce the size of the calculotion, the tue' oins vere homenized (clading and $\mathrm{LO}_{2}$ were

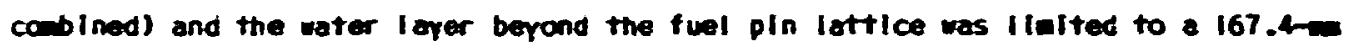
thlckness which sensitivity calculations (see belou) had indicated would be adequate. An albedo boundary wes placed at the 167.4-a depth, and albedo data generated ith the DOT code vere used in the calculation.

The resulting total $E>0.015$ meV flux calculated for the 0 -deg detectar position was higher than the masured flux by a factor of 1.68 , with 89.68 of the colculated flux being uncollided. The corresponding Dot-calculated fluxes had been higher than the masured fluxes by tectcrs of 4.35 and 4.11 (first and second heterogeneous mocels). Subsequentiy a Monte Carlo calculation was successfully performed for a 90-deg segment of the fuel lattice and it yielded similor results: lotal fluxes that verc 1.83 times higher then the masures fluxes, with 91.23 of the calculated fluxes being uncollided. In this case a heterogeneous model was usad, but the fuel-pin cladding and $\mathrm{NO}_{2}$ were not made distinct zones; that is, they were homogenized to form a single sin zone.

On the basis of these comparisons, it can de states that the DOT calculations with heterogeneous modeis are very conservative, overestimating the detector responses by several tectors. Of course, the Monte Carlo calculations also overestimate the flux, but much less so than the discrete ordilates calculations. The Monte Corlo discrepancy is largely attributed to the basic dato ised to describe the experlanet since the Worite Co. iO statistics for the totai flux are reasonably good (103 standard deviation). 


\subsubsection{Sonsitivity Analysis}

As puinted out above, the Monte Cerlo calculations were guldad someuhat by a discrete ordinates ser sitivity andysis, wich wes perfored with the hodiensional homogeneous nodel. In fact, the wain purpose for porforaing a sensitivity analysis was to identify the ileprtance reglons" (both geontric regions and energy regions) for the lonte Carlo calculation, and, in perticular, to deternine the winime thickness of water that hac to be included in the calculational nodel.

The general procedure in a sensitivity andiysis is to I Ink the uswol "forward" discrete ordinotes calculation (that is, the homogeneous calculation discussed earlier) with an "adjolint" (backward) calculation in which the source is the datector response function. The caiculated results then shou to which gacaetric reglons or to which particie interactions the detector response is most sensitive.

In the sensitivity analysis performed for the fuel lattlce contiguration two adjoint calculations were performad, one using as its source the response function of the 6-in. Bonner ball at a location 1.524 a behind the confls ration and the other using the response function at a locetion $3.048 \mathrm{~m}$ behind the configuration. The two detector positions vere required in order to datermine the varlation of the sensitivity with detector pesition. The code GRTunch was used to generate a first-collision source for the adjolnt calculations so that a point response rother than a vol une-averaged response covild be obtalned, and the VIP code was used to prepare tron the two-dimensional forward and adoint flux ments the one-dimensional form required by the Swallak sensitivity code.

In addition to guiding the Monte Corlo calculations, the sensitivity analysis revealed the cross sections and moterlal compositions to which the $6-i n$. Bonner ball responses were most sensitlve. Thls, in turn, provlded a prlority Ilst of areas where uncertainties should be reduced for subsequent GCFR calculations.

\section{4. conausions}

The fuel-lattice experiment demonstrated conclusively that neutron streaing could be effected In an experimant. Analyses of the experimont wth the discrete ordinates code DOT showed that a hamogancous cyllndrlcal nodel underestinatod the strealing effect 
and a hetarogeneous model consisting of concentric annull of fuel and rold overestiacted the effect. Thus DOT calculations cen be used to brecket the streaing that could be expected in a GorR-type core.

The analysis also shored that the discrete ordinates calculations gave energy spectra that generelly agreed in shape with the exper Imental spectre. For angles less then $5 \mathrm{deg}$ from the axis of the configuration, the spectro were very siallar to the energy spectren of neutrons inedietely behind the spectru nodifier, which indicated that the detector response wes largely due to neutrons transeitted through the fuel iattice without undergoing scatterings (that is, to the uncollided fraction).

The overall conciusion was that neutron streasing in a GCFR core mockup or in the GCFR proper could be epproxinately calculated with a rabination of discrete ordinates and Monte Carlo calculations. Discrete ordinates calculations with a heterogeneous model would establish the upper linits of the strealing and deteraine the energy spectro. The results could then be normalized to a Mante Carlo calculation to nore nearly predict the agnitude of the streaning with assurances that the predictions would be conservative.

\subsection{REFEREMCES}

1. C. O. Siater and D. E. Bartine, Mrelim : nary Anaiysis of a TSF Experiment on Neutron Streding Through a Lattice of GCFR-Type Fuel PIns," GCR-76/37 (November 1976 ).

2. C. O. Slater and M. B. Enett, WFinal Analysis of a TSF Experiment on Neutron Streaing Through a Lattice of GCFR-Type Fuel PIns," ORaL-CCR-78/5 (Februery 1978).

3. C. O. Slater and M. B. Enmett, MAnalysis of a Fubl-Pin Meutron-Streaning Exper imant to Test anthods for Calculating Neutron Danege to the GCFR GrId Plate," in Proce. Eltth int Coote_Ratoc Shiniding, 00. 873-660, Sclence Press, Princeton, N, J., 1977. 


$$
7-1
$$

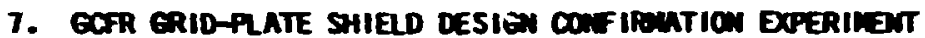

Experlmont perfornad by:

\author{
F. J. Muckenthaler, J. L. Hall. L. S. Hanlag \\ Anelyels portoniod by: \\ C. 0. Slater. 5. M. Oreor. D. T. Ingarsol I
}

\title{
7.1. Introduction
}

7.2. The Exporiment

7.3. Design and Preanalysis of the Experimant

7.4. Analysis of the Experiment: Comparison of Calculated and Masured Results

7.4.1. Definition of Source

7.4.2. Transport Calculatlons for Enpty Cavity Conf Iguration

7.4.3. Transport Calculations for Fuat-PIn ConfIgurations

7.4.4. Transport Calculations for GrId-Plate Shleld Conf Igur ations

7.4.5. Transport Calculations for Prototyplc Grid-Plate Configuration

1.5. Sumary

7.5.1. Fual-pin Conflgur ations

7.5.2. Grid-Plate Shield Conflgurations

7.5.3. Grid-plate Configuration

7.6. Conclustons

7.7. References 


\subsection{InTrEOUCTION}

As has been ephasized In Chepters 5 and 6, froe the earl Jest GCFR designs It was apparent to shleid designers that axial neutron streaning through the hel iu passageways within the reactor core could result in intense fluxes of high-energy neutrons Inpinging on structure above and below the core. Of particular concern was possible neutron damage to the grid plate, a 61-ca-thick stainless steel plate which res to hold the fuel and blanket elements firmly in position. At the time these studies were being performed, the GCrR design specifled that the grid plate vould be top-wounted and would conteln 16.2-cmdia holes that would mate with the cylindrical upper sections of the fuel elements. Protective shielding was to be provided in the upper sectlons of the fuel elements (see Fig. 2.3 In Chapter 2) but just hor effective the shielding would be in preventing danege to grid plate could not be accurately predictod. On the bdsis of the studies descilibed in the two precedilig chapters it was known that the streaning effect could be bracketed with avallable anairticai techniques, but wore precise Information was needed since the grid plate would be required to last the Ilfetine of the reactor and overdesign of its shlelding would entall a high sconomic penalty. Thus experiear'al quantification of the neutron straming in a prototyplc gecmetry seanec essential, and the decision was made to perfori shat was to be labeled the MCFR grid-plate shield design confirmation exper Iment."

To ensure that an experiment could be performed that would provide the needed answers, exhaustive calculations carried ut both to gulde the experinental design and to predict the masurement; thet would be obtalned with the as-designed con: Iguration. These calculations were described In an ORML GCFR progress raport (ref. 1) and are sumarlzed below In Section 7.3, whlch is preceded by a brlef descriptlon of the experiant as It was fInally performed at the OPall Tower Shlelding Faclilty In 1978 (see Section 7.2). The experiment Is presented in more detall In refs. 1, 2 and 3, and Its final una'vsis, sumarlzed here in Section 7.4, is described in refs. 3 - 5.

\subsection{THE EXPERIMENT}

Dasign calculations for the grld-plate shield confirmation experlment (exe Section 7.3) were begun In Jenuary, 1977, fol lowing a meoting with Gonaral Atomic at which ORWL presented a prel iminary conceptual design for the experlement and preliminary estimates of 
the sdequacy of the design. Prinary concern wes thet the scurce conerinly from the fuel pins and that the seven subessemblies would edequotely represent lerge erroy effects. Detalled dasign features wore developed doring preanalysis and dering several meetings with General Atoric Company.

The full configuration as finally designed Is show In FIg. 1.1. The first section, the sinulation of the GCFK core and axial blantet, consisted of slightly earlched $\mathrm{NO}_{2}$ fuel pins (1.99) ${ }^{25}(U)$ arranged In seven subassembl les that resembled GorR subassablites.

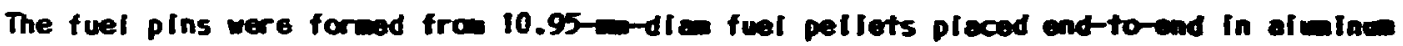
tubing having 0.815 -thick valis. The fueled section of eech pin ves 121.92 an long and contalned $: 035.49 \mathrm{~g}$ of uranion. Alol us studs on cech end of the fuel pins extended their overall length to $127 \mathrm{co}$.

one-Dwe re-15isme

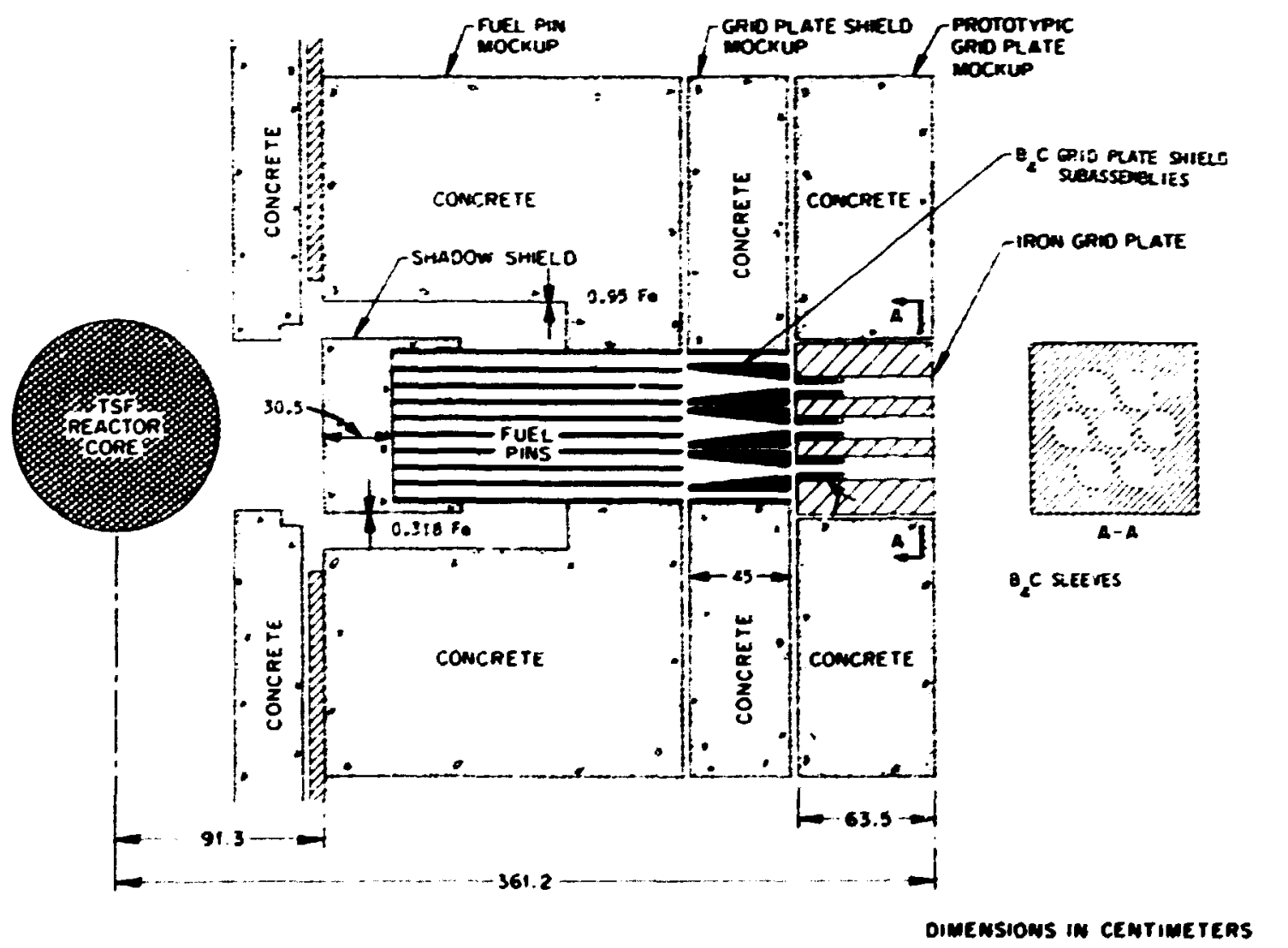

Fig. 7.1. Experiantal Confliguration for TSF-GCFR Grid-PIate Shield Conf Irmation Experimint. (Note: "Bottcan" of core is adjecant to shadow shleld.) 
The casing for each of the seven fuel subassumblles vas hexagonal In cross section and wes constructed from 0.30 -cm-thick carbon steel. Two types of subassenblles vere fabrlated: one set In which each subessembly coniolned 127 pins on a pltch of $1.58 \mathrm{~cm}$ and anotter in wich each subassebly contalined 91 pins on a pltch of 1.80 ca. Support grids that were $0.318 \mathrm{~cm}$ thick were placed at each end of the assembly and at the aldsection to eainteln the proper pitch of the fuel pins. The distance between the facing surfaces (across flats) of the subassemblles was $18.3 \mathrm{~cm}$, and, Ilke the fuel pins, the subassemblles were $127 \mathrm{~cm}$ long.

Detalls of the fuel pins and subassamblies are shown in Figs. 7.2 - 7.5. The small steel pieces visibie in Fig. 7.4 near the onds and alddie of the outer flat surfaces of the subassembl les were used to vary the specing between subessemblles for sane of the meesurements. In the experiment the cluster of seven subassembl les (a contral subassently surrounded by six subassembli les) was surrounded by a 0.95-ca-thick I8-sided iron cylinder (see Fig. 7.5). The cyllinder size vas flxed; thus, os the spacing between fuel subessembllies decreased, the vold thickness between the outer surface of the fuel cluster and the surrounding cyllinder increased.

Precediny the core-blanket section in the experinental conflguration was a 76.2-cmdien by 30.5-cm-thick concrete "shadow shield." As noted in FIg. 7.1, inis shield surrounded the "bottan" section of the fuel and was Itself surrounded by a vold that extended "upwar d" beyond the shleld to surround a large frection of the fuel sectlon. With this arrangement the section slaulating the GCFR core and blanket was protected from direct radiation from the TSR-II and the primary radiation source for the experiment became the neutrons produced by fissions In the fuel pins, the fissions being Induced by TSR-II noutrons that scattered around the shadow shleld Into the fuel section. Both the shadow shield and the concrete surrounding the vold vere Il nad wth Iron. The outer surface of the shadow shield and the face of the shadow shleld adjecent to the fuel pins were covered wth $0.318 \mathrm{~cm}$ of Iron, while the surrounding concrete was IIned with $0.95 \mathrm{~cm}$ of Iron.

The second section of the experimental configuration, the grid-plate shield simulation, consisted of seven 45-ca-long subassamblles that were al so hexagonal in cross section to match the "upper" ends of the soven experimental suel subassemblles. (In the GCFR the shield is integral with the fuel ascambily and is situated between the end of the 


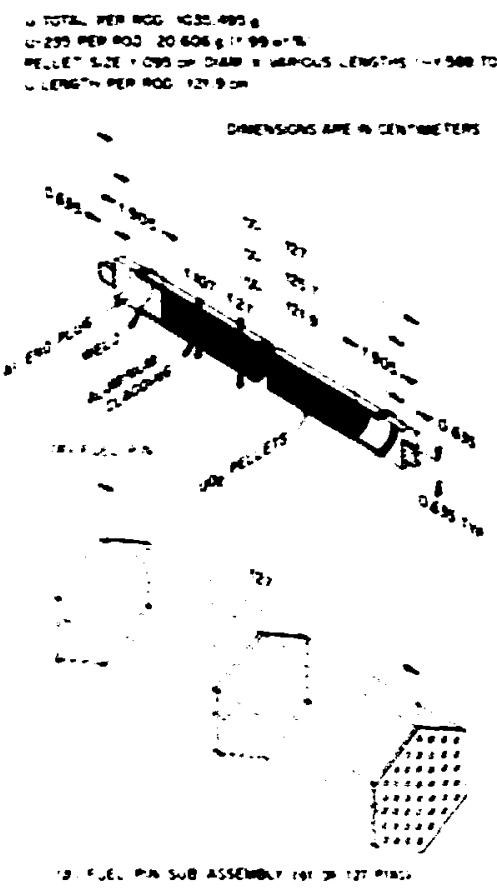

Fig. 7.2. Schematics of (a) Fuel Pin and (b) Fuel-Pin Subassembly.

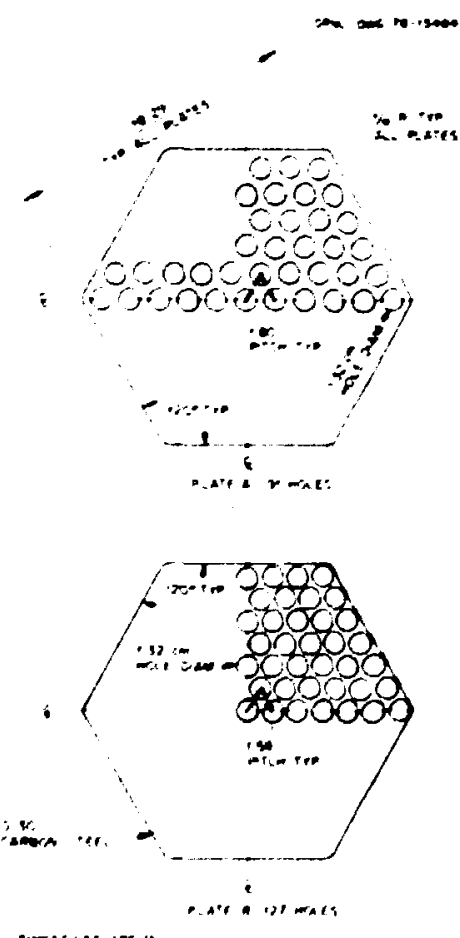

FIg. 7.3. Fuel-pIn Support Grids at Center and at Eoch End of Experimental Fuel Subassemblies. 


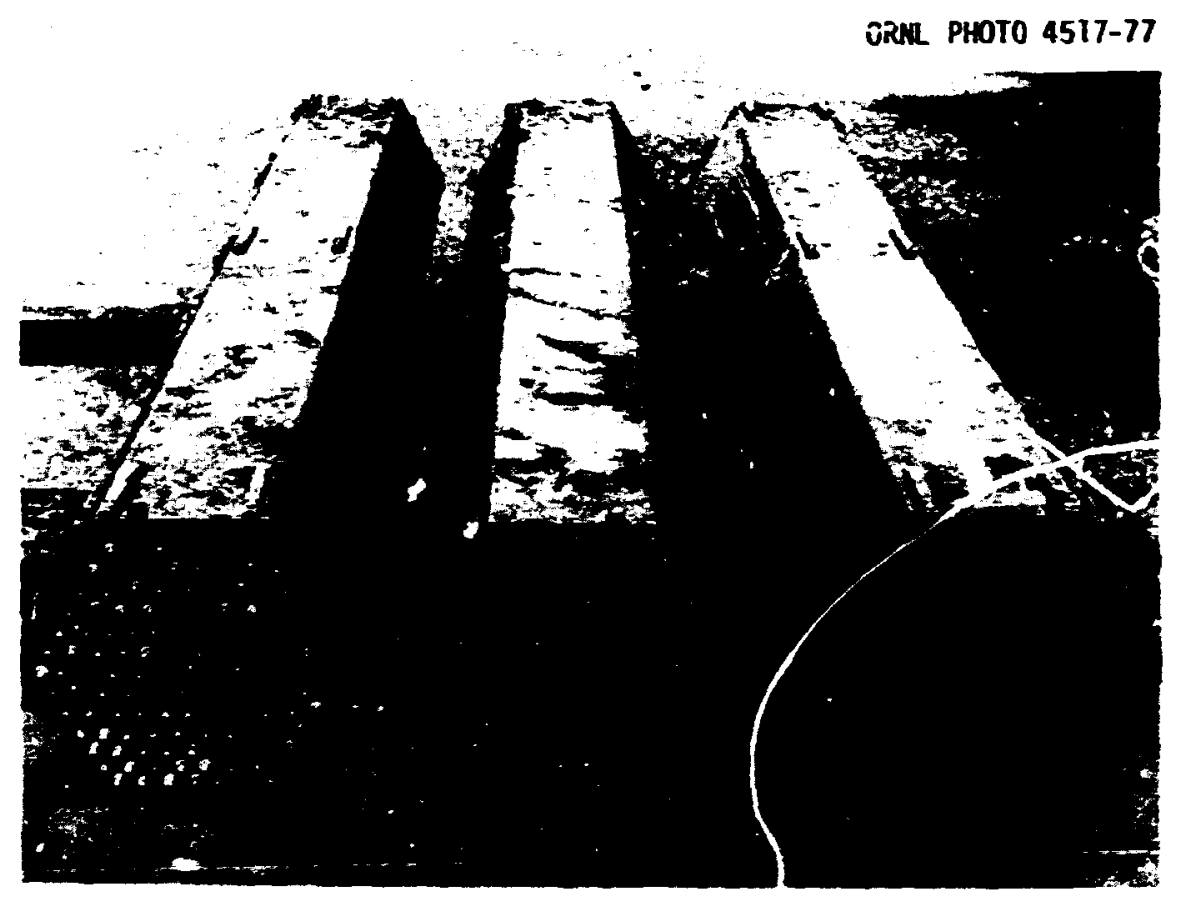

Fig. 7.4. Experimental Fuel Pin Subassemblis:: Enpty Subassembly (RIght); full Subassembly (Left); and Complete Subassembly with End PIates (Center).

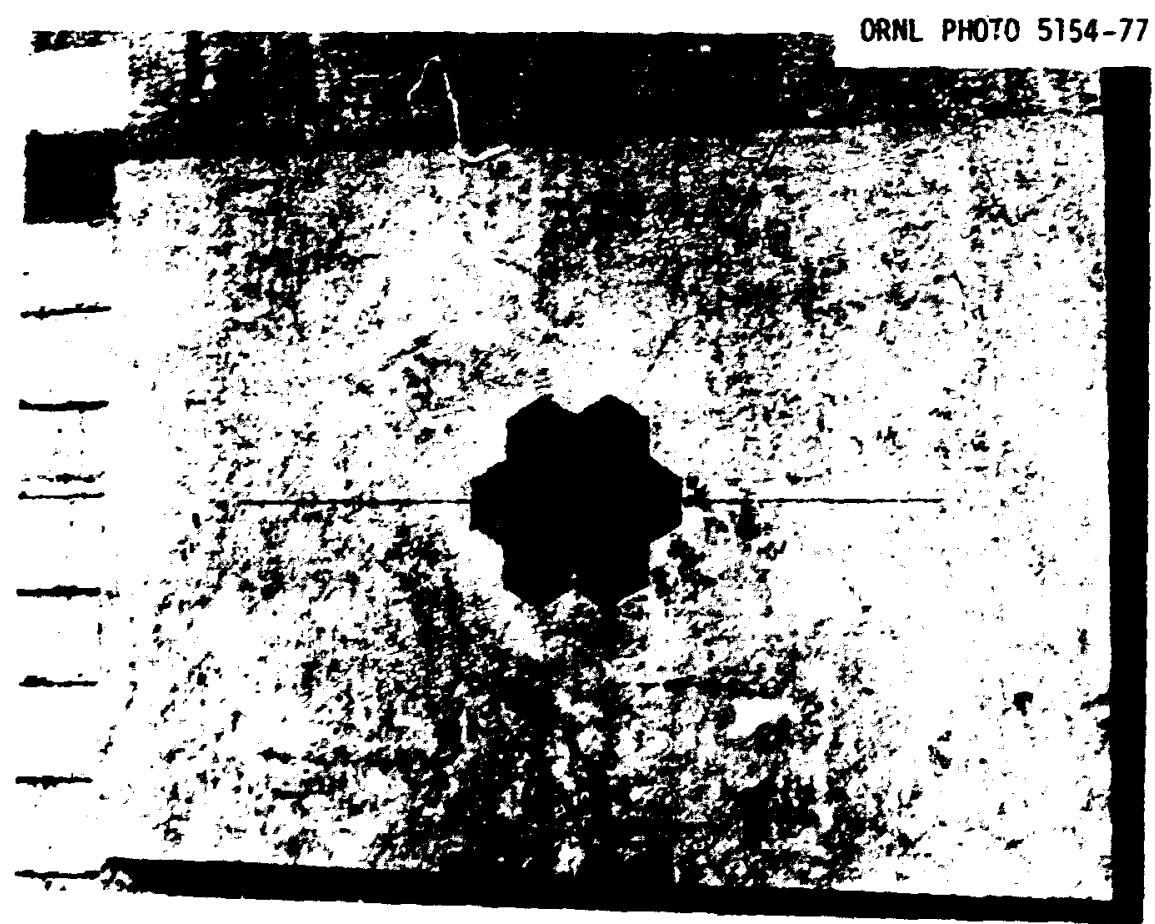

Fig. 7.5. Experimental Mockup of Seven Fuel Pin Subassemblles (Surrounded by IronLined Concrete). 
fuel pins and the grid plate.) A concrete envelope surrounding the shleld subassembl les had an 18-sIded Inner Iron IIner that matched the Iron cyllnder surrounding the fuel subassemblles, and the specing between the shleld subassemblles was the same as that between the fuel subassemblies.

Detalls of the grid-plate shleld subassemblites are shown In Figs. 7.6 - 7.8. The shielding conslsted of $\mathrm{B}_{4} \mathrm{C}$ that filled a space between Inner and outer steel IIners of the subassemblies. The $\mathrm{B}_{4} \mathrm{C}$ was vibra-packed to densities varying from 76.2 to 7.24 of the theoretical denslty In the GCFR, and Its thickmess varled fram $1.1 \mathrm{~cm}$ at the fuel end of the subassembly to $3 \mathrm{~cm}$ at the grid-plate end. These thlcknesses were def Ined by the thicknesses of Iron pleces at each end of the subassembly, which reduced the overall length of the $\mathrm{B}_{4} \mathrm{C}$ section to $32.3 \mathrm{~cm}$.

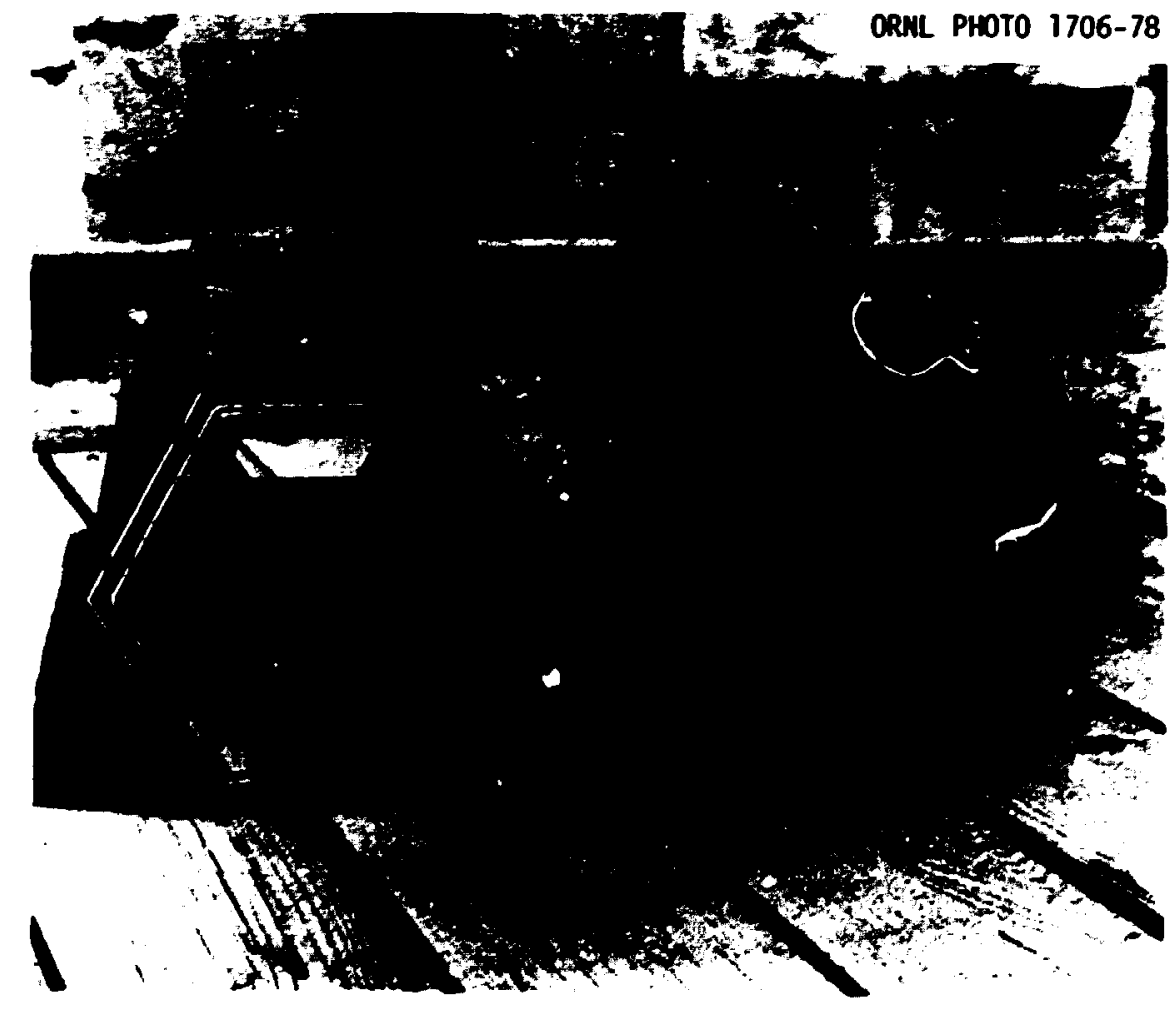

FIg. 7.6. ExperImental GrId-Plate Shlold Subassemblles: Fuel-PIn Interfoce (Left); and GrId-Plate Interface (RIght). 

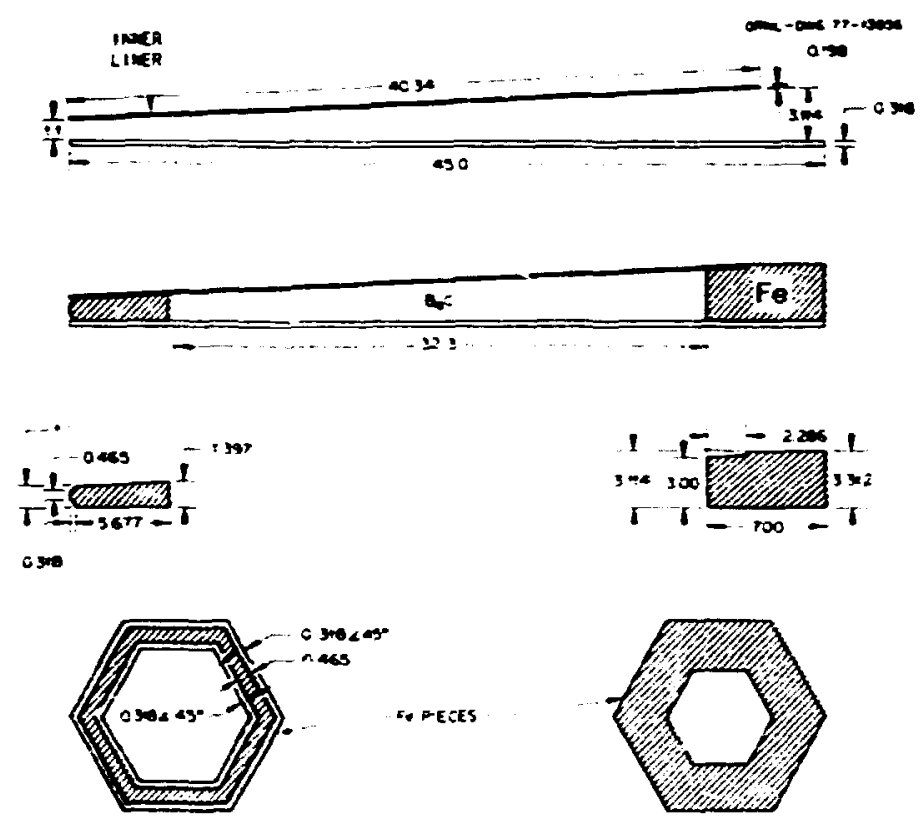

Darwion

Fig. 7.7. Schematic of Grid-Plate Shield Subassembly.

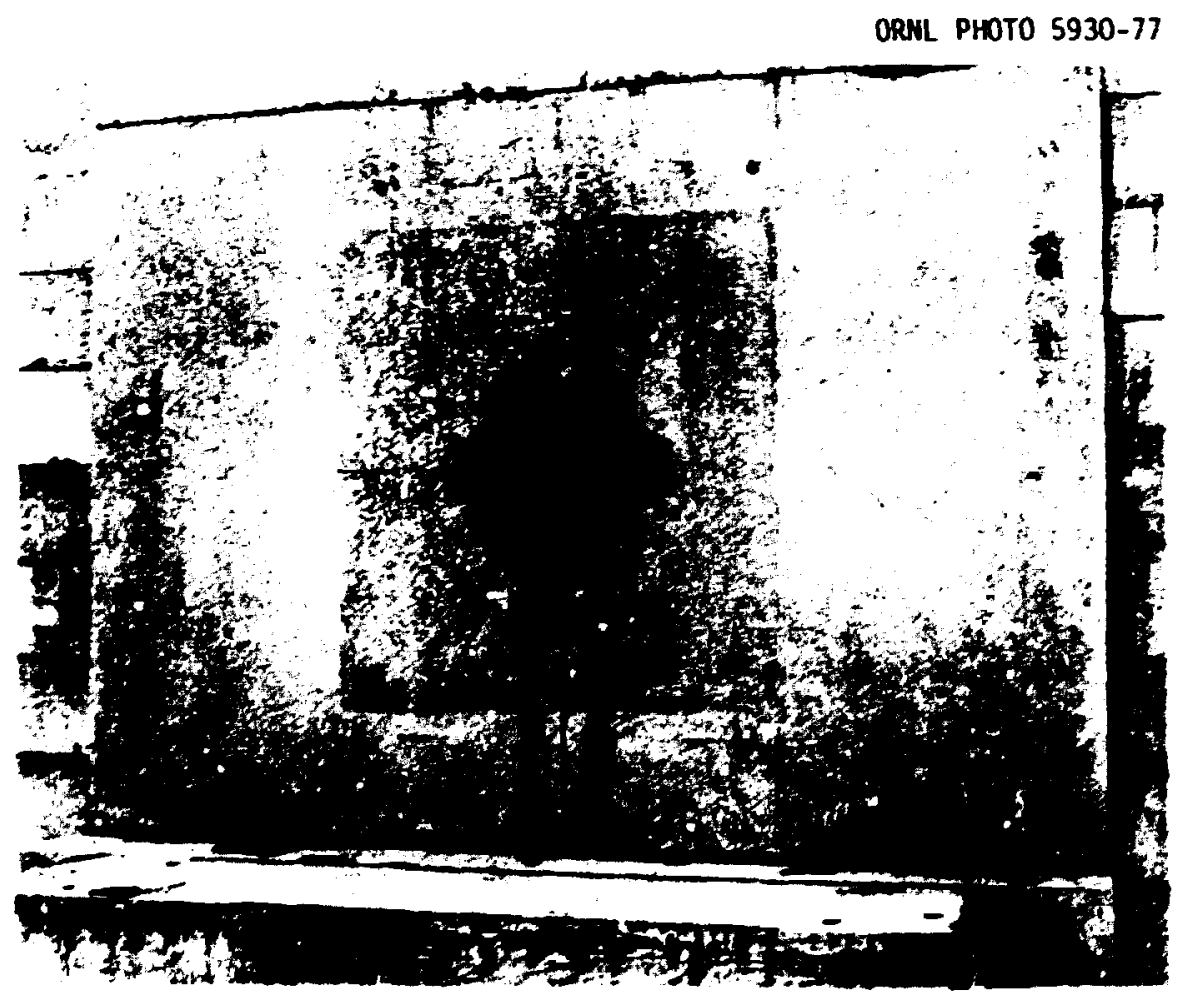

FIg. 7.8. Experimental Mockup of Seven GrId-Plate Shleld Subessemblles (Surrounded by Iron-Lined Concrete). 
The final section of the experimental configuration, the grid-p!ate simlation, consisted of a 63.5-an thickness of iron containing seven 16.5-co-dian holes whose axes coincided with the axes of the fuel and shield subassentiles (to simulate continuous passagevays for hellium coolant flow and control rod drives). Removable sleeves fliled with $B_{4} C$ fol lowed by $5.9 \mathrm{~cm}$ of Iron mocked up the portion of the GCFR grid-plate shield designed to project into the grid plate (see fig. 7.1). The 63.5-cm thickness for the grici-plate mockup was chosen to represent the 61 -cm-thick GCFR grid plate plus a $2.5-\mathrm{cm}$ thizkness of Iron as (1) a spacer to properly cusition the cylindrical sections with respect to the grid plate and (2) filler to partially simulate the thick steel section of the subassembly duct walls where a transition is made from a hexagonal shape to cylingrical shape.

A summary of the various contigurations measured in the experiment is given in Table 7.1. Spectral measurements vere made beyond the conflgurations with the TSF NE-213 spectrometer and with the TSF hydrogen counters. Other detectors used were the Hornyak button and the various diameter Bonner balls. The results of the mzasurements are compared with the calculated results in Section 7.4 below.

\subsection{DESIGN AND PREANALYSIS OF THE EXPERIMENT}

As pointed out above, the configuration describud in Section 7.2 was designed on the basis of a serles of neutron transport caiculations in which the various components were modeled. Since the configuration was to be as prototyplc as was practical, it was necessary that calculations also be performed for the GCFR proper in order to judge now well the results predicted for the experimental conf Iguration agreed with those predicted for the GCFR. Throughout the design an attempt was made to meet all the requirements set for the experiment by General Atomic.

One of the primary requirements specifled by GA was that the core section adequately resemble a semi-infinite fuel rod lattice corresponding to the actual reactor and that it have sufficient multiplication that the radiation source for the experiment would emanate primarlily from within the rods. Another was that the spacing between the fuel rods and between subessemblies of the fuel rods be varled to essentlaliy bracket the core design options under considerotion. 
Table 7.:. Descriptions of the GCFR Grid-Plate Shield Experiment Conf Igurations*

\begin{tabular}{|c|c|}
\hline Configuration & Description \\
\hline $11 . A$ & $\begin{array}{l}\text { Empty cavity bidden by concrete shadow shield and surrounded by steel- } \\
\text { lined concrete }\end{array}$ \\
\hline II.B & $\begin{array}{l}\text { II.A plus seven subassemblies spaced } 1.27 \mathrm{~cm} \text { apart and containing } 127 \\
\text { fuel pins per subassembly }\end{array}$ \\
\hline $11 . \mathrm{C}$ & II.B plus steel-lined concrete section for grid-plate shields \\
\hline II .D & II.C plus seven grid-plate shield subassenblies spaced $1.27 \mathrm{~cm}$ afart \\
\hline I!.E & $\begin{array}{l}\text { I1.D plus a } 61 \text {-cm-thick stack of iron plates located } 15.24 \mathrm{cos} \text { from the } \\
\text { grid-plate shields }\end{array}$ \\
\hline II.F & 11.D followed by the prototypic grid-plate mockup \\
\hline $111 . A$ & $\begin{array}{l}\text { I1. in plus seven subassemblies spaced } \mathrm{C} .635 \mathrm{~cm} \text { apart and containing } 127 \\
\text { fuel pins per subassembly }\end{array}$ \\
\hline III.B & III.A plus seven gric-plate shield subassemblies spaced $0.635 \mathrm{~cm}$ apart \\
\hline III.C & $\begin{array}{l}\text { Ill.e plus a } 61 \text {-cm-thi-a stack of iron plates located } 15.24 \mathrm{~cm} \text { from } \\
\text { the grid-plate shields }\end{array}$ \\
\hline IV.A & $\begin{array}{l}\text { 11.A plus seven subassemblies spaced } 1 . \overline{\mathbf{7}} \mathrm{cm} \text { apart and containing } 91 \\
\text { fuel pins per subassembly }\end{array}$ \\
\hline IV.R & IV.A plus seven grid-plate shield subassemblies spaced $1.27 \mathrm{~cm}$ apart \\
\hline IV.C & $\begin{array}{l}\text { IV.8 plus a } 61 \text {-cm-thick stack of iron plates located } 15.24 \mathrm{~cm} \text { ircm the } \\
\text { grid-plate shields }\end{array}$ \\
\hline V.A & IV.A minus seven fuel pins from the center of the central iuel sulassemis \\
\hline V.8 & IV.8 minus seven fuel pins from the center of the central fuel sutassembly \\
\hline VI.A & $\begin{array}{l}\text { 11. A plus seven subassemblles spaced } 0.318 \mathrm{~cm} \text { apart and containing } 127 \\
\text { tuel pins per subassembly }\end{array}$ \\
\hline$\vee 1.8$ & vi.A plus seven grid-plate shield subassemblies spaced $0.318 \mathrm{~cm}$ apart \\
\hline
\end{tabular}

Note that all components--fuel fin subassemblies, the grld-plate snielc subassemblies, and the grid plate--are surrounded by concrete in the radial cirection. 
In order to sinulate the axial streding of the GoFR, It wes necessary that the flux of nettrons coning directly fron the TSR-II core be eInigized, wich dictated that a shador shleld I Ike that shown In FIg. 7.1 be used tetween the reector and the sleviated GCFR fuel-blanket section. Witt: a sufficlently thick shadon shield, the uncolilided neutron source that had dainated the neasurements described In Chepters 5 and 6 could be essentlaliy elininated, and the radiation source In the experinent would lergaly consist of neutrons that were born within the sluulated GCFR core and bianket and then streend fron the core along the helliw coolant passugenays.

The first design-support calculations therefore vere perforned to estebl Ish the thickness of the shadow shleid for the exper leent end to escartaln wether edequate flux levels could be attained by adeling only seven GcFi-type fuel subessemblites. The calculations were two-rimensional DOT-IV calculations using the 51 -group GCFR cress sections and a spmetrlc 70-angle $\left(5_{10}\right)$ quadrature (ref. 1). As In Section 6, tha source for the calculations was obtained by projecting the eagular fluxes enarging fran the tailspinerIcal TSR-II onto a disk via the Maerker technlque (ref. 6). These calculations

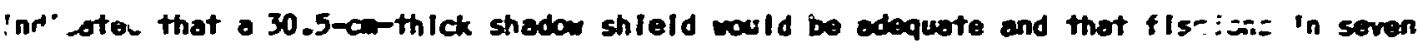
subassemb! ies of GCFR design would provlde high enough flux levels.

Subsequently the calculations were repeated for the slightly enrlched $\mathrm{NO}_{2}$ rods avallable for the experiment. These colculations, for which the 51-group cross sectio is were collepsed to seven groups and a symbtric ju angle $\left(S_{6}\right)$ quadrature was employed, showed that the fission streaning source fran the rods wovld =flll be adequate, and, ix-eover, that nearly 903 of the neutron leakege fro the p:n arroy would be due to fissions within the arroy. The calculations also Indlcated rhat while wost fissions in the fuel pin arroy would occur near the shadow shleld, the flsslons that occurred near the grid-plate shle!d (1.e., : irhin the axial blanket) would be wore Inportant in providing a grid-plate shleld source.

Concern abut the effect if a verlable water content In the concrete on the noutrons scettering into the pin array, and therefore on the fissions produced in the array, prompted another seven-group $S_{6}$ calculation, which showed the effect would be winlins!.

-A comparlson of 51-group and 7-group results showed that the coerse-group calculatlons were adequate for determining integral quantitles, such as total fission source and total neutron leakege, but not for predicting energy distrlbitions. 
A HIrd calculation Investigated the radial distribution of fissions within the cluster of fuel pin subassebiles. The distribution wes found to paik significantly of the outside edge of the cluster, Wich would not fulfill the semi-infinite lattice requirenent, bert the distribution becese flatter es the thlckness of a steel IIner surrounding the subessublles and IIning the concrete ves Increased louling to absorption of theral nutrons In the steel). With the IIner thicknesses finally selected, the flux stIII peeked but because of an appareat redistribution of the nautron population through scattering collisions, the flux Inplinging on the grid plate shield was predicted to be reletively flat.

Another set of celculations concentrated on the datalis of the design of the gridplate shiald subessamblies. Bacause a thinaer steal casing wes beling usad for the exper lantal shield subessabl les then would be used In the CorR sebassablies, the totol 8,C volue In the experimental subessemblles exceveded that In the GCFR proper, but the less dense pecking of the $\mathrm{B}_{4} \mathrm{C}$ In the exper Imental conf Iguration was found to be a conensating factor. The calculations Indicated, however, that the B,C sleves shown In Fig. 7.1 should be Included In the conflguration; the sleeves wuld be present In the cylindrical end section of the GCrR fuel subessembly and their absence In the exper Iment vould have drastically altered the measured results and thelr relevance to the GCrR. The use of steal sleoves In the experiment was considered, but the calculations Indlcated that with the steel sleeves the noutron flux energing from the grld plate would be 403 nigher than It would be with the B,C slecres.

Calculations were also performed to predict how varlations In the vlaths of the gaps between the fuel and shield subessemblies would afrect the meosurenonts. It had bean specifled that gap widths of 3.2, 6.4, and 12.7 an should be used, but It was faered that as the gap width was decreased, nutron streaing between the outer surfece of the pln orrar and its surrounding steel IImer alght cominate the mosurements. The calculations Indicated that when the grid plate was not present, the perlpherel gap would have no not leable effect

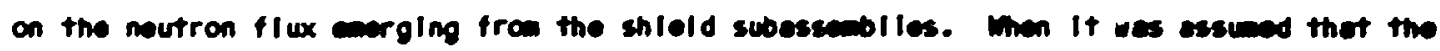
! IrId plate wes In position, nowever, the flux Ieving the shleld subessublles Incresed

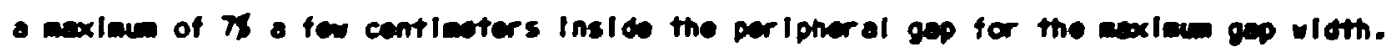
Thls difference did not apper to verrent plugging of the aep in the exper lant.

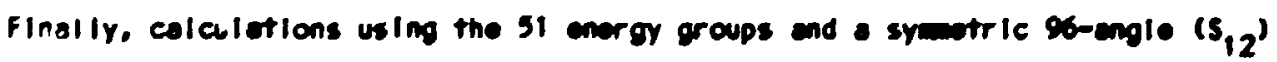

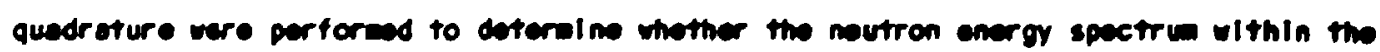


experimental essembl. would be prototyplc of a GCFR-type spectine, especlally in the grid-plate shield and grid-plate reglons. Comarisons of calculatel spectra incidant on and exiting from the grid plate for the expericontal conflguration (9) , ins $r$. subassem Iy) and the GCFR des!gn (lowpressure-drop, beglnning-of-1 Ifo cese) are shown In Fig. 7.9. While the spectra of the experimental essembly are slightiy herder, It vas concluded that the exper Inental spectra resembled the GCFR sfectra sufficlentiy to provide relevant and interpretable data.

\subsection{MUYYIS OF THE DPERIVEMT: COMPARISON OF CALCULATED} ND MEASURED RESUTS

Table 7.1 lists a total of 16 experimental configurations. Of these, elght were exained in derall during the fInal analysis of the experinent, the analysis being carrled out concurrentiv with the easurements and axtending Into ear Iy 1979. The specific configrrations for which calculations vere performod vere the empty cavlty configuration (II.A). four configurations extending through the fual-pin section (II.B, III.A, IV.A and VI.A), two configurations extending through the gria-plate shield section (II.0 and IY.Q), and Tr.e final configuration that included the grid-plate nockup Itse f (II.F). In addition, soce iaferencer were made frow the neasured results for other configurations.
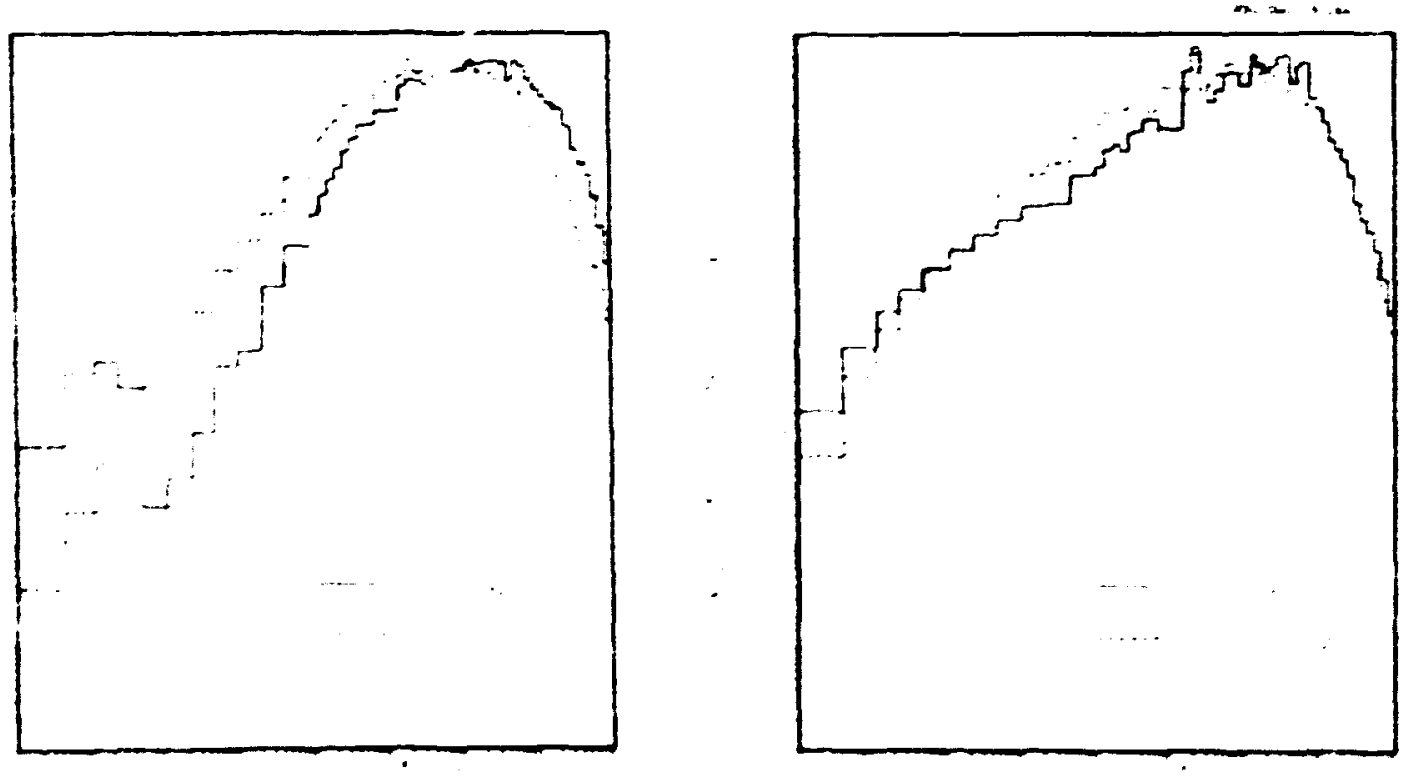

Fig. 7.9. Comporison of Noutron Spectra Calculated for the TSF Experimantal

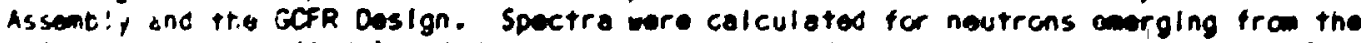
grlo-plate inield (left) and for neutrons earging from the grlo plate (rlght). The TSF calculation included 91 pins der assembly and the prototyole grlo plate: the GCrR calculation was for the low-pressurodrop beginning-of-lite deslgn. 


\subsubsection{Dofinition of Source}

As hes been pointed out in the discussion above, the penetrating radiation source for the grid-plate shield design confirmation experiment consisted almost entirely of meutrons born from fissions in the fuel pIns slaulating the GCFR core, the contributlon froe direct TSR-II neutrons being reduced by the insertion of a thick concrete shadou shield In the TSR-II bea atread of the figel pins. The bean was thus dIracted around the shador shield and forced into a near perpandicular Incldance onto the fuel pins.

In the analysIs the initial TSA-II "or Iver" source ras obtained in the sane manner as has bean cescribed In Chapters 5 and 6 . That is, the angular fluxes emergIng fron the healspherical surface of the TSR-II taak were projected onto a dIsk-sheped source by 2 technlque simllar to Nearker's (ref. 6), the location of the disk beling at the inner surface of thF'liarge-bea collilatar as shown In Flg. 5.3. ThIs source vas then used as the input source for a two-dimonsional discrete ordinates 00T-3.5 calculation to determine the tIrst of a serles of Internal bound ary sources that would be used as input sources throughout the analysis. The tro-dimensional gecmetry extended through the bea collibator and on through the shacor shleld, so that the internal boundary source, wich was output in the plane including the inner surtace (reactor side) of the shadon shield, wold include the ef fects of beckscattering fran the snadon shleld.

The resulting output boundery source wes then used as the input source for a iransport calcu.ation extending through the fuel-pin section of the experimental contiguration. Siallarly, an internal bouncary source output fram the calculation for the fwel-pIn section was used as the input source for a trensport celculation through the grlaplate snleld section, and so forth.

The InItlal source calculation used the 51 -group GOFR cross sectlons with $P_{3}$ expension and the Iso-angle quadrature set. 's the analysls propressed through the configuration, any changes in the engular quearature and spatlel washes required betwean succesing celculations were effected with the FACT code."

The FACT code wes witten for use vith DOT-III; therefore, boundery sources output fram DOT-IV hed to be preprocesesd bofore beling Input Into FACT. Conversely, output sources fro FACT hed to be postpresessed before boing Input into Dot-IV. 


\subsubsection{Trensport Calculations for Empty Cavity Configuration}

The empty cavity configuration, shown in Fig. 7.10, is described in Table 7.1 as Configuration II.A. In the experiment messurements vere mode both along the axls of the catity and along a radial traverse $30.5 \mathrm{c}$ behind the concrete shleld containing the cavity. In addition, masurements vere made at a point approximately 244 ca beh ind the configuration as a check on the caiculations of the energing neutron spectru.

Calculations for this configuration were performed with the discrete ordinates corb Dot-IV (two dimensions, 51 meutron groups, $P_{3}$ cross sections, and the 150-direction blased quadrature set) and wth the Monte Carlo code mORSE. Comparisons of the calculated and masured Borner ball and Hornyak button responses along the cavity axis are shown in Fig. T.11, were the sketch of the surrounding vold and concrete at the sotton of the figure ofds in identifying the relative locations of the masurewents.

f'gure 7.11 shows thit except for the point nearest the shadow shleld, the DOT and MORSE results agree with each other and that they agree in shape with the measured results. However, the calculated responses are higher in magnitude than the measured responses: by $45 \%$ for the Hornyak button, by 308 for the L-In. Bonner ball (cadmilumcovered), and by 55 for the 5-Ir. Bonner ball, all of whlch exceed the desired maximum discrepancy of $20 \mathrm{~s}$. The same trends were observed for the radial traverses at $30.5 \mathrm{~cm}$; and for the measurements at $244 \mathrm{~cm}$, the calculations overpredicted 3-, 6-, and 10-in. Bonner ball count rates by factors of $1.52,1.46$, and 1.40 , respectively.

Since the MORSE and DOT results were in general agreenent, the discrepancy detween the calculated and masured results would appear to lie within a common infut, such as the description of the concrete composition, the DOT-generated source used in both calculations, etc. In an attempt to resolve the discrepancy, several additional calculations were performed, the first being to repeat the Dor calculations with a symatric 96-angle $\left(S_{12}\right)$ quadrature substltuted for the 150-angle bl: ed quadrature. The calculated results remelned essentlally unchanged, hovever.

Ne, $t$, a sensitivity analysis was performad for the s-in. Bonner ball response at $30.5 \mathrm{~cm}$ trom the end of the conflguration, using the VIP cude and the FORSS system. This analysis showed that the count rate was wainly sensitlive to the water content in the concrete, pertlcularly the concrete of the shadow shiefd. 


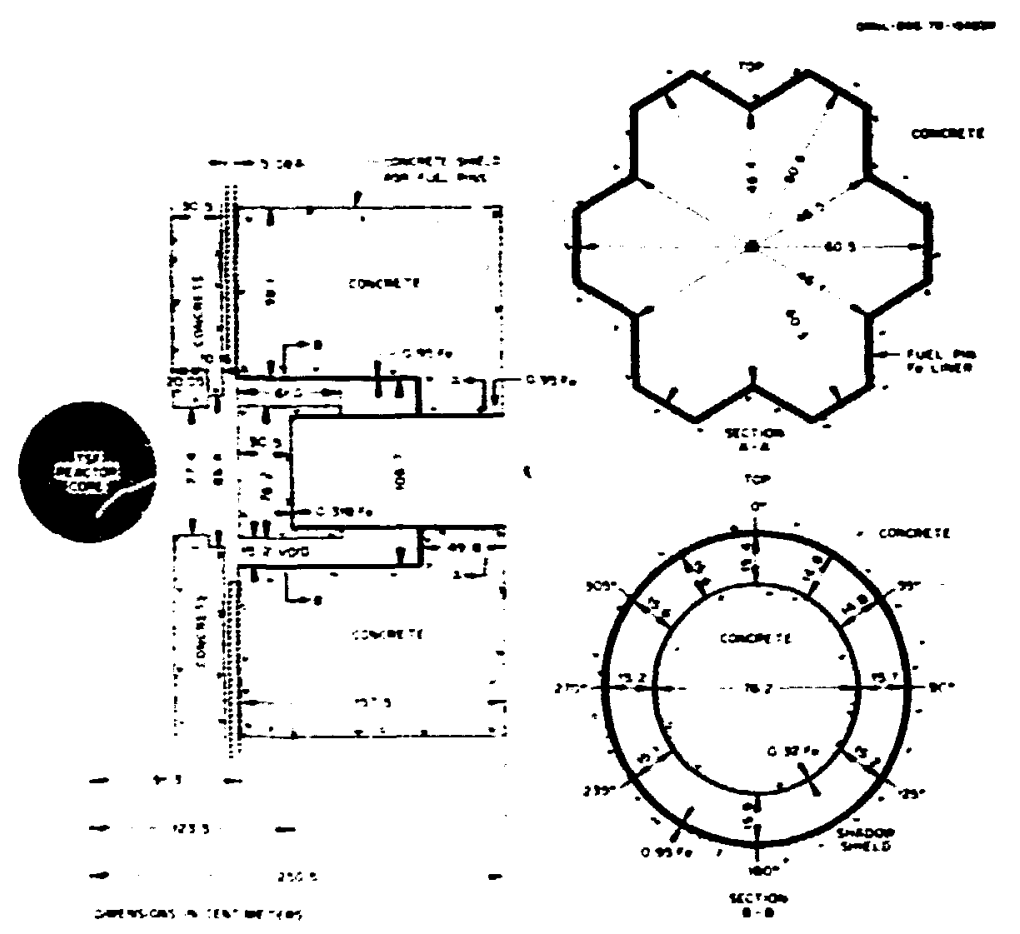

Fig. 7.10. Empty Cavity Contiguration (Showing 30.5-cm Thick Concrete Shadow Shleld and Surrounding Concrete).

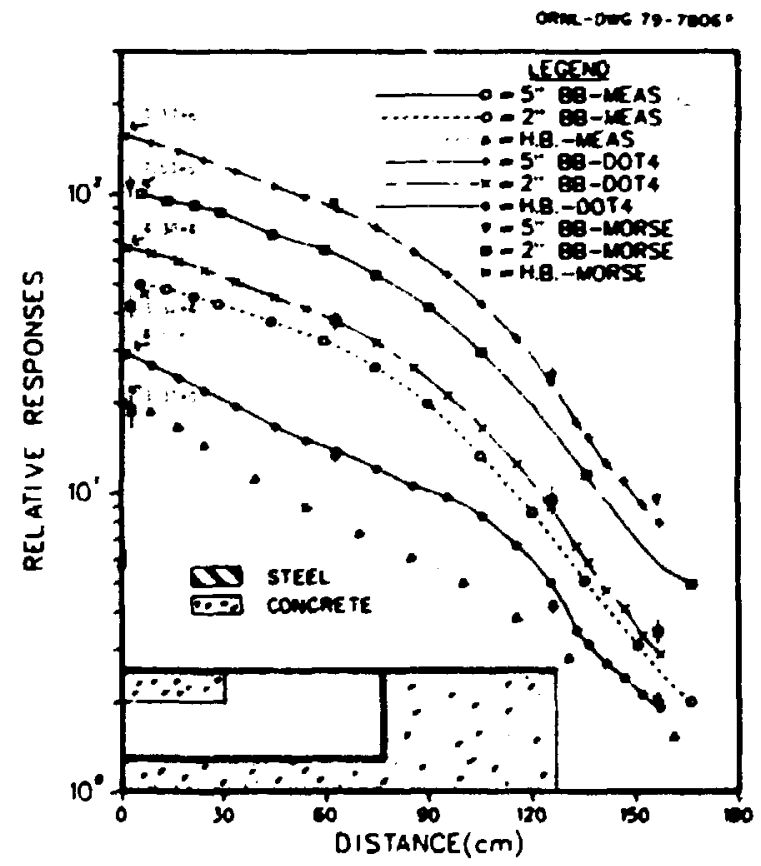

Fig. 7.11. Relative Meesured and Calculated Detector Responses Along Axial Traverses In Empty Cavity Conf Iguration (II.A). BB = Bonner ball response (counts/min.W), HB =

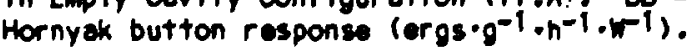


In order to Investigate the effect of the concrete compositian further, the percent changes in the ato densities of the elemental components of severai congreto alxes tra the aton densities assuned in the enalysis were multiplied by the computed sensitivity coefflcients. The results, presented in detall in rcf. 5, Indicated significant changes in the resoonse of the 5-in. Bonner ball with changes in the concrete composition. This observation was supported by seven-grosp calculations ron for the various concretes; however. the only conclusion that could be daduced fran these calculations is that a knowledge of the concrete composition is very important for eccurate calculations of this configuration.

The forward and adjoint calculations from the sensitivity analysis were also used to produce a channel theory plot that showed the flow of inportant meutrons (contributons) through the configuraticn. This plot revealed thet the wajor fiom was around the sinadur shleld, as was Intended. To test whether the mesh used for the shadou shleld was adequate, additional forward calculations were performed with seven energy groups using both the origiral wesh and a wesh in which the Intervals were joubled in both the radial direction and the axlal direction. The results from the two calculations differed ittile from each other or tron the earller 51 group results. Thus, the zause for the discrepancles between the calculeted and measured resui-s was not definitely established.

\subsubsection{Transport Calcul, tions for fuAltin Contigurations}

The fuel-fin confligurations included in the experiment, that is, the configurations containing only the simulation of the GCFR fucl and axlal blanket (see Fig. 7.1), are those IIsted in Table 7.1 as II.B, III.A, IV.A, V.A and VI.A. The ditferences anong these configurations are In the number of fuel plins used per subessemoly and in the spacing betwean subassemblles (sea in Table 7.2). As noted cerller, the range of spacings was selected to cover the deslgn options under consideration for the GCFR. Configuration V.A was a speclal case In that soven fuel plins were removed from the center of the central subassemoly to simulate a control-rod channel.

Wote: The composition for concrete used In this onalysls wes the "standerd TSF concrete" (see Toble 10.2 In Chapter 10). 
Table 7.2. Fuel and Subassembly Arrangements in Fuel-Pin Conflgurations

\begin{tabular}{cccc}
\hline Configuration & $\begin{array}{c}\text { Subasseabiy } \\
\text { Sparing }\end{array}$ & $\begin{array}{c}\text { Fuel Pins per } \\
\text { Sebassembly }\end{array}$ & $\begin{array}{c}\text { Total Number of Fuel } \\
\text { PIns }\end{array}$ \\
\hline In Configuration \\
II.B & $1.27 \mathrm{~cm}$ & 127 & 889 \\
IV.A & $0.635 \mathrm{~cm}$ & 127 & 889 \\
V.A & $1.27 \mathrm{co}$ & 91 & 637 \\
VI.A & $1.27 \mathrm{~cm}$ & 917 & 6305 \\
\hline
\end{tabular}

- Oniy a fuel pins in central subassembly, seven fuel plins having been removed from the center of the subasseably to simulate a control-rod channel.

This first section of the experimental configuration was studied In considerable cetall for several reasons. First, It was necessary to define the source leaving the axlal blanket reglon and entering the gritiplate shleld region and, moreover, to deterwine whether that source could be accurately calculated. Successfully calculating the source not only was essentlal to the analysis of the cull experimental conflgurjtion but also would indlcate that the source leaving the axlal blanket region of the GCFR proper could be calculated. Studying these configurations al so provided an additlonal Oppartunity to examine neutron streaming In GCFR-type fuel-pIn lattIces, this tIme in the absence of an overpowerIng "uncollided" source that originated outslde the fuel pins (as occurred In the experiments described in Chapters 5 and 6). Finally, being able to compare the results for the different fuel spacings walld especlally provide Inslght Into the streanling mechan Ism.

In the experlment, Bonner ball and Hornyak button measurements were made along an axlal traverse behlnd each configuration and also along radial traverses beyond Contiguration II.B. In addition, NE-213 and hydrogen counter spectral measurements wer. made behind Contlguration II.B.

Two-dimensiona: discrete ordinates calculations (51 groups, $P_{3}$ cross sections, 150angle blasec quadraturel were performed to obtaln calculated detector responses for all the fuel pin configurations except Conflguration V.A, whlch was not analyzed. ThreoOlmensional Monte Carlo calculations were performad for Conflguration II.B only. 
For points out to $30.5 \mathrm{~cm}$ beyond the conflgur atlons, the two-diaenslonal calculations used the Dot-IV code alone, but for distant points (specifically, at 138.1 Can and 305 an beyond the configurations) the DOT results through the conf Iguration were transported on to the detector point via the DISKTRW code. In al! these calculations the fuel-pin region was modeled as concentr! : annull of vold, fuel, steel, etc. The major boundarles were determined by the elghteen outer steel valls surrounding the outer subassemblles and the six (double) interlor walls around the central subassembly. The reaining twelve walls were assuad to be Intimately aixed with the fuel pins of the outer six subasseablies, the fuel reglons beling divided, according to their respective volume fractions, into al ternating ruel and vold rings.

For the MDSE calculation of Configuration II.B, a 1/12th segwent of the gecmetry was mocked up almost exactly, with cladding and fuel reglons included for each pin. The MORSE calculation was actually a comblination of two calculations, one in which the boundary source generated by the DOT calculation was used as a fixed source and another in whlch the fission density distribution in the fuel pins calculated oy DOT was used as a fixed source. The results were comblned by multiplying the separate results for a unlt source by the total source for each and adding the two results. The DOT sources were used because It would have been extremely difficult for MORSE to converge the fission source in the presence of the fixed boundary source.

Comparisons of the DOT-calculated and measured Bonner ball and Hornyak button responses on the axls $30.5 \mathrm{~cm}$ beyond the four analyzed fuel-pin conflgurations are shown In the upper half of Table 7.3, along with the measured values for Configuration V.A. SImilar comparisons of the DOT/OISKTRALCalculated and measured responses on the axis 305 an beyond the configurations are shown In the lower half of Table 7.3. It is apparent that for on-axis detector locations close behind the configurations, the DOT-calculated results agree well with the measured responses of both the 2-In. cadmlum-covered Bonner ball and the 5-ln. Bonner ball. The calculated results for the Hornyak button, however, are 358 to 703 higher than the measured responses. Compar I sons of the radial traverses at $30.5 \mathrm{~cm}$ beyond Configuration 11.8 show the same trends.

Comparlsons of the DOT/DISKTRAN-Calculated and measured Bonner ball responses on the axis $305 \mathrm{~cm}$ beyond the fuel-pin conflgurations (see lower nalt of Table 7.3 ) do not show 
Table 7.3. Comparison of DOT-Calculated and Measured Detector Responses on AxIs $30.5 \mathrm{~cm}$ and $305 \mathrm{~cm}$ Beyond Yarious Fuel-PIn Conflgurations

\begin{tabular}{|c|c|c|c|c|c|}
\hline \multirow[b]{2}{*}{ Detector } & \multicolumn{5}{|c|}{ Confliguration } \\
\hline & $(11.27 .127)=$ & $\begin{array}{c}111 . \AA \\
(0.635,127)\end{array}$ & $\begin{array}{c}1 V . A \\
(1.27,91)\end{array}$ & $(1.27,91 \div)$ & $\begin{array}{c}v 1 . A \\
(0.318,12)\end{array}$ \\
\hline \multicolumn{6}{|c|}{ Response at $30.5 \mathrm{~cm}$ Beyond Configuration } \\
\hline \multicolumn{6}{|c|}{ 2-in. Cd-covered boll } \\
\hline $\begin{array}{l}\text { Calculated } \\
\text { Measured } \\
\text { Calc./Meas. }\end{array}$ & $\begin{array}{l}8.30+1 \mp \\
8.80+1 \\
0.94\end{array}$ & $\begin{array}{l}8.48+1 \\
8.63+1 \\
0.98\end{array}$ & $\begin{array}{l}1.17+2 \\
1.43+2 \\
0.82\end{array}$ & $1.46+2$ & $\begin{array}{l}8.43+1 \\
8.69+1 \\
0.97\end{array}$ \\
\hline \multicolumn{6}{|l|}{ 5-In. Dall } \\
\hline $\begin{array}{l}\text { Calculated } \\
\text { Measured } \\
\text { Calc./Meas. }\end{array}$ & $\begin{array}{l}8.53+3 \\
8.53+3 \\
1.0\end{array}$ & $\begin{array}{l}8.38+3 \\
7.95+3 \\
1.05\end{array}$ & $\begin{array}{l}1.18+4 \\
1.25+4 \\
0.94\end{array}$ & $1.29+4$ & $\begin{array}{l}8.15+3 \\
7.88+3 \\
1.03\end{array}$ \\
\hline \multicolumn{6}{|c|}{ Hornyak button (ergs/g-h-w) } \\
\hline $\begin{array}{l}\text { Calculated } \\
\text { Measured } \\
\text { Calc./Meas. }\end{array}$ & $\begin{array}{l}4.18-2 \\
2.99-2 \\
1.40\end{array}$ & $\begin{array}{l}4.10-2 \\
2.55-2 \\
1.61\end{array}$ & $\begin{array}{l}6.39-2 \\
4.75-2 \\
1.35\end{array}$ & $4.24-2$ & $\begin{array}{l}3.97-2 \\
2.34-2 \\
1.70\end{array}$ \\
\hline \multicolumn{6}{|c|}{ Response at $305 \mathrm{~cm}$ Beyond Configuration } \\
\hline \multicolumn{6}{|c|}{$\begin{array}{l}\text { Bonner ball Ccounts/min or } \\
\text { 2-in. Co-ccvered ball }\end{array}$} \\
\hline $\begin{array}{l}\text { Calculated } \\
\text { Measured } \\
\text { Calc./meas. }\end{array}$ & $\begin{array}{l}6.32+0 \\
4.32+0 \\
1.46\end{array}$ & $\begin{array}{l}6.39+0 \\
3.28+0 \\
1.95\end{array}$ & $\begin{array}{l}8.87+0 \\
7.28+0 \\
1.22\end{array}$ & $7.21-0$ & $\begin{array}{l}6.45+0 \\
3.61+0 \\
1.79\end{array}$ \\
\hline \multicolumn{6}{|l|}{ 5-in. ball } \\
\hline $\begin{array}{l}\text { Calculated } \\
\text { Measured } \\
\text { Calc./Meas. }\end{array}$ & $\begin{array}{l}4.65+2 \\
3.48+2 \\
1.34\end{array}$ & $\begin{array}{l}4.96+2 \\
3.16+2 \\
1.57\end{array}$ & $\begin{array}{l}6.68+2 \\
5.30+2 \\
1.26\end{array}$ & $5.30+2$ & $\begin{array}{l}4.91+2 \\
3.03+2 \\
1.62\end{array}$ \\
\hline \multicolumn{6}{|c|}{ Hornyak button (args/g-h/w) } \\
\hline $\begin{array}{l}\text { Calculated } \\
\text { Maasured } \\
\text { Calc./Meas. }\end{array}$ & $\begin{array}{l}2.87-3 \\
1.68-3 \\
1.71\end{array}$ & $\begin{array}{l}3.13-3 \\
1.43-3 \\
2.19\end{array}$ & $\begin{array}{l}4.71-3 \\
2.75-3 \\
1.71\end{array}$ & $2.79-3$ & $\begin{array}{l}3.09-3 \\
1.35-3 \\
2.29\end{array}$ \\
\hline
\end{tabular}

$-(1.27 .127)$ injlcates $1.27 \mathrm{~cm}$ between fuel subassemblles, 127 fuel pins per subassembly.

Only as fuel pins in central subassembly.

$I_{\text {Resd }} 8.30 \times 10^{!}$. 
a simllar agreement. All the calculations substentially overpredict the measurements, the results for the Hornyak button again reflecting the greatest disagreement. The radial traverses beyond Configuration $11 . \mathrm{B}$ at $305 \mathrm{~cm}$ showed that the overprediction decreased as the detectors moved away from the axis (that is, from the line-of-sight of the fuel latticel, but only in the case of the 5-in. Bonner ball did the calculations approach the measurements and then only for of f-axls locations greater than $40 \mathrm{~cm}$. In general, the overpredictions appeared to be greatest for those fuel lattices having the highest fuel density.

Since the 5-in. Bonner bali has a response nearly proportional to the tcital neutron flux, intercomparing the 5-in. Bonner ball responses for the fuel-pin configurations indicates the effect of the fuel spacing on the transaltted flux. Teble 7.3 shows that for the 30.5-cm location, increasing the subassembly spacing from $0.318 \mathrm{~cm}$ io $1.27 \mathrm{~cm}$ (that is, going from Configuration V!.A te Configuration II.B) Increases the calculated 5-in. Bonner ball response by 58 and the measured response by $8 \%$.

Comparing the Hornyak button measurements (fast neutron fluxes $>0.1$ MoV) for Configurations IV.A and $I I .8$ Indicate the effect of the vold fraction within the fuel assemblies on the $\mathrm{hig}$ :-energy transport. At $30.5 \mathrm{~cm}$, the measured value for Conf:guration IV.A, whlcil had a vold fraction of 60.28 , is higher by a factor of 1.6 than the measured value for Configuration II.8, which had a vold fraction of 44.5\$. The difference is due both to a lower effective materlal density and to Increased streaming in Configuration IV.A. The calculations indicated that the scattering and fission sources per unlt volume of materlal within the fuel subassemblles were nearly the same In the two assemblles.

While calculations were not performed for Conflguration V. $A$, comparing the measured values for the configuration with those for Configuration IV.A shows that removing the seven central fuel pins from the central fuel subassembly (to simulate a control channel) increased the total fluxes (as deduced trom the 5-In. Bonner ball responses) by $3.5 \%$ at both the 30.5-cm location and the 305-cm locotlon. On the other hand, removing the seven fuel pins decreased the fast-neutron fluxes las deduced from the Hornyak button responses) by 115 of the $30.5-\mathrm{cm}$ location and Increased them by 1.55 at the $305-\mathrm{cm}$ location. This Implies that the grid-plate shield (and grid plate) would have a lower 
fast-neutron exposure with a control subassembly in place, and thus using the fastneutron exposure obtained with a full fuel subassembly for design purposes would be the most conservative approach. On the other hand, the percentage Increase in the total flux with the channel open is probably greater than it would be in the GCFR since the experiment had an invard flux gradient that drove the neutrons into the streaming channel (that IS, TSR-il neutrons vere scattered Into the channel and also fission neutrons produced In the pins were backscattered from thie shadow shield (nto the chaniel).

Another observation apparent from the tables is that, in general, the calculatedto-measured ratios for ail the detectors appear to increase with a decreasing subassembly spacing and to decrease with a decreasing number of fuel pins.

The Monte Carlo calcuici ions for Configuration 11. . were pertormed for detector locations 0,20 , and $40 \mathrm{~cm}$ off the axls for both of the radial traverses lat 30.5 and $305 \mathrm{~cm}$. For the 5-in. Bonner ball the Monte Carlo -esponses at $30.5 \mathrm{~cm}$ were in good agreement with both the DOT responses and the measured responses, the statistical mean of the Monte Carlo responses being 3 to $58 \mathrm{higher}$ than the measured responses. For the 2-in. cadmium-covered Bonner ball, the Monte Carlo calculations were 4 to $74 \mathrm{hIgher}$ and for the Hornyak button they were 18 to $218 \mathrm{hIgher}$. The differences vere larger at $305 \mathrm{~cm}$, the calculated response being higher than the measured response by 6 to 228 for the 2-in. Borner ball, by 4 to 218 for the 5-in. Bonner ball, and by 27 to 648 for the Hornyak butt in (278 on the $3 \times 15$ ). The persistent disagreenent of all the calculations with the Hornyak button measurements was viewed as a normalization problem with the Hornyak button response function.

Finally, the DOT-calculated and measured neutron spectra at an on-axis location 138.1 an beyond Configuration II.B ore compared in FIg. 7.12. The measured spectrum is a combination of ME-213 spectrometer measurements $(0.8$ to $15 \mathrm{MeV})$ and hydrogen counter measurements $(0.08$ to $1.5 \mathrm{MeV})$. As is apparent, the measured and calculated spectro were found to be in good agreement. Not unexpectedly, it was also found that when the measured fluxes were integrated over energy above $0.9 \mathrm{MaV}$ and above $0.12 \mathrm{MeV}$, the measured fluxes and the corresponding calculated fluxes were again in agreenent. In addition, calculated-to-measured ratlos for 3-, 6-, and 10-in. Bonner balls at the 138.1-cm location were acceptable $(1.27,1.16$, and 1.08, respectively). This 


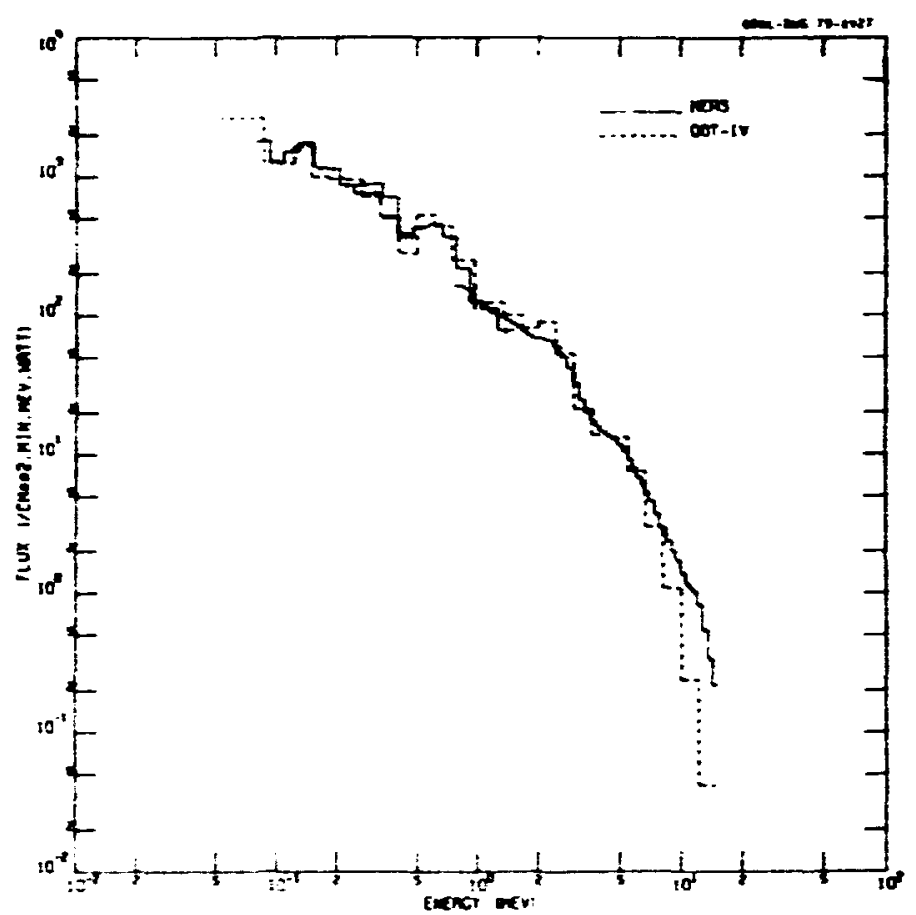

Fig. 7.12. Comparison of Calculated and Measured Neutron Spectra on the Mxis $138.1 \mathrm{~cm}$ Beyond Fuel-Pin Configuration II.B.

demonstrated ablilty of the DOT code to calculate the high-energy neutron fluxes for all these detectors again indicates a normal Ization problem for the Hornyak button (see above).

Fron the preceding it is apparent that, except for the Hornyak button responses, the calculated detector responses for distances out to epproximately $140 \mathrm{~cm}$ vere in good agreement with the measured responses. However, the disagreement at the detector position of $305 \mathrm{~cm}$ remalned. In an attempt to pinpolnt the discrepancy, a second DOT/DISKTRAN calculation was performed for the 305-cm detector location beyond Configuration II.B using only seven energy groups but eaploying a finer mesh in the fuel-pin reglon. The result was a calculated 5 -in. Bonner ball count rate that was oniy Iis higher than the mesured count rate on the axis and $135 \mathrm{higher}$ off the axis. It was concluded therefore that Inadequate mesh specing in the earller calculations was the major source for the discrepancles. On the other hand, the mesh spacing appeared to be adequate for calculations through the conflguration, which meant that the boundary source that was to be obtalned from this calculation for the succeeding calculation for the grid-plate shleld mockup should be adequate. 


\subsubsection{Transport Calculations for GrId-Plate Shleld Configurations}

The grid-plate shield configurations included in the experiment are those IIsted in Table 7.1 as II.D, III.B, IV.B, V.B, and VI.B. LIke the fuel-pIn conflgurations discussed in the preceding section, they differed in the spacings between the fuel subassemblies (whlch, of ccurse, determined the spaclings between the shleld subassemblies) and In the number of fuel plns used per subasseably. These differences are noted In Table 7.4 .

Tsivio 7.4. Fuel and Subassembly Arrangements In GrId-Plate Shleld Conf Igurations

\begin{tabular}{cccc}
\hline Conflguration & $\begin{array}{c}\text { Fuel and Shield } \\
\text { Subassembly } \\
\text { Spacing }\end{array}$ & $\begin{array}{c}\text { Fuel Pins per } \\
\text { Subassembly }\end{array}$ & $\begin{array}{c}\text { Total Number of Fuel } \\
\text { PIns in Conflguration }\end{array}$ \\
\hline II.D & $1.27 \mathrm{~cm}$ & 127 & 889 \\
III.B & $0.635 \mathrm{~cm}$ & 127 & 889 \\
IV.B & $1.27 \mathrm{~cm}$ & 91 & 637 \\
V.B & $1.27 \mathrm{~cm}$ & $91 *$ & 630 \\
VI.B & $0.318 \mathrm{~cm}$ & 127 & 889 \\
\hline
\end{tabular}

*nly 84 fuel pins in central assembly, seven fuel pins having been removed trom the center of the subassembly to simulate a control-rod channel.

The $t$ Irst configuration measured in the grid-plate shleld serles was actually Configuration II.C, which Included the Iron-IIned concrete of the grid-plate shield section of the mockup but did not Include the seven shleld subassemblles (see Fig. 7. I). The subassemblies in the fuel-pin section were spaced at $1.27 \mathrm{~cm}$ ano contained 127 pins each. On-axis measurements were made $30.5 \mathrm{~cm}$ beyond the conflguration to provlde data check polnts for the analysis. The results were $5.78 \times 10^{1}$ and $4.11 \times 10^{3}$ counts/min.h for the 2-In. cadmlun-covered Bonner ball and the 5-In. Bonner bell, respectively, and $1.09 \times 10^{-2}$ ergs/g.h.W for the Hornyek button.

Conflguration 11.0 was formed by Inserting the shleld subassemblles, which, Ilke the fuel subassemblles, were spaced $1.27 \mathrm{~cm}$ apart. Bonner ball and Hornyak button masurements were made along radial traverses Immedlately behind the conflguration and 
at locations of 30.5 and 305 an beyoni the configuration. In addition, measurements verte made along an axial traverse that extended from the outer edge of the fuel section through the shleld section and out to $30.5 \mathrm{~cm}$ bevond the zonf iguration. Slailar measurement; were made for the otier shield mockup configurations, except that the only other configuratiu. for wilch an axial traverse ws perforwed was configuration Y.B.

The ana!ysis of the grid-plite shie!c confizurations was limited to Configurations II.D and IV.8, which used 4.2 same subassembly spacing but ditfered in fuel pin density. Calculations were performed with the two-ulmensional LTT code (and COT/DISKIRAN) sor both. configurations (51 groups, 156-direction quadrature) and if the three-dimensional MORSE code for Configuration il.D.

For ine two-dimensional calculations, the tapered hex-shaped shields shown in. Figs. 7.6 - 7.8 were converted to cylindrical stepped-shaped shields as shown in Fig. 7.13 . In the model the outer liners were maintalned as distinct reglons, but the inner liners were homogenized, ith the $\mathrm{E}_{4} \mathrm{C}$. For the MORSE calculation a 1/12th segment of the sh!eld reg!on was mocked up exactiy.

Tive source for thie DOT calculations was an Inter nal boundary source output fram the approprlate fuel-pin calculations (see Section 7.3.3) at a lordtion $64.5 \mathrm{~cm}$ from the end of the fuel pins. The source for the MORSE calculation was the DOT-calcula ed angular flux $2.5 \mathrm{~cm}$ from the end of the fuel pins for Configuictio: II.B.

A comparison of the calcuiated and measured Hornyak button responses along the rad!al traverse close behind conilg sration 11.0 is shown in Fig. 7.14 and the correspondi:ig comparison for the 2-in. cadmlum-covered Bonner ball responsos is shown in FIg.7.15. The purpose of these traverses was to determine the extent of local peaking of the fluxes chat woc. I Imp nge on the grid plate, the Hornyak button largely detecting hlgh-energy neutrons and the 2-In. cadmlum-covered Bonner bail largely detecting lowenergy neutrons. The lower sketch in the tigures shows a portlon of the end of the actual experimental configuration, and the upper sketch shows a pcit'on of the corrusponding geometry assumes In the calculation. Because the volded cylindrical annulus used in the calculational model for the outer shield subassembiles extended 


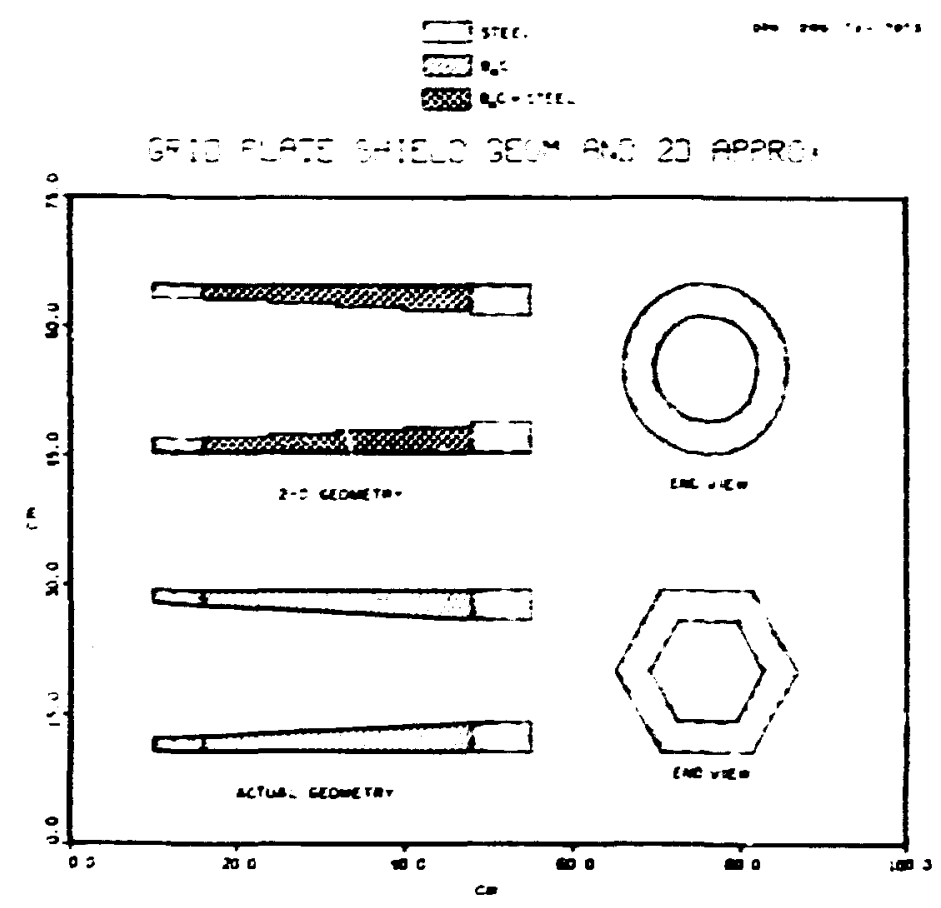

Fig. 7.13. Comparison of Actual Gridflate Shiels secmetry and a Two-Dimensional Approximation to That Geomery. (The tapered portion of the sh!e is is first approximated by steppes hexagons and tr. converted to stepped cyilnders.)

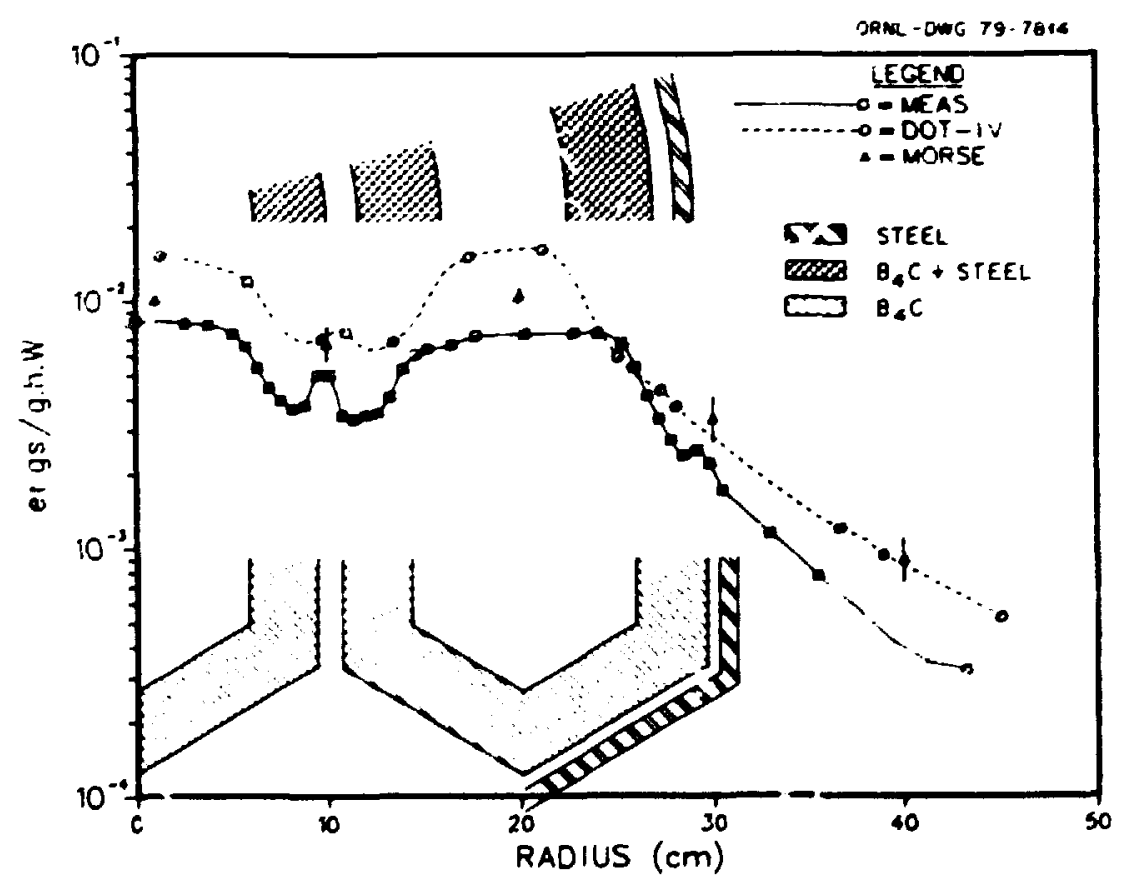

Fig. 7.14. Comparison of Calculated and Measured Hornyak Button Responses for a Fuia, :. verse $2.22 \mathrm{~cm}$ Behind GrId-Plate Shleld Conf Iguration II.D. 


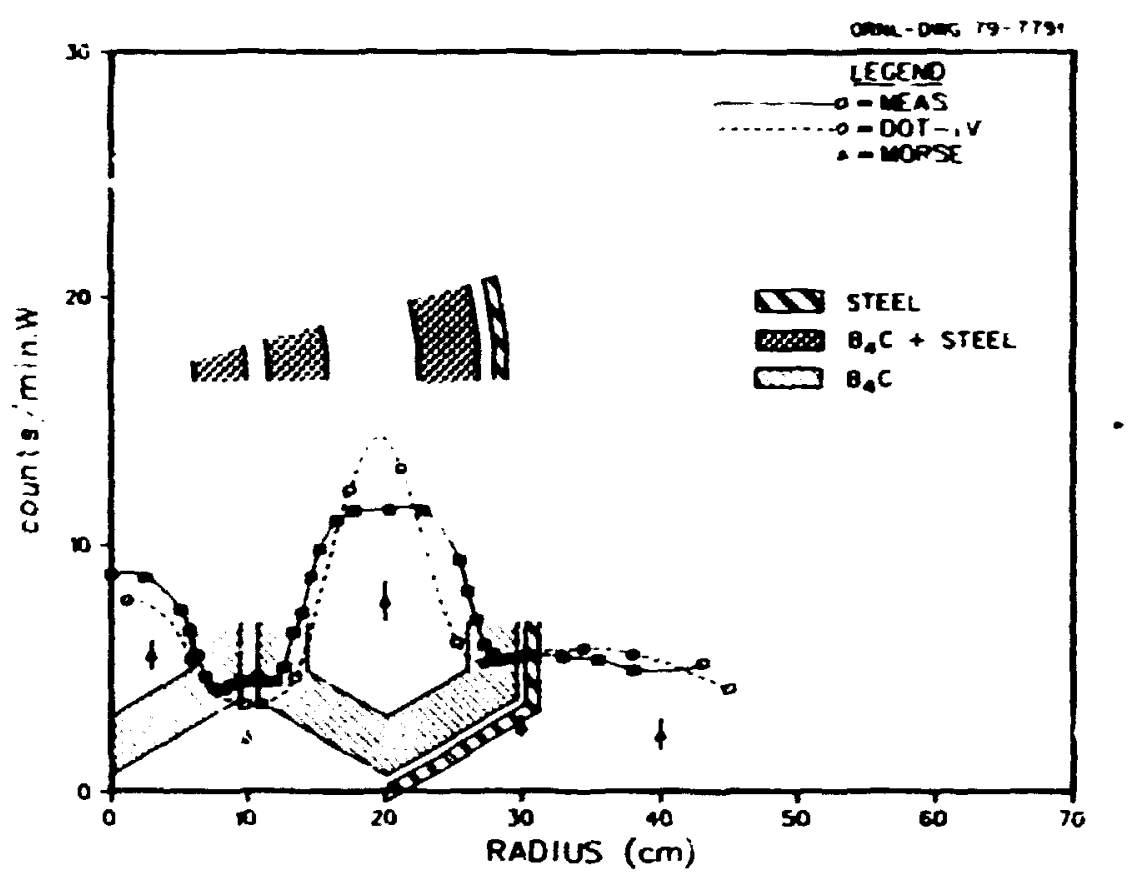

Fig. 7.15. Chaparison of Calculated and Measured 2-in. Cadalum-Coverer Monner Ball Count Rate for a Rajlat Traverse $3.18 \mathrm{~cm}$ Behind Grid-Plate Shield Cont Iguratiai II.D.

uninterrupted the full $360 \mathrm{deg}$, It was narrower than the actual vold in the subassamolles, and this is reflected in the narrower Idths of the calculated peak fluxes about the axis of the subassemblles.

As has been characteristic of the Hornyak tutton responses, ..e calculated responses shown in FIg. 7.14 for Contiguration 11.0 are higher than the measured responses because of the difficulty in normalizing the Hornyak button response. Aiso the peak depicting the flux at the location between subassemblles is much wore prominent in the masurements than in the DOT calculations. The measuremenis show a fast-neutron peak-to-minimum exposure ratio of 1.5 across the interassembly gap, whlle the DOT-calculated ratlo is 1.3. Thls is primarlly due to the DOT code overestimating the local minimum rather than underestlmating the local maximum.

The MORS calculation ylelded point values for Conflguration II.D that were in nearly complete egreement with the Dot-calculated Hornyak button responses (FIg. 7.14) but were conslderebly lower then the Dot-calcuiated 2-in. cadmlum-covered Bonner bali responses (FIg. 7.13). ThIs is due to MORSE having trouble generating low-energy fluxes. 
Plots of wasured end Dot-calculeted results for 2-in. cadiun-cevered Bonrer ball and Hornyak button radial traverses directly behind Configuration IV.B mere essentialiy identical in shape with those for Configuration 11.0, but were higher In magnitude. The peak 2-in. Bonner ball measurement between subassemblies, for exaple, was 6.2 counts/min-w for nor:iguratic: 1V.8. wherees, as show: in Fig. 7.15 . it was 4.5 counts/min-W for Confinuration 11.0. Sirilarly, the peak Hornyak button measurenent between subassemollies was $8.01 \times 10^{-3} \mathrm{ergs/g.h.in} \mathrm{for} \mathrm{Configuration} \mathrm{IV.B,} \mathrm{whereas,} \mathrm{as} \mathrm{shoun} \mathrm{in} \mathrm{Fig.} \mathrm{7.14,} \mathrm{it} \mathrm{was}$ $5.61 \times 10^{-3}$ ergs/g.t.w for Configuration 11.0. The difference tetween the two configurations is, of course, in the number of fuel pins per subassembly, Configuration IV.E having on!y 91 and Configuration 11.0 having 127. Corresponding peak Hornyak button measurements for Configurations 111.6 ard VI.B, each of which had 127 fuel pins per subassembly tut had gap widths of $0.635 \mathrm{~cm}$ ang $0.318 \mathrm{~cm}$ respectively, were $3.74 \times 10^{-3}$ ane $3.24 \times 10^{-3}$ ergs/g.n.W, indicating trat the peak fast-neutron flux emerging from the gap decreases with decreasing gap wicth.

The peak-to-ninimum fast-neutron exposure ratios across the interassently gap are somewhet smaller for Configuration IV.E than those for Configuration II.0. The neasurements give a ratic of 1.4 (comparec to 1.5 quoted above for 11.0$)$ and the calculations give a ratio of 1.2 (con sared to 1.3 quoted above for 11.0 ). Conflguratiuns 11.0 and IV.E both have interassembiy gaps of $1.27 \mathrm{~cm}$, the maximum gap tested. Hornyak button racial traverses directly behine the configuratlons with smaller interassembly yaps showed that the fast-neutron peak-to mirimum exposure ratio decreased with decreasing gap width, the ratlo being 1.3 for the $0.635-\mathrm{cm}$ gap (Configuration $111 . \mathrm{B}$ ) and 1.15 for tre $0.318-\mathrm{cm}$ gap (Configuration VI..2).

For the Hornyak button axial traverse in Configuration. 11.0 from the fuel section to beyond the configuration, the DOT-calculated responses vere again typlcally higher by a factor of 2 than the measurec responses. The Monte Carlo results agreed wth the DOT resulis doep within the shleld but approsched the measurements near the edge of the shield and beyond the configuration. For the 2-in. cadmium-covered Bonner ball axlal traverse, the DOT-calculated and measured responses vere essentlally in agreement over the full traverse. Again, the Monte Carlo calculatlons agreed with the DOT calculations (and with the measurements) out to the edge of the conflguretion, but beyond the edge the 
Monte Carlo values tell below the measured values. Mille the statistics of the Plonte Carlo calculation vere good. It is bell leved that in both cases the maRse resuits dropged off because nectrons folled to penetrete a sufficient distance into the shieli to provide adequate saupling of the scattering dIstribution near the end of the shleld. Thus tire responses vere consistently underpredicted.

Comparisons of the DOT (and DOT/DISKTRAN) calculatlons and the measurements at onaxis detector locations $30.5 \mathrm{~cm}$ and $305 \mathrm{~cm}$ beyond the configurations are shown in Tabie 7.5. As has come to be expected, the calculations overpredicted the Hornyet button responses by about a factor of 2 In all cases and they overpredicted the Bonner ball! responses for the 315-ca location. At the 30.5-callocation, the calculated and measured Bonner bal! response; are In good agreement. It is to be noted that the lower materlal density and increase: transmission in Configuration IV.B increases the Hornyak measurements (relative to Configuration II.D) by tactors of 1.9 and 1.6 at the $-30.5-\mathrm{cm}$ and $305-\mathrm{cm}$ locations respectively. Also, the $\mathrm{Cl}$ iser fuel subassembly spacing of Configuration VI.B apparentiy liad little effect on the measured responses (compare with Conf Iguration 111.8$)$.

Comparing the measured values for Conf Igurations V.B and IV.B shows that removing the seven central fuel pins from the central :ubassembly to simulate the control channel has an even greater effect on the fluxes emerging from the grld-plate shleld section than It did on the fluxes coming from the fuel-pin section. In this case, the fast-neutron fluxes (Hornyak button responses) for the conflguration with the control channel (Configuration V.B) were signiflcantly higher at both the $30.5-\mathrm{cm}$ location and the $305-\mathrm{cm}$ location, by $29 \%$ and 183 respectively. On the other hand, the peak fast-neutron exposure to the grid plate in Conflguration V.B $\left(7.59 \times 10^{-3}\right.$ ergs/g.h.W), as deduced from Hornyak button radial troverses Immedlately bohind the configuration, was actually 68 lower than the peak exposure to the grid plate in Configuration IY.B. The total fi.xes (5-In. Bonner ball count rates) were higher by 98 and 58 respectively.

Overall, the study of the grid-plate shleld conflgurations Indicete thet the neutron flux Impinging on the grid plai, can be calculated reasonably well with two-dimensional gecmetry, and whlle?. exignt of lacelized peaking was less pronounced in the calculations then in the mea;urements, the peak damage to the grid plate was calculated 
Table 7.5. Comparison of DOT-Calculated and Masured Detector Responses on Axis $30.5 \mathrm{~cm}$ and $305 \mathrm{~cm}$ Beyond Varlous Grid-Plate Shlels Contigurations

\begin{tabular}{|c|c|c|c|c|c|}
\hline \multirow[b]{2}{*}{ Detector } & \multicolumn{5}{|c|}{ Configuration } \\
\hline & $(1,27.127)=$ & $\begin{array}{c}111 .-8 \\
(0.633 .127) \\
\end{array}$ & $\begin{array}{l}\text { (1..8 } \\
(1.27,91)\end{array}$ & $(1.27,91 \div$ & $\begin{array}{c}11 . \theta \\
(0.318,027) \\
\end{array}$ \\
\hline \multicolumn{6}{|c|}{ Response at 30.5 o Beyund Conitiguration } \\
\hline \multicolumn{6}{|c|}{ Sonner tail , xats/ain w) } \\
\hline \multicolumn{6}{|c|}{ 2-in, C1-conerd : ball. } \\
\hline $\begin{array}{l}\text { Ca!culated } \\
\text { Measured } \\
\text { Calc./meas. }\end{array}$ & $\begin{array}{l}5.20+0^{7} \\
4.92+C \\
1.06\end{array}$ & $4.75 \div 0$ & $\begin{array}{l}9.37+0 \\
9.91+0 \\
0.55\end{array}$ & $1.23+1$ & $4.66+0$ \\
\hline \multicolumn{6}{|l|}{ 5-in. ball } \\
\hline $\begin{array}{l}\text { Colculeted } \\
\text { Mesured } \\
\text { Calc./meas. }\end{array}$ & $\begin{array}{l}1.92+3 \\
9.76+2 \\
1.15\end{array}$ & $8.88+2$ & $\begin{array}{l}1.23+3 \\
1.52+3 \\
1 .: 2\end{array}$ & $1.65+3$ & $8.58+2$ \\
\hline \multicolumn{6}{|c|}{ Hornyak button (ergs/g-h.w) } \\
\hline $\begin{array}{l}\text { Calculated } \\
\text { Measured } \\
\text { Calc./Meos. }\end{array}$ & $\begin{array}{l}5.94-3 \\
2.91-3 \\
2.04\end{array}$ & $2.24-3$ & $\begin{array}{l}1.08-2 \\
5.40-3 \\
2.00\end{array}$ & $6.95-3$ & $2.26-3$ \\
\hline
\end{tabular}

Bonner ball (counts/min-w)

2-ir.. Cd-covered ball

\begin{tabular}{|c|c|c|c|c|c|}
\hline $\begin{array}{l}\text { Calculated } \\
\text { Mossured } \\
\text { Calc./Meas. }\end{array}$ & $\begin{array}{l}1.66+0 \\
1.22+0 \\
1.36\end{array}$ & $9.36-1$ & $\begin{array}{l}2.70+0 \\
2.14+0 \\
1.26\end{array}$ & $2.30-0$ & $8.20-1$ \\
\hline
\end{tabular}

$5-\ln$. ball

\begin{tabular}{|c|c|c|c|c|}
\hline $\begin{array}{l}\text { Calculated } \\
\text { Measured } \\
\text { Calc./Meas. }\end{array}$ & $\begin{array}{l}1.87 \cdot 2 \\
1.18+2 \\
1.58\end{array}$ & $9.51+1$ & $\begin{array}{l}2.65+2 \\
1.77+2 \\
1.50\end{array}$ & $1.86+2$ \\
\hline
\end{tabular}

Hornyak button (ergs/g.h-w)

\begin{tabular}{|c|c|c|c|c|c|}
\hline $\begin{array}{l}\text { Calculated } \\
\text { Measured } \\
\text { Cal:-_/Mas. }\end{array}$ & $\begin{array}{l}1.25-3 \\
5.94-4 \\
2.10\end{array}$ & $4.32-4$ & $\begin{array}{l}1.99-3 \\
9.58-4 \\
2.08\end{array}$ & $1.21-3$ & $4.17-4$ \\
\hline
\end{tabular}

$-(1.27,127)$ Indlcates $1.27 \mathrm{~cm}$ between fuel subassemblles, 127 fuel pln3 per subassembly.

tonly ar fuel pins in central subassembly.

$\$_{\text {Read: }} \quad 3.20 \times 10^{0}$. 
with good precision. At large distances, however, the Dor-calculated results are persistentiy higher than the measured results. As was the case fo the funi-pin corfigurations, the overprediction is belleved to be attributable to the fact that the spatial mest. used In the calculations was too coarse.

\subsubsection{Transport Calculations for Prototypic Grictiate Configuration}

The full grit-plate configurat!on, wich included the fuel-blanket section, the gricplate shield section, and the gricplate section, was Identitied as Configuration II.F and is tha configuration depicted in Fig. 7.1. The fuel section of this contiguration consisted of the seven subassemblies that contained 127 fuel pins each and were spaced $1.27 \mathrm{~cm}$ apart (see Section 7.4.3), and the grid-plate shield section conslsted of the seven $e_{4} C-f i l l e d$ subassemblies et the sene spacing. Details of the grid-plate section are shown in Fig. 7.16. As noted ear!ier. the 63.5-an thickness selected for the grid plate included an extra 2.50 of irce for reasors noted in Section 7.2. The $B_{4} C$ inserts shown in Figs. 7.1 and $7 . i 6$ represent extensions of the shield subassentilies into the grio plate.

The measurements for the full gric-plate conf guration deplcted in Fig. 7.1 included a Hornyak button radial traverse directiy behind the grid-plate conflguration. $r$ a distance of $2.62 \mathrm{~cm}$ ) and $N E-213$ and hydrogen counter spectral measurements as close betind the conflguration as was feas:tle $(a+34.3 \mathrm{~cm})$. In adeition, radial traverses were made with the Hornyar button and the 2-in. cadmium-covered and 5-in. Bonner balli at distances of $305 \mathrm{~cm}$ and $30.5 \mathrm{~cm}$. Finally, nn-axis measurements vere made at the 305-cm lcoation with the 3-, 6-, 8-, and 10-in. Bonner hal is and at th, 34.3-cm locatlon with the 3-in. Eomner tall. At some of these locations, additional measurements were made - ith the $\mathrm{B}_{4} \mathrm{C}$ inserts removes.

The DOT calculations of the full grle-plate contlguration were parformed with the 5l-group $P_{3}$ cross secilions and the 150-direction blased quadrature set used in the earlier calculations; however, in tris caso th -ulational mosel included the entire preceding ection of the conflguretion (that is, the grid-plate shleld section) and the internal boundary source (output frcm the calculation for Cantiguration 11.0 ) was located 


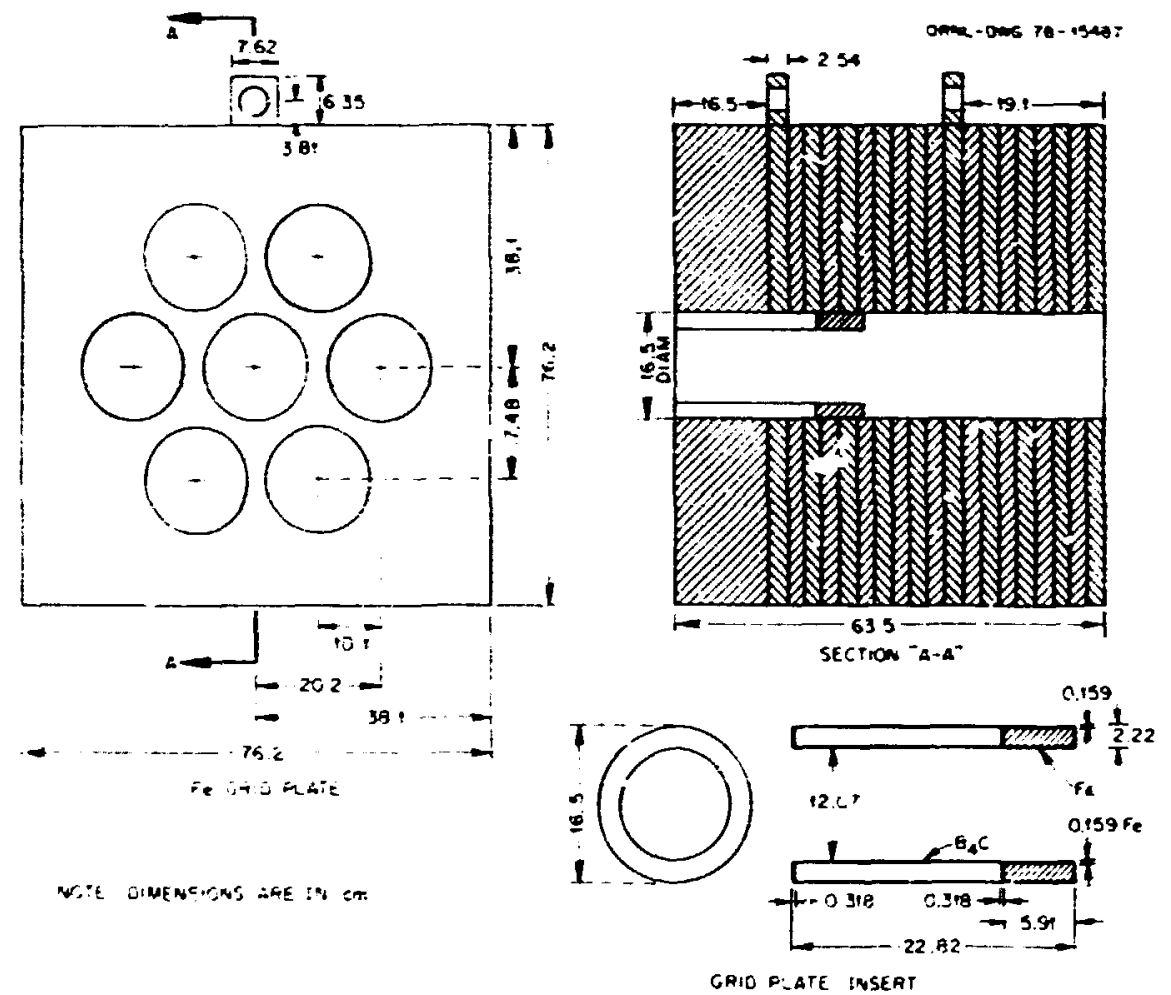

Fig. 7:16. Detilis of the Prototyplc Grid Plate and Cylindrical Grid-Plate Shield Inserts.

$2.54 \mathrm{~cm}$ from the end of the fuel section. Like the shield region, the grid-plate reglon was converted to equivalent cylindrical annull, with the vold reglons matching in the two sections.

The MORSE calculations again used a 1/12th segment of the gecmetry and the same boundary source e: the Dor calculations.

The measured and calculated Hornyak button responses alcng a radial traverse diractly behind Configuration II.F are shown in Flg. 7.17, where again the lower sketch depicts the actual gecmetry of the grid plate (the central hole and one of the six surroundiri; outer holesl and the unper sketch shows the gecmetry used in the calculational model.

From FIg. 7.17 it is seen that the DOT calculations overpredicted the Hornyok button moasurements by a factor of about 3 and the MDRSE celculations overpredicted the meosurements by factors of 1.7 to 2 ; however, the shapes of both calculated curves are Ir. 


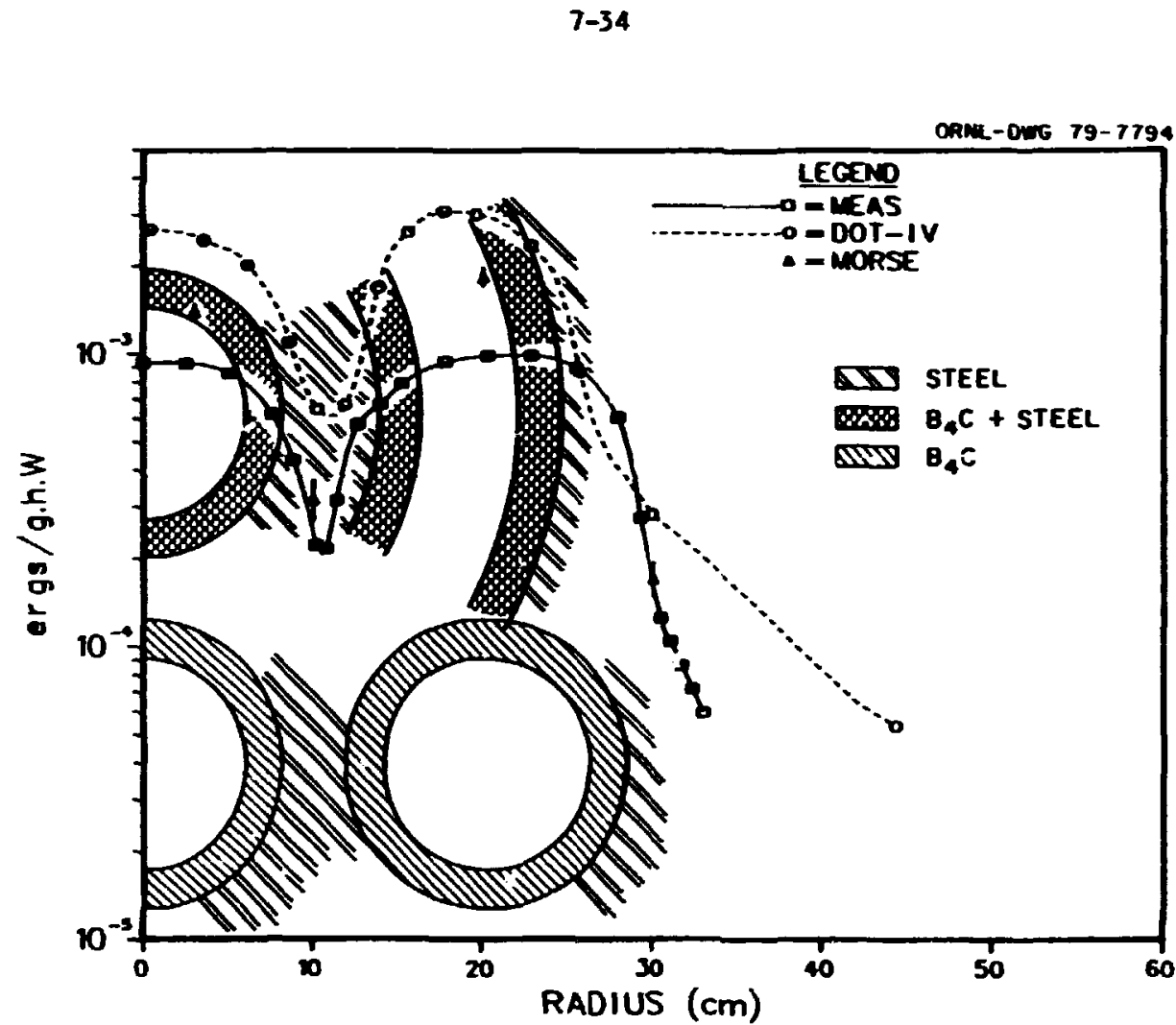

FIg. 7.17. ComparIson of Calculated and Heasured Hornyak Button Responses filong a Radial Traverse $2.52 \mathrm{~cm}$ Behind Grid-Plate Shleld Configuration II.F (with $\mathrm{B}_{4} \mathrm{C}$. Inserts).

good agreement with the shape of the measured curve. The measurements Ind lcate that the peak fast-neutron exposures to components In I Ine with the Inner and outer grld-plate holes would be $9.34 \times 10^{-4}$ and $1.01 \times 10^{-3}$ ergsig.h.W respectlvely, the measured value dIPpIng to $2.19 \times 10^{-4}$ ergs/g.h.W behind the steel between the volds and plunging rapisly as the radial distance from the outer vold Increases. WIthout the $\mathrm{B}_{4} \mathrm{C}$ Inser:5, the measurements are somewhat hlgher (see Table 7.6).

At distances of 30.5 and 305 an beyond the conflguration, DOT and MORSE also overpredicted the Hornyak button responses along radial traverses, DOT by factors of 3 and 2.7 respectively and mORSE by factors of 1.5 to 2 and 1.7 respectively. The measured peak exposures at these distances are Included In Table 7.6.

As has been noted In earller sections, the general pattern of the calculatlons overpredicting the Hornyak button responses throughout the grid-plate shield study appear to be due to the difflculty encountered in normalizing the Hornyak button response 
Table 7.6. Peak Fast-Neutron Exposures (Hornyak Button Responses) Beyond Grid-Plate Conf Iguration II.F

\begin{tabular}{|c|c|c|c|c|}
\hline \multirow{3}{*}{$\begin{array}{l}\text { Distance Beyond } \\
\text { Configuration }(\mathrm{cm})\end{array}$} & \multicolumn{2}{|c|}{$\begin{array}{l}\text { Peak Measured Response } \\
\text { (ergs/g-h-(U) }\end{array}$} & & \\
\hline & \multirow{2}{*}{$\begin{array}{c}\text { Opposite } \\
\text { Inner } \\
\text { Vold }\end{array}$} & \multirow{2}{*}{$\begin{array}{l}\text { Opposite } \\
\text { Outer } \\
\text { Void }\end{array}$} & \multicolumn{2}{|c|}{ Calc./Meas. } \\
\hline & & & DOT & MORSE \\
\hline 2.62 (with $\mathrm{B}_{4} \mathrm{C}$ Inserts) & $9.34-4$ & $1.01-3$ & 03 & $1.7-2$ \\
\hline $2.62\left(w / 0 B_{4} C\right.$ Inserts $)$ & $1.07-3$ & $1.14-3$ & & \\
\hline 30.5 (with $\mathrm{B}_{4} \mathrm{C}$ Inserts) & $5.96-4$ & $6.67-4$ & 63 & $1.5-2$ \\
\hline 30.5 (w/o $B_{4} C$ inserts) & $6.51-4$ & $7.31-4$ & & \\
\hline 305 (with $B_{4} C$ Inserts) & $2.78-4$ & $2.50-4$ & 22.7 & $\sim 1.7$ \\
\hline
\end{tabular}

function. But even with the normalization factor taken into account, the Dot results stlll appear to be high. For example, if it could be assumed that the MORSE curve shown In FIg. 7.17 were correct except for the normalizatlon factor, and thus that the MORSE curve could be normal ized to the measurements and the DOT curve lowered accordingly, the DOT curve would stlll be high by a factor of 1.5 to 1.75 .

In the case of the 2-In. cadmlum-coveref Bonner ball, the Dot results are In good agrement with the measured results for the radlal traverse at $30.5 \mathrm{~cm}$, whlle the MORSE results sre low except for the polnt drectiy In IIne with the outer grid-plate hole, where both calculated values and the measured value are all close. At $305 \mathrm{~cm}$ the MORSEcalculated polnts lle on the measured curve, while the DOT-calculated curve is higher than the measured curve by a factor of 2 behind the grid-plate holes. At larger radlal distances, the DOT results are in somewhat better agreement with the measured values.

For the 5-in. Bonner ball, the DOT results for the 30.5-cm radial traverse are higher than the masured results by a foctor of 1.25 behind the central hole ond by a factor of 1.55 behind the outer hole. Again the MORSE results for the 30.5-cm traverse are too low except for the one polnt in IIne with the outer grid-plate hole, where the MORSE and measured polnts are In egrecinent. 
At $305 \mathrm{~cm}$ the DOT results for the 5 -in. Bonner ball reanaln a factor of 2 higher than the measured results behind the grid-plate holes with somewhat better agreenent at radial dIstances beyond the holes (see FIg. 7.18). As was the case for the 2-In. Bonner ball at this distance, the mORSE-calculated polnts for the 5-in. ball essentialiy lie on the measured curve, this time with such good statistics that the error bars were smaller than the plotting symbols and thus could not be shown.

The curves for the radial traverse measurements at $305 \mathrm{c}$ are simllar in shape for all three detectors in that twere is a relatively flat region behind the grld-plate hoies, a rapld dropoff from 30 to $80 \mathrm{~cm}$, and a flattenling beyond $80 \mathrm{~cm}$. The curves for the DOT calculations have a slallar shape except that the flattening begins beyond 100 $\cos$.

The neutron spectral measurements made on the axis at a distance of $34.29 \mathrm{~cm}$ beyond the grid plate are compared with DOT-calculated and MORSE-calculated spectra in Figs. 7.19 and 7.20 respectively. While the the DOT-calculated spectrum and the measured spectrum are very simllar In shape, the calculated Integral flux is about 50 s higher than the measured Integral flux. Conversely, the MRSE-calculated spectruen and the measured spectrum do not agree too well In shape; however, above 0.9 MeV the Integrated 4 I uxes are relatively close, the MORSE-calculated flux being $0.89 \pm 0.13$ of the measured flux.

On-axls measurements at the $34.29-\mathrm{cm}$ locatlon were also made with the $3-\mathrm{In}$. Bonner ball, and at the 305-cm location with several Bonner balls. These results are compared with the corresponding DOT- and MORSE-colculated values In Table 7.7. It Is noted that the DOT-calculated count rate for the 3-In. Bonne- ball ot $34.29 \mathrm{~cm}$ is $\mathrm{hlgher}$ then the measured count rate by a factor of 1.4 , and, as polnted out above, the DOT-calculated fast-neutron flux at this location is igh by about a factor of 1.5, whlle the MORSEcalculated fast-neutron flux is low.

At the 305-cm locotion, al the DOT-calculated Bonner ball count rates (cover Ing most of the neutron spectrum) are about a factor of 2 higher than the measured count rates. These results Indlcate that the angular flux collimated through the gr id plate may be overpredicted by a factor of 2 since It would be the collimated component thet would make the largest contribution of large distances behind the grid plate. As hes 


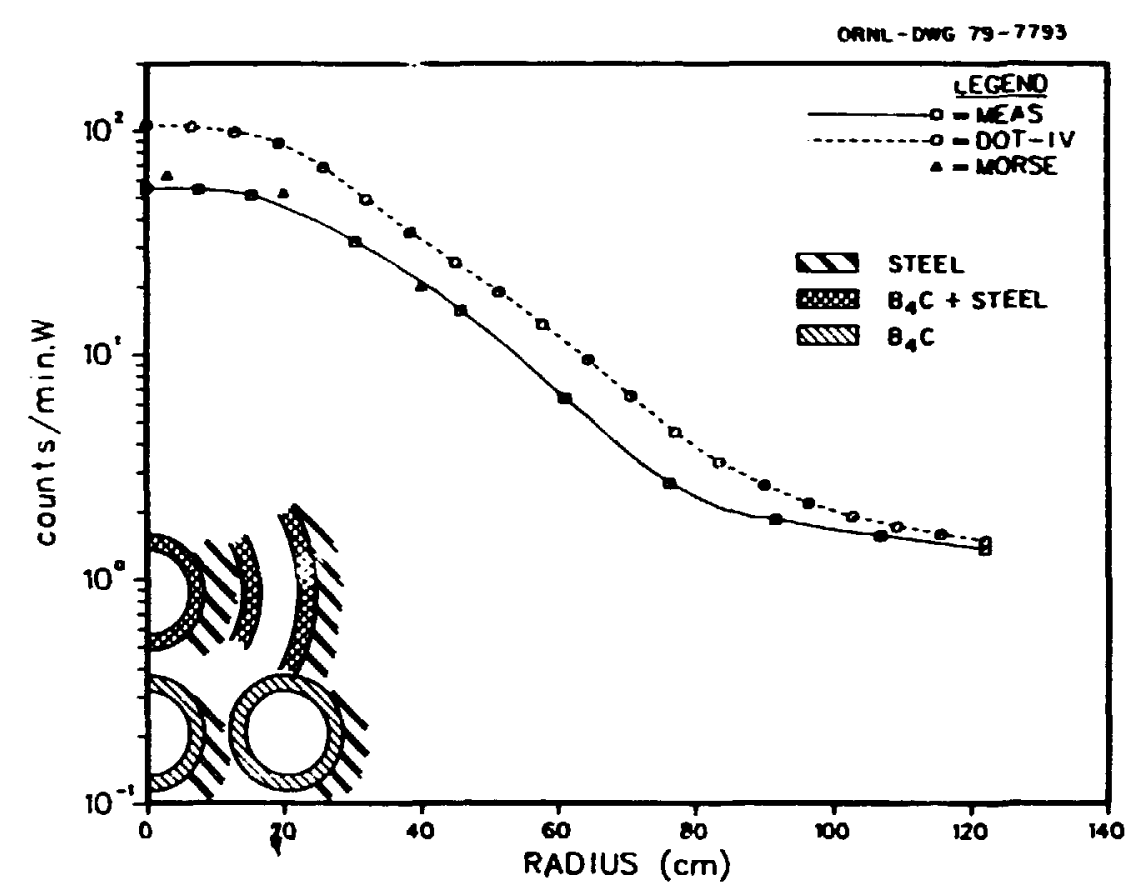

Fig. 7.18. Comparison of Calculated and Measured 5-in. Bonner Ba'l Count Rates Along a Radial Traverse $305 \mathrm{~cm}$ Behind Grid-Plate Conf Iguration II.F.

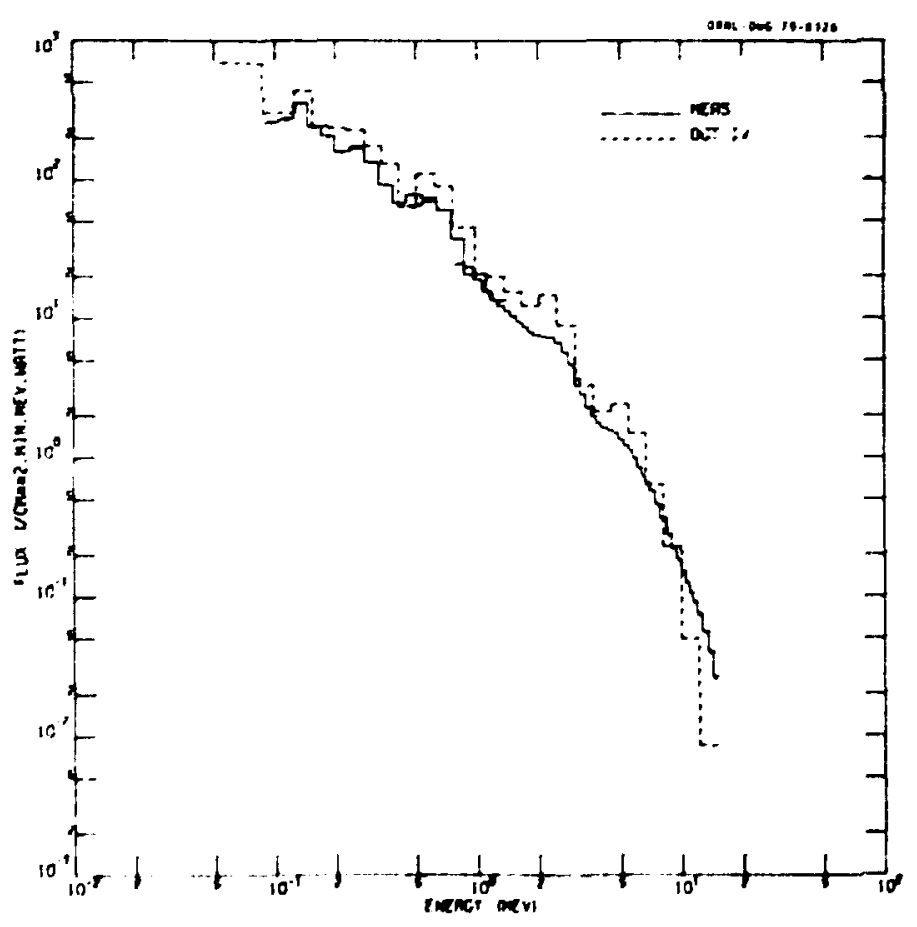

Fig. 7.19. Comperison of DOT-Calculoted and Measured Neutron Spectra $34.3 \mathrm{~cm}$ Beyond Grid-Plate Cont Iguration II.F. 


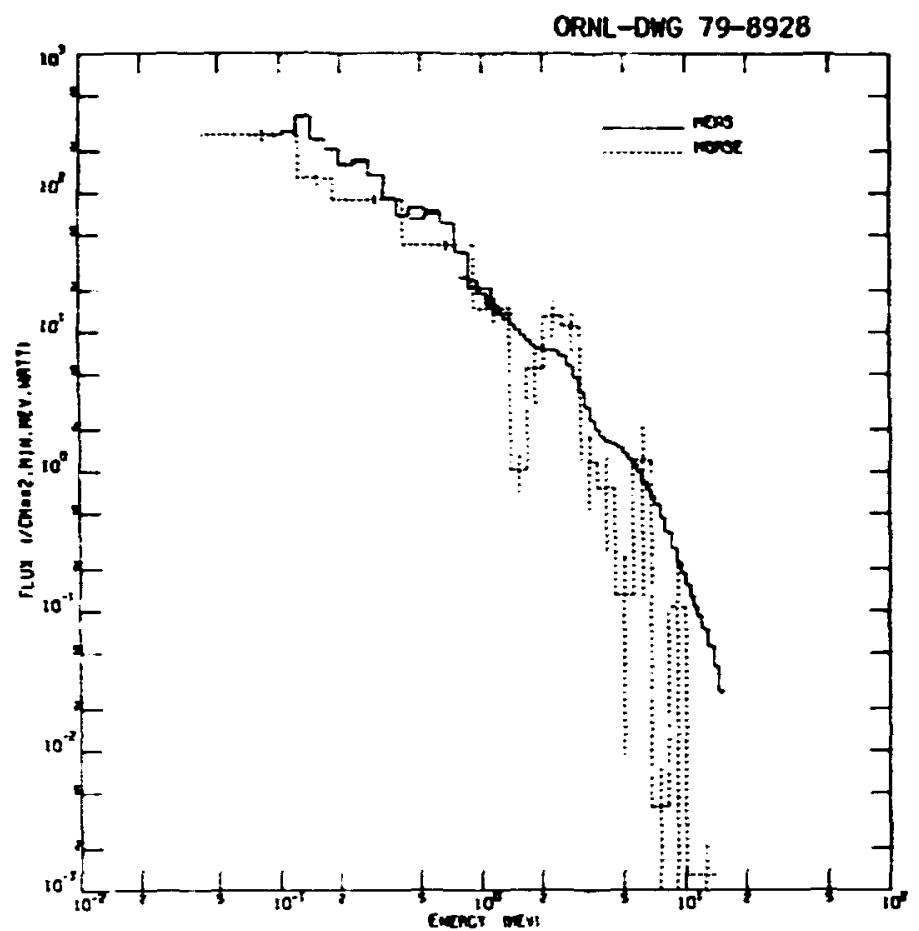

FIg. 7.20. Comparison of MORSE-Calculated and Maasured Neutron Spectra $34.3 \mathrm{~cm}$ Beyond Grid-Plate Configuration II.F.

Table 7.7. Comparison of Calculated and Measured Detector Responses on Axis 34.29 and 305 an Beyond Gr!d-Plate Conflguration II.F

\begin{tabular}{|c|c|c|c|c|c|}
\hline \multirow[b]{2}{*}{ Type of Response } & \multirow{2}{*}{$\begin{array}{l}\text { Measured } \\
\text { Response }\end{array}$} & \multicolumn{2}{|c|}{ Calculated Response } & \multicolumn{2}{|c|}{ Calc./Meas. } \\
\hline & & DOT & MORSE & DOT & MORSE \\
\hline \multicolumn{6}{|c|}{ Response at $34.3 \mathrm{~cm}$ Beyond Conf Iguration } \\
\hline \multicolumn{6}{|l|}{$\begin{array}{l}\text { Integrated spectrometer fluxes } \\
\left.\text { (neutrons } / \mathrm{cm}^{2} \cdot \mathrm{mln} \cdot \mathrm{l}\right)\end{array}$} \\
\hline $\begin{array}{l}E>0.9 \mathrm{MaV} \\
E>0.12 \mathrm{MeV}\end{array}$ & $\begin{array}{l}26.61 \\
99.22\end{array}$ & $\begin{array}{c}40.99 \\
146.4\end{array}$ & $\begin{array}{r}23.62 \pm 3.42 \\
72.0 \pm 4.38\end{array}$ & $\begin{array}{l}1.54 \\
1.48\end{array}$ & $\begin{array}{l}0.89 \pm 0.13 \\
0.73 \pm 0.04\end{array}$ \\
\hline \multicolumn{6}{|l|}{ Bonner ball (counts/min.w) } \\
\hline $3-\ln$. ball & 42.6 & 59.0 & - & 1.4 & - \\
\hline \multicolumn{6}{|c|}{ Response of $305 \mathrm{~cm}$ Beyond Conf Iguration } \\
\hline \multicolumn{6}{|l|}{ Bonner ball (counts/min.w) } \\
\hline $\begin{array}{l}2-1 n \text {. ball (Cd-covered) } \\
3-1 n \text {. boll } \\
5-1 n \text {. ball } \\
6-1 n \text {. boll } \\
8-1 n \text {. boll } \\
10-1 n \text {. boll } \\
12-\ln \text {. boll }\end{array}$ & $\begin{array}{l}0.493 \\
12.3 \\
55.1 \\
62.1 \\
50.8 \\
29.6 \\
16.8\end{array}$ & $\begin{array}{l}1.08 \\
25.6 \\
116 \\
127 \\
101 \\
62.6 \\
36.4\end{array}$ & $\begin{array}{c}0.462+0.074 \\
=- \\
62.6 \pm 6.89 \\
= \\
=\end{array}$ & $\begin{array}{l}2.1 \\
2.1 \\
2.1 \\
2.0 \\
2.0 \\
2.1 \\
2.2\end{array}$ & $\begin{array}{c}0.94 \pm 0.15 \\
\bar{z} \\
1.14 \pm 0.12 \\
= \\
=\end{array}$ \\
\hline
\end{tabular}


been polnted out in earller sections, these overpred' rlons at large distanres are thought, at least in part, to be due to the use.., an Inadequate spatial mesh in the calculations.

\subsection{SUMARY}

then the TSF-GCFR grid-plate shield confirmation experiment was begun, une of the major concerns was whether the streasing of neutrons through a fuel lattice simulating a section of the GCFR core could be accurately presicted and, further, whether changes in the spacing between fuel subassemblles and/or fuel pins wouid arkedly affect the neutron transmission from the core through the grid plate. Another major concern, of course, was whether the GCFR grid plate, and also components "abovew" the grid plate, could be adequately shlelded from radiation damage without overiy restricting the react $r$ coolant flow. In an attempt to answer these questions, the experiment was designed so that neutrons from the Tower Shlelding Reactor II would Induce fissions in a fuel lattice mocking up seven GCFR-type fuel-pin assemblies and the lattice rould be the dominant source in the experiment. The experimental procedure then called for detalled measurements (and calculations) to be made for varlous sections of the configuration as they were added behind the fuel latrice. Not oniy did this allow the adequacy of the avallable calculational methods to be tested for successive regions, :t also made it possible to measure (and calculate) the effect of varlations within the Individual regions.

As has been described in earller sectlons, the measurements were performed with a combination of detectors. A Hornyak bution responded primarlly to fast neutrons, 3 2-ir. cadmlum-covered Bonner ball to low-energy neutrons, and a 5-in. Bonner ball to the total flux. Neutron spectra were obtalned with an NE-213 spectrometer that covered neutron energles from 0.8 to $15 \mathrm{MeV}$ and a hydrogen counter that covered energles from 0.08 to 1.5 MeV. In addition, measurements with a serles o' Bonner balls of different diameters essentlally covered the full spectrum.

When this study was performed the GCFR design speclfled a top-mounted grid plate, above $\because$ ich control-rod mechan isms were to operate in "il uppe. plenum. Subsequently, the design was revised to have a bottom-mounter gi id plate. 
Most of the calculations were performed with the DOT discrete ordinates code using two-cimensional gecmetric models simulating the exper imental configuration. In order to Include streaning paths, a heteroganeous model wos employed which consisted of concentric annull representling low-oensity and high-denslty reglons as required to simulate the region being calculated. Check polnts were calculated with the morse Monte Carlo code us Ing "exact" three-dimensional models.

The experimental and calculational results ore sumarlzed below.

\subsubsection{Fuel-PIn ConfIgurations}

In Invest Igating the neutron streaing In GCFR-type fuel Iaftices, It was Important to Include variations In the spacing between fuel subassemblles that would bracket those being considered for the GCFR and also to Inciude a rangs of fual dorisities within the subassemblles. Thus, the experinent covered fuel subessembly specings from $0.318 \mathrm{~cm}$ to $1.27 \mathrm{~cm}$ and Included two types of subasseablies, one containing 127 fuel pins and anuther contalnirg 91 fuel plns. The calculated-to-masured ratlos for lccations beyoud fuel-pin configurations with varlous combinations of these variables are summarized In Tables 7.8 and 7.9 .

The results presented In Table 7.8 show that for the Bonner bal is and the neutron spectramoters the calculations and mesurements are in good agrecment over a distance extending to $140 \mathrm{~cm}$ beyond the conf Igur atlons. At a distence of $305 \mathrm{cr}$, hovever, the calculations consistently overpredict the Bonner ball responses, end at all locatlons the calculations overpredict the Hornyak button responses. On the basls of these anc slallar Hornyek button results for subsequent conflguratlons. It wes concluded that the difflculty with calculoting the Hornyek button response was a norwalizetion problem with the detector's response function. And from a serles of additional calculetions for Configuration II.B It wes concluded that the other DOT-ialculated responses for the 305 location weuld approech the masured responses 11 a mor detolled spatlal mesh were used In the calculation. Thun, it eppers that the transission through the GCFR core can be calculated. 
Table 7.8. Sumary of Calculated-to-masured Detucter Responses Borond Vorlous Fuel-PIr ConfIgurations

\begin{tabular}{|c|c|c|c|c|}
\hline \multirow[b]{2}{*}{ Type of Response } & \multicolumn{4}{|c|}{ Cals., Oneos. } \\
\hline & $\begin{array}{c}11.8 \\
(1.27 .127)=\end{array}$ & $\begin{array}{c}111 . A \\
(0.635,127)\end{array}$ & $\begin{array}{l}\text { IV.A } \\
(1.27, g 1)\end{array}$ & $\begin{array}{l}11 \cdot A \\
(0.318,: 27 j\end{array}$ \\
\hline \multicolumn{5}{|c|}{$30.5 \mathrm{cc}$ Beypond Conf iguration } \\
\hline \multicolumn{5}{|l|}{ 2-In. Cd-covered Eonner ball } \\
\hline $\begin{array}{l}\text { DOT/moes. } \\
\text { MDise/liness. }\end{array}$ & $\begin{array}{r}0.94 \\
1.05\end{array}$ & 0.98 & 0.82 & 9.97 \\
\hline 5-In. Bonner ball & & & & \\
\hline $\begin{array}{l}\text { DoTrumas. } \\
\text { moise/lias. }\end{array}$ & $\begin{array}{c}1.0 \\
21.04\end{array}$ & 1.05 & 0.94 & 1.03 \\
\hline \multicolumn{5}{|l|}{ Hornyek button } \\
\hline $\begin{array}{l}\text { Dot/liaes. } \\
\text { monse/maes. }\end{array}$ & 2.4 & 1.61 & 1.35 & 1.76 \\
\hline \multicolumn{5}{|c|}{ 138.1 ca Berond ConfIgaration } \\
\hline 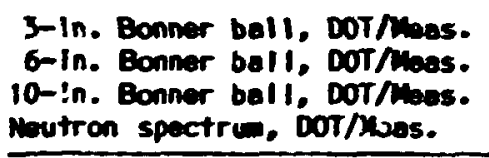 & $\begin{array}{l}1.21 \\
: .16 \\
1.08 \\
\text { Agreamen }\end{array}$ & In shepe anj & egnitude for & 11.9 \\
\hline \multicolumn{5}{|c|}{305 on Beyond Corfiguration } \\
\hline \multicolumn{5}{|l|}{ 2-In. Cd-covered Bonner bell } \\
\hline $\begin{array}{l}\text { DOT/Mmas. } \\
\text { miss/Minas. }\end{array}$ & $\begin{array}{l}1.46 \\
1.22\end{array}$ & 1.95 & 1.22 & 1.79 \\
\hline \multicolumn{5}{|l|}{ 5-in. Bonner ball } \\
\hline $\begin{array}{l}\text { DOT/lmas. } \\
\text { DOT/Mas.' } \\
\text { moRse/loas. }\end{array}$ & $\begin{array}{l}1.34 \\
1.11 \\
1.21\end{array}$ & 1.57 & 1.26 & 1.62 \\
\hline \multicolumn{5}{|l|}{ Hornyak buttan } \\
\hline $\begin{array}{l}\text { Dor/lioes. } \\
\text { ionse/Minas. }\end{array}$ & $\begin{array}{l}1.71 \\
1.27\end{array}$ & 2.19 & 1.71 & 2.29 \\
\hline
\end{tabular}

$-(1.27,127)$ indlcotas 1.27 a batwen ful subessamblies, 127 fuol plins par subessembiy.

toor celculotion repoeted with finer spotial wach (ses section 7.4.3). 
Tob 10 7.9. Sumary of Calculated and Mosured Effects of Changes In Fuel Subassabbly Spacing and In Fwal Density (Fueltin Conflguratlons)

\begin{tabular}{|c|c|c|c|c|}
\hline $\begin{array}{l}\text { Type of } \\
\text { Response }\end{array}$ & $\begin{array}{l}\text { Distance (on } N(\mathrm{~s}) \\
\text { Bupond Conf Igurat Ion } \\
\text { (a) }\end{array}$ & $\begin{array}{l}\text { Subassembly } \\
\text { Specling Effect. } \\
\text { II.BN/.A } \\
(1.27 / 0.318)^{\circ}\end{array}$ & $\begin{array}{l}\text { Fuel } \\
\text { Dansity Effect. } \\
\text { IV.NII:-8 } \\
\text { (91/127) }\end{array}$ & $\begin{array}{l}\text { Control } \\
\text { Chennal Effect, } \\
\text { V.Niv. } \\
\text { (w/nos) }\end{array}$ \\
\hline $\begin{array}{l}\text { 5-in. Bonner bail } \\
\text { Calc. }\end{array}$ & 305 & $\begin{array}{l}1.05 \\
0.95\end{array}$ & $\begin{array}{l}1.38 \\
1.44\end{array}$ & \\
\hline Maes. & $\underset{305}{30.5}$ & $\begin{array}{l}1.08 \\
1.16\end{array}$ & $\begin{array}{l}1.47 \\
1.5\end{array}$ & $\begin{array}{l}1.03 \\
1.04\end{array}$ \\
\hline $\begin{array}{l}\text { Horayek button } \\
\text { Calc. }\end{array}$ & $\begin{array}{l}30.5 \\
305\end{array}$ & $\begin{array}{l}1.05 \\
0.95\end{array}$ & $\begin{array}{l}1.53 \\
1.6\end{array}$ & \\
\hline moes. & $\underset{305}{30.5}$ & $\begin{array}{l}1.28 \\
1.24\end{array}$ & $\begin{array}{l}1.59 \\
1.64\end{array}$ & $\begin{array}{l}0.89 \\
1.01\end{array}$ \\
\hline
\end{tabular}

Ratio of response for conflguration 11.8 wth a $1.27-c$ specing between fuel subassemblies to response for conf Igur ation VI.A vith o 0.316-co specing betwean subassensl les.

b91 fuel plas in subassembly versus 127 fual plins in subassembly.

Cconflguration with control channal in central subesambly versus conf Iguration without control channel.

With respect to verietions vithin the fual Iattlce, both the calculated end the neasured $5-1 n$. Bonner ball responses in Teble 7.9 Indlcate only a saall of fect on the noutron streaing from the fuel lattice when the spocing botween fuel subessamblles is Increased from $0.316 \mathrm{~cm}$ to $1.27 \mathrm{~cm}$. The anasured responses reflect the lerger Impect, but conly en 85 increase of $30.5 \mathrm{~cm}$ and 165 increase of $305 \mathrm{~cm}$. The Hornyek button responses, however, show en increase in the fost-neutron flux of 204 of a d stence of $30.5 \mathrm{~cm}$ and 245 of a distance of $305 \mathrm{~cm}$. Thus, varyleng the gap slze probebly would not heve a Iarge overoll effect on the noutron leakege from the GCFR axlal blanket but It could affect the fraction of the lekkes complead of fast neutrons.

The fuol-pin specing (1.e., fuol donslty) eppers to heve e graster noutron trenciniesion offect then the sui ssembly specing. as is Indleoted by the IV,A/II,B retlos. At loth axlel locotlons the Bonmer ball responses (both calculeted and wessurec)

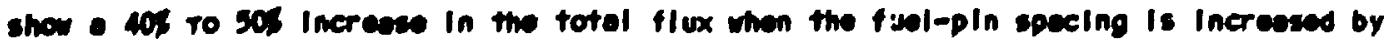
reducling the number of plas with in the evven esecmblles from 127 to 91 . The Hornyck button rasponsex Indicore slightly I rear Inercoses In the fastenoutron fluses - cbout cos on both lecertions. 
Comparing Configurations IV.A and II.B with each other. however, does not real IY shor how wach the strecing in the Individual Iattices is cahenced by the presence of the Iow-density (hallim) passegeweys. This vas investigated by performing edditional Dot

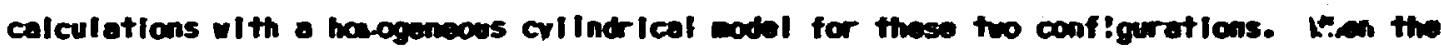
results ware comared with the corresponding velues cbtalined with the keterognocus nodal (I.e.. with the cylindrlcal-annull codel used for thic study), the strening offect for a

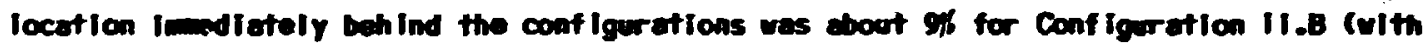
127 plins per subessembly) ad abot 118 for Configuration IV.A (rith 91 plrs per subassembly). Thus the stracing in both conf Igarefions wes entenced opproximatoly IOS by the halite pessegurars.

Underpredicticns of caly 10 in the noutr a streening offect would not be serloas in GCFR-type calculations and use of a homogneous codel to simplify des ign calculations wild be oftrective. However, for distances bevond the exporimental conf igurations the hamgenecus and heterogenecus celculations geve widaly divergent results. The Mmogneous calculations underpredleted the Bonnor ball count rates of a distence of 305 ca by 208 to 205 for Configuration II.e and by about R's for Conflguration IV.A, whereas the heterogeneous calculations overpredicted the sam count ratus by 351 to 50, for Conflgurotica II.B and about 25; for Conflguration IV.A. Thus for conservetIan, and especialiy wea the neutron penotretion thrsugh subsequent reglons is to be calculoted, the heterogeneous codel should be retalnes.

Finally, the mosured results In Table 7.9 (no calculations performad for Conflguration V.Al Indicate that reworing sowen fuel pins from the central fuel subassabbly had Ifirle effect on elther the total flux or the fest-nautron flux ist elther axlal locetion.

\section{5,2. Grid-piate Shield Configurations}

Studies of the grideplate shield conf Jgurations focusend on two qu vitionss cauld the region of the orid plete thet rould recelve the peck exposure to fest newtrons bo

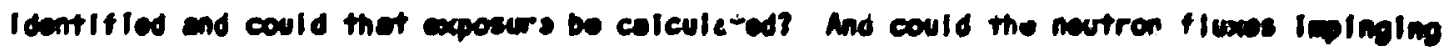
on the prideplate region be ecerstely predicted? 


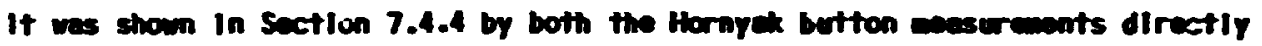
bahind the grid-plete shield and the correspondilg calculations that the pack festneutron exposure to the grld plete woald ocex on the botton of the grid plaie of

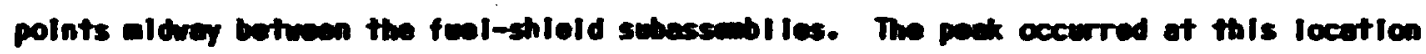

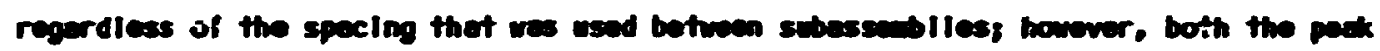

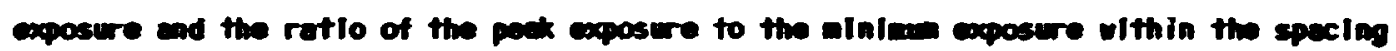
gep verled with the specleg end with the forl consity within the subessublies. Teble

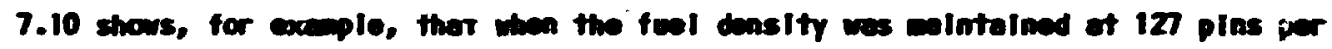

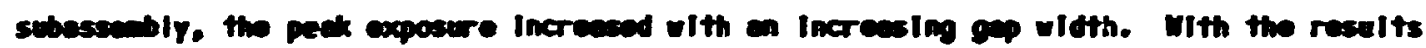
fra Conflguration VI.B esed os a bese, the ratio $r$ of the pack exposure for a configurotion with ap wieth d (In cantineters) to thet for Conf Iguration VI.B wes shom to fit the equation

$$
r=0.0435+0.3150 d+0.1653 d^{2}
$$

for gep withs botween 0.3175 and $1.27 \mathrm{~cm}$.

With the 91-pin subessemblies heving only one spocing in the exporim.t $(1.27 \mathrm{~cm})$, date wre not avalleble to test whether the cquetion would hold for other feal densities.

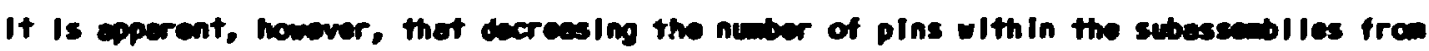
127 to 91 sebstantially Increased the pack exposure, although ranoving an additional 7 plas from the central fuel element had IIttle further offect. The Increase in the paek exposure with the si-pIn subusemblies (by a fector of 1.6 ) compared to that for the 127-pln subessemblies wes or Imerlly dwe to the redvend fuel ensity in the core of Conflguration IV.B, since, es noted in Section 7.5 .1 ebovs, the strening offects for the

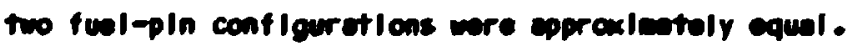

The mesured fest-neutron pak-tominime exposure ratlos for the verlous gridelote shield conflgeretions very frew 1.15 (for Conflguretion VI.B' to 1.5 (for Conflouration

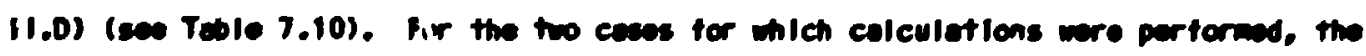

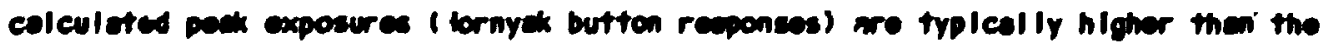

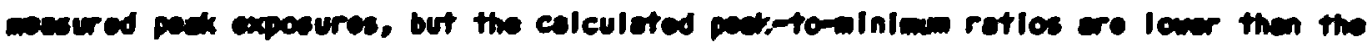
maseured ratios, wich Indleaties thet the caleuletions give a fiatter distribution of the flux ecrose the exp. Since the kormyck button response function cralleble for the celculetions had ben judged to not be cerrect, it wes not possible to estlunte how will 
Tes le 7.10. Fest-Meutron Penk-to-mialinen Exposege Rotios

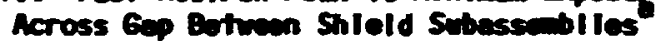

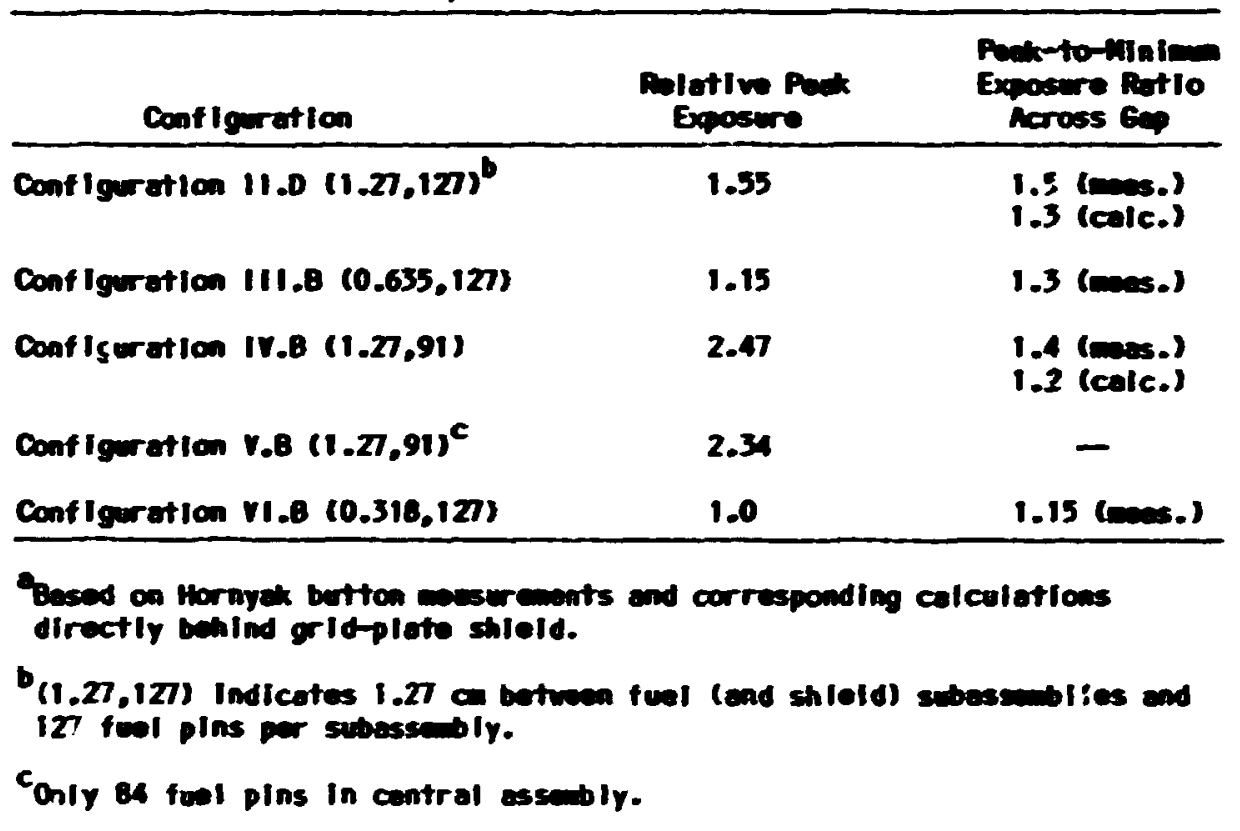

the calculetions were predicting the peak exposure. However. If It could be assened thet the DOT calculations of the fest flux Inedlately behind the coaflouration were as accurate es the DOT calculations of the totel flux $30.5 \mathrm{~cm}$ bypad the conf ignretion, then the on-axis calculated-tomeasured ratlo of the 5-In. Bonner bell responses could be used to normalizo the calculated Hormak button curve. As shom in Table 7.11, this retlo is 1.15.

hormal Izing the calculated Hornyax button response on the wis behind Conflguretion 11.0 to 1.15 times the mesured response resulted in a colculated puck exposure In the

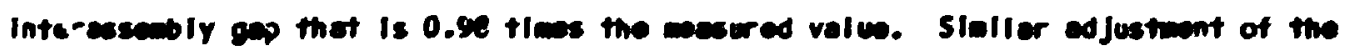
calculated response for Conflguration IV.B geve a calculated peck exposure thet wes 1.0 tines the nasered velue. Thus, If the normalizetion is correct, the colculations we in excellent corecenent with the measurements.

AI the bow revilts were, of coures, opteinad In the abeance of the grid plets Iteelf, and no sultcble mesurement schem wes devised to mesure behind the grideplete shield with the :rid plete in position. Hower, celculetions for the gridticte 
Toble 7.11. Semery of DCT-Calculated-to-knesured Dotector Responses 3yond GrIf-plate ShIeld Conf Igurat lons II.D aad IV.8

\begin{tabular}{|c|c|c|}
\hline \multirow[b]{2}{*}{ Trpe of Rasponse } & \multicolumn{2}{|c|}{ Calc. Anoes. } \\
\hline & $(1.21 .127)^{1}=$ & $\begin{array}{l}11.8 \\
(1.27,91)\end{array}$ \\
\hline \multicolumn{3}{|c|}{30.5 an Burond Configuration } \\
\hline 2-In. co-covered Bonerer ball & 1.65 & 0.95 \\
\hline 5-in. Bowser balt - & 1.15 & 1.14 \\
\hline Hornyek Sutton & 2.04 & 2.00 \\
\hline \multicolumn{3}{|c|}{305 an Beroad Cont'sgretion } \\
\hline 2-in. Cd-cowered Bonaer ball & 1.36 & 1.20 \\
\hline 5-ln. Benower boll & 1.50 & 1.50 \\
\hline Hornyek button & 2.10 & 2.08 \\
\hline
\end{tabular}

conflguration ( se Section 7.5 .3 below) shoued that with the grid plate present the peak-tominima exposure ratlo for Conflguration 11.0 would be 1.12 rether thas 1.3 . If - siniliar reduction in the easured ratio could be assined, then the mescured pack-toalnimu ratio would be 1.3 rather then 1.5 . which is certalniy an acceptable differential.

it is to be rembered, towewr, thet all these calculations were performed with a 150-angle blesed quedrature set that wey leprecticel for GCFR exign calculations. inother such a detilled quadroture set would bu necessery for calculeting the grid-piete exposure ves Investigated by perforaling en edditional celculetion for Contiguretion Il.f with a symetric $S_{10}(70$-engle) audroture. The result wes thet the locetion of the pexk

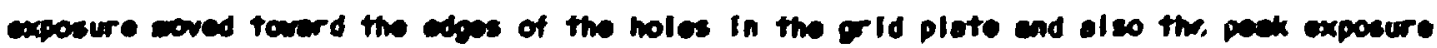
nes scommat lawer. but not signifleantiy lower. Thus it eppoers thet deslon ceiculations using the lower-order quedrature would not serlousily underpredict the puek expesure to the orid plete. 
Finally. It cen be deduced from the 2-In. and 5-In. Banner ball resilts shom in Teble 7.11 thet the lan-energy and fotal metron fluas celcolated to be Inpinging on the grid plate are eppraxinately correct. However. the hlgh-evergy fraction of the flex, es

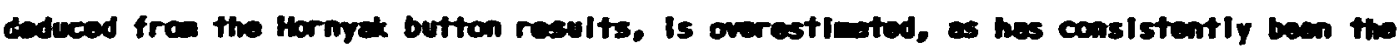
case throughout this study. As has also consisteatiy wen the case, al I detrector responses for a location $305 \mathrm{~cm}$ byond the conflgaretion are overpredictud, wich, while not directly of fecting the calculation of nestron transport through the orid plate, porteads problens with predicting the fluens beyond the grid plate.

\subsubsection{Grid-Plete Configuration}

In the TSF experiant, the reglon beyond the gr Id plate corresponded to the uppor plenum in the original CCFR design. Since much of the upper plene would consist of

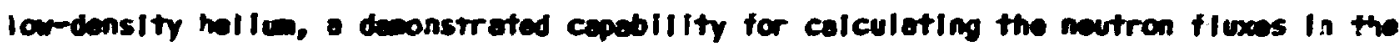
alr beyond the gridapiete section of the experimental conflguration would Indicate thet the plenum fluxes could also be calculated, wich, In turn, wuld Inp'y thet the exposure of Importent components vithin the plence could be deterinined.

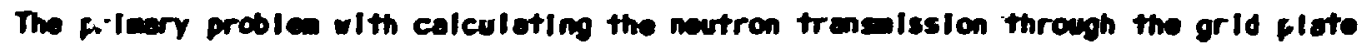
was due to the large coolent holes through It. Not only was it Inportant that these roles be adequeteiy modsied for the OOT calculetions, it wes olso important thet the angular quadrature be sufficientiy datelled to proper'y calculate the mergy and anguler distributions of the exerging neutrons, sow of which would be passing uncollided through the grid-piete holes mile others could be traversing through the full 30.5-1n. Hickness

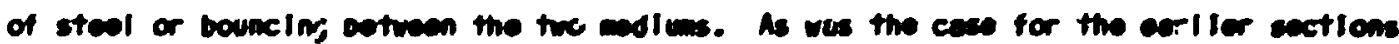
of the exper lesental conflguretion, the holes in the orid plete were aceled es las density cylindrical enoull Inrerspores between high-deasity camell, end the first c siculations wre performad alt!, the 150-angle blased quedreture.

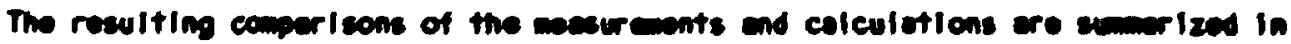
Table 7.12. As would be expacted, for the loentions clase baind the configuretion

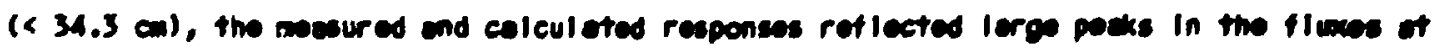
detector positione direstiy in IIm with the gridplate holes, wille for the 3asmen 
Toble 7.12. Sumory of DOT-Calculated-to-mesared Detector Responses Beyond ErId-Plate Configuration $11.0^{-}$

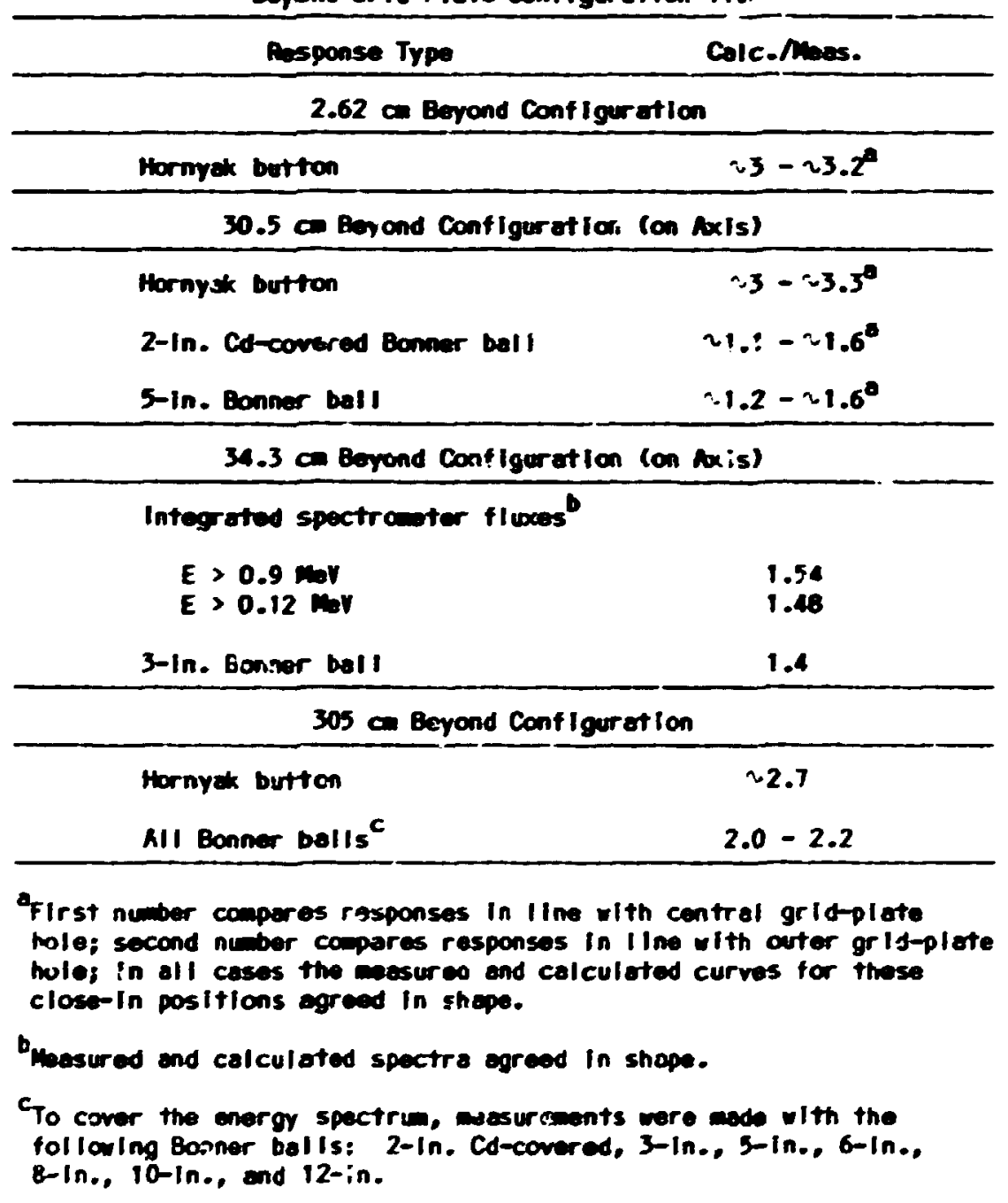

locetion the detectors viened the grid plate as a point source. Thus for the close-in positions, ratlos are given for locations corresponding to bott. holes but for the 305-can lacation only one ratio is given.

Toble 7.12 shows thet the colculations overpredict the elose- in fast-noutron fluxes (I.e.. Hornyck button responeses) by fectors of eppraxlmately 3 and the distent fluxus by - fector not wuch less then 3. With the exieption of the on-axls close- in masurements for the 2-1n. cedellum-covered Bonner boll and the s-in. Bonner ball, oll other detector responses wre elso overestinated - by fectors verylng fram 1.4 to 2.2. On the other 
had, the shapes of all the corresponding wasured and calculated curves ware In good egrement, and the curves approeched each other es the redial distence from the exis Increased.

The above comper Isons Indicate inat the calculated agoler flues in the most forvard directions we two hIgh. Ney also indicate that GCFR design colculations asling the some blased quadrature set would give extremiy sonservative resolts. But most desiga calculations had used a symetric $S_{10}$ quedrature set which had oaly 70 angles and sawe hed even used en $5_{6}$ set (30 anglas). As a result, tho adopuecy of the design calculations could not be inferred from the calculation for the experinant.

The dowe belng the cese, cre of the tasign calcalotions was recalculated with the 150-angle blased quedreture set. For a Iccution at the top center of a grisplate nole. the resulting total flux was a factor of 1.4 higher than the total flux calculated with the $S_{10}$ quadrature set and the $E>1.0$ weV floces and the $E>0.1$ hol filuces were higher by fectors of 2.2 and 1.5 respectivily. Thus the results from the blesed-quadreture ECrR design calculation were higher inen the results from the $5_{10}$ quedrature EcFR dasign colculation by approxinotely the sase factors thet the results from the biasad-quadrot re

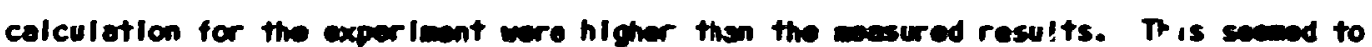
Inpir thet an $S_{10}$ quadrature alght be mare sultuble for the calculoti $n$ of the exper inent.

A recalculation of the exper inent showed thet the $S_{10}$ quadroture was totaliy Inedequate, however. the $S_{10}$ quedrature fluwe of the top of the grld plate bolmg low then the blased-quedreture fluxes by factors of 3 to 7 . At $34.3 \mathrm{~cm}$ toyond the grid plate the detector rasponses were underpredicted by factors of 4 to 12 , and of $305 \mathrm{ca}$ they were underprealcted by factors of 35 to 051 But at 305 an the $5-1 n$. Benmer bell cownt rete 122 co off the exis wes only 1.2 tiwes higher then the nesecered velue.

Since the differences botween the calculated results obtolned with the tro quedretures sets in the cerr design celculetions were not nowly so lerge these between the celculetions for the experient, It could be expected thet the eselgen celculations weuld not underpredict the fluase elthin the plemen by such Ieres factors.

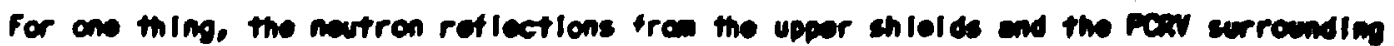


the plene would create a core unifore flux fleld in the upper pienu than wou.d exist in the open spece behind the grid plate conflguration.

In sumery. It Is concelvable that the design calculations u.derpredicted the inlet plenum fluces. Based on the above and other considerations, it is estlesate's that the $S_{10}$ quadrature design calculations woy hove underestimated the E > 1.0 mal fluxes by a factor of approxinately 4 and the $E>0.1 \mathrm{mor}$ fluoses and the total neutron fluces by a factor of epprox!nately 2.5. These factors are percelved es upper bounds to the underpredictions, and cost design constraluts for the upper axlal region wer sufficlently higher than prevluesly calculated design meutron responses that errors of this megaltude could be allowed.

\section{6. concrusions}

The results of the GCFR grid-plate shield confirmation experiment have show that axial neutron streaning in GCFR-type cores can bo calculated for a variety of fuel-pin and subassembly spacings and also thet the ation and agnitude of the paak fastneutron exposure to the grid plate can be calculated. However, current methods are Inadequate for calculating the neutron leakaga from the top or the grid plate into the upper plenum. Sirze the results of the plenum y, julstion were sensitive to the quadrature set used, empnesls should given to the development of an epproprlate quadrature sot for plentw-type salculations.

\subsection{REFEREUCES}

1. D. T. Ingarsoll, F. J. Muckenthaler, C. O. SIater, and H. L. WIIIIas, WGid Plate

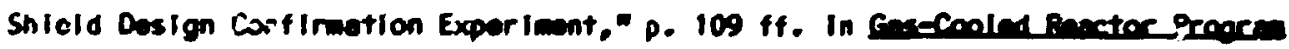

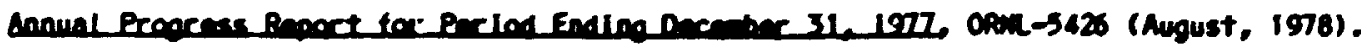

2. F. J. Muckenthaler, j. .. Hull, and J. J. Menning. The CorR Grid Plate Shleld Design Conf Irmstion Experiment," coul/Tw-63e0 (denuery, 1979).

3. C. O. Sieter, S. N. Crawer, D. T. Ingorsol I, M. L. WII II lans, F. J. Muckentheler, J.

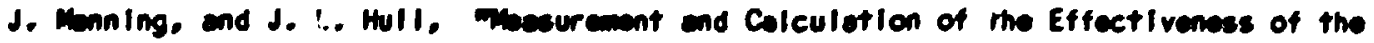

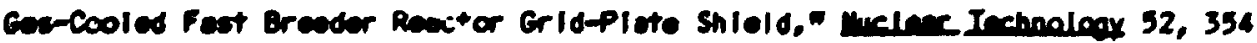
(1981). 
4. C. O. Slater. S. N. Cramer, and D. T. Ingarsol I, Analysis of the CRerTSF GCFR Grid PIote Shield Design Confirmation Experimont," Iranse An. Mal. Sac. 32, 641, 1979.

5. C. O. Slatcr, S. N. Cramer, and D. T. Ingersol I, MAmalys Is of the MPaU/TSF GCFR GrId-PIate Snleld Design Confiration Expericant, Opol-555i (ingust, 1979).

o. R. E. Moerker and F. J. Muckenthaler, Whe Absolute Noutron Spectru Enarging Through the Large Baca Collimator frow the TSR-II Reactor at the Tover Shlelding Faclilty." OPu-TH-5183 (January 1976 ). 
8. GCFR RADINL BLAMET MO SHIE.D INTEGRNL DXFERIMEMT

Ext: ariment performed by:

F. J. Muckenthaler, J. L. Hul I, J. , Monning

Analysis performed by:

J. T. Ingersol I, L. R. Will Ilams

8.1. Introduction

8.2. The Exper Imont

8.3. Proenalysis an j Experimental Design

8.4. Postanalysis of the Exper Iment; Comporison of Calculated and Moarured Results

8.4.1. Definition of Source

8.4.2. Transport Calculations for spectron yoditler

8.4.3. Transport Calculations for Blanket Configurations

8.4.4. Frensport Calculations for Shield Conf !gurations

8.4.5. Examination of Gama-Ray Spestral Discrepancies

8.5. Conclusions

8.6. Reforences 


\subsection{INTROOUCTION}

Wherees the exper Iments described in Chepters 5 throogh 7 wore designed th study the ef fects of neutrons streening upward through vertical $: .1$ lum-cool ant pessegreys in the GCFR corc, out the top of the core, and on through largs holes in the grid-plate shield, the experimant described in this chepter uas designed to study the ef fects of noutrons leaving the core in the racia: direction and panatrating through thick and dense Iasinated regions. More specifically. the experimont ues cosigned to verify the effectivenes: of the GCFR radial shiald in protecting the prestressed concrete reactor ressel (POW) fro radiation dasage.

The design of the GCFR redial shield hed been speclified in consldarble detall and designated as Conceptual Shlelding ConfIguration 1 (CSC.1). As shoun In FIg. 8.1 and Tade 8.1. the shielding consisted of a removeble Innor shioid (in two raus) and a permanent outer shield. The first row of the Inner shleld consisted of boroneted graphite clad wth stainless steel and the second row consisted ontirely of stainless steel. The permanent outer shleld conslsted of graphlte bounded on sech sl de by boronated graphite and clad with stalniess steal. These shlelds were to Ilalt the total IIfetime fluence at any polnt In the FCoy to less then $10^{19}$ neutrons par squere centlater, and COFR design calculations at General Atailic and at Opan hed Indicated that this criterion could be not If the first row of the Inner shleld cere repiaced every three years and the second rou every six years. However, a nuber of uncertalntles existed in the design and it was importer, thet the rangs of the uncertainties be brecketed - and narrowed if possible - In order te reduce costs resulting tran excesslve design conservatise.

The uncertalint'es of wost concern were those essocl ated with the nutron crose sections used in the design calculations. Inile cerller TSF experients hed provlded date to test the cross sections newed to calculate dup neutron ponotration In Iron and stainless steal (rots. 1 and 2), the neutron dote requires for the grephlte cons boronend grephite regions hed not been siollerly checked. norcover. lerge uncertalntice tere asecelated with the noutron cross sections ued in calculeting the trensport through the 
ORNL-OWO 91-12293

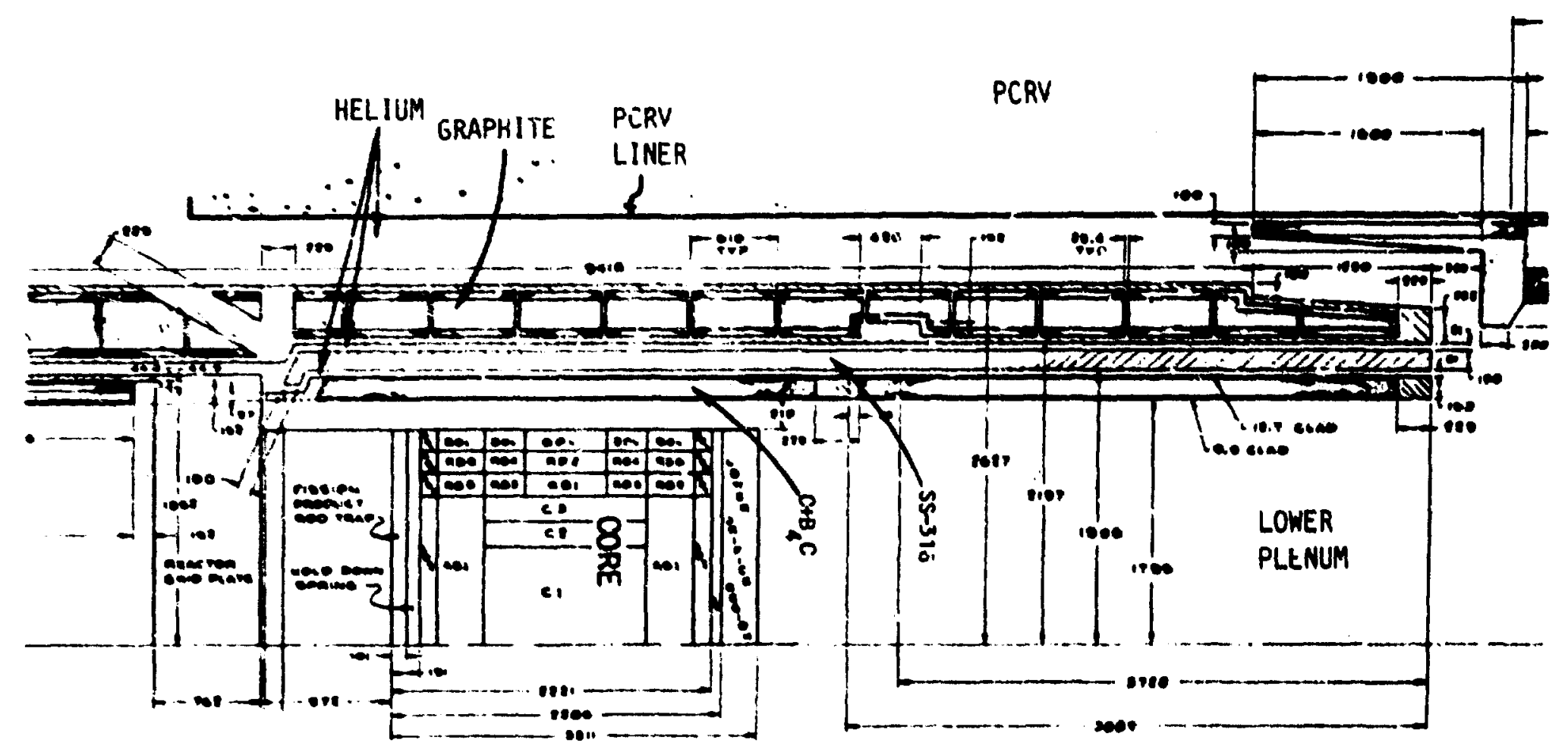
cont Iguration 1 (CSC.1). 
Toble 8.1. Gometry and Mrteriels for Concoptual Shlelding Configuration 1 (CSC. I) of the Cors Midpiane Level

\begin{tabular}{|c|c|c|c|c|c|}
\hline \multicolumn{3}{|c|}{ Puglon and Vuterial } & \multirow{2}{*}{$\begin{array}{c}\text { Ianer Redius } \\
\text { (c) }\end{array}$} & \multirow{2}{*}{$\begin{array}{c}\begin{array}{c}\text { Orter Rodlus } \\
\text { (con) }\end{array} \\
\begin{array}{r}77.9 \\
96.9 \\
115.6\end{array}\end{array}$} & \multirow{2}{*}{$\begin{array}{c}\begin{array}{c}\text { Misknoss } \\
\text { lomi }\end{array} \\
\begin{array}{c}77.9 \\
19.0 \\
18.7\end{array}\end{array}$} \\
\hline a.- & $\begin{array}{l}\text { Erricheon } \\
\text { Earlichnon } \\
\text { Earlichmen }\end{array}$ & $\begin{array}{r}+2001 \\
+20002 \\
+20103\end{array}$ & & & \\
\hline Radi al & Blanket: & $\begin{array}{l}\text { Row 1, } w w_{2} \\
\text { Row 2, } 10_{2}^{2} \\
\text { Row 3, } v 0_{2}\end{array}$ & $\begin{array}{l}115.6 \\
134.1 \\
152.6\end{array}$ & $\begin{array}{l}134.1 \\
152.6 \\
171.0\end{array}$ & $\begin{array}{l}18.5 \\
18.5 \\
18.4\end{array}$ \\
\hline Fist to & Gep & & 171.6 & 194.0 & 23.0 \\
\hline Inner & Shleid 1: & $\begin{array}{l}s s-316 \\
c+B, c \\
s s-316\end{array}$ & $\begin{array}{l}194.0 \\
195.0 \\
29.7\end{array}$ & $\begin{array}{l}195.0 \\
207.7 \\
209.0\end{array}$ & $\begin{array}{r}1.0 \\
12.7 \\
1.3\end{array}$ \\
\hline Hol in & Gep & & 209.0 & 214.1 & 5.1 \\
\hline Inner & Shield Z: & $55-316$ & 214.1 & 229.1 & 15.0 \\
\hline Hel Iun & Gep & & $229 . i$ & 234.2 & 5.1 \\
\hline Oirter & Shleld: & 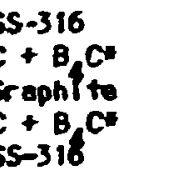 & $\begin{array}{l}234.2 \\
239.3 \\
244.4 \\
267.0 \\
272.1\end{array}$ & $\begin{array}{l}239.3 \\
244.4 \\
267.0 \\
272.0 \\
277.4\end{array}$ & $\begin{array}{r}5.1 \\
5.1 \\
22.6 \\
5.1 \\
5.1\end{array}$ \\
\hline Hation & Gap & & 277.2 & 312.9 & 55.7 \\
\hline PCRV L & Iner: $F$ & & 312.9 & $\vdots 14.7$ & 1.8 \\
\hline PCRY & & & 314.7 & & \\
\hline
\end{tabular}

.25 int.5 boron mixture of grephlte and B.C at 1.6 g/ce bulk dansity.

thorl as blanket region, whlch, of course, Introduced uncertalintles in the source calculated to be Irolinging on the inner surface of the radial shleld. Finally, the uncertulinties in the neutron cross sections introducod uncertainties in celculations of the production of secondery gand roys and the essceleted emerg depost+!on throughout the contlguration.

A mejor uncertalinty also lay in the cec.l sesign Itealf, since even as the experimant wes beling plannod, modiflcotions to the daslgn were under consideration. In particuler, en "upflicw GCTR" wes boing proposed whish would necessitate chenges in tils

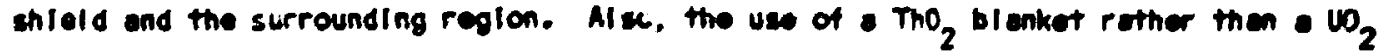
blenket was bolng suggested, which, of courso, would of fect the source Inplinging on the 
shield. In the besence of en alternate design, lowever. the CSC.I design wes retolmed as the basl: for the exporimentel design. Ith the chjectives of the exper Imont statiod es fol lous:

(1) To verify the eccerey of the nucleer data used In the design calculations,

(2) To def ins experimantal and endytic uncertalnties in terns of their Inpl Icatlons to design calculations and deslgn criterla, and

(3) To provide experientel comperisons of the salelding effectivenss of el ternate shield ceslyns.

As was the sase with the grid-plate shield conf Irmation experimert, the design of the experimental configuration was completed only after a detalled preanalysis had Indlcated that the conf lour ofion would meet its objectives. The preanalysis calculations ere sunarlzej here In Saction 8.3, following a description of the experinent Itself In Section 8.2. A core datalled description of the freenalysis is presented In two cove GCFR progress reports (refs. 3,4), In a paper presenter to the har Ican Nuclear Soclety (ref. 5), and In a toplcal report (ref. 6). The expe-iment is el so cescribed in the clfed propress reports and in a too!cal report (raf. 2). The finol analysis of the experlaent Is sumorlzed in Section 8.4 and is presented In nore detall in refs. 8 - 10.

\subsection{THE EXPERIIEN}

The GCFR radial blenket and shleid experlenent wes parformed at the Oail Tower Shielding Facility in 1979 , Werch through September) w:th an exper imental configuration thet Included mockups of the bianket reglon, the Inner and outer radial shlelds, and o portion of the PCRV. As III the corller experimonts. It was nocessery to modlfy the spectron of the neutrons energling from the TSA-II colliated boen so thet it would resemble the spectron of noutrons that would be curgling from the eche core, thls time those noutrons leaving the core In the resilal direction. Calculations performed during the prearalysis of the exper!ment (see Section 8.3) Indleated that the desired spectrum could bo obtelind by flltering the bee through $10.2 \mathrm{ca}$ of Iron, $9 \mathrm{~cm}$ of aluincm, end $2.54 \mathrm{~cm}$ of Boral, therefore a spactrum nodifler Including thoce materials was Inserted In the been adjecent to the TSA-II shleld-collimetor. The Individual sicbs used in the 


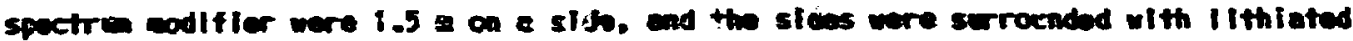

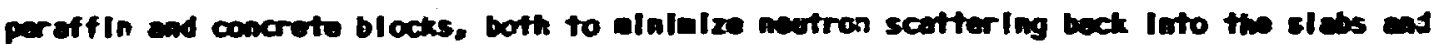
to aduce the beckgrusas at the setectors. The resulting conf Iguration, Ideatlfied es Donfiguretica I.A, Is stion In FIg. a.2.

As shown In Tobla 3.2, Donf Igurution I.A wes the f Irst of 24 cont Igrretlons Incl ednd

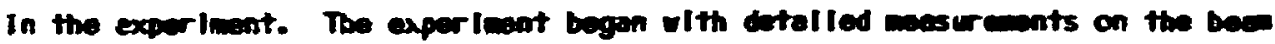
centerline of verlous distences boyond this configuetion, the mesuremente Inciudims

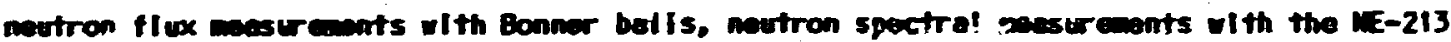
spectroneter and the hyorogen counter, and gaweray spectral masure onts alth the lic-213 spectrometer.

Next, two types of blenket conf Iguratlons were tested - ase that used slebs of Tho wich wes the elternste mater iel weing considered for the CCFR blenket, and another that used siabs of $\mathrm{CO}_{2}$, which was the meterlal speifled In the CSC.I dosign. Agala the slabs were 1.5 a on a slib and wore surrounded by lithlated paroffin and concrete, os were ail the orther moterials subsequently added to the conflgurations.

onint-ons re- ise es

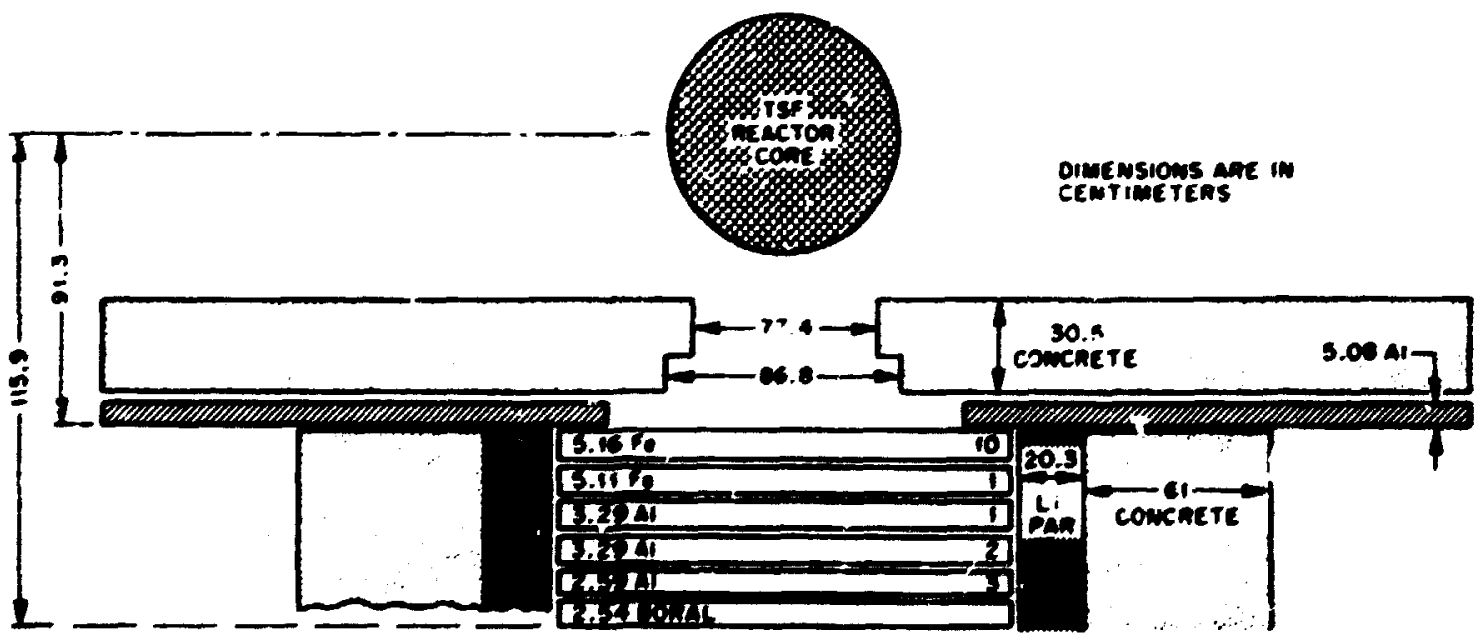

FIg. 8.2. Mockup of Spectrum Modifler Surrounded by LIthleted Paraffin and Concreto conf lgur otion I.Ai. 
Teble 8.2. Sumory or Conflgur oflans and Mmasurements for GCrR Rodi ol Blanket and Shleld Experinent

\begin{tabular}{|c|c|c|}
\hline Conf Iguration & Description" & Mensuruments \\
\hline I.A & Spoctrin modifler (Sil) only & 80,5 \\
\hline I.B & $\mathrm{Sil}+1 / 2 \mathrm{MHO}_{2}$ blenket rom & B.5 \\
\hline I.C & $\mathrm{SH}+1 \mathrm{ThO}_{2}$ blenket rou & 88 \\
\hline I.D & $\mathrm{SH}+2 \mathrm{ThO}_{2}$ blanket rous & $8 B, 5, \pi 0$ \\
\hline I.E & $\mathrm{SH}+3 \mathrm{ThO}_{2}$ bl anket rous & $B, S, \cap L D$ \\
\hline I.F & Conf. I.5 + Fe ref lector & no \\
\hline II.A & $3 \mathrm{\omega O}_{2}$ blanket rows & $B 8, S, \pi D$ \\
\hline II.B & Conf. W.A + reference Inner shleld & ES,S \\
\hline IU.A & $\begin{array}{l}\text { Conf. l.E + boronated graphlte (first } \\
\text { row of inner shleld) }\end{array}$ & 68,5 \\
\hline $111 . \mathrm{B}$ & $\begin{array}{l}\text { Conf. III.A + stainless steel } \\
\text { (completIng reference Inner shield) }\end{array}$ & $B 8, S$ \\
\hline IV.A & Conf. $111.8+1 / 3$ reference outer shleld & $\mathbf{E B}$ \\
\hline IV.B & Conf. III.B + 2/3 reference outer shleld & $\mathbf{E B}$ \\
\hline IV.C & Conf. III.B + reference outer shleld & B8,S \\
\hline IY.O & Conf. IV.Z + Fe + concrete & EB, RD \\
\hline IY.E & $\begin{array}{l}\text { Reference Inner and outer shlelds (blanket } \\
\text { removed) }\end{array}$ & 88,5 \\
\hline Y.A & Conf. II.A. (repeat) & $\mathbf{B 8}$ \\
\hline $\mathbf{V . B}$ & Conf. V.A + grephlte & B8, S \\
\hline V.c & Cont. V.B + boronated graphite + steel & $8 B, S, T D D$ \\
\hline V.D & Conf. V.C + steel & BB, RLO \\
\hline V.E & Coiff. V.A + boronated graphite + steel & $8 \mathbf{B}, \mathbf{n O}$ \\
\hline VI.A & Lead only & $\mathbf{S}$ \\
\hline VI.B & Lead + spectrum moditler & $\mathbf{S}$ \\
\hline VI.C & $\mathrm{wO}_{2}$ only & $\mathbf{s}$ \\
\hline VI.D & $\mathrm{WO}_{2}+$ spectrum modifler & 68,5 \\
\hline
\end{tabular}




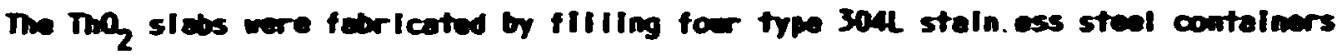

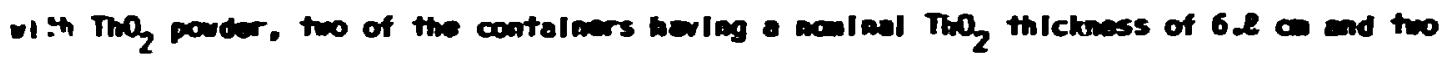

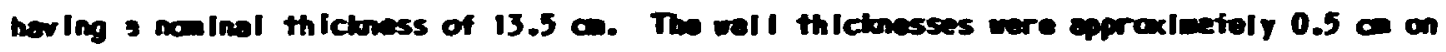
the thisuer contelmars ead approxinately 1 on on the thicker contelners.

Four $\mathrm{ma}_{2}$ blenket conflgererions were tested, epproxinating one-balf, an, two, ad thres blanket rous respactively (Conf Igrations I.B, I.C, I.D and I.E). Bonaner bal I

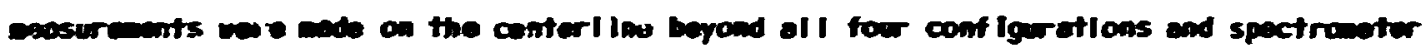

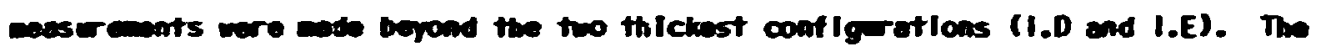
arrangments for Conf Igrutions I.B. I.C, and I.D are shoun In Fig. 6.3 and the arrengowent for Conf Iguretion I.E Is shown In FIg. 8.4.

In Conf Ifur et lons I.D and I.E, energy deposition meosurements with in the conf Igur ations wre also wode. For these, therwol winescent detectors (TDS) wore positioned in the wolds between the blenket slabs. So that the moesurements could be obtained at approximetaly 7-ca intervals along t... axis of the blanket region, the order cf the thick and thin $\mathrm{ThO}_{2}$ slabs in Conf Iguration 1.0 ves revisod before an additional thick slab was added to form Configuration 1.E. And, tInally. In ordar to increase the number of ILD ecesurement points even nor \&, en additional conf Igur ation (I. f) wes formed oy rearrangling the $\mathrm{ThO}_{2}$ slabs of Conflgur etion I.E. The reerrangad configur of ion endad with - thin slab and $25 \mathrm{~cm}$ of Iron. Ading the Iron allowed a RD measurement to be ade lasediately betind the blanket region, the odditional Iron beling necessery to simulate an Infinite modiun.

The $\mathrm{UO}_{2}$ slabs used for the alternate blankat conf Igur atlons had been fabricated for earlier (LWFR) experinents and they Included sam moterlals that would be forelgn to the GCFR, in particuler, signlficant amounts of ol uinu and sodicn. The "slabs" were Iron

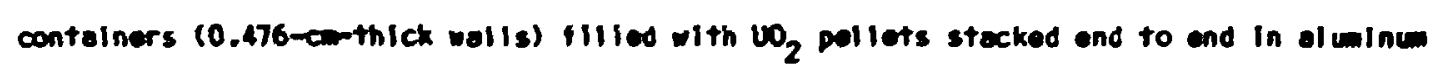
tubes. The tubes were positioned vertical iy on a triangular pltch with in the contalners, with the vols between the tubes fllled with sodiun. The thickness of the slabs was 10.1 cm. with the $\mathrm{w}_{2}$ comprieing 64.68 of the volum. The oluminu conprised 11.2 vol.8 and the sodiun 23.2 vol.s. The remalning 1 vol.s consisted of an pron-fllled spece between the $\mathrm{w}_{2}$ pallets and the aluinu tubing. 


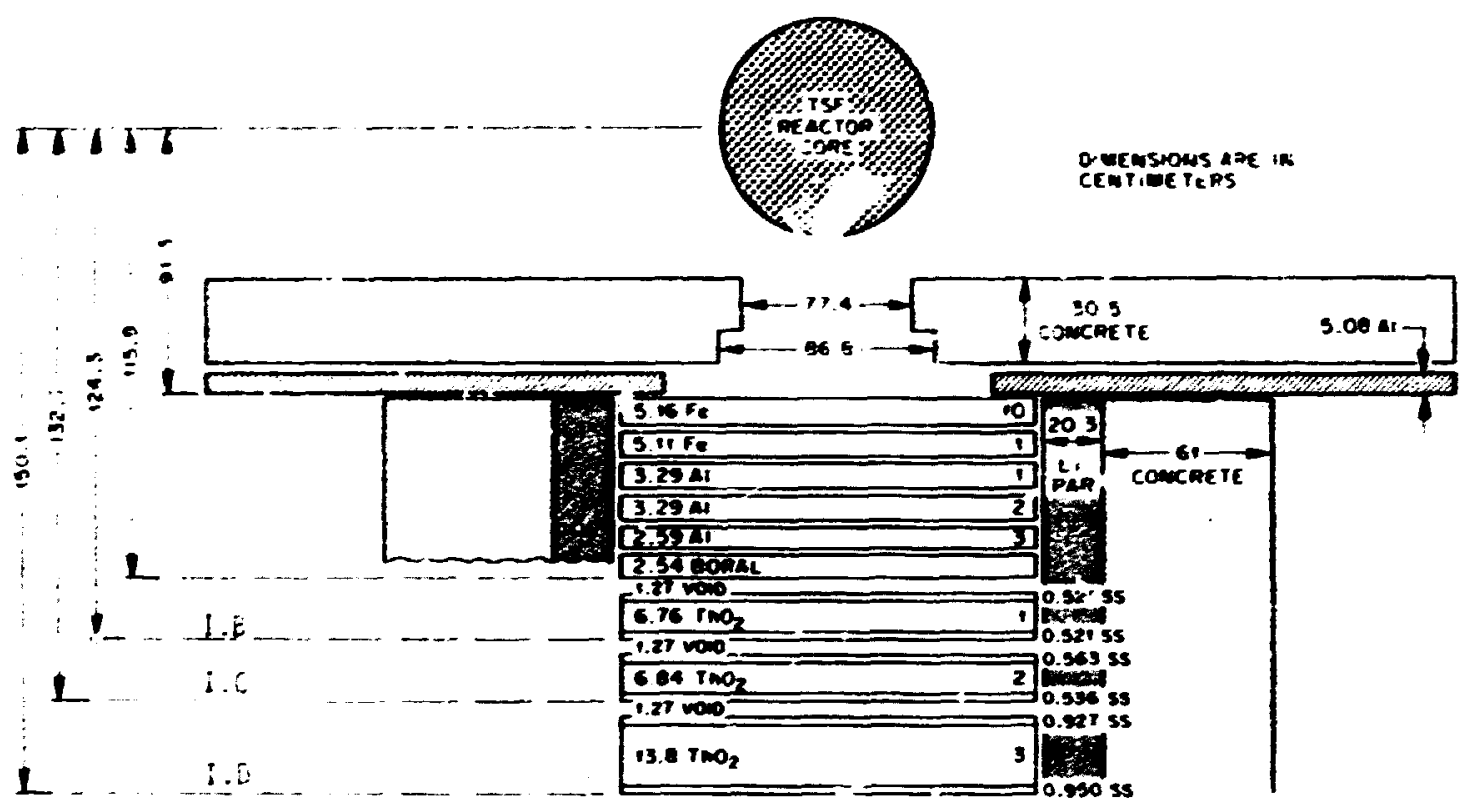

Fig. 8.3. Spectrum Modifier and One-Half, One, and Two ThO 2 Radial Blanket Rows (Dont igurations I.B, I.C, and I.J).

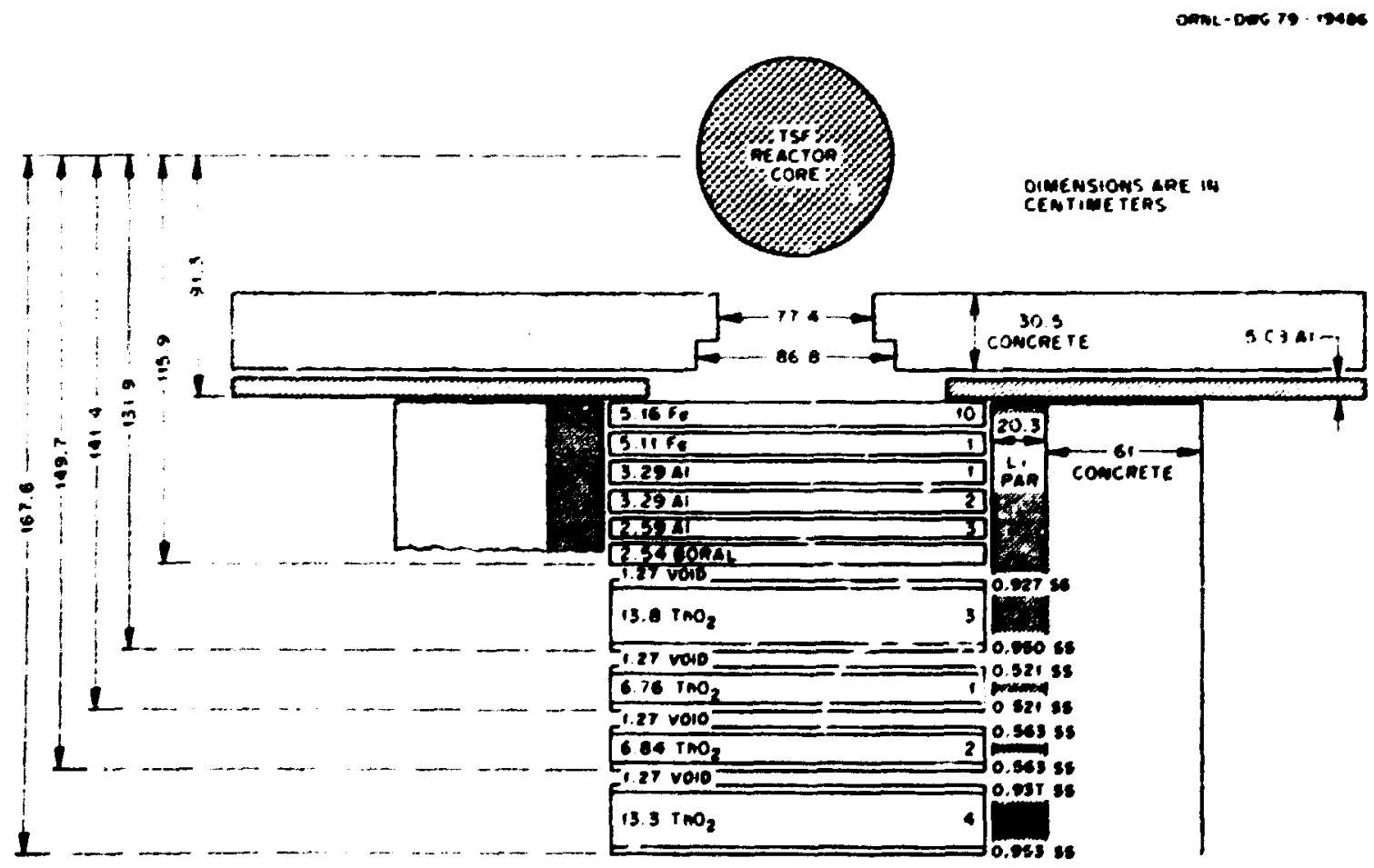

Fig. 8.4. Spectrum Modifler and Full ThO 2 Radlal Blanket (Three Rows) (Cont lguration $[, E)$. 
Oniy one $\mathrm{UO}_{2}$ blanket configuration $(11 . A)$ was fested, and it consisted of three of the 10.1 -co-thlck $\mathrm{WO}_{2}$ slabs behind the spectrum modifler (see Fig. 8.5). A full complement of measurements was made beyond the conf iguration and hD meesurements rere made within the volds between the slabs.

Fol lowling the measurements with the blanket mockups, three conf igurations ith mockups of the GCFR inner shleld wore tested. As noted in Tatle 8.1, the CSC.I dasign specifled that the first row of the Inner shield would consist of 1 an of stalniess steel (type 316), $12.7 \mathrm{~cm}$ of a wxture of graphlie and $\mathrm{B}_{4} \mathrm{C}(25 \mathrm{wt.8}$ boron), and $1.3 \mathrm{~cm}$ of stainless steel. The second row, to be separated from the first by a 5.1 -a hellim gas. would consist of $15 \mathrm{~cm}$ of the steel.

In the experiment the first row of the inner shield was sialatec by flliling a rectangular stainless steel contalner (Ins'de thickness of $14.45 \mathrm{~cm}$ ) with a mixture of $B_{4} C$ powder and powdered graphite. Analyses for tha boron content gave a spread cf 26.18 to 27.15\%. The stainless steel wall thlcknesses were $1.40 \mathrm{~cm}$ on one slde and $0.953 \mathrm{~cm}$ or. the other. The second rom of the inner shield was simulated with three type 304 stainless steel slabs, each about $5 \mathrm{~cm}$ thick.

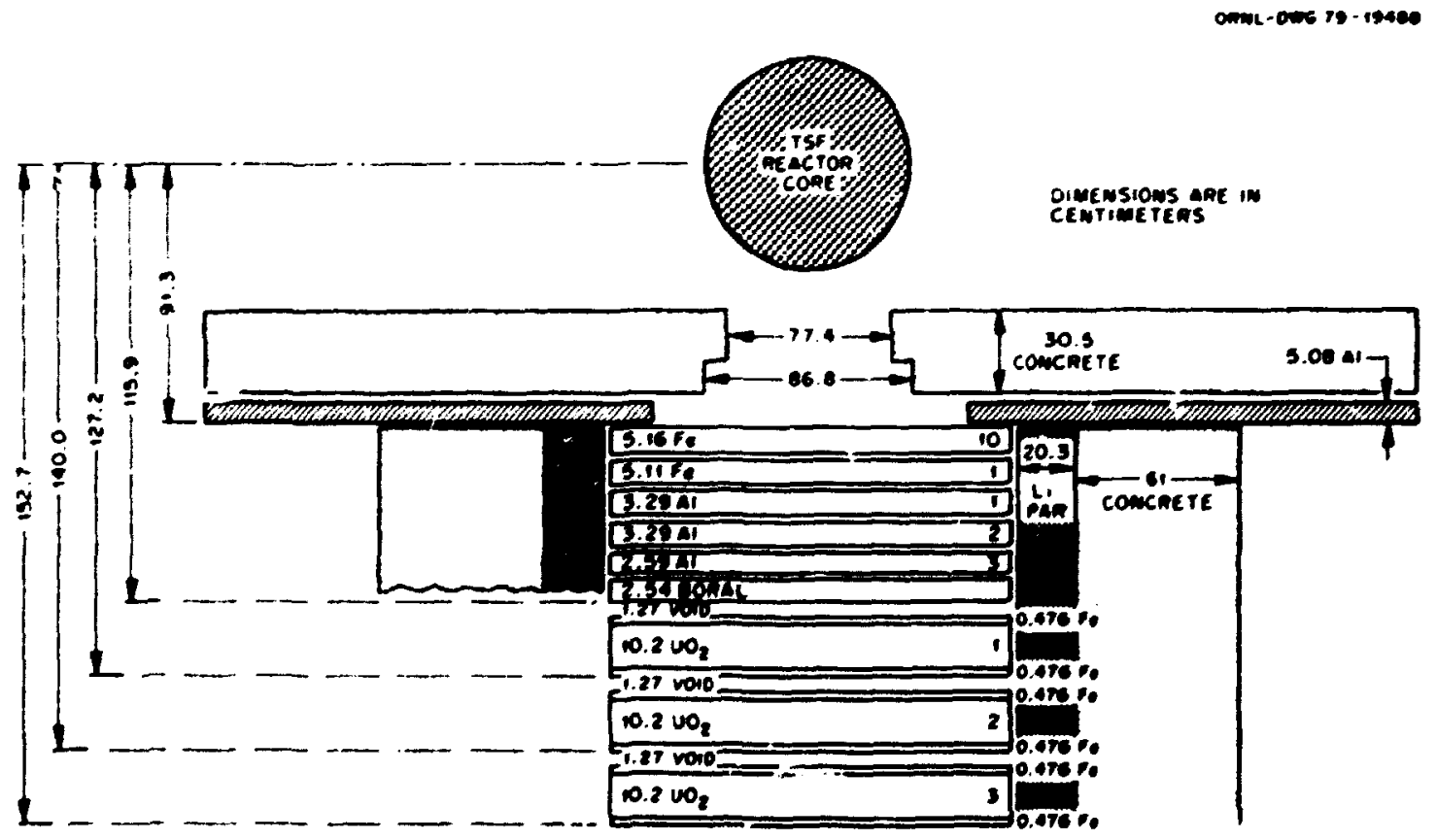

FIg. 8.5. Spectrum Meditler and UO 2 Redi ol Blanket (Contiguration II.A). 
For the first inner shield conf Iguration, the $\mathrm{UO}_{2}$ blanket conf lguration was exterded vith a nockup of both raus of the Inner shield (Configuration II.B as shown In FIg. 8.6). Next, the $\mathrm{CO}_{2}$ blenket was replaced with the full $\mathrm{ThO}_{2}$ blanket, and only the first rou of the Inner shield was used to for Configuretion III.A (see Fig. 8.7). Finaliy, the second raw of the Inner shield was added, simulating the full CSC.I bienket and Inner shield In Configuration III.B. Masuremenis were mode beyond, but not within, all these conf I gur ations.

The next three conf lgurations In the experiment resulted from the sectionsi bull dup of ackup of the GCFR outer shield. Table 8.1 shows that the CSC.1 cuter-shield design cons:sted of $5.1 \mathrm{~cm}$ type 316 stalnless steel, $5.1 \mathrm{~cm}$ of the B,C-graphite alxture, $22.6 \mathrm{Ca}$ of graphite, another $5.1 \mathrm{~cm}$ of the B, C-graphite alxture, and a IInal $5.1 \mathrm{Co} 0$ type 316 stainless steel.

In the first cuter-shield conf Igur ation in the experiment the Innermost porrion of the outer shleld was sime! ated with a 4.7-can thickness of type 304 stainless steel plus an epproximately 5-C thickness of the $B_{4} C+$ grapilite wixture in a stainiess stael contalner (type 304L) whose valls were $0.95 \mathrm{~cm}$ tr.Ick on one slde ans: $31 \mathrm{~cm}$ thlck on the other. ThIs conf Igur ation was designated as Conf Igur atlon IV.A and represented the CSC.I design through an outer radlus of $244.1 \mathrm{~cm}$ isee Table 8.11. Its boundarles are shown in FIg. 8.8 .

In the two following conf Igurations (also deplcted In FIg. 8.9) a $22.3 \cdot-\mathrm{cm}$ thickness of solid graphite was added for ConfIguration IV.B, and a second approximately 5-carthIck stalniess steel contalner fllled $1 \mathrm{lth}, \mathrm{B}_{4} \mathrm{C}$ and graphlte plus $4.5 \mathrm{~cm}$ of stainless steal were added for ConfIguration IV.C. Bonner ball mesurements were made beyond all three radiai shield configurations. In addition, spectral measurements wero attempted behind Configuration IV.C; however, the low neutron intensity bahind the contiguration made the NE-213 data questionable and the hycrogen counter dato unusable.

Two additional conflgurations were Included in the serles of outer radial shleld tests. In cne (Conflguration IV.D In FIg. B.i,) a mockup of a portion of the PCRV was placad behind the radial shleld with in Intervenlng 35.6-cen vold. Bonner ball measurcanents were made in the wlejie of the vold and KLO moesurements were made on each 


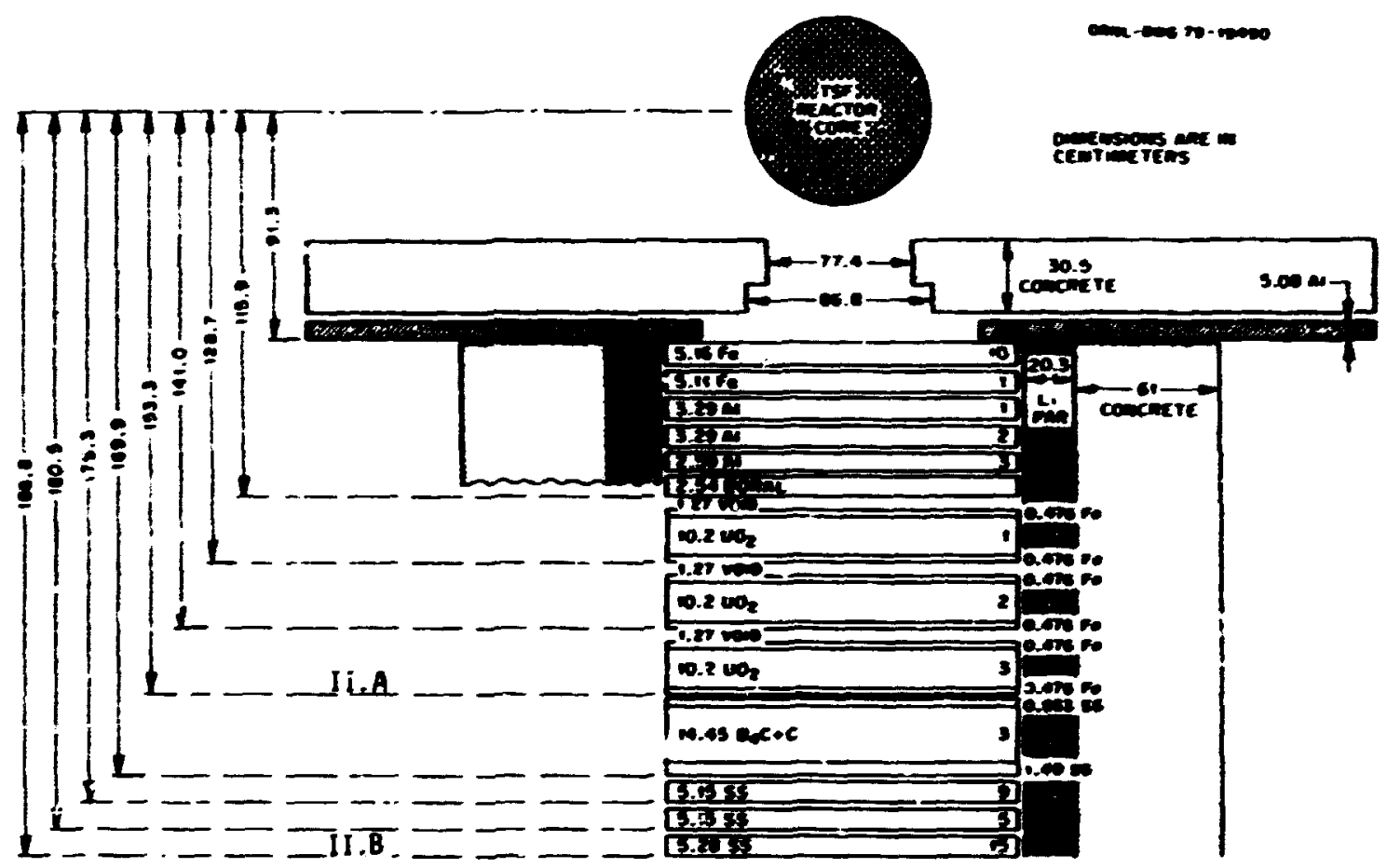

Fig. 8.6. Soectrum Modifler, $\mathrm{O}_{2} \mathrm{Rad}$ al Blanket, and Inner Radial Shleld (ConfIgur at Ion $(1,8)$.

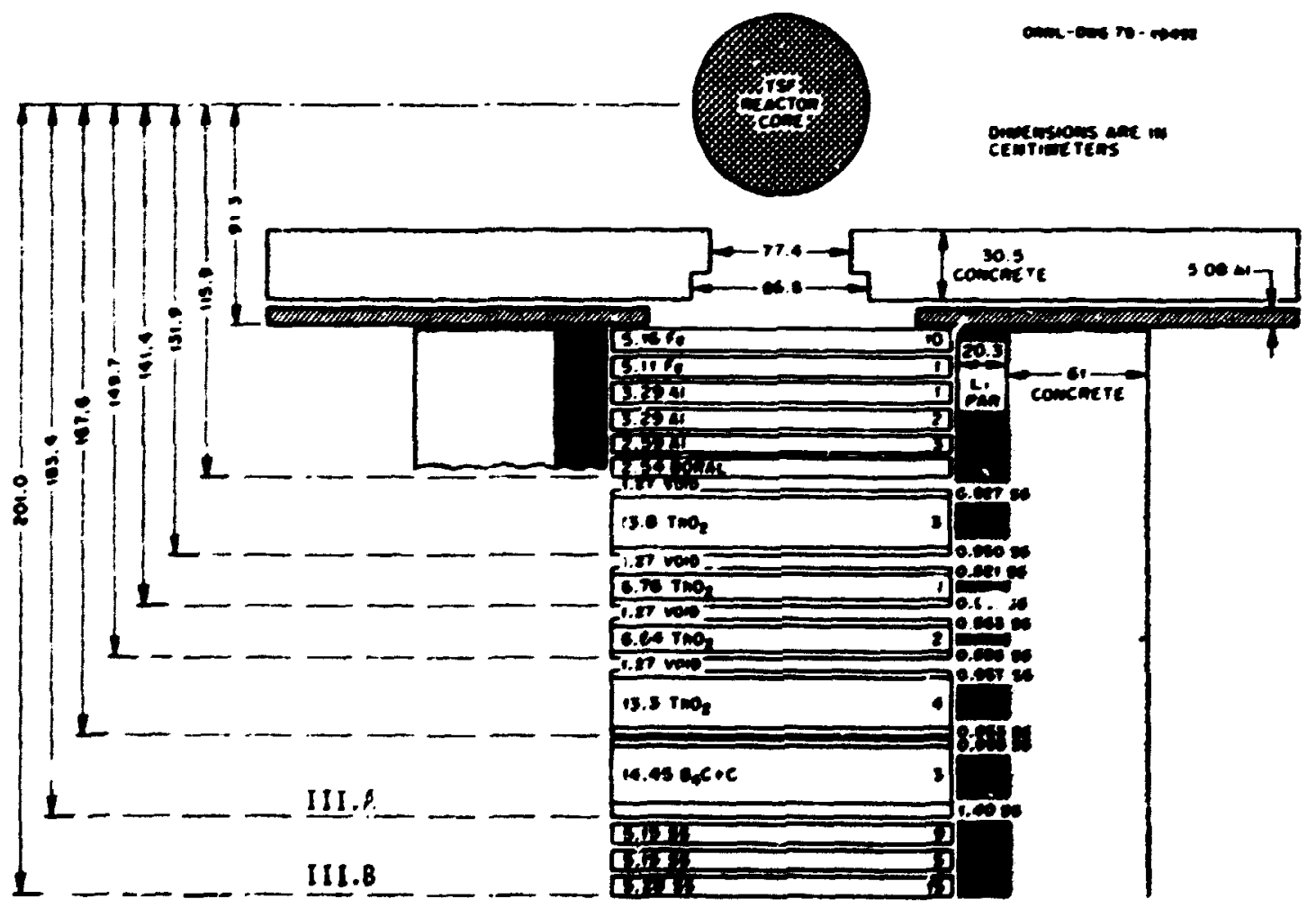

Fig. 6.7. Spectron modifler. Tho, Rodial BIanket, First and Second Rows of Inner Redial Shield (Conf Igur otions III.A end III.B). 


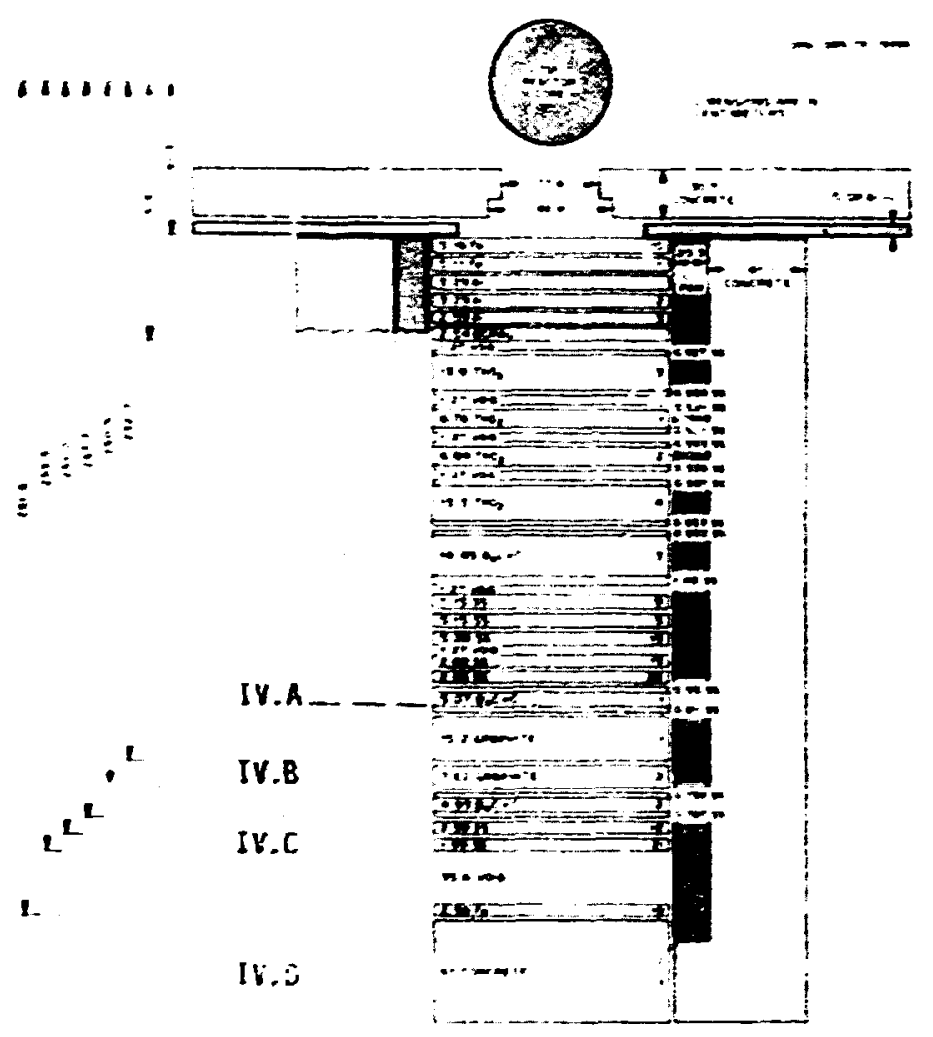

Fig. 8.8. Spectru Modifler, Tho, Radlal Blanket, and Increasing Thicknesses of Inner and Outer Raclai St.lelds (Conflgirations 1\%,., It.B, and IV.C); PCRV Mdded (Cont Igur atlon (V.D).

slde of the 15.2-cm thlckness of stainless steel and agalnst the front face of the Iron Iining the PCRV. In the other conflguration (IV.E) the blenket region preceding the Inser and outer shle:d nockups was $r$ soved to increase the neutron Intensity beyond the configuration and allow spectral masurements to be made.

To fulfIll Objective 3 as given In Section 8.1 bbove, mesureants were ai so made beyond alternate Inner shlgid contlguratlons. It had been planned that the biankat region in these additional configuretions vould be comprlsed of the $\mathrm{ThO}_{2}$ slabs, but zalculations parforiad during the course of the exper Iment and cescribed bolon has revealed lerge olscrepancles between the calculated ano weasured results for the

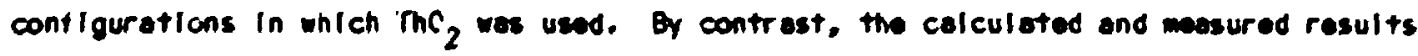
for conflguretions In which the $\mathrm{LO}_{2}$ slabs comprised the ol enket region were In good agreaments therefore, It was declded to use $\mathrm{UO}_{2}$ in the alternate-shleld contiguratlons. These configurations were Identifled as Conf Iguratlons V.A - V.E and are deplcted In Figs. $8.9-8.11$. 


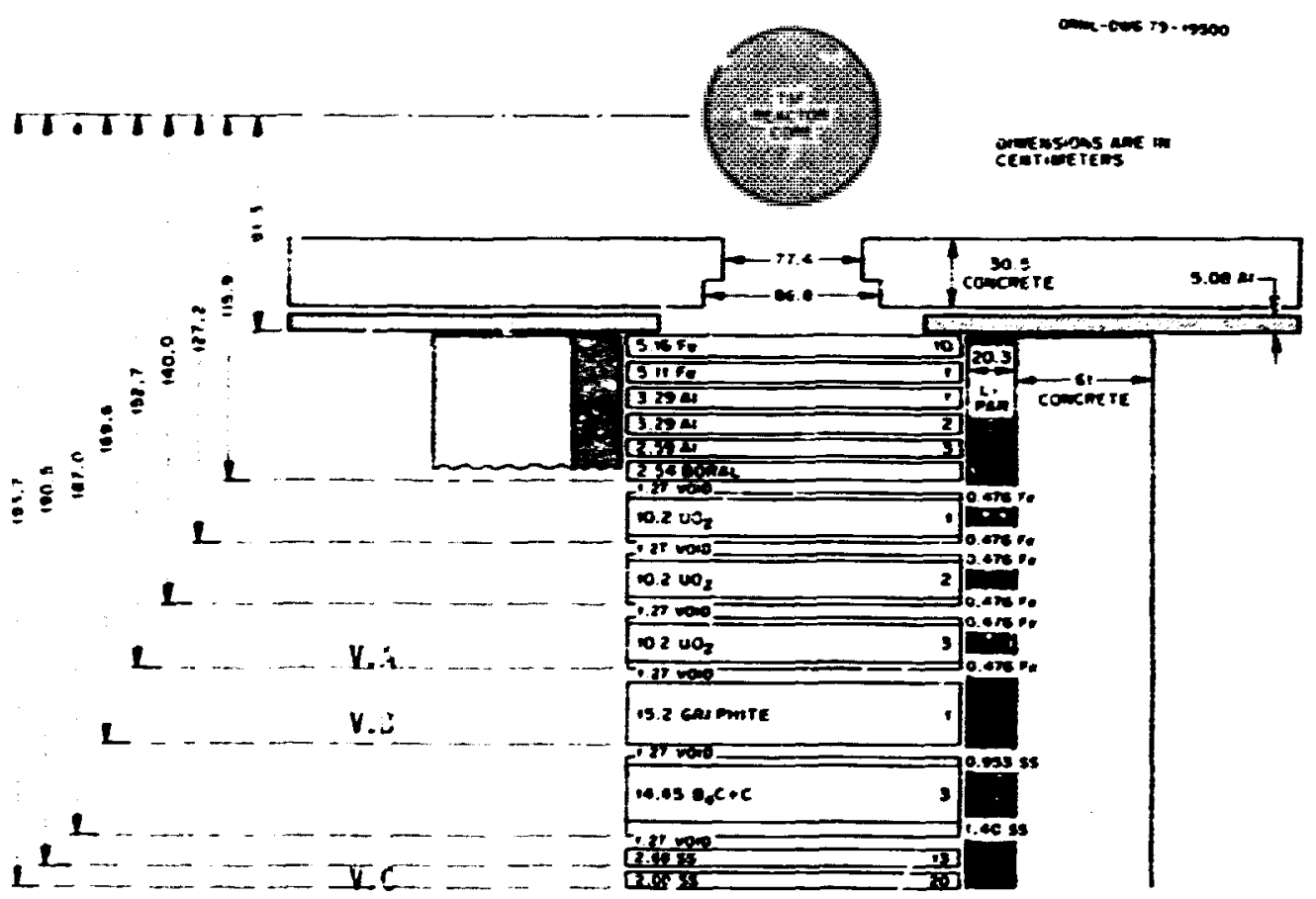

Fig. 8.9. Spectru Modifler, Wo, Radial Blanket and Phases I and II of Alternate Inner Radial Shielo (Conf Igurations V.A, V.B, and V.C).

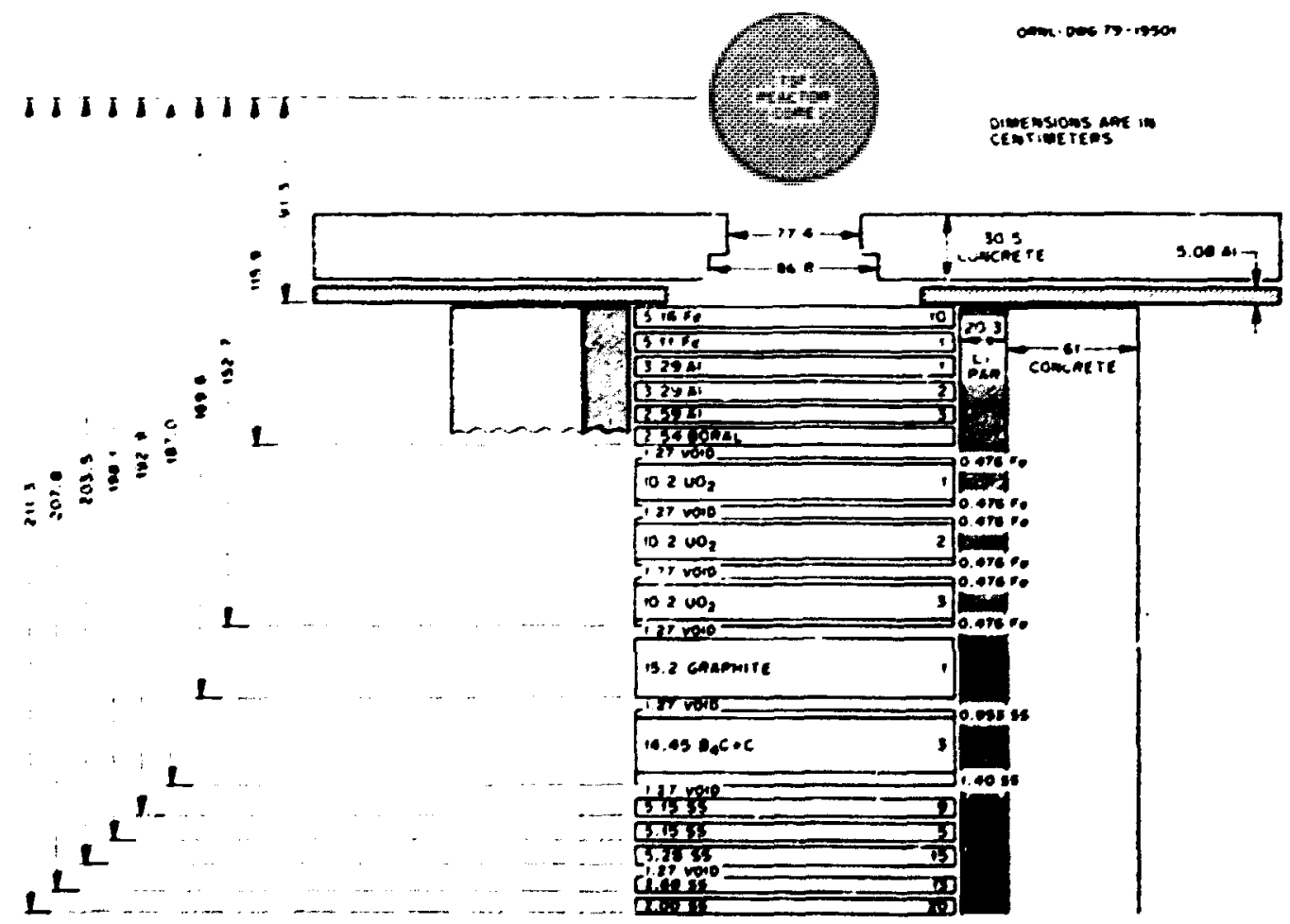

Fig. B.10. Spactrum Modifler, $\mathrm{NO}_{2}$ Redial Blanket, and Phase 111 of Alternate Inner Radial Shleld (Conf Iguration V.D). 


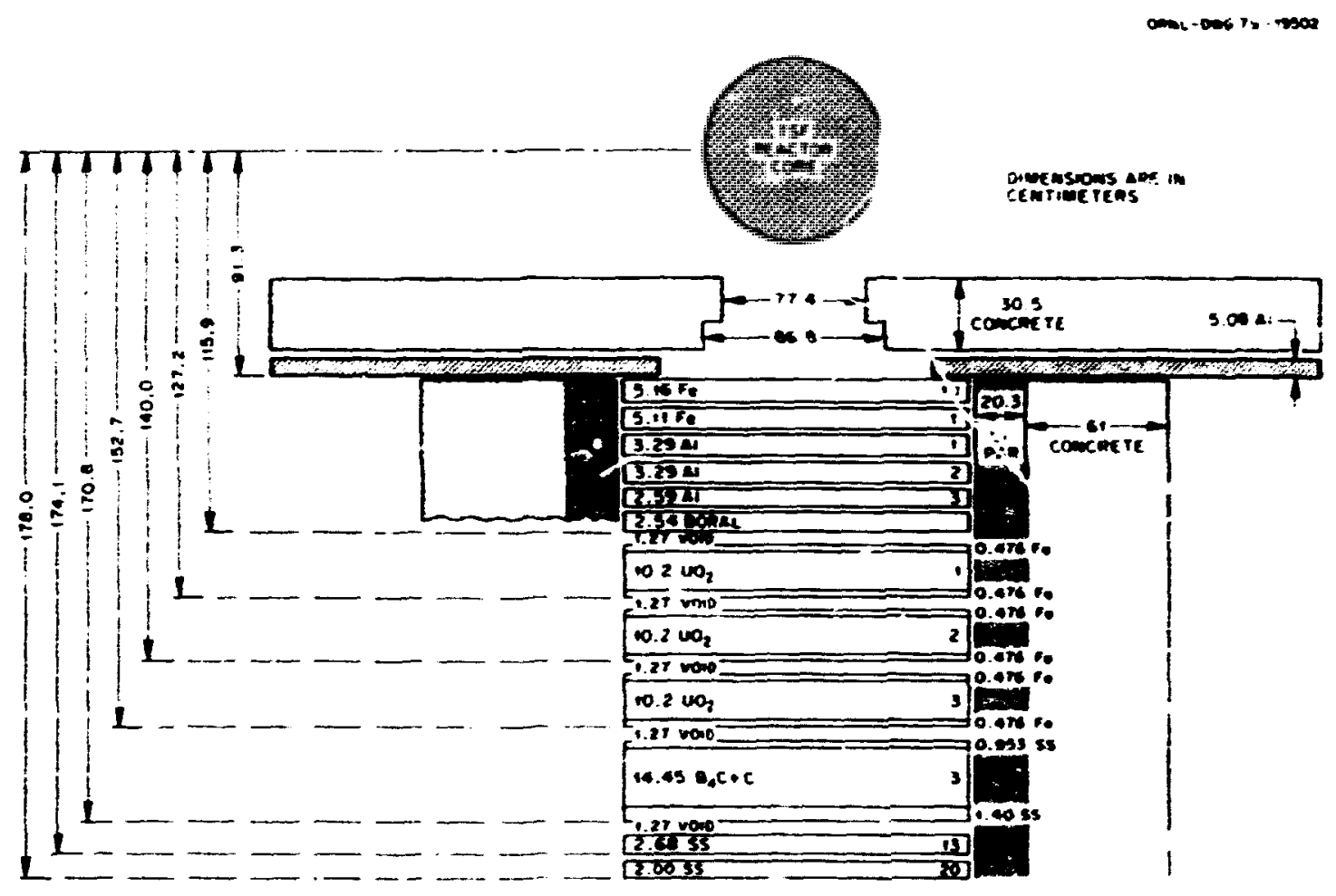

Fig. 8.11. Spectrum Modifler, UO, Radlal Blankei, and Final Phase of Alterrate Inner Radial Shield (Conf Iguration V.EF.

Configuration V.A was actual ily a repeat of : enf Iguration 11. A to ensure the repeatabillty of the source term. Configuration V.B consisted of Configuration V.A plus $15.2 \mathrm{~cm}$ of graphite, and Conf Iguration V.C consisted uf Conflgur ation V.B plus the 14.45-cm-thlck B,C-graphlte slab and $4.68 \mathrm{co}$ of stalnless steel. For Conflguration Y.O $15.6 \mathrm{~cm}$ of stainless steel was Inserted ahead of the 4.68-am Hickness. Finaliy, for Configuration V.E bcth the $15.6 \mathrm{~cm}$ of stainless steel and the $15.2 \mathrm{col}$ or graphite vere renoved.

Bonner ball moesurments $\left(3-, 6-\right.$, and $\left.10-1 n_{\text {. }}\right)$ wre mede beyond each of the alternate shleld conflgurations, noutron and gamerroy spectral measurcants were made beyond Conflgurations V.B and V.C, an? RD masurments were wade within volds in Conf igur atlons V.C, Y.D, and V.E.

The final serles of mesurenents in the experlment was added beceuse of offferences betweor. the mesured and the first calculated spectrd of noutrons beyond sever al conflgurations. The concern was that the calculated source term las dof ined for the 
TSA-II been or as calculated to bu enorging from the spectru nodiflerl wes In error. What was needed was a direct mesureant of the TSA-II bee spectrun, but this ves not possible since the residual gameray flux would love satur oted tha spectrometer. Merefore, wesurements of the bee were eade $v$. Th the ME-213 spectrameter shlel dod in one case by lead and In another by $\mathrm{Va}_{2}$. In addition, nasu swonts were wade with the spectru codifler in position behind the laad and $\mathrm{LO}_{2}$.

The detalled results of af I the easurements abo dur ing the exper Inent are presented in ref. 7. In this refort selected noesurements are compered with the corresponding celculated responses in Section 8.4 bela.

\subsection{PREMULYSIS ND EXPERIIETTN DESIGH}

The experiment cescribed in Section 8.2 was des: ned on the basis of a detalled proandysis that consisted of ono-dimenslenal (NWISW) transport calculations for trial exper Imental conf lgur atlons nocking up the GCFR blenket and radial shlelds. The prealialysis Included calculaticns of the sensitivitles of the TSF detector responses to partleular nucleer reactions elthln'the conflgurations, and also calcuiations of contrlbuton fluxes (1.e.. the fluxes of neutrons or gana rays within the conflguration thist reach the detectors).

The preanalysls actually began with $P_{3} S_{8}$ MISM transport calculations for the GOR Conceptuai Shlelding Configuration I (CSC.I) In order to galn same Insight into what the exper iantal conf Igur ations should represent. For these calculations CSC.I ras modeled In ono-dimensional Cylindrlcal $(R, \theta)$ genmetry using the ater lal compositions and Hilcknesses speclifed for the design et the core widplane. The modal covered the reglon from thit cxe vertical axis to epproxinately $30 \mathrm{co}$ Into the PCRV. The source was a distr lbuted flssion source calculated by Goweral Atonilc, and the crnes sectlons used were

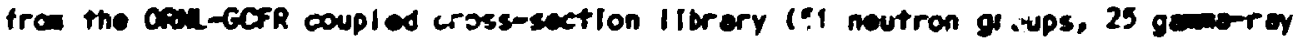
grcupsl. The calculated results were given as noutron and ganmeray-spectre at hey locstions In the system, and 't wos these spectra that were to be reproduced in the sxper imentel conf lgur atlons.

On of the spectrs to be reproduced wes, of course. the spectrun c! neutrone lenking

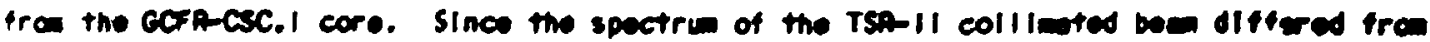


the CSC.I spectrue. the first celculations for the experimental design consisted of onediwensional transport calculations In slab ganetry to deternine hou varlous trial acterials woulc notify the TSA-II : oce. It was found that the spectru nodifler shom in FIg. 8.2 gave a leakege spectron that essentialiy wotched the spectron of neutrons fro the aSC.I ocre in the sigh-energy reglon (see FIg. 8.12), which wes the Ieportant reglon.

Next, transport calculations wre perforned for experimental conf Igurations consisting of the spectrin nodifler plus materlals mocking up the radlel blanket. It was orlginally Intended that In addition to making moesuremonts for the $\mathrm{ThO}_{2}$ blanket specifled In CSC.I, this phese of the experient would Include a dupl Icate se* of nessurements for a $\mathrm{UO}_{2}$ blanket. Merefore, the preanalysis was to Include calculations fo noth types of olankets. However, when attempts were mode to lacate the $\mathrm{WO}_{2}$ for the expe-Iment. It was found that an Insufficlent anount of "clean" $\mathrm{WO}_{2}$ was avallable. Im, was obtalnable tron the Sovannan River Project, but transport calculations shored that vater and altrate contal inants In the $\mathrm{LO}_{3}$ would produce an undesired : eakage spectrun.

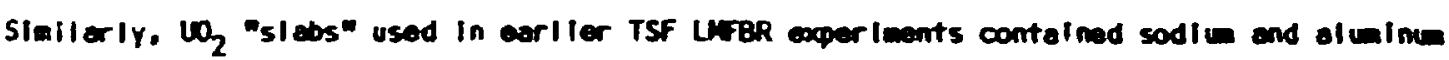
that would produce a deep dip in the energy spectron over a broed sodlu resonance. It was therefore decided not to perform a ramplete set of $\mathrm{LO}_{2}$ neesurements and instead to Imilude few measurements with the LFBR slobs al ready on hand (see Section 8.2).

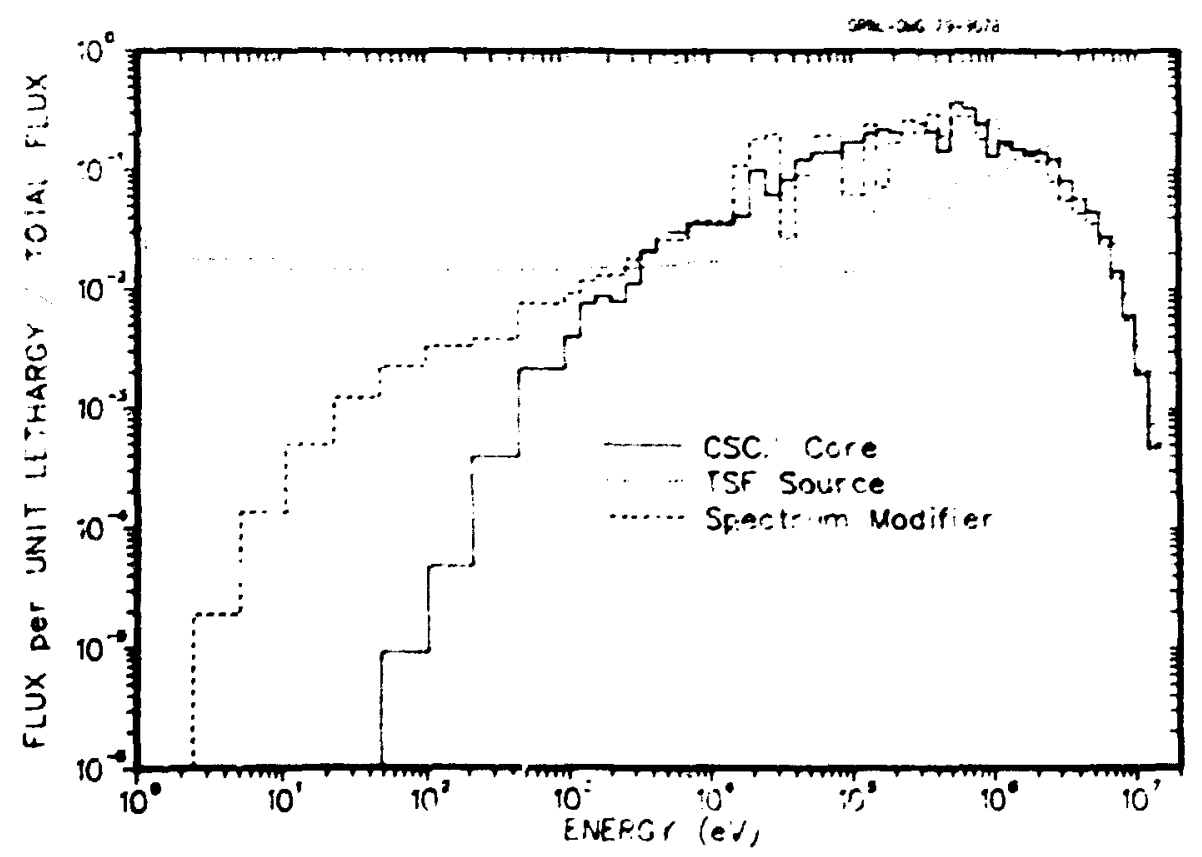

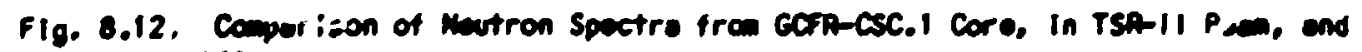
from Spection elodtler. 
An Important goal of the prearalysis was to ascertain whetner enalyies of the wesurements wade in the experiment would provide Inforwation on the nuclear reactions of jerticular Interest. ihls was determined by sensitivity enalyses, the results of wilch Indicated how much a given defector resporse would change vith a change In the density of a specific region of the conf iguration, thereby Indicating the Iepartance of nuclear reactions in the acterlal(s) of that region and Identifying the perticular types of reections that were Important. The sensitivity anal yses were performed with the Sunurike sensitivity code, wich uses fluxes calculated from both forwerd ans adjolat Mish colculations.

The one-dicenslonal models used for the sensitivity enalyses of the Bonner ball responses beyond the $\mathrm{LO}_{2}$ and $\mathrm{ThO}_{2}$ blenket conflgurations a shown In FIg. 6.13 (Sketches $A$ and $B$ ). The analysis shoved that the Bonner ball responses were very sensitive to changes in the densities In the Important nuclidas (uranlu and thorlui), whIch Indicated thet relicbie interpretation of the deta weult be possible in the final enalysis. On the other hand, the respunses ure also quite sensitlve to the oxygen Ir. the blanket reglons, which woant that the heary watals and the cuxygen both would have to be considered carefully in the final analysis of the experiment. The relative sensitivities to the heavy metals and axygen varled markedly with the size of the Bonner bal I, however, and the differences between the Bonner ball responses were expectod to facllitate Identification of the Interections contributing to any discrepencles thet alght occur betwen neasured and calculated values.

In the sensitivity calculations for no responses in the blanket conf Igurations, It was assund that the detector was positioned betwean the last two blanket slabs shown in Sxetches A and B of FIg. 8.13. (Note: The model actual ly eployed for the no calculations Includad $10.1 \mathrm{~cm}$ of $\mathrm{LO}_{2}$ In the spectrun modifler Instead of the $9 \mathrm{Ca}$ of al Einim.) In contrest to the Bonner belis, the sensitivities of the RL were not exceptiond'ly lerge, but they appeared to be adequets for ralleble interpretetion of the results.

An Importent result of the Ro celculatlons wes the dlscovery thet 218 of the reye detected II the $\mathrm{mnO}_{2}$ configuration and 335 of those detected in the $\mathrm{VO}_{2}$ conflguration were eccondery geme reys prosucad in the steal on sech side of the 

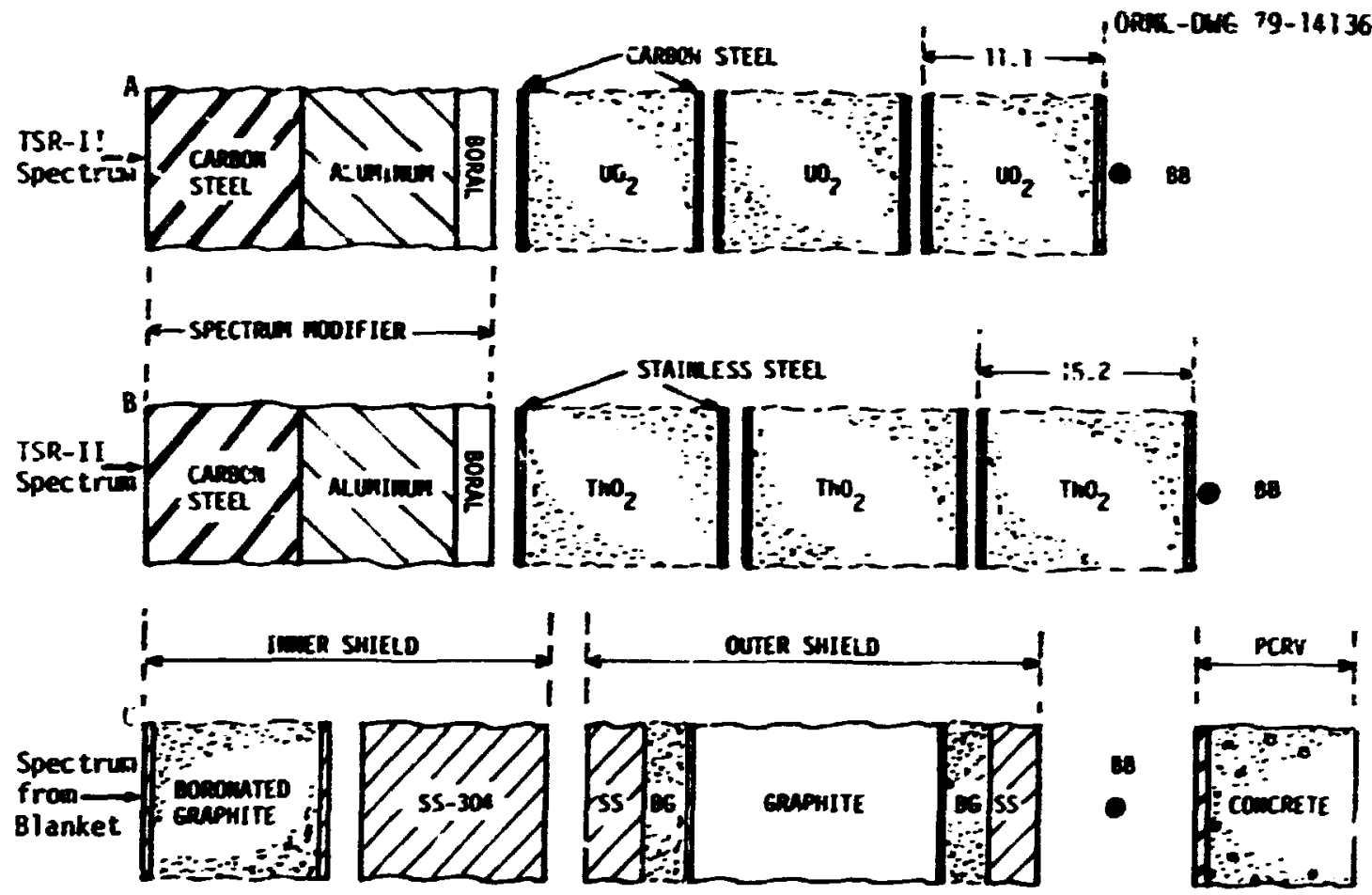

Fig. 8.13. One-Dimensional Vodels Used for Preenalysis. The slab calculations had a boundery source at the left boundery and a vold on the right boundary.

detector. The realining garma rays were produced in the thorlu and uranlus, with the region behind the RD contributing epproximately as wuch to the response as the region preceding the Ro. It was also noted thet game rays born II locations farther then 25 ca fran the RD did nct contribute to the response. So ther RD masurements could be made in which a higher percentege of the jotected gand roys would be coming fram the blanket materlals, one of the $\mathrm{ThO}_{2}$ blanket rows we; fobrlated as ho half-rows, each with thinner stainiess steel walls. The Tho could then be positioned with less steel on either side.

Following the studles of the blenket conflgurations, calculations wore parformed for the inner and outer radial shlelds, using the model show In Sketch C of FIg. 8.13. These celculations Included sonsitivity calculations for a Bonner bal I positioned in the vold botwen the outer shleld and the PCeN. Ageln the Bonner ball censitivities were found to we lerge (eapecial ly for the stalniess steol and the orephite) and the verlotion In the reletive sensitivitles botweon the three Bonner balls ves epperent. 
Calcuiations were also performed tor a fletitlous total gene-ray defector located betwea the outer shield and the PCXI. Of ibe ganes rays reaching the defector, neerly T5 we produced es secondary gan rays in the stainless steel cleddings on the shletd slads and noerly $10 ;$ in the PCeN certon sted lining. The only other significant contribution was from the boron In the shlelds (13.6\%). Essentialiy no "source" ganme rops (those entering fra the blenket) wre detectes.

Finally. cxatributon f!uxes were calculated for the Bonner bal is and the fictitious

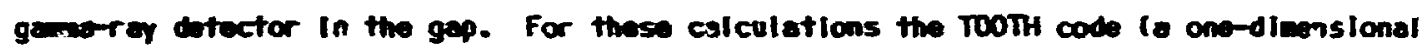
equivalent to the Fins codel wes uritten for the purpose of calculating the contributon fluces as a function of both spoce and energy and plotting the results on a threedinansional surfece. For the Bonner sal is the results Indlcated the rel atl ve aghitudes and energles of the neutron fluxes if the various shleld reglons that would contribute to the Bonner bel I responses. Figure B.14 shous, for exanle, that of the neutrons passing through the inner shleld, okty those witi. high energles will reach the Bonner bolls in the gap. Horever, becouse the 3-in. Eunner ball largely detects Iom-energy noutrons ond the 10-In. ball largely detects high-energy neutrons, the two balls will "see" cliferent neutrons tra the outer shleld. Also, the 3-In. ball will detect neutrons scattered beck iran the PCR concrete.

The Interpretetion of the contributon fluxes for the gamerer detector is nore complicated since it is meutron interections that produce the detected gana rays. Thus both noutron fluxes and gampray fluxes must bo consliared and Interrelated. Such on Interrelationship Is shown In FIg. 8.15. The top sketch shows the wagnitudes and energles of the mutron fluxes thet will produce the geme rays reechling the detector and also shows the shield regions in which those interections will take plece. The lower sketch shows the megoitudes and enorgles of the resulting gammer roy fluxes and ol so the shield regions in whish the gome reys ere produced.

The dominent peck of the neutron flux (In the Inner shleld region) probebly ropresents neutron Inelestic scetterings in the steel wile the lower peaks eround it are probebly dwe to the capture of Internmediate-enorgy noutrons In the steel. The lom-energy peaks on elther side of the detector ere due to lomenergy neutron ceptures in the outer shleld grophlte and the conerete of the PCAV. 


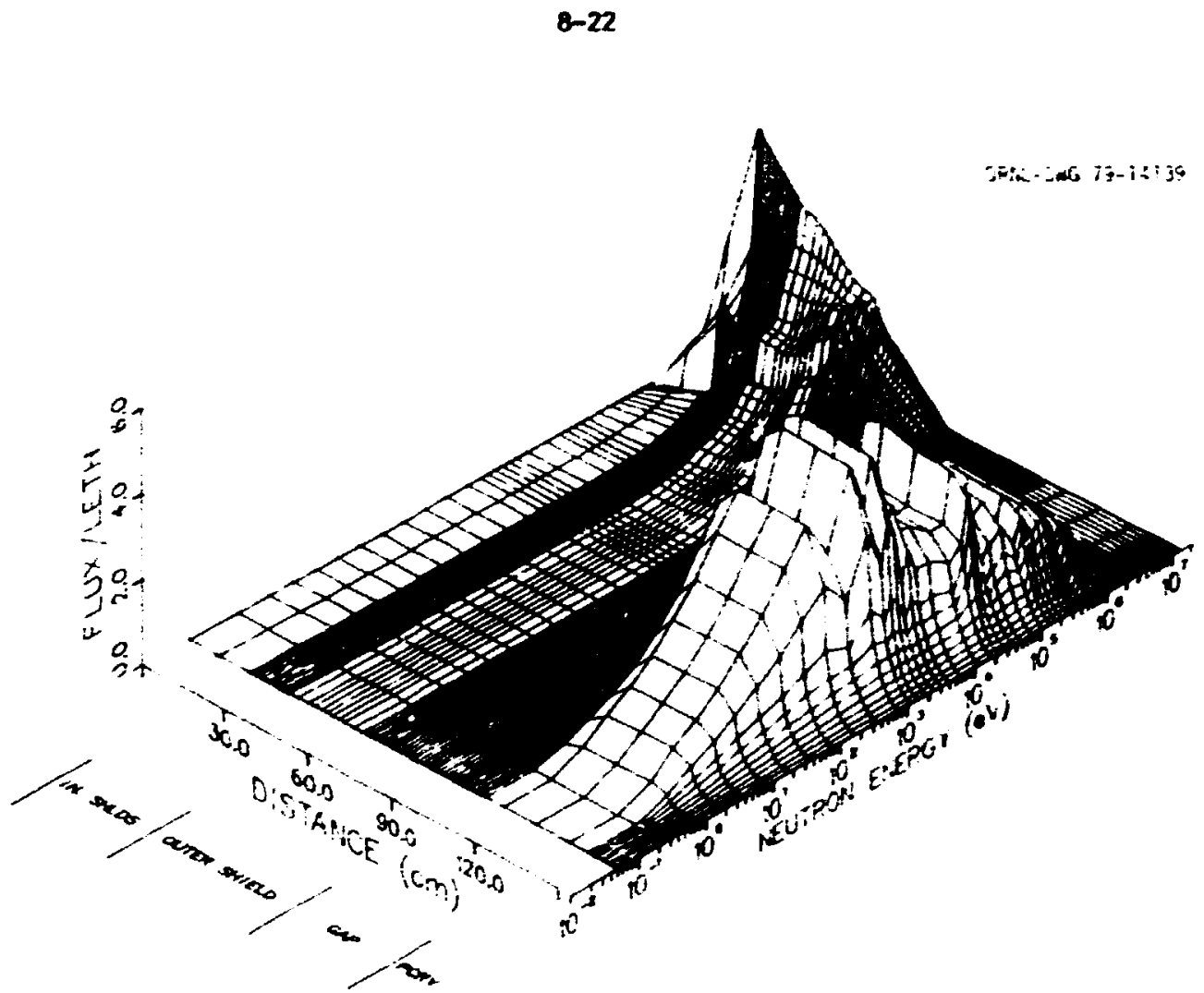

(a) 3-in. Bonner Gall.

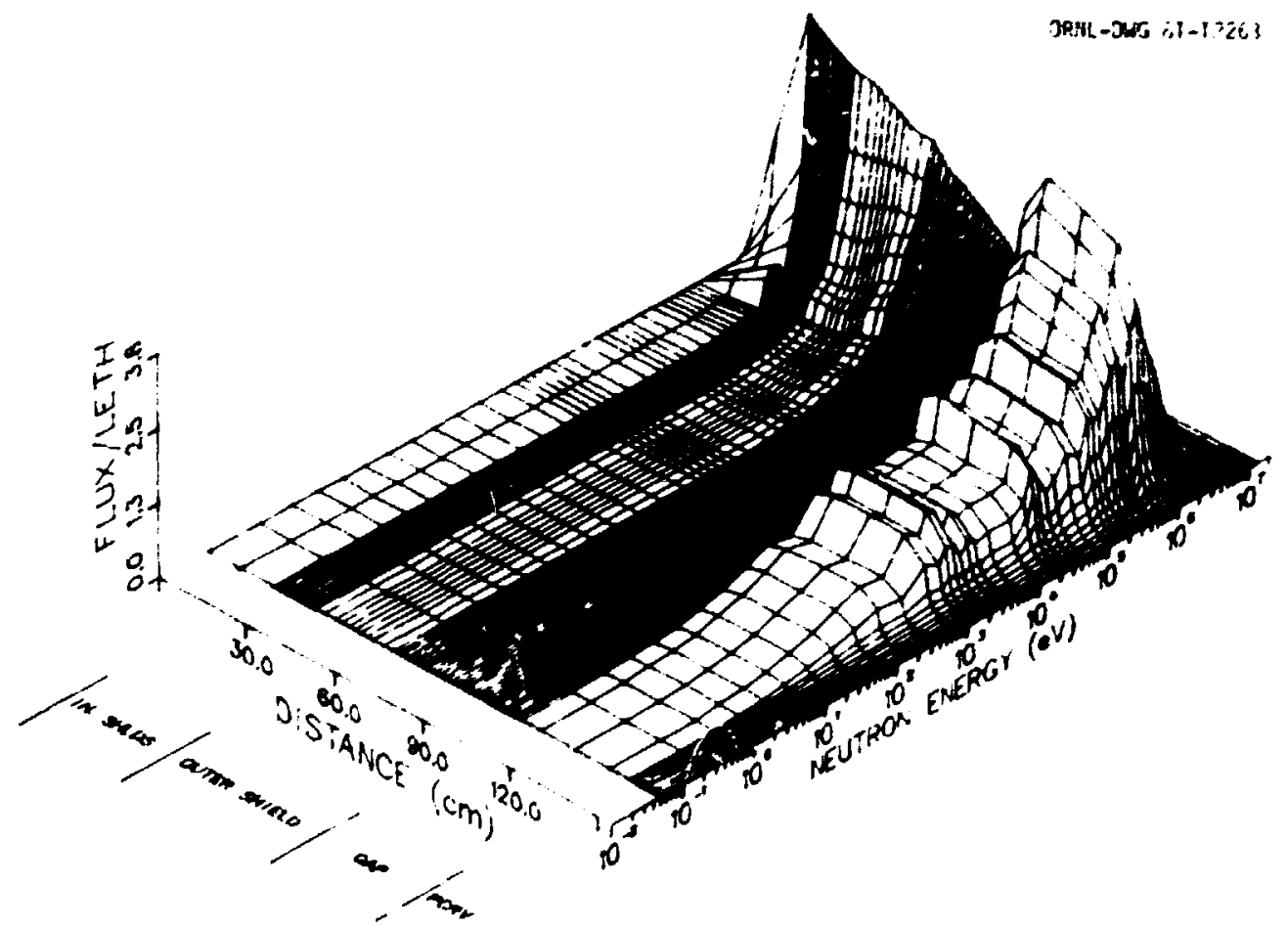

(b) 10-in. Bonner Ball.

Fig. B.14. Noutron Contributon Fluxes for Bonner Bal is Loceted in Gop Botweon Outer Shield and PCRV. 

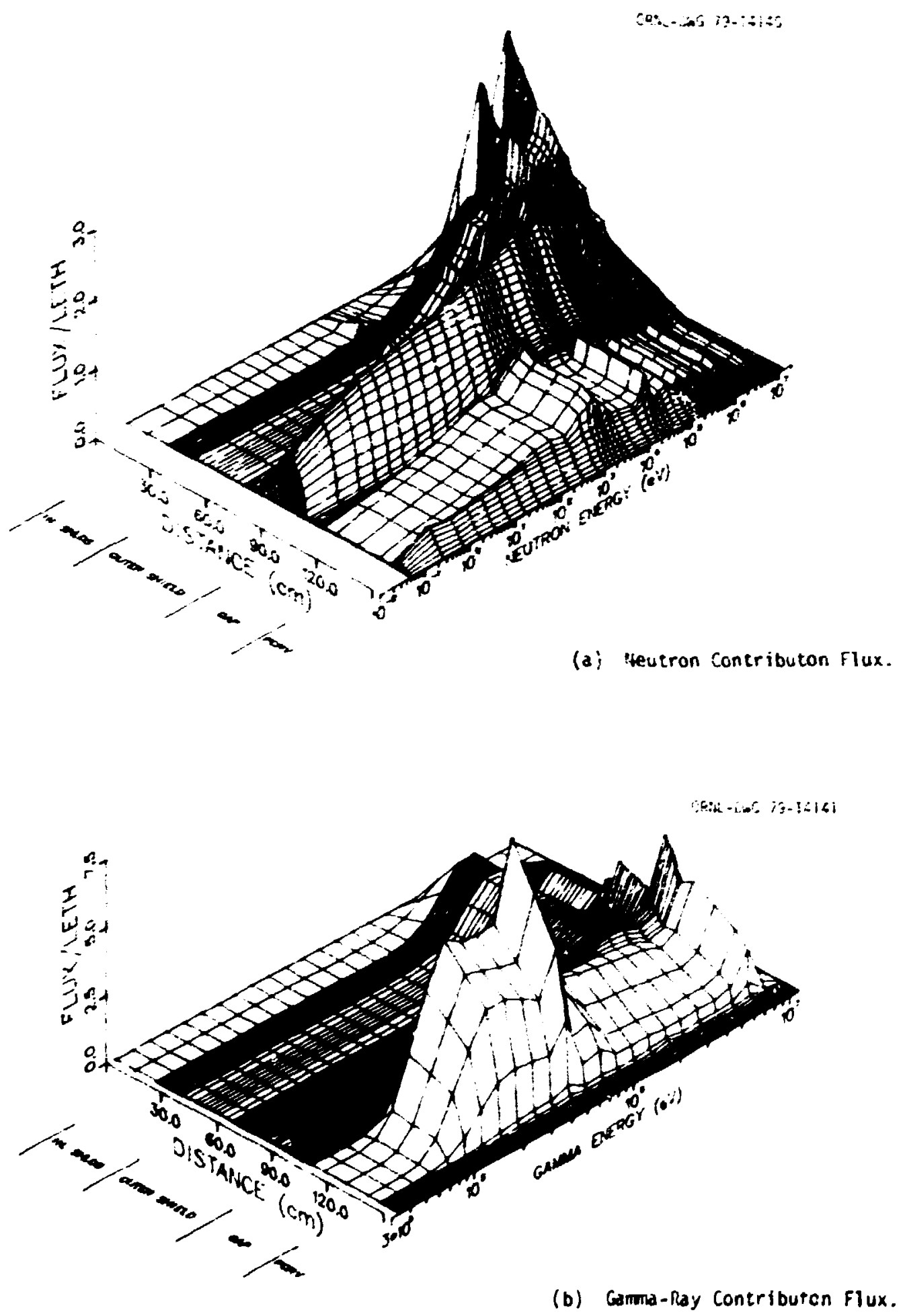

Flg. 8.15. Contributon Fluxes for Fictitlous Total Gama-Ray Detector in Gap Botrueon Outer Shield and PCRV. 


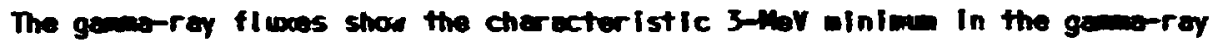
Interaction cross section as a ridge through the shield. The 7- to 8-ther gane rays produced by neutron capture in the steal and 0.511 -mal annihllation gane rays are a! so apparent.

In addition to the ebove, the rreanalysis Includad transport calculations to resolve two problems that arose during the febrication of camponts to be used in the exper iment. The first one was essoclated with a difficulty in attaining the desired packed density of the B,C + graphite pouder to be used in same of tile shield slabs. When the dimensions for the shleld reglons of the experimantal conf lguration were set, it had been essuned that the density of $1.6 \mathrm{~g} / \mathrm{cc}$ called for in the CSC.1 design could be achleved, and therefore the stainless steel cans febricated to hold the pouder vere speclfled to have the same thicknesses as the corresponding CSC.I reglons. However, when the vendor attempted to fill the contalners, the highest bulk density attalnable was 1.0 g/cc. Transport calculations were performed to deternine the effect of the reduced density, and It was found that the shepe of the neutron leakage spectra from the regior would be the same for both densitles. It was therefore declided to use the cans with the lower density and to correct for the difference in the magnltude of the flux. As it turned out, however, Oan experts Instristed the vendor in the ert of ho-perticle vibration packing, and a bulk tensity of $1.4 \mathrm{~g} / \mathrm{cc}$ was eventually achlerid.

The second problem had to do with a high natural background activity in the $\mathrm{ThO}_{2}$ acquired for the experiments. A measured activity of $50 \mathrm{mR/h}$ at the surfece of the slabs procluded positioning the gemersy spectrameter close behind the slabs, whlle other beckground problens discouraged moving the spectraneter back. One alternative was to fllter the beckground radjation through lead or Iron. Since the Iron cross sections were better known than the leas cross sections, and thus would introduce less uncertainty in the flinal analysls of the experiment, transport celculations were performad to deternine the of fect on the leakage spectro of using en Iron filter. The results showed that the neutron spectrum suffered adverse offects and the gamanory spoctrum vas converted fran a $\mathrm{ThO}_{2}$ leakage spectrum to an Iron leakege spectrim, whIch vas unaccepteble. The final solution was to move the spectrometer beck and to protect it fram other beckground offects by surrounding it with concrete housing containing collimator. 


\subsection{POSTMULYSIS OF THE DOPERIKET; COMPARISON OF} CHCOLATED MD IEASTRED RESULTS

Table 8.2 Ils:s a total of 24 experimental conf Igurations. Of these, 12 representative conf Igurations vere selected for fInal analysis, with wost of the anelysis effort consisting of the usual tro-dimensional DOT calculations of radiation transport through the configurations mocked up in R-Z cylindrical goometry. For the InItIal calculations an external boundary angular flux describling the TSA-II source vas Incldent on one end of the cylinder, but as the configurations becane larger and nore capll lcated (Including rissions In the blanket regions as vel I as transport), internal boundery sources mre saved for use as external sources In subsequent calculations. All the DOT calculations used an $S_{10}$ symatric angular quedrature (70 angles), fogether with the CCFR 51 -group neution cross sections coupled with 25-group gameray cross sections. The FNSTF code was used to determine the fluxes at detector locations beyond the conf I gurations.

In addition to the DOT-FNSTF sequence, a serles of MISN calculations In onedimensional slab gecmetry were performed to compere different cross-section data. In particular, the calculations exalned the effect of substituting into the calculations the ENDF/B-V date for thorlum, which were not released until after the GCFR cross-section set had been In use for same time.

\subsubsection{Definition of Source}

As In the analyses for the earller experiments, the TSR-II large col IImated bea used as the source In the experiment was converted to the disk boundery source required for the tro-dimenslonal calculations (see Section 7.4.1 and Fig. 5.3). A 00T calculation was performed that Included the disk source ond the spectrum modifler (sen FIg. 8.16), and the resulting internal boundery source at the inner surface of the spectrum modifler was then used as the Initial external boundary source for the analysis.

\subsubsection{Transport Calculations for Spectrun Modifler}

The first transport calculations performed in the analysis of the radial shleld conf imation experiment were for the spectrum modifler conflguration shown in Fig. B.2 


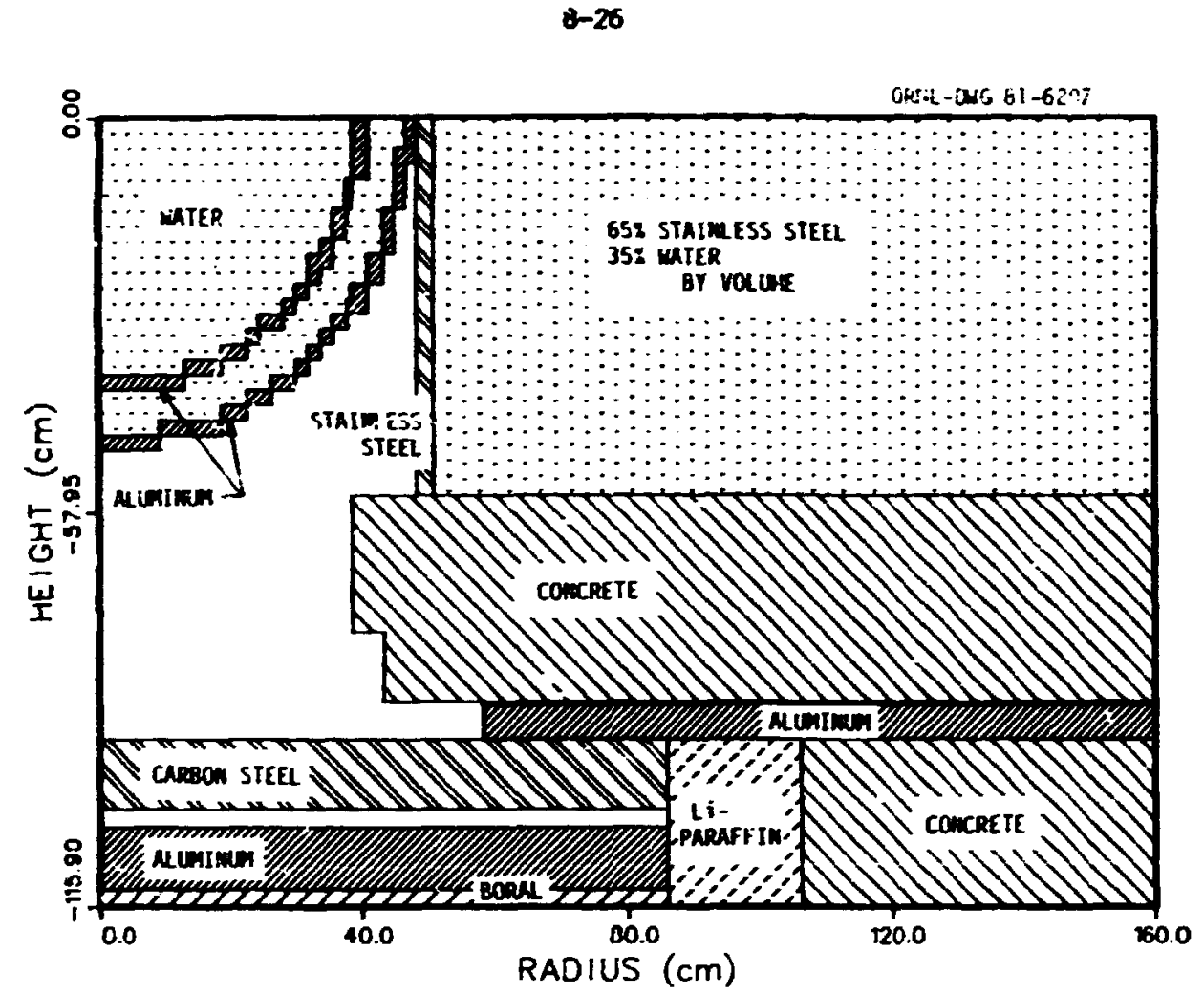

Fig. 8.16. Two-Dimenslonal R-Z Model of TSR-II, Bean Collimator and Spectrum Modlfier (Conf Igur otI on I.A).

(Configuration I.A). Since this configuration was sufflclently thin for neutrons from the TSR-II beas to pass through It without undergoing a collision, calculations of the uncollided fluxes had to be performad separately, by FALSTF, and added to the DOT-FASTF collided fluxes determined for each detector polnt. The total flux at each polnt was then converted to Bonner ball responses. The resulting ratlos of the calculated and measured responses for 3-, 6-, and 10-In. Bonner balls are shown for three on-axls locations behind the spectrum nodifler In Table 8.3.

Tahle 8.3. Colculated-to-Measured Bonner Ball Responses Beyond Spectrum ModI +Ier (ConfIguration I.A)

\begin{tabular}{|c|c|c|c|c|c|c|c|}
\hline \multirow{2}{*}{$\begin{array}{l}\text { Oistance } \\
\text { (cm) }\end{array}$} & \multicolumn{3}{|c|}{$\begin{array}{l}\text { Moosured Responso } \\
\text { (counts/min ati) }\end{array}$} & \multicolumn{3}{|c|}{ Colc./Moss. } & \multirow{2}{*}{$\begin{array}{l}\text { Mothod used for } \\
\text { Uncol I lided Fl ux }\end{array}$} \\
\hline & $3-\ln .88$ & $6-1 n .88$ & $10-\ln .88$ & $3-1 \pi .8 B$ & $6-\ln .88$ & $10-\ln .88$ & \\
\hline $\begin{array}{r}30.5 \\
304.8 \\
396.9 \\
396.9 \\
390.9\end{array}$ & $\begin{array}{l}1.25(5)^{b} \\
3.95(3) \\
3.40(3) \\
3.40(3) \\
3.40(3)\end{array}$ & $\begin{array}{l}8.22(5) \\
3.89(4) \\
2.32(4) \\
2.32(4) \\
2.32(4)\end{array}$ & $\begin{array}{l}3.92(5) \\
1.78(4) \\
1.08(4) \\
1.08(4) \\
1.08(1)\end{array}$ & $\begin{array}{l}1.06 \\
0.94 \\
1.00 \\
1.06 \\
1.02\end{array}$ & $\begin{array}{l}1.07 \\
0.93 \\
0.95 \\
1.04 \\
0.99\end{array}$ & $\begin{array}{l}1.01 \\
0.03 \\
0.93 \\
1.07 \\
1.01\end{array}$ & $\begin{array}{l}\text { FALSTF } \\
\text { FALSTF } \\
\text { FALSTF } \\
\text { Polnt TSA-I I Source } \\
\text { Sholl TSA-II Source }\end{array}$ \\
\hline
\end{tabular}

All collided fluxes calculated by DOT-FALSTF.

Bead; $1.25 \times 10^{5}$. 
The underprediction of the total and high-energy neutron fluces at the distant

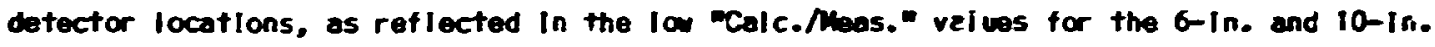
Bonner balis respectively (IInes 2 and 3 In Table 8.3), was attriburted to the angular quadrature used by FRSTF being too coarse; therefore, two alternete epproeches were al so used to calculate the uncol Ilded fluxes at these locations. In the first alternate approach the TSR-II wes appraximated as a polnt source and the uncollided flux was calculated iron the simple relation:

$$
\phi_{u}=\left(S / \operatorname{sun}^{2}\right) \exp \left[-\left(\Sigma_{T} x\right)_{F_{\theta}}-\left(\Sigma_{T} x\right)_{A !}-\left(\Sigma_{T} x\right)_{B \text { orat }}\right]
$$

where $\phi_{v}$ is the uncollided $f I u x, S$ is the TSR-II source strength, $R$ is the cistance from the TSR-1I to the detector, $\Sigma_{T}$ is the total macroscoplc cross section, and $X$ is the slab thickness. The second approach used the same relation but treatec the reactor source as a shell sourcs which requiled Integration over the surfece of the reactor. This second technlque yielded the best results as shoun by a coaparison of the entrles in the last two I ines of Table 8.3 .

The same three technlques vere appl led to the calculation of the neutron energy spectra for comparison with measirements made at the 396.9-am location with the NE-213 spectrometer $(800 \mathrm{keV}$ to $15 \mathrm{MeV})$ and the hydrogen counter $(50 \mathrm{keV}$ to $1 \mathrm{MeV})$. The results are shown In FIg. 8.17. Agaln the shell source approach (labelled "sphere" In the figure) oppears to glve the best overall results.

\subsubsection{Transport Calculations for Blanket Configuretions}

As polnted out in Section 8.2, blanket conflguratlons using both $\mathrm{ThO}_{2}$ and $\mathrm{WO}_{2}$ vere measured. Emphesls was placed on the $\mathrm{ThO}_{2}$ measurements because of the partlculer Interest in "alternate" fuel cycles and because the uncertalnties assen Iated with the cross sectlons were larger for thorlum than for uranlus. Also, as explained earller. "clean" $\mathrm{CO}_{2}$ slabs vere not avallabl for the exper Iment.

Calculated-tommasured ratlos of Bonner ball rosponses beyond two of the $\mathrm{ThO}_{2}$ blanket conflgurations and one $\mathrm{U}_{2}$ conflguration are shown in Table 8.4. In general, the calculations underpredlct the responses for the $\mathrm{UO}_{2}$ conflguration (II.A), perticularly at 


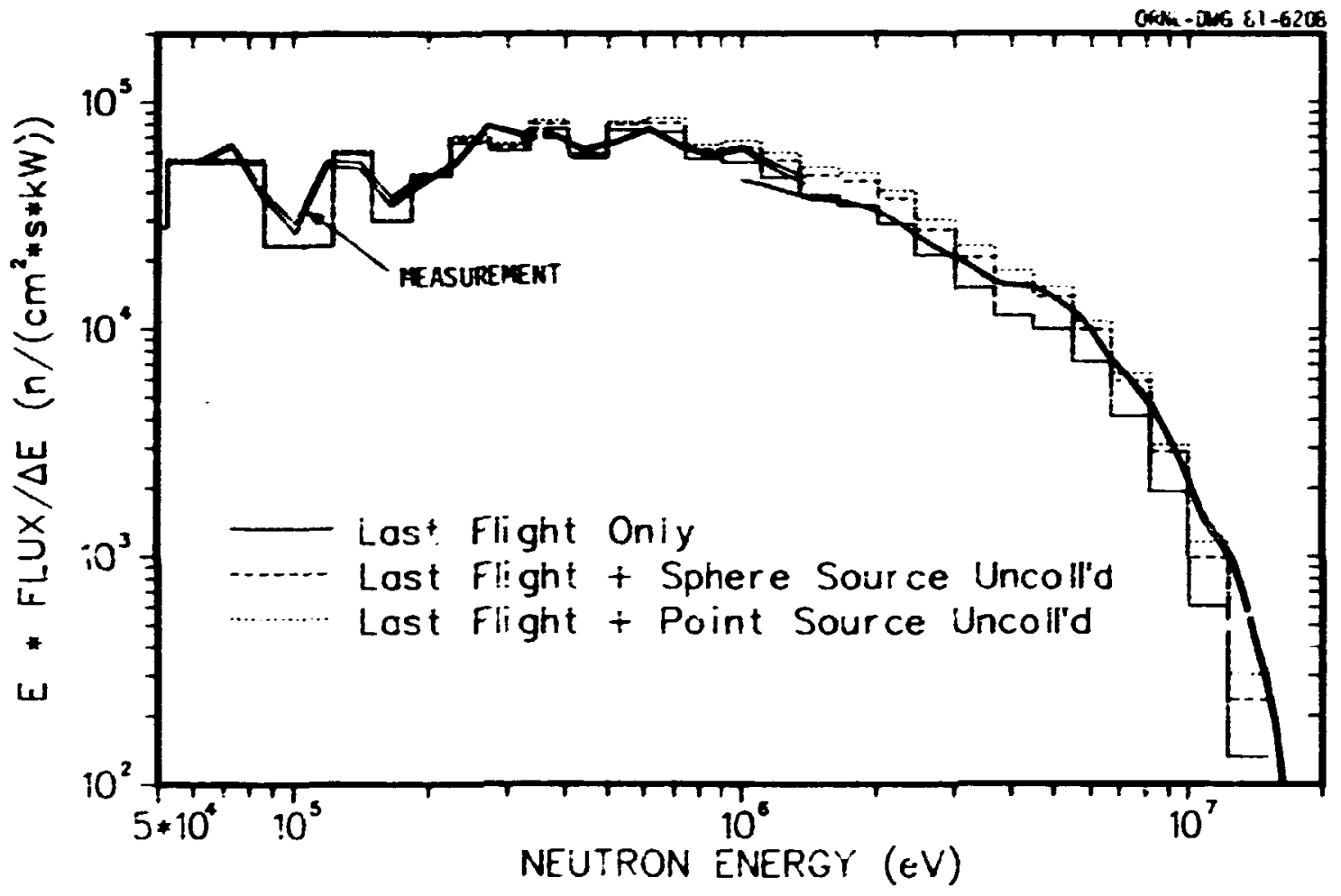

Fig. 8.17. Cumparison of Calculated and Measured Meutron Spectra 396.9 ca Benind Spectrin Modifier (Corfiguration I.A).

Table 8.4. Calcul oted-to-moasured Bonner Bal: Responses Beyond Blanket Conf igurations

\begin{tabular}{|c|c|c|c|c|c|c|c|}
\hline \multirow[b]{2}{*}{ Conilguration } & \multirow{2}{*}{$\begin{array}{l}\text { Distance } \\
\text { (co) }\end{array}$} & \multicolumn{3}{|c|}{$\begin{array}{l}\text { Mosured Responso } \\
\text { (counts/min-W) }\end{array}$} & \multicolumn{3}{|c|}{ Colc./mas. } \\
\hline & & $3-\ln .88$ & $6-\ln .8$ & $10-1 n .88$ & $3-1 n .8 B$ & $6-1 n .88$ & $10-\ln .88$ \\
\hline $11 . A\left(\cdot 30 \mathrm{ag} \mathrm{w}_{2}\right)$ & $\begin{array}{r}30.5 \\
205.4 \\
304.8\end{array}$ & $\begin{array}{l}1.50: 4)^{\circ} \\
8.06(2) \\
7.15(2)\end{array}$ & $\begin{array}{l}7.44(4) \\
3.60(3) \\
3.21(3)\end{array}$ & $\begin{array}{l}2.44(4) \\
1.23(3) \\
1.09(3)\end{array}$ & $\begin{array}{l}0.98 \\
0.88 \\
0.88\end{array}$ & $\begin{array}{l}0.91 \\
0.86 \\
0.84\end{array}$ & $\begin{array}{l}0.83 \\
0.77 \\
0.77\end{array}$ \\
\hline $1.0\left(.30 \mathrm{~cm} \mathrm{TnO}_{2}\right)$ & $\begin{array}{r}30.5 \\
304.8 \\
1314.1\end{array}$ & $\begin{array}{l}1.42(4) \\
5.94(2) \\
2.74(1)\end{array}$ & $\begin{array}{l}7.20(4) \\
2.26(5) \\
1.37(2)\end{array}$ & $\begin{array}{l}2.53(1) \\
9.90121 \\
4.90(11)\end{array}$ & $\begin{array}{l}0.99 \\
1.03 \\
1.28\end{array}$ & $\begin{array}{l}0.95 \\
1.05 \\
1.26\end{array}$ & $\begin{array}{l}0.91 \\
0.96 \\
1.12\end{array}$ \\
\hline I.E ( $\left.-45 \mathrm{~cm} \mathrm{ThO}_{2}\right)$ & $\begin{array}{r}30.5 \\
304.8 \\
12 \% 6.4\end{array}$ & $\begin{array}{l}3.78(s) \\
1.69(2) \\
7.83(0)\end{array}$ & $\begin{array}{l}1.62(4) \\
6.83(2) \\
3.21(1)\end{array}$ & $\begin{array}{l}4.04(3) \\
2.48(2) \\
1.00(1)\end{array}$ & $\begin{array}{l}1.02 \\
1.01 \\
1.27\end{array}$ & $\begin{array}{l}1.03 \\
1.09 \\
1.36\end{array}$ & $\begin{array}{l}0.99 \\
0.88 \\
1.20\end{array}$ \\
\hline
\end{tabular}

Road: $1.60 \times 10^{4}$. 
large distances and for high neutron energles (In the 10-in. Bonner ball ranga). By contrast, but with exceptions, the calculations overpredict the responses for the $\mathrm{ThO}_{2}$ conf Igurations (1.D and I.E), perticularly at large distances. However, in I ight of the conbined experimental and analytical uncertaintles, which range as high as 10, 15, and 201 for the 3-, 6-, and 10-in. balls, respectively, the agreenent Is considered to be guod in most cases.

Comparlsons of calculated and mesured neutron spectra at a distance of approximately $1300 \mathrm{co}$ beyond each of the conf Igurations also shomed relatively good egreament (see upper curves In FIgs. 8.180-c). In the case of the $\mathrm{IO}_{2}$ confIguration, the calculations underpredicted the spectru 20 to 305 beion $2 \mathrm{MeV}$, whlle In the cases of the $\mathrm{ThO}_{2}$ configurations the calculations overpredicted the spectrin somewhat, noreso for the thicker blanket.

Calculations of the gama-ray spectra beyond the bla'ket conf Igurations vere not iearly so successful. For the $\mathrm{UO}_{2}$ configuration (II.A) the calculated spectrum was Ior by about 503 at $1 \mathrm{MeV}$ and by as wuch as a factor of 5 at $7 \mathrm{MaV}$. For the $\mathrm{ThC}_{2}$ spectra the calculations and measurements are In falr agreement below 4 MeV, but the calculatlins severely underpred. cted the masurements above $4 \mathrm{Mbl}$. It Is to be remenbered, however, that the EDF/B-IV cross sectlons applled In these calculations did not Include thorlum gavmarroy production tota, and the ganimo-ray proouction cross sections used were estimated tram uranlum gama-ray production cross sections.

The Inadaquecy of the estimated gama-ray production cross sections is also apparently reflected in the calculated TLD heating rates for ConfIguration I.E (see Table 8.5). The large underprediction of the heating rate in the first vold in Conf Iguration 1.E (and also in Configuration $I I . A$ ) can, of course, be attrlbuted to the absence of a gamer ay component in the calculated TSA-II source. But the heating rates In the subsequent volds would be prlmerlly due to secondary geme rays and therefore would be determinad by the gammerey production cross sections. In the case of the $\mathrm{LO}_{2}$ configuration the calculated heating rates for Volds 2 and 3 are within the 7 to $10 \%$ uncertainties In the experiant, Indlcating that the ganuaray production and absorption cross extions for uraniun ore reasonable. But In the case or the $\mathrm{ThO}_{2}$ conflguration, lergo discrepencles eppar for Volds 2, 3, and 4, the calculations overpredicting the mosurcuments by 25 to 378 . 

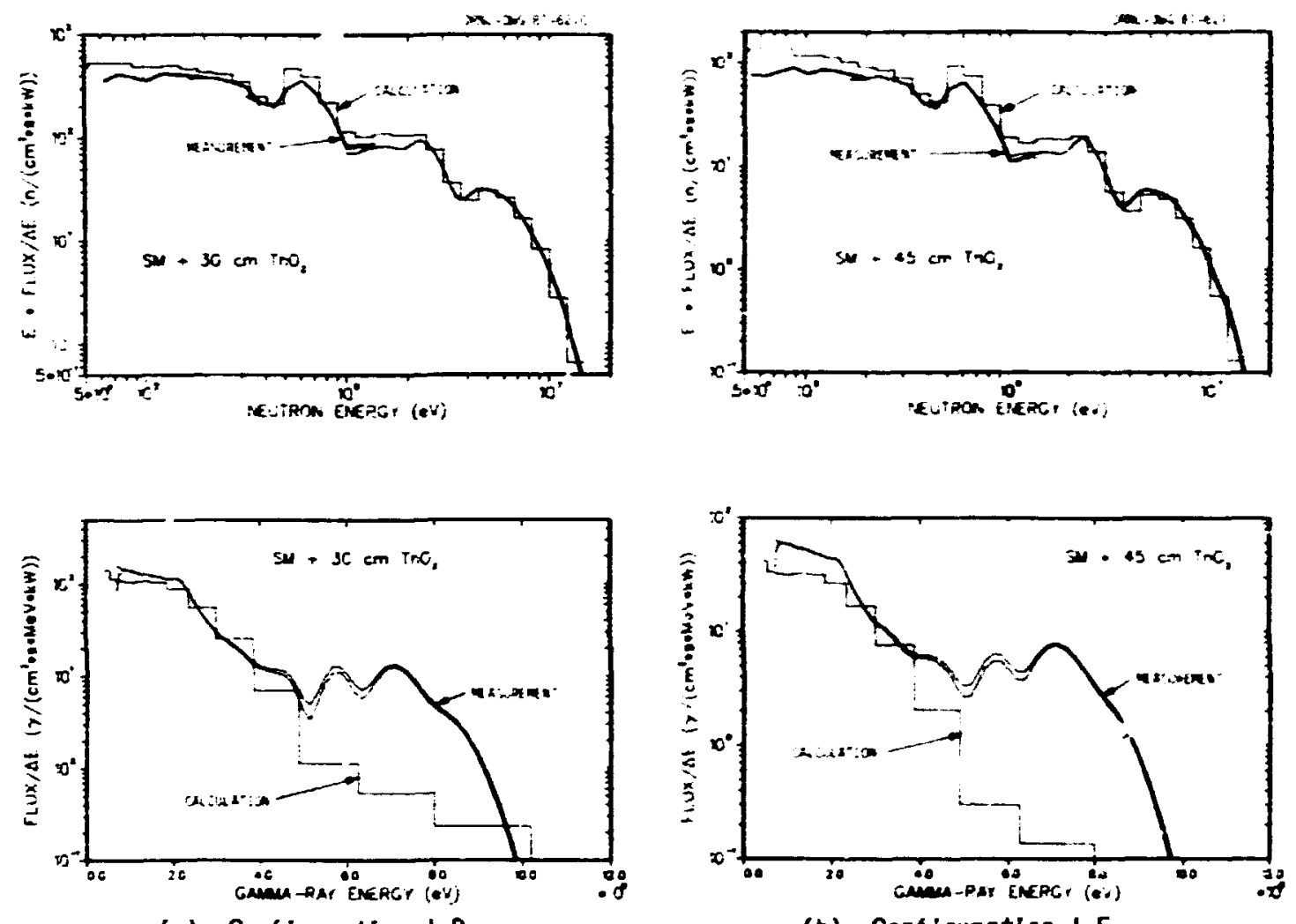

(a) Configuration 1.D.

(b) Contiguration I.E.

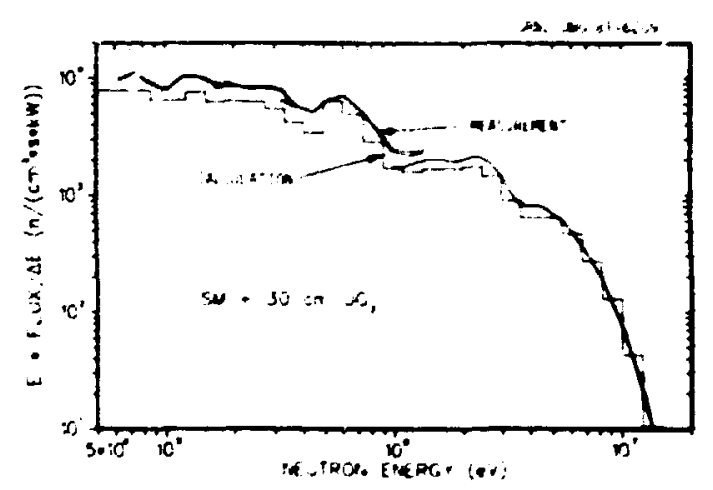

Fig. 8.18. Comparison of Colc.loted and Masured Meutron and Game-Roy Spectra $4300 \mathrm{~cm}$ Beyond Bl anket Conf lgur at lons.

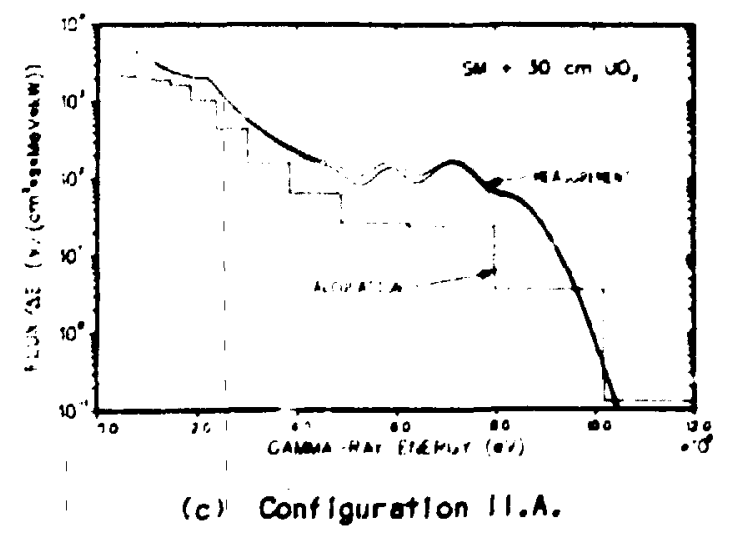


Table 8.5. Comparison of Calculated and Masured (IDD) Hating Rates in Blanket Configurations

\begin{tabular}{|c|c|c|c|c|c|c|}
\hline \multirow[b]{3}{*}{ Cont Iguration } & \multirow[b]{3}{*}{ Location } & \multicolumn{4}{|c|}{ Hating Rate (Hav/(g-sac-kw) } & \multirow[b]{3}{*}{ Calc./moos. } \\
\hline & & \multirow[b]{2}{*}{ Maa-ured } & \multicolumn{3}{|c|}{ Calculated } & \\
\hline & & & Gomas & Neutrons & Total & \\
\hline $11 . \mathrm{A}^{\circ}$ & $\begin{array}{l}\text { Yold } 1^{b} \\
\text { Yold } 2 \\
\text { Vold } 3\end{array}$ & $\begin{array}{l}9.60(5)^{c} \\
1.26(5) \\
4.52(4)\end{array}$ & $\begin{array}{l}5.05(5) \\
1.02(5) \\
4.17(4)\end{array}$ & $\begin{array}{l}4.48(4) \\
1.59(4) \\
5.38(3)\end{array}$ & $\begin{array}{l}5.50(5) \\
1.18(5) \\
4.71(4)\end{array}$ & $\begin{array}{l}0.57 \\
0.93 \\
1.04\end{array}$ \\
\hline $1 . E^{0}$ & $\begin{array}{l}\text { Yold } 1^{b} \\
\text { Vold } 2 \\
\text { Yold } 3 \\
\text { Yold } 4\end{array}$ & $\begin{array}{l}9.72(5) \\
7.77(4) \\
4.00(4) \\
1.88(4)\end{array}$ & $\begin{array}{l}5.00(5) \\
8.92(4) \\
5.08(4) \\
2.37(4)\end{array}$ & $\begin{array}{l}4.10(1) \\
0.25(3) \\
3.80(7) \\
1.61(3)\end{array}$ & $\begin{array}{l}5.41(5) \\
9.75(4) \\
5.46(4) \\
2.53(4)\end{array}$ & $\begin{array}{l}0.56 \\
1.25 \\
1.37 \\
1.34\end{array}$ \\
\hline
\end{tabular}

¿sea Fig. 8.5 .

birst vold following spoctru nodifler.

Cread: $9.60 \times 10^{5}$.

¿seo 5ig. 8.4.

By the time this analysis was being perforned, EDF/B-V thor lin cross sectlons thet Included gamarray production data had been released. In order to gain same Insight as to what effect the new cross sections would have on the calculated results for the blanket conflguratlons, a technlque was devised for Introducling the Exof/e-V fhorlu date into the Conf Iguration I.E anaiysis via the use of a serles of one-diemsional MisM calculations, which are faster and wore economical than the tro-dimenslonal DOT calculations.

The first step in the techniqu was to perform a 76-group one-dimensional MISN calculation for Contiguration I.E with the sawe ERDF/B- ir cross sections that had been eployed In the original tro-dicensional DOT enalysis. The DOT-to-kils ratio could then be usad as a scal ing factor to convert one-diansional results to tro-dimensional

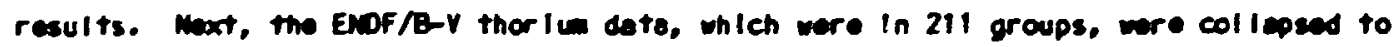
the 207 groups required by the VITAMIN C LIbrery (171 noutron groups and 36 gener oy groups) and conbinod with the nom-thor Iun dete of the GCFR Exf/B-IV croserection set that hed been processed Into the 207-group stricture. The cambinad dota sat was then used In en MISN calculetion for Conflgur ation I.E, and the results vere witiplied oy the scaling fecter to obtein the compertible tro-dimensional resul's. But to nate a 
direct comparison with the EDF/B-iv thoriu cross sections, It wes necessery to also

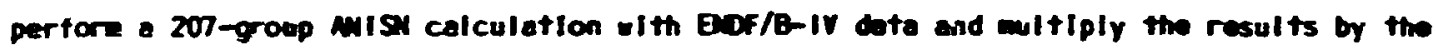
scalling fector. A copporison of the two scaled 207 -group calculaticns then showed the

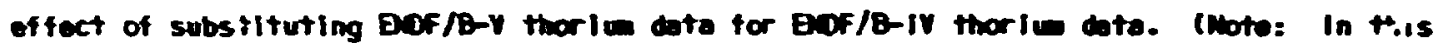

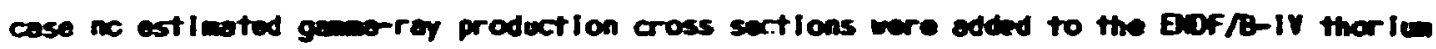
dato set.)

The nectron and gemeroy spectro resulting frre the two scaled celculations ore comared with tice nosured spectra in figs. 8.19o-b. The two calculated neutron spectro differ by 20 to 405 between 0.1 and $3 \mathrm{kvl}$, with the Eof/B-r risults showing the better

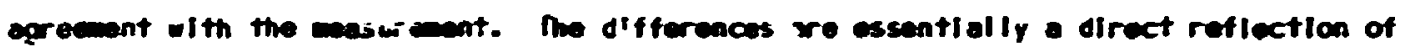
the oifferences bermeen the total inutron cross sections for EDf/O-IV and shom In FIg. 8.20.

The gena-ray spectra in Fig. 8.150 show thet without the estinated thorlin gansray production cross sections added t, the EDf/B-IV data the calculation severely underestiectes the gano-ray spectru in ol ' energy regions. The EDF/B-V dato

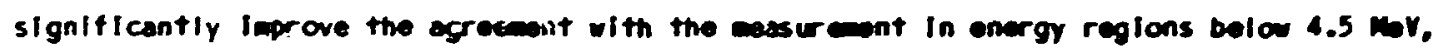
but the calculated results arg still too lan by a fector of 2 is 3 . Noove 4.5 mar, both cross-section sets underestinate the nasured suactrus oy about a fector of 30 . In oddition. the poaks In the calculated spactre apper at a olfferent enorgr then the peck In the nasured spectrum.

The large discrepancy botween oll the calculated gameroy spectra and the wesured

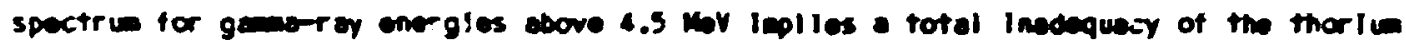
cross sections for predicting the production of higbeneror gemereys. Hower, when the fluxes that were obteined within Conflguration I.E by the sceled Nilsu calculation using the ERDF/B-Y thorifo date were folded with the no response functions, the

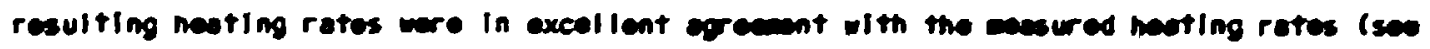
Toble 8.6). This supgests that the proble wes not within the cont lguration but ratmer beyond it - pertices in the eaceserents or In the technique for projectimg the celculated generay fluxes fram the end of the conflguretion to the lacetion of the

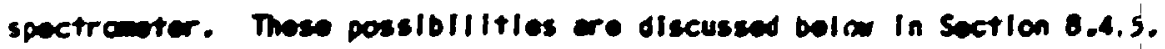



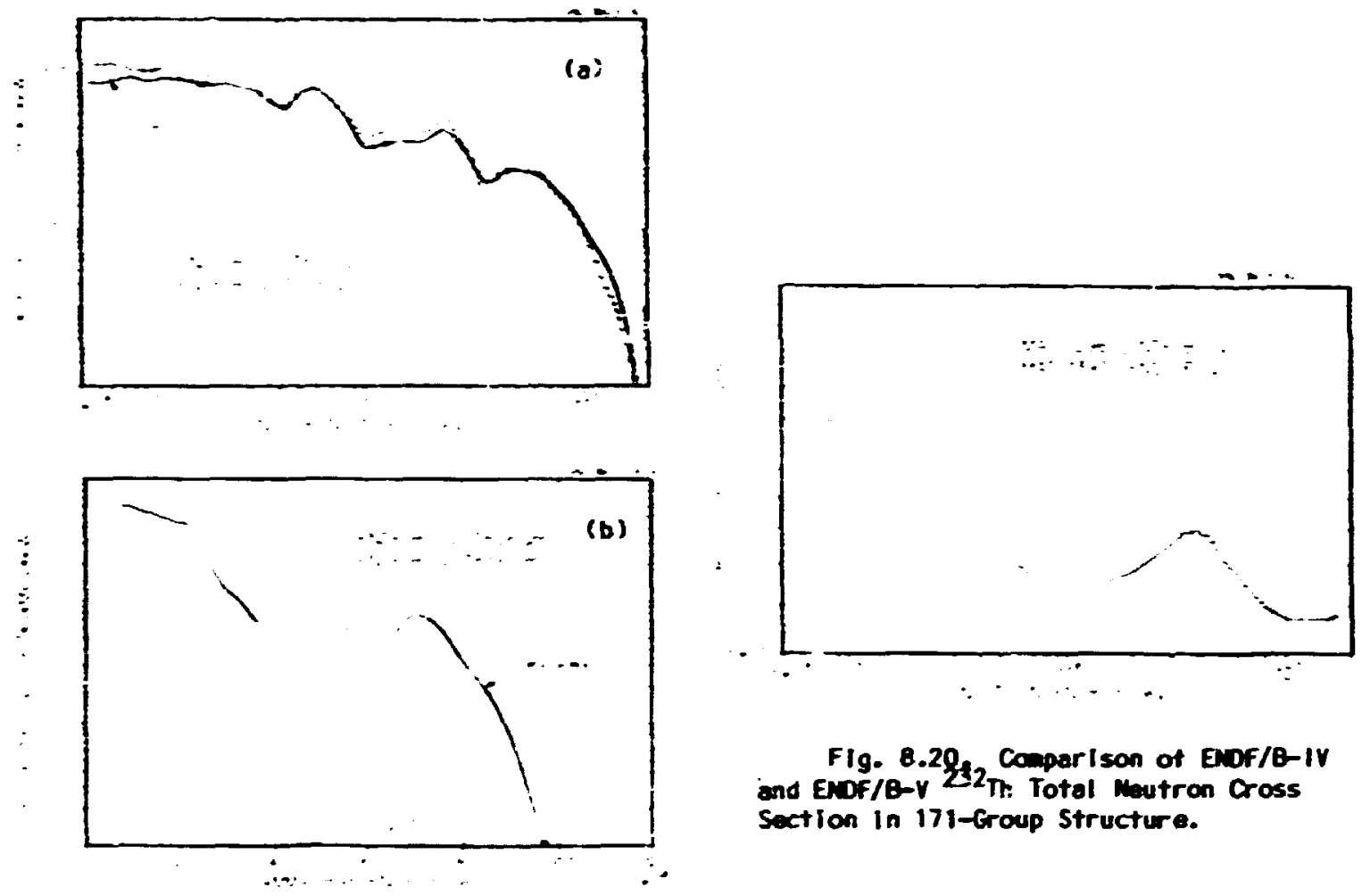

FIg. 8.29, Comparison of ENDF/B-IV and ERDF/B-V $232 \mathrm{~T}$ : Total Wutron Cross Section in 171-Group Structure.

FIg. 8.19. Comparison of Moutron and Gementioy Spoctra mesured 1296.4 an Beyond Blanket Conf Igur ation I.E with Spactra Calculated with EDF/B-IV and $-V$ Thor IU Data. (Note: AII non-Th dato are ENOF/B-IV in both calculations; no Th gaceno-ray-production data In ERDF/B-IV Th dato-)

Table 8.6. Comparison of Mesured (TLD) Heating Rates in Conf igur ation I.E with Hoating Rates Calculated with EDf/B-IV and $-V$ Thorlum Cross Sections

\begin{tabular}{|c|c|c|c|c|}
\hline \multirow[b]{2}{*}{ Calculation } & \multicolumn{4}{|c|}{ Calc./Mas. } \\
\hline & Vold & $\begin{array}{c}\text { Vold } \\
2\end{array}$ & ${ }_{3}$ & Vold \\
\hline $\begin{array}{l}\text { 2-0 76-group calculation using ENDF/B-IV } \\
\text { deta plus estinated th gana-roy pro- } \\
\text { duction date (original analysis) }\end{array}$ & 0.56 & 1.25 & 1.37 & 1.34 \\
\hline $\begin{array}{l}\text { Scaled it } 207 \text {-group cal culation using } \\
\text { Enof/e-iv deta (no Th game-ray pro- } \\
\text { duction date incl udad) }\end{array}$ & 0.48 & 0.36 & 0.31 & 0.37 \\
\hline 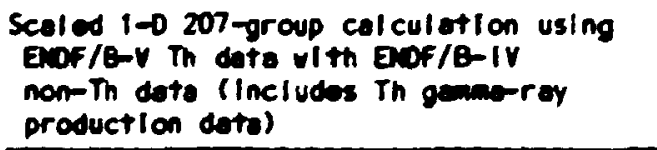 & 0.54 & 1.01 & 1.08 & 1.00 \\
\hline
\end{tabular}


8.4.4. Transport Calculations for Shield Conf Igurations

As has been describec In Section 8.2, the success! ve shleld configurations tested during the experiment priaarily consisted of the sectlonal bull dup of the Inner and outer radial shlelds specified In Table 8.1 for the CSC.l reference design. In sone cases, hovever. the shield regions were preceded by a $\mathrm{UD}_{2}$ blanket rather than a Tha blanket, and In other cases alternate shields were substituted for reglons of the reference shield.

As noted in Table 8.1, the CSC.I design speclfles that the first rou of the reference Inner shield be 12.7 o of a B.C-graphlte wixture between stainiess steel walls and that the second rom consist of $15 \mathrm{~cm}$ of stainless steal, the two rows beling separated by a 5.1-cin hellumillied gap. In the experiment the Inner shield was simulated by three configurations: Cont Igurations III,A and III.8, wich wocked up the design through the first and second rous, respectively, and Configuration II.B, wich mocked up the design through both rows but utllized a $\mathrm{WO}_{2}$ bienkei rather than a ThO $\mathrm{T}_{2}$ blanket (see FIgs. 8.7 and 8,6 ).

The results of Bonner ball measurements and the corresponding calculated-to-neasured ratios for varlous detector locations behino the inner shleld configurations ore presented in Teble 8.7. As wight have ben expected, the ratlos are very siallar to those observed for the blanket configurations; that Is, for the conflgurations Including $\mathrm{ThO}_{2}$, the calculations general ly overpredicted the measurements, whlle for the configurations liacluding $\mathrm{UO}_{2}$, the calculations ganeral ly underpredicted the meesurements. Thus the discrepancles noted In the calculations for the blanket conf Iguratlons (see Saction 8.4.3) persisted through the shie' I conflgurations - to the extent that it was Iffflcult to ascertain how accurately the transport through the shlelos thensel ves was predlcted. And the same trends were epperent In the ratlos of the Bonner Dall responses for two alternate shleld configurations (V.B and V.C), al so shown in Table 8.7 (see conflgurations ir FIg. 8.9).

Neutron spectra were measured bohlnd the verlous conflguratlons at the seme location at which the most distant Bonner ball masur cments were made, and an exealnation of the corresponding calculated spectra indicates the energy reglons contributing to the 
Table 6.7. Calcul eted-to-keesured Bonner Ball Responses Beyond Inner Shleld Conf Igurations

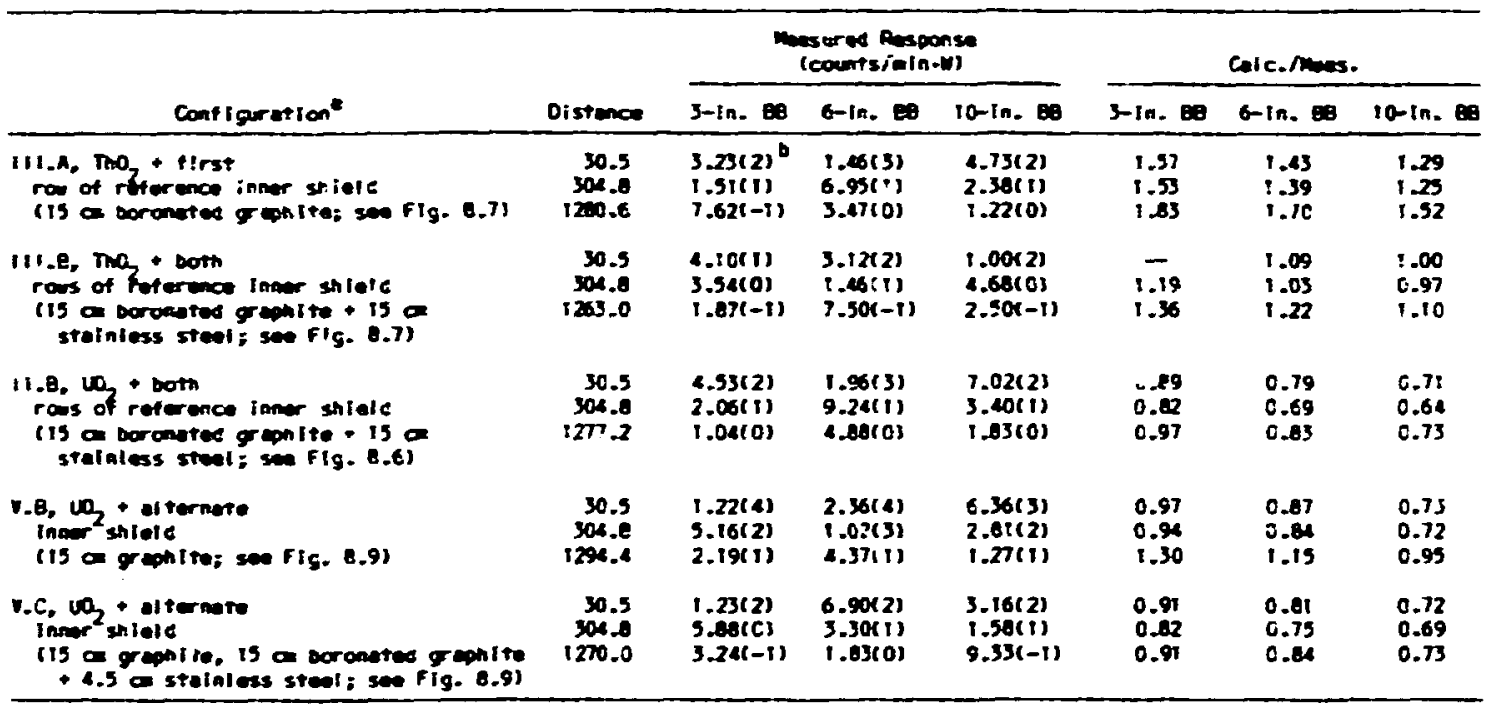

sice thicknesses inclicated are nopinal micknossas.

Prace: $3.23 \times 10^{2}$.

discrepancies in the calculated Bonner ball responses. Figure 8.210 shows, for example, that for Configuration III.A the calculations overpredicted the neutron fluxes below about 2 MeV but correctly predicted those above 2 MeV. With the addition of 15 an of stainlass steel to form Configuration III.B, the calculated spectrum only silghtiy overpredicted the asured spectru in the law-energy reglon and underpredicted it above $4 \mathrm{MeV}$ (see FIg. $\mathrm{P} ; 3$ ). For both configurations the relatively broad structure apparent In the measurements was calculated well.

For the configurations containing $\mathrm{WO}_{2}$, the calculations ylelded a silight underprediction of the neutron fluxes over the entIre spectrun (see FIgs. 8.23 - 8.25), but, In general, the egrement is consldered to be satistectory.

As was the case with the blanket contlguratlons, the genarray energy fluxes calculated for the spectrometer location beyond the Inner shield configurations were underpredicted in the analysis, severely so for the contlgurations contalnIng the $\mathrm{ThO}_{2}$ blanket (III.A and III.B) and substentlally so for the conflgurations contalning the $\mathrm{UO}_{2}$ blenket (II,B, V.B, and V.C) (see FIgs. 8.21-8.25). The posslble reasons for thase lerge discrepencles ore discussed in Section B.4.5. 

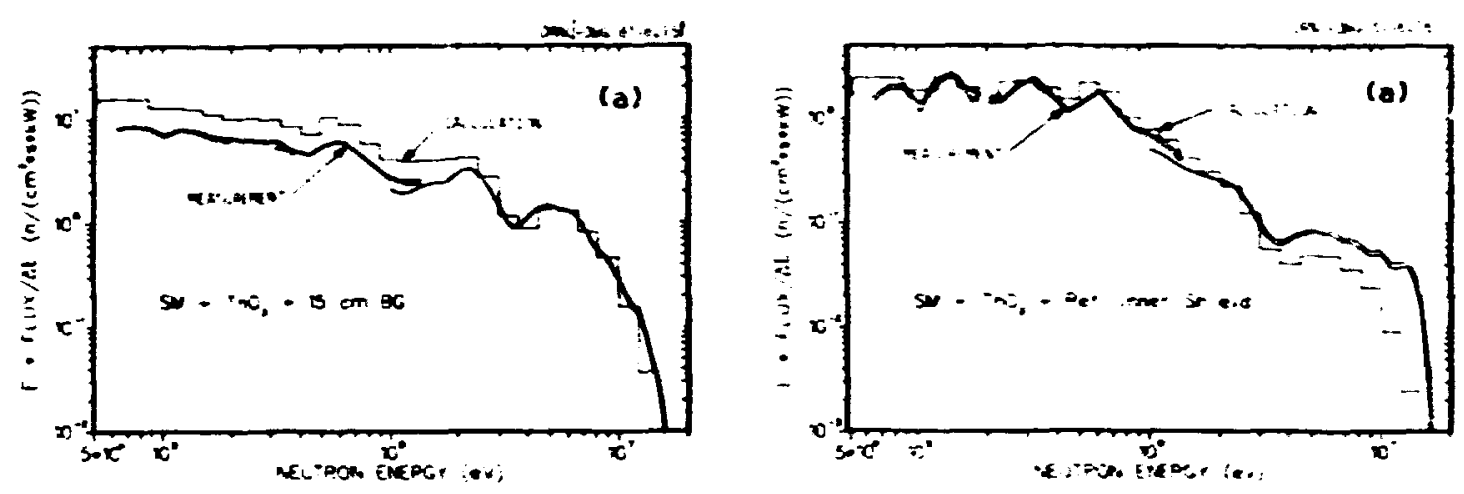

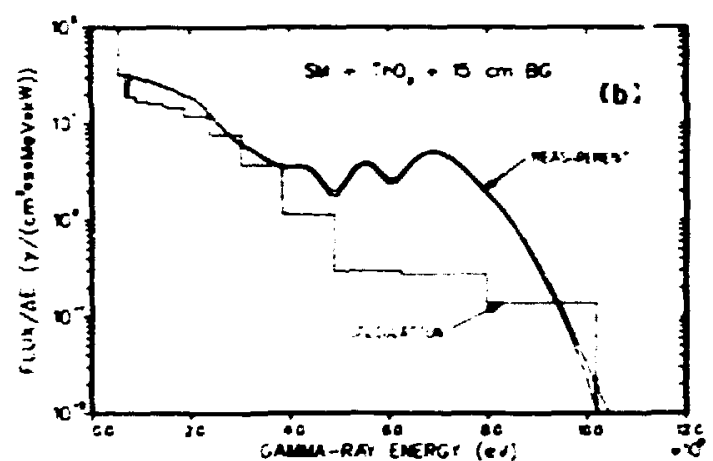

Fig. 8.21. Comparison of Heasured and Calculated Neutron and Gama-Roy Spectra 1280.6 a deyond Con' Iguration III.A.

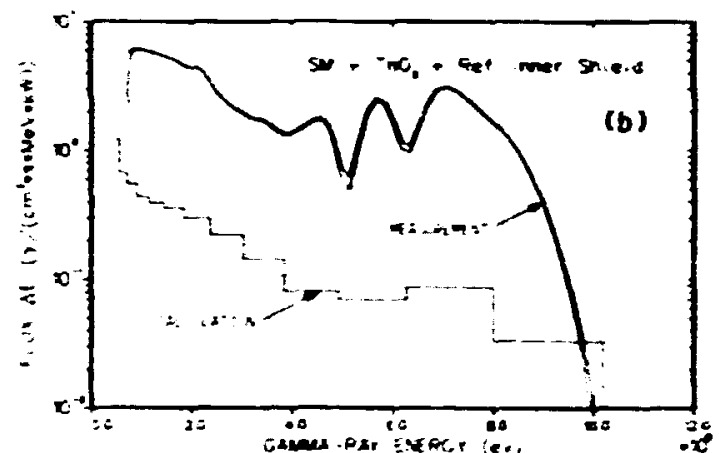

FIg. 8.22. Comparison of Mesured end Calculated Neutron and Gom-Ray Spectra 1263 an Beyond Conf igur ation III.B.

Comparisons of the calculated and measured TLD heating rates in the inner shield conflgurations are shown in Table 8.8. It wll be notec that in the first two cases, the comparisons are made for different but simllar calculations. ThI: is because TLD measurements had not leen made in the configurations that were calculioted (and vice versa); therefore the calculated TLO heating rates were compered with those neasured In similar conflguatlons that had been extended with additlonal meterlals. Unfortunately the extensions, which in one case Included the outer shleld (Conflguration IV.D), appeared to affect the measurements. For the case In which the calculations and meosurcments were mode for the same conf lgur ation (V.C), the egrement was very good.

For Investlgetlons of the full CSC.l shleld, the reference outer shleld was added behind the reference Inner shleld In sectlons. As stown in Table 8.1, the CSC.1 ceslgn speclfles that the outer shleld conslst of $5.1 \mathrm{~cm}$ of type 316 stainless steel, 5.1 on of 

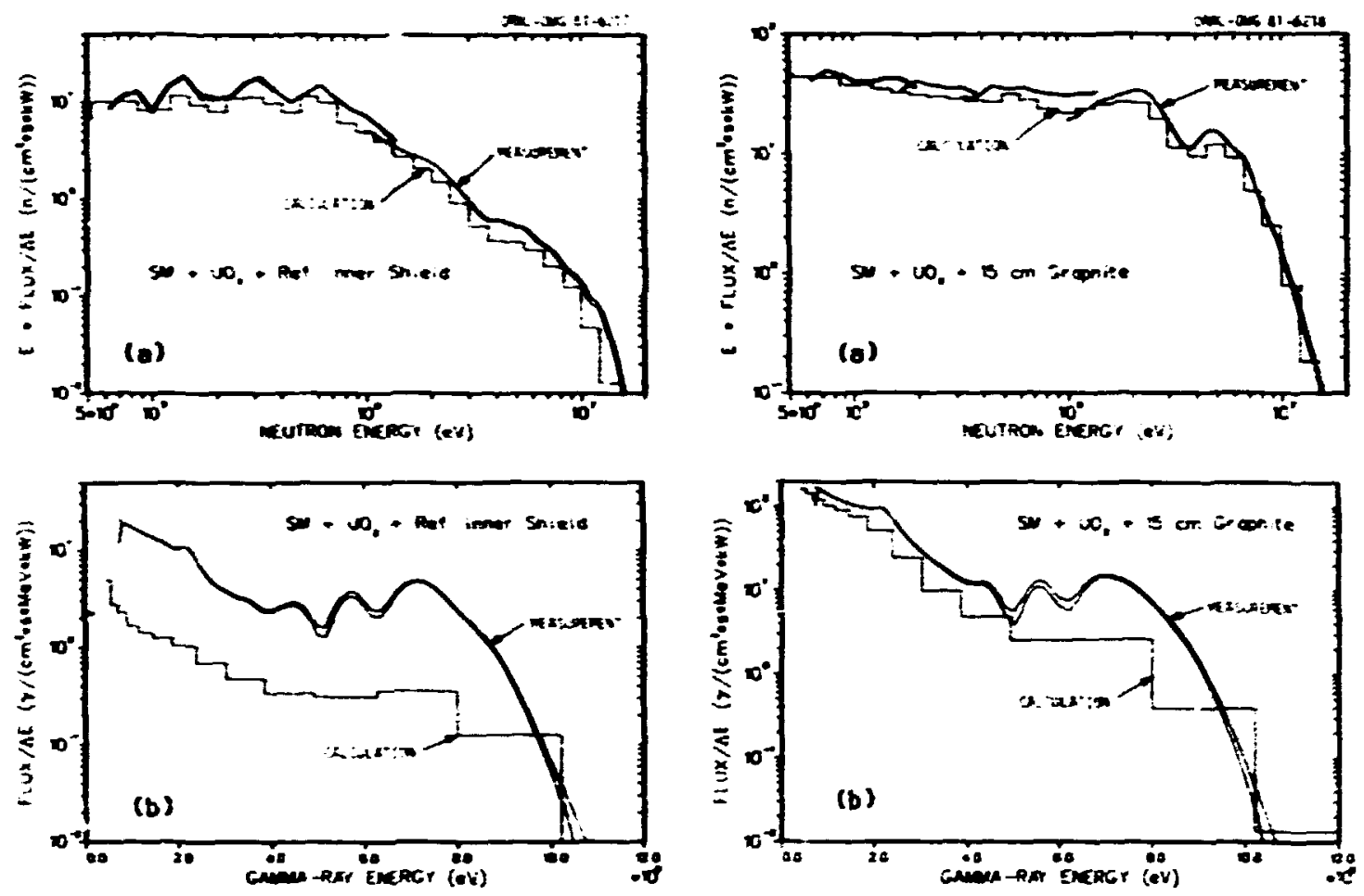

Fig. 8.23. Comparison of measured and Colculated Neutron and Gama-Roy Spectra 1277.2 a Beyond Conf Iguration 11.8.

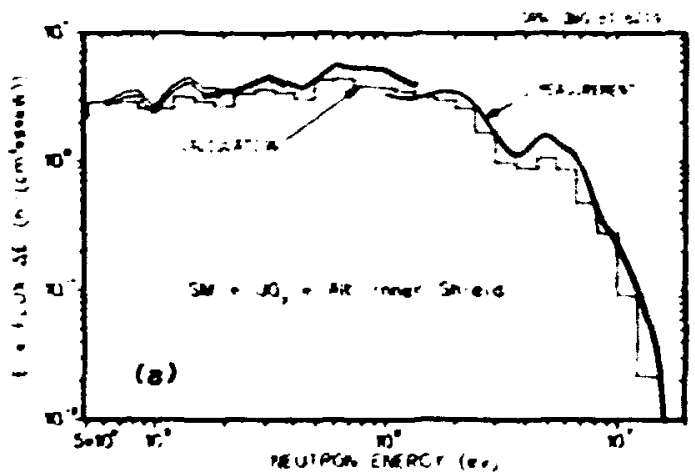

boronated graphite, $22.6 \mathrm{~cm}$ of stalnless steel, $5.1 \mathrm{~cm}$ of boronated graphlte, and 5.1 an of type 316 stalnless steel. Cont Igurations IV.A through IV.C represent the bulidup of these sertions, with Conf Iguration IV.C abodyling the full shleld (see Flg. 8.8). In an additlonal

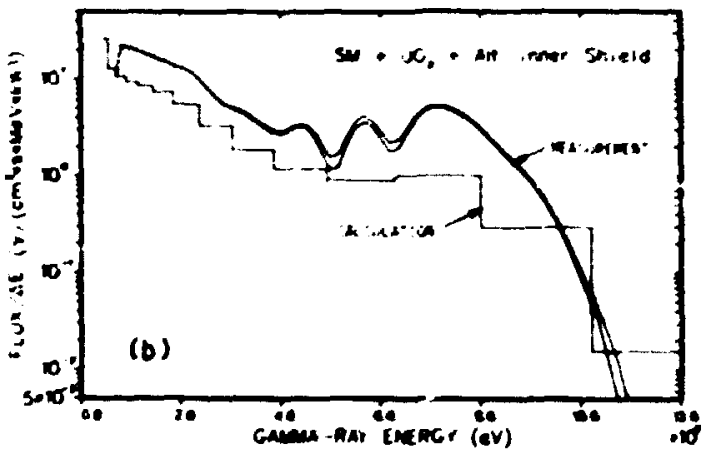

conflguration (IV.D) the rockup wes extended Into the PCRv. And, flinally, In one conflguration (IV.E) the $\mathrm{ThO}_{2}$ blanket of Conflgur ation IV.C was removed to Increase the counting rates beyond the conflguration and also to renove the uncerteintles essociated with the calculations of the

FIg. 8.25. Comparison of mesured and Celculated Neutron and Gome-Rey Spectra $1270 \mathrm{~cm}$ Beyond Conf lour ation V.C. 
Table 8.8. Comparison of Calculated and Measured (TLD) Heatling Rates In Inner Shield Configurations

\begin{tabular}{|c|c|c|c|c|c|c|}
\hline \multirow[b]{3}{*}{ Conf Iguration } & \multirow[b]{3}{*}{ 'ocation } & \multicolumn{4}{|c|}{ Heating Rate $[$ MeVi $(g \cdot \min \cdot k$ W $)]$} & \multirow[b]{3}{*}{ Calc./Meas. } \\
\hline & & \multirow[b]{2}{*}{ Meas ured } & \multicolumn{3}{|c|}{ Calculated } & \\
\hline & & & Gameas & Neutrons & Total & \\
\hline $\begin{array}{l}\text { III.B (Caic.) } \\
\text { Y.E (Meas.) }\end{array}$ & $\begin{array}{l}V_{c} \cdot 1^{b} \\
\text { Vold } 2\end{array}$ & $\begin{array}{l}1.03(6)^{c} \\
2.08(5)\end{array}$ & $\begin{array}{l}9.81(5) \\
2.64(5)\end{array}$ & $\begin{array}{l}1.06(5) \\
1.47(4)\end{array}$ & $\begin{array}{l}1.09(6) \\
2.80(5)\end{array}$ & $\begin{array}{l}1.06 \\
1.34\end{array}$ \\
\hline $\begin{array}{ll}\text { II.B (Calc.) } \\
\text { IV.C (Meas.) }\end{array}$ & $\begin{array}{ll}\text { Yold } 1 \\
\text { Yoid } 2\end{array}$ & $\begin{array}{l}5.60(4) \\
8.50(3)\end{array}$ & $\begin{array}{l}8.01(4) \\
9.77(3)\end{array}$ & $\begin{array}{l}2.72(3) \\
5.66(2)\end{array}$ & $\begin{array}{l}8.28(4) \\
1.03(4)\end{array}$ & $\begin{array}{l}1.48 \\
1.22\end{array}$ \\
\hline v.c & $\begin{array}{l}\text { Yoid } 1 \\
\text { Vold } 2 \\
\text { Yoid: }\end{array}$ & $\begin{array}{l}1.98(6) \\
1.02(6) \\
1.35(5)\end{array}$ & $\begin{array}{l}1.77(6) \\
9.86(5) \\
1.43(5)\end{array}$ & $\begin{array}{l}i .94(5) \\
6.6(4) \\
2.72(3)\end{array}$ & $\begin{array}{l}1.96(6) \\
1.05(6) \\
1.46(5)\end{array}$ & $\begin{array}{l}0.99 \\
1.03 \\
1.08\end{array}$ \\
\hline
\end{tabular}

Tho meesurements mere not made for Configuratlons III.B and : I.B and calculations were not performed for Contigurations V.E and IV.D; therefore, the calculated and measured values compared are for different but similar inflgurations.

birst vold following spectrum modifler; see vold locations in Fig. 8.6 (11.B), Fig. 8.7 (III.B), Fig. 8.8 (IV.D), Fig. 8.9 (V.C), and Fig. 8.11 (V.E).

$C_{\text {Read: }} 1.03 \times 10^{6}$.

The analys.s of the outer shleld conf Igurations was conf Ined to Conf igurations IV.C and IV.E. Ratlos of the calculated and measured Bonner ball responses iur inese configurations are given in Table 8.9, and the calculated and measured neutron and gama-ray spectra beyond configuration IV.E are presented in FIg. B.26. The calculated and measured Bonner ball responses are in good agreamer.t for both conf Iguratlons except for the $3-i n$. and $6-i n$, detectors at the most distant locations. The calculated and measured neutron spectra for Conflguration IV.E are also in good agreanent except for nne energy reglon in which It appears that one of the three hydrogen counters used in the measurements was in error. As in other cases, the calculated and measured gameray spectra are in dlsagreenent, though less so than for the earller cases. The gamaray spectro have strong simllarity to the spectra given In FIg. 8.25 for Configuration V.C.

While it hjs been shown in the preceding discussion that in most cases the calculoted and messured neutron responses tor the conf iguretions conteining the shleld reglons ore In relatively good agreement, It is also apparent that the Interpretation of the celculations of the trensport through the shield reglons is complicsted by the uncertaintles In the calculated transilssion through sectlons preceding the shleld reglons. Thus to better understend the attenuation charecteristics of the shlelds 
Table 8.9. Calcul oted-to-measured Bonner Ball Responses Beyond Ful I (Inner Plus Outer) ShIeld Conf Igurations

\begin{tabular}{|c|c|c|c|c|c|c|c|}
\hline \multirow[b]{2}{*}{ Conf Iguration } & \multirow[b]{2}{*}{ Location } & \multicolumn{3}{|c|}{$\begin{array}{l}\text { Mosured Rosponse } \\
\text { (counts/min-w) }\end{array}$} & \multicolumn{3}{|c|}{ Colc.Mnos. } \\
\hline & & 3 -in. 80 & $6-\ln .60$ & 10-In. 89 & $3-\ln .68$ & 6-in. 80 & $10-\operatorname{In} .88$ \\
\hline $\begin{array}{l}\text { IV.C, } \mathrm{ThO}_{2}+\text { referense } \\
\text { Innor shleld + reference } \\
\text { outer shield (see FIg- 8.8) }\end{array}$ & $\begin{array}{r}30.5 \\
304.8 \\
1210.5\end{array}$ & $\begin{array}{l}2.32(-1)= \\
1.08(-2) \\
5.71(-6)\end{array}$ & $\begin{array}{l}6.54(-1) \\
2.08(-2) \\
1.81(-3)\end{array}$ & $\begin{array}{l}1.06(-1) \\
0.76(-3) \\
6.12(-4)\end{array}$ & $\begin{array}{l}1.08 \\
1.04 \\
1.38\end{array}$ & $\begin{array}{l}1.06 \\
1.13 \\
1.23\end{array}$ & $\begin{array}{l}0.98 \\
1.01 \\
1.00\end{array}$ \\
\hline
\end{tabular}

-Reod: $2.32 \times 10^{-1}$.
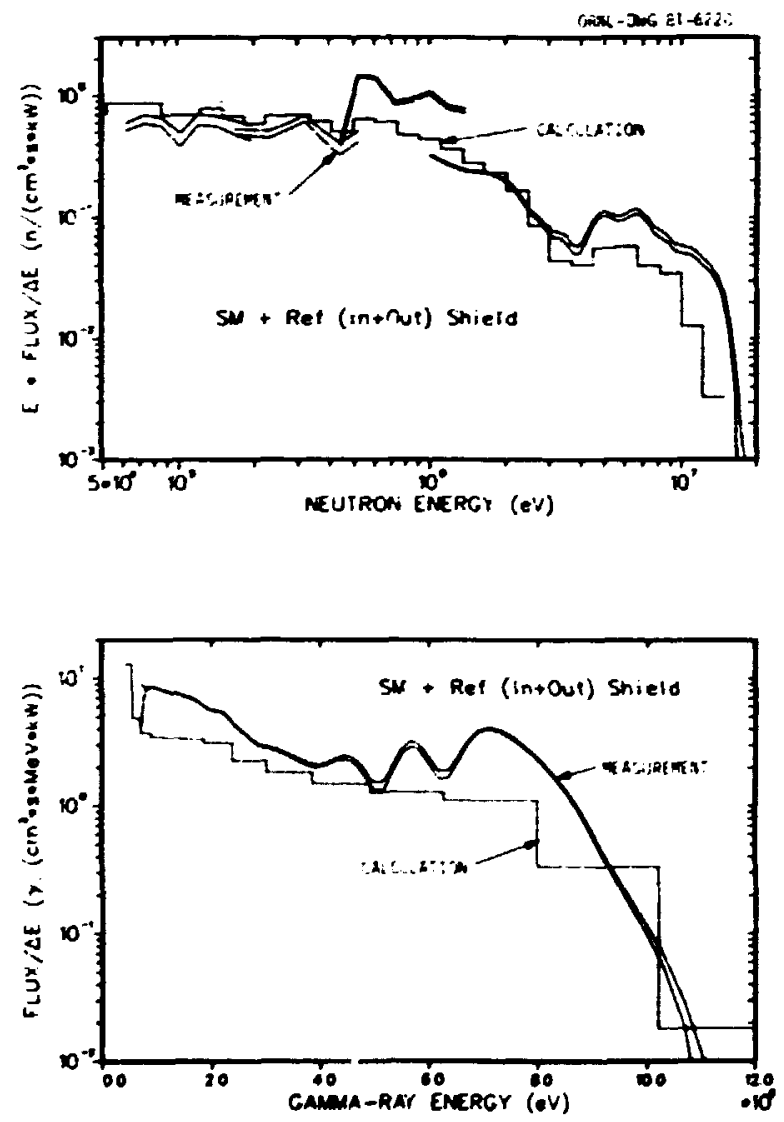

FIg. 8.26. Comparlson of Masured and Calculated Neutron and Germe-Ray Spoctra $1264.9 \mathrm{~cm}$ Beyond Conflguration IV.E. themsel ves, an approach was used In which a Bonner ball response for a configuration with a specific shleld region was "ratioed" with the response for the same configuration wth the shleld reglon removed, ttereby determining the attenuation factor for that region. The Ideal way to do this would be to compare the responses at a fixed and distant detector location beyond the two conf igurations, thereby ensuring that the same geometric attenuation would occur in both configurations and the difference in the responses would be entirely due to materlal attenuation within the shlelf reglon. However, difficulties encountered in calculating distant Bonner boll responses precluded the use of this technique, end, instead, the responses at a distance of 30 cin beyond each conf Iguration were used. As a rasult, the ottenustion factors determinad Include both geometric and moterlal attenuation. 
The resulting calculated and mossured attenution foctors and the corresponding calculated-to-mesured retios are presented Ir. -able 8.10 for several conflgurations. It Is noted that the attenuation factors for 15 a of boronated graphite are consistentily underpredicted and that those for the $15 \mathrm{~cm}$ of stainless steel are consistently overpredicted, the overal i result beling that reasonably good egrecment is obtalned for the cambined regions. Mnen 4.5 a of stalnless steel follars the boronated graphite the egreement is al so good. In fact, for nearly all the wultiregion shields the calculatedto-measured ratlos are consldered to be good. However, markedly different attenustion factors are obtalned for the full shleld with and without a preceding $T_{h} \mathrm{O}_{2}$ blanket (es in ConfIguration IV.E). WIthout the blanket, the attenuation In the fulf shleld was higher iv factars of 3 to 6 .

It was speculated that the larger attenuation factors for the full shleid without o preceding blanket vere due to differences in the spectre of the neutrons Incident on the shield, even though, as shown in FIg. 8.27. the spectrun emerging from the $\mathrm{ThO}_{2}$ blanket Is only moderately softer than the spectrum anerging fra the spectrum nodiffer. StIll, this difference Is apparently enough to ake the presence of the boronated graphite in the Initlal section of the shleld more effective. Certainiy the difference is real since It appears both In the measurenents and In the calculations for all three Bonner bal Is used.

Finally, overall, it appears that the neutron transalssion through the shleld configurations was well calculated.

\subsubsection{Examination of Gama-Ray Spectral Discrepancies}

It has been polnted out In the previous sections that large discrepancles were observed between the measured and calculated gamo-roy spectral moasurements beyond the varlous conflgurations but that the measured and calculated heoting rates within the conflgurations vere in good agremint. Therefore It appeared thet the problem orose outslde the configuretion, el ther in the measurements or In projecting the calculated fluxas to the spectrometer location. In an attempt to resolve the problem, several effects that wight heve been contributiig to the discrepancy were investigated. 
Table 8.10. Attenuation Factors ior Shleld Sectlons Determinad fran Ratlos of Bonner Ball Responsus $30 \mathrm{~cm}$ Beyone Conf Iguratlons

\begin{tabular}{|c|c|c|c|c|c|c|c|c|c|c|}
\hline \multirow[b]{3}{*}{ Shield Section(s) } & \multirow[b]{3}{*}{ Rat lo } & \multicolumn{9}{|c|}{ Atrenustion foctors } \\
\hline & & \multicolumn{3}{|c|}{$3-\ln .88$} & \multicolumn{3}{|c|}{$0-\ln .8 B$} & \multicolumn{3}{|c|}{$10-i n .88$} \\
\hline & & Colc. & Moss. & Celc./Moas. & Colc. & Mases. & Calc./Meas. & Calc. & Moas. & Culc./Moas. \\
\hline $15 \mathrm{~cm} \mathrm{~B}$ C-Graphite & I.E/III.A & 7.6 & 11.7 & 0.65 & 8.0 & 11.1 & 0.72 & 7.8 & 10.2 & 0.77 \\
\hline $15 \mathrm{~cm} 304-55$ & $M . N\|\|_{1}$ & $5.4^{\circ}$ & $4.3^{\circ}$ & 1.27 & 6.1 & 4.7 & 1.31 & 6.1 & 4.7 & 1.29 \\
\hline $\begin{array}{l}\text { Rof. Innor Shleld } \\
\text { lis com B C-Graphlte } \\
+ \text { is com Sou-sS }\end{array}$ & I.E/III.B & $40.9^{\circ}$ & $47.8^{\circ}$ & 0.86 & 43.8 & 31.8 & 0.91 & 97.9 & 48.3 & 0.99 \\
\hline Rot. Inner Shleld & $\|. N\| . \theta$ & 38.7 & 35.2 & 1.10 & 43.8 & 37.9 & 1.16 & 41.0 & 34.8 & 1.18 \\
\hline is cm Graphito & Y.AVY.E & 1.3 & 1.3 & 1.01 & 3.3 & 2.95 & 1.08 & 4.4 & 3.8 & 1.13 \\
\hline $\begin{array}{l}15 \mathrm{~cm} \text { B,C-Graphlte } \\
+4.5 \mathrm{~cm} 304-55\end{array}$ & V.BV.C & 106 & 99.5 & 1.06 & 36.7 & 34.2 & 1.07 & 20.4 & 20.1 & 1.02 \\
\hline Rot, Outer Shlela & $111.8 / 10 . c$ & $373^{\circ}$ & $328^{\circ}$ & 1.14 & i91 & 477 & 1.03 & 349 & 339 & 1.02 \\
\hline Fult $\sin 1010$ & I.NIY.E & $2.46(3)^{b}$ & $2.68(3)$ & 0.92 & $3.31(3)$ & $3.19(3)$ & 1.06 & $9.09(3)$ & $0.36(3)$ & 1.09 \\
\hline Full Shiola & I.E/IV.C & $1.54(4)$ & $1.63(4)$ & 0.95 & $2.41(4)$ & $2.48(4)$ & 0.97 & $2.63(4)$ & $2.60(1)$ & 1.01 \\
\hline
\end{tabular}

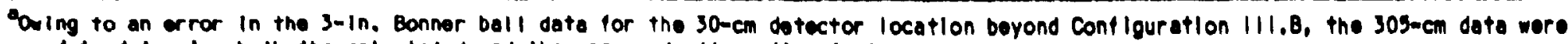
used to determine both the calculated and the measured ottenuation factors.

bread: $2.46 \times 10^{3}$. 


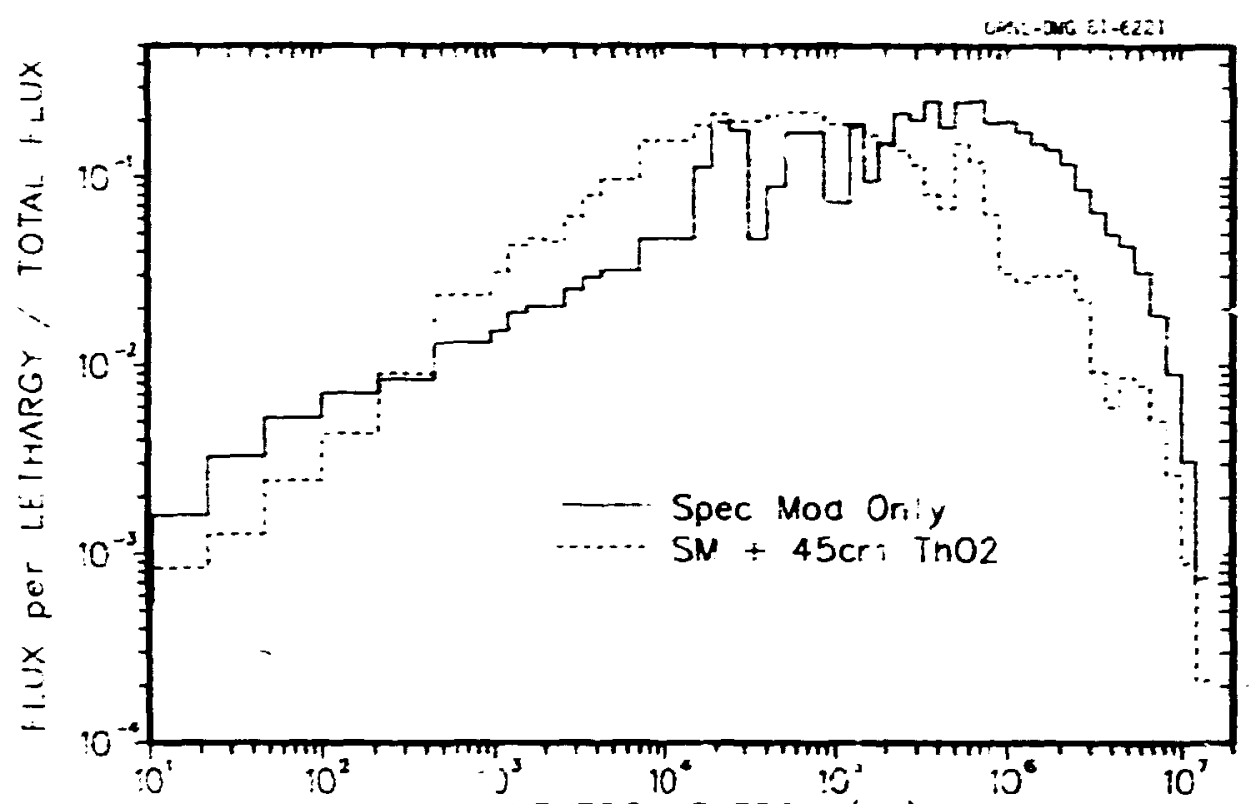

NEUTRON ENERGY $(\mathrm{eV})$

Fig. 8.27. Comparison of Spectr. Incldent on Fill Shifid in Configuration IV.E (Shield Preceded by Spectrua Modifier Q.ily) and Conf Isuratlo.i IV.C (Shleld Preceded by Spectrum Modifler Plus $\mathrm{ThO}_{2}$ Blanket).

One effect examined was the effect of the alr between the end of the conf Igur at! on and the detector. When $12 \mathrm{~m}$ of air was included in one-dimensional calculations in slab gecmetry, the gama-ray flux in most groups decreased 5 to $10 \%$ owing to attirivatlor. of the neutron flux; however, the gamo-ray flux in the 8- to 10-Mal group Increased 15 to 201, wth the maximu flux occurring appreximately 5 m behind the configuration.

In another one-dimensional calculation (for Configuration $11.2 ;$, the effect of using a $P_{8}$ angular expansion for the cross sections rather than a $P_{3}$ expansion was Investigated and found to have no effect.

The effect of the concrete blockhouse surrounding the sp.ctrameter was diso determined in a one-dimensional calculation in which the blockhouse was modeled as an InfInIte annular cylinder and the source (the nectron flux calculated for the retector position bayon. Conflguration $\mid 1 . B)$ was placed on the axial centerline. The energy group contalning the 2.2-Hal hydrogen capture gemmo ray Increased by 58 and other groups Increased less then 18.

A similar study of gemmo-ray production within the NE-213 spectraneter Itself Indicated that detector-born geme roys would increase the 1.8 - to 2.3-Mal group by 10 to 158 and most other groups by less than 58. 


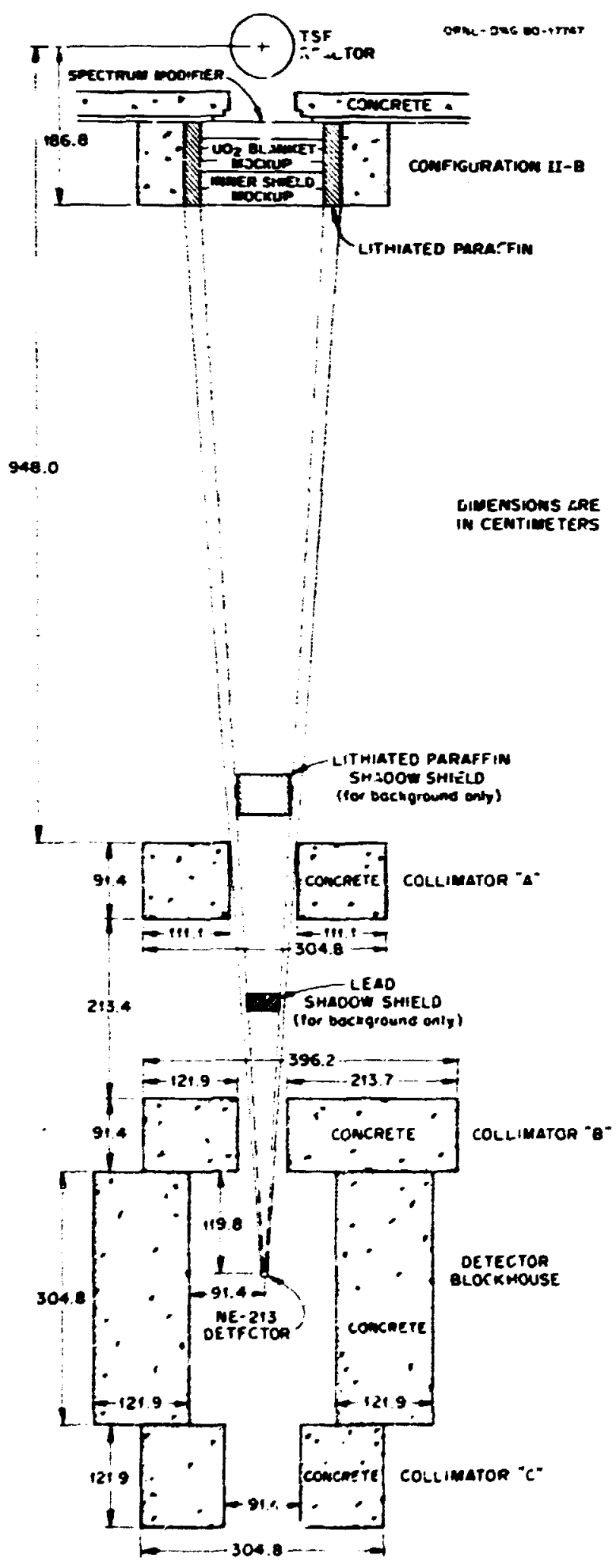

FIg. 8.28. Full Gecmetry for Spectral Mossur ements.
Whlle the abuve effects vere not of sufficient arsitude to account for the Iarge differences in the calculated ard mesured gamaray spectre, one additional effect did appear to largely explain the problen, and this had to do with the colliwotion of the gama-ray fleld Incldent on the ME-213 detector. As noted In TIg. 8.28, two large concrete coll limators were usad to restrist the angle of vilew of the spectronerer to the end of the mockup and the surrounding I ithlated paraffin. When background measurements were made only the Ifthlated parafin was viewed by tie detector; thus subtracting the background weasurement from the foreground measurement should have givon a net flux coming from the mockup itself.

Throughout the analysis of the expertment an "analytic collibator" was used In the FAL STF calculatlons to correspond to the experimental collimator. That is, only the flux coning from the end of the mockup Itself was consldered. When the calculations wore repeated without the andiytic collimator, the calculated gameray spectrum moved upward toward the masured spectrum unile the calculated neutron spectrum was unaffacted. A typlcal result (for configuration II.B) is shown in FIg. 8.29, and the apparent reason is Indicated in FIg. 8.30. That is, the gamerroy flux eppeers 


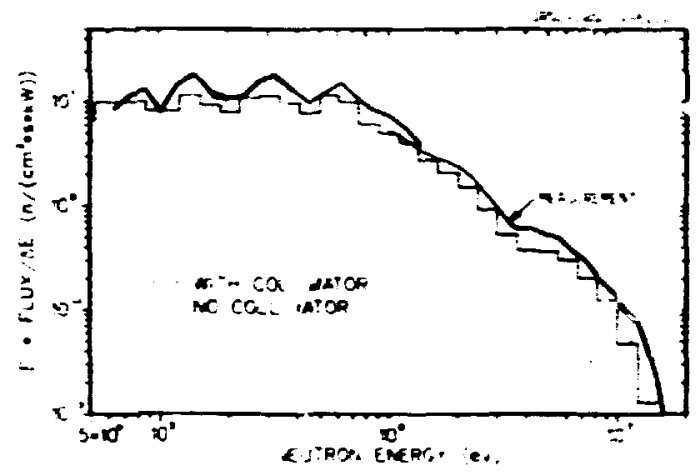

to be channeled through the I ithileted paraftin, resulting In a tlux exiting from the paraf in that cometes vith the flux exiting fram tine rockup itself. Since the angles def ined by the anelytic collinator Ir, the andiysis mers precise, the observed disegrecments appear to be due to the difflculty In accur..ely aligning the bulky collinators and shador shieids in the experiment. he overall conclusion is that an experiment designed primar Ily for neutron ceasurements way not be vell-suited for ganno roy asurements.

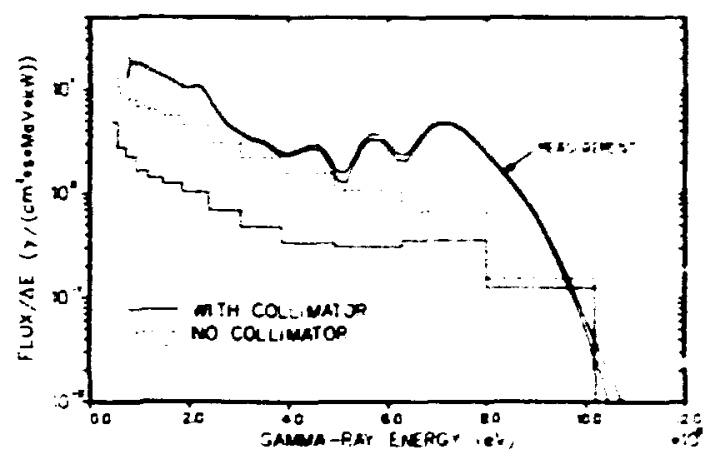

FIg. 8.29. Comparison of Masured Neutron and Gamo-Ray Spectra with Calculated Spectra 0b-sined with and Without an Anairtic Cc ! imator (Conflguration $(I . B)$.

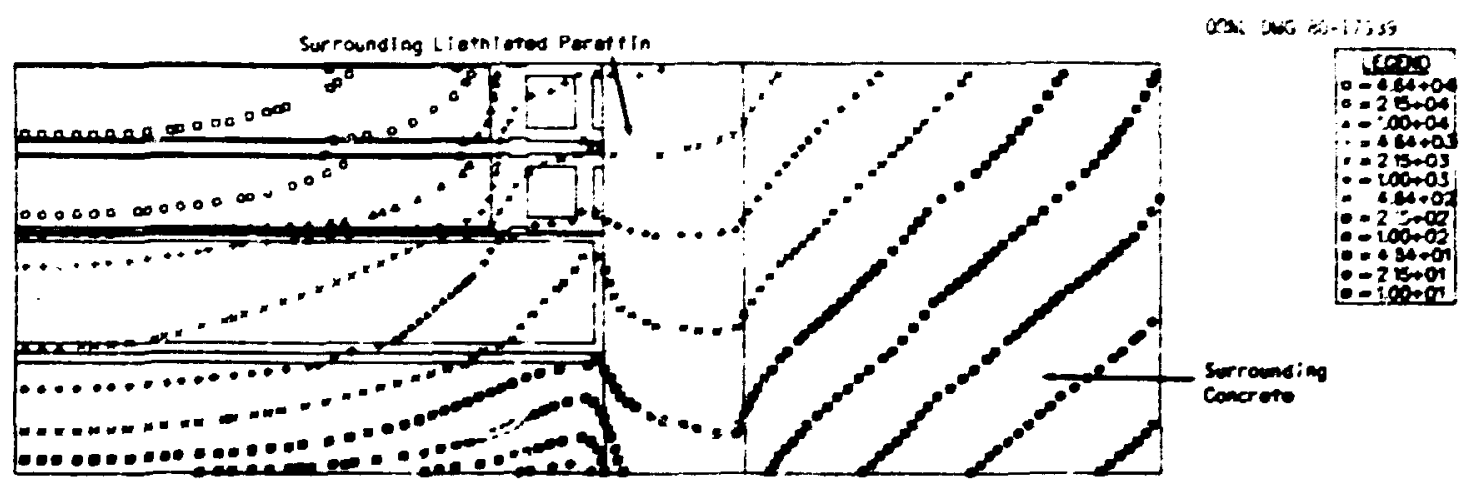

FIg. 8.30. Isoplot Contours for the Gamo-Roy filux above 1 Mav Emarging fron Con flguration II.B. 


\section{5. conausions}

By the tiwe the andysis of the GCFR radial shield confirwation experinent hed been completed, not only hed several ieportent design chenges been Introduced in the shield region, but work on the GCFR progran Itselt had bean suspended. Therefore the conclusions presented here are largaly llaited to those of generic value.

First. It was found that the neutron transission through $\mathrm{MnO}_{2}$ could be predctoo to

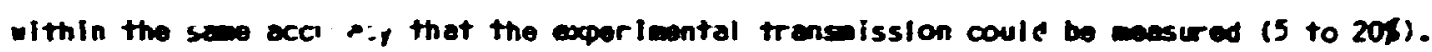
It res also found that neutron transeission through $\mathrm{UO}_{2}$ vas samentat underpredicted, but not by wore then 30\%. Comparisons of calculated and easured neutron spectra beyond the two blenket moterials showed falriy good agrement; novever, the calculated spectru for $\mathrm{ThO}_{2}$ wes silghtly higher then the wasured spectrue. Whon EDF/B-V cross sections for thorlu were substituted for the ENOF/B-IV cross sectlons used throughout the andiysis, the calculated spectru eoved closer to the enasured spectrun, especlal iy In the 0.1- to 3-inev region.

The predicted gaweray heating rates for vold reglons distributed in the $\mathrm{ThO}_{2}$ and $\mathrm{NO}_{2}$ blankets agreed wth the measured heating rates within the estimated uncertalntles of 5 to 158: however, the egrement for the $\mathrm{ThO}_{2}$ ol anket occurred only ofter the ENof/B-Y gama-roy production cross sections for thorlin were substituted into the calculation.

In contrast w ith the heating rates, the gamoray energy spectra at locations beyond the blankets were underpredicted - severely so for the $\mathrm{TnO}_{2}$ blanket, with no signlficant Improvements when ENDF/B-Y cross sections vere used. The largo underpredictions al so occurred beyond the conflguratlons that were extended with shield meterials, and a subsequent Investigation Indicatex thet the experimental design vas poor for gamoroy spectral casurcants outside the configuration. Speclficaliy. it was found that a Iithleted peraffin leyer surrounding the conf Iguretion providad a chenmel for game rays that competed with the greme roys emerging tron the conflguretion proper.

With respect to the shleld cont Igurations, the calculated neutron trensalssion

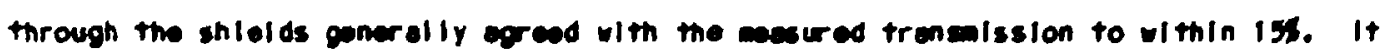
wes noted, hovever, thet the attenuating cherecteristics of Iealnated shields that contalned boron were dreaticaliy of fected by the spectral cherecteristics of the 
incisent fiux. Ir: particular, the attenution factors for tte full radial shielc las deterwinec fros Bonter ball responses) were higher by factors of 3 to 6 wen the Incl cent: seutrans rac energed frac the $\mathrm{ThO}_{2}$ blanket rather ttan from the spectru modifler simulating the GOFR core spectrua. The shlelt was also wo effective with a prececing $T_{h C_{2}}$ tienket trian with a preceding $\mathrm{NO}_{2}$ olanket (by 5 to $15 \%$ ).

Ir sumary, inen, the GCFR rzcial shielc confirmation experiment and its analysis save show. that a capebility exists for accurately predicting (i) the neutror tronsmission through thick $\mathrm{LC}_{2}$ anc $\mathrm{ThO}_{2}$ bienkets and lainated shields containing steel, graphite, ard boronated grapnite, (2) the gama-ray neating rates with in the configurations, and (3) the neutron spectra beyond the configurations. It has also confirmad the essentiality of using the froper source spectru in an experiment. And, finally. It has show that if an experiment is to include gamarray spectral measurements outside the configuration. special edditional cesign conslderaticas will be necessary.

\subsection{REFERENCES}

I. R. E. Naerker and F. J. Muckentheler, Winal Report on a Benchark Experiment for Neutron, Transport Through Iron and Stainless Steel," opal-4892 (April i974).

2. R. E. Yzerker, C. E. Clifford, and F. J. Muckenthaler, ENeutron Total Cross Section Crecks for Iror, Chromilu, Nickel, Stainless Steel, Soolun and Carbon," Opall-5013 (Aprii 1976).

3. D. T. Ingersoll and F. J. Muckenthaler, "Radial Blanket and Shield Experiment," p.

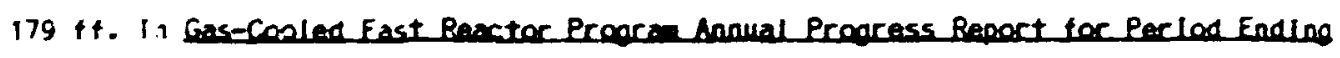
2ecentesc 31. 1976, ORRe-5560 (August 1979).

4. D. T. ngersoll and F. J. Muckenthaler, "Radiol Blanket and Shleld Experiment," p.

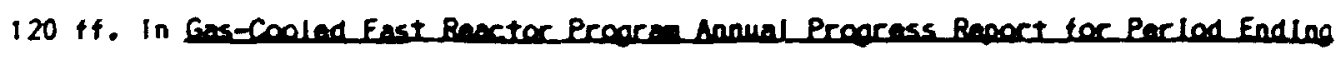
Decembar 31. 1979. ORall-5675 (November 1980).

5. D. T. Ingersoll, D. E. Bortine, and F. J. Muckenthaler, Design of Deep-Penetration Integral Experlment for Thorlum Blanket and Radial Shleld Mockups," Trans. Ma. Nuel. Soc. $32,643(1979)$. 
6. O. T. Ingersoll, U. E. Bartine, and F. J. Muckenthaler, GcFR Radial and Shleld Experiment: Objectives, Preanalysis, and Speclficetions," OPan/Th-6956 (Septeaber (979).

7. F. J. Muckenthaler, J. L. Hull, and J. J. Manning, GCFR Radlat Blanket anc Shielc Exper Iment," opul/Th-7237 (December 1980).

8. D. T. Ingersoll and L. R. Willias, Final Analysis of the GCFR Rad! al Blanket and Shield Integral Experieent," Ophil-5756 (April 1981).

9. D. T. Ingersoll and L. R. WIIIlans, "Analysis of the ORML-TSF Radial Blanket and Shiel d Integral Experiment," Trans. A. Mucl. 35, 4?0-472 (1980).

10. D. T. Ingersoll and F. J. Muckenthaler, Doep Penetration Integral Experimen! for a Tror iv Blanket Mockup." Nuclear Cross Sactlons for Iechnoloax 594, 122-!25 (1980): Proceedings of Internatlonal Conference on Nuclear Cross Sections for Technology, University of Tennessee, October 22-26, :979. 
9. GCFR PLENUM SHIELO STUOIES: OUTER PAOIAL SHIELO HE TEROCEIE ITY EXPEPIIENT

Experiment performed by:

F. J. Muckenthaler, J. L. Hull, J. J. Manning

Ane rsis performed by:

L. R. Willians, M. B. Emett

\subsection{Iitrocuction}

\subsection{The Experiment}

9.3. Measurec Resilts

9.3.i. Measurenents $\propto \propto$ Configurations 1: Singie Silts

9.3.2. Mezsurements for Configurations 11: Iron-Lined Single Silts

9.3.3. Measurements for Corfigurations III: Three-Slit Assemblies

9.3.4. Measisrements for Configurations IV: Offset Silts

9.4. Comparison of Measured and Calculeted Results

9.5. Reference 


\subsection{INTROOUCTION}

In the original schedule of GCFR-TSF shis: fing experiments, it was plarined that the series would end with four experiments to valldate the design of the system of GCF? plenu shlelds. However. Wlth the curtelimant of the GCFR progran, only two of the four experiments were completed, one described in this chapter and another described in Chapter 10. As used in this report, the system of GCFR plenum shlel ds includes both those shields surrounding the upper and lower plenuns above and below the core land specifically identified as plenu shields) plus several other constituent shields.

As it turned out, the two exfer lwents wost directly concerned with the shilelos surrouncing the plenum reglons were the two that vere cancel!ed. One experinent was to have intruramanec how the introduction of various types of oriflces in the shields would zompromise thelr shlelding effec: Iveriess. Becouse the hellum flowing through the ccre wil enter and leave through the pleaum shie!ds, they must be orificed at the !ocation of the hellium ducts, and severai types of orltices vere being consldered herringbone casign, chevron design, etc.l. The other experl ent was to have investigated neutron streaming and backscattering effects within the plenums themselves.

The two experimentc that were completed included one identified as the exit shield experiment, with is de:cribed in $\mathrm{Cha}_{2}$.er 10, and another identlfied as the outer radlal shlelo heterogeneity exper inent, which is the experiment described In this chapter. The outer radial shieis is ccnslderac to be part of the plenum shleld system because it Iles between the upper and lower plenum shlelds and is contiguous with then. Tests of the outer shield were Included is the experiment described in Chapter 8 and the heterogenelty expeilimert reported here is actually a refinement of that part of the earller experlment.

As described in Chapter $E$, the outer radial shleld li,cluded in the CSC.l design was specifled to be a permanent shielo consisting of 22.6-cri-trick blocks of graphite bounded on each slce by $5.1 \mathrm{~cm}$ of boronated graphlte anj clad ith $5.1 \mathrm{~cm}$ of stainless steel. To simplify the gecmetry In the experiment, the shleld was mocked up with solld layers of graphite, boronated graphite, and steel. In the actual design, however, the outer radial shield consists of several interwoven pleces enclosed in stainless steel envelopes (seo Fig. 9.1.). With this design the question arose os to whether excessive neutron streaning might occur between abutting pleces, and it was deened necessary to study neutron 
2PLL-DWG 80-11858

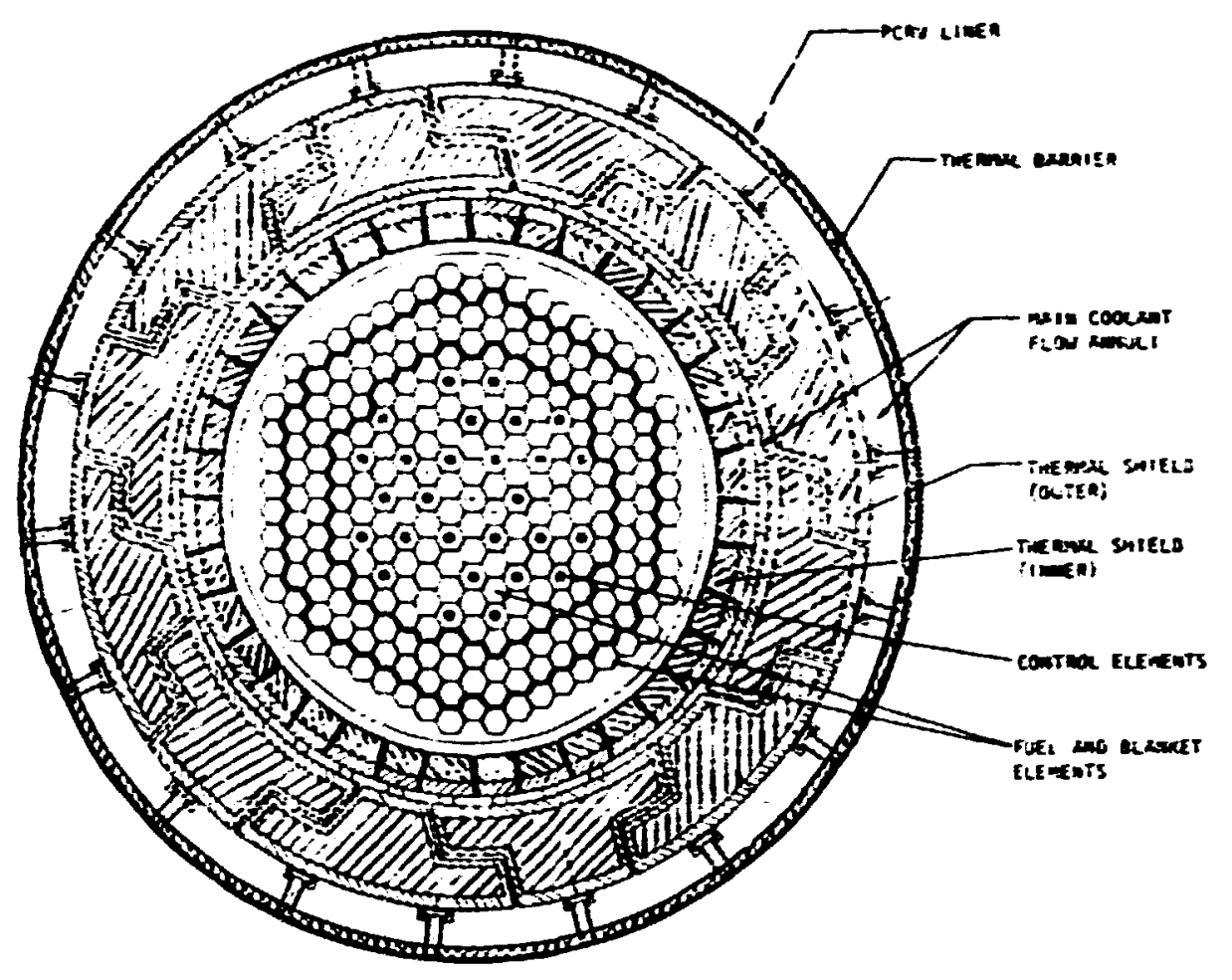

Fig. 9.1. Cross Sertion Through GCFR MIJplane. (See stepped silts through outer radial shie:d.)

streaning through shleld heterogeneitles typlcal of those that alght be present in the actual shleld. In addition, a benchmark experiment was needed to further check the analytical methods used to cesign the outer radlal shield. The experiment described here, performed In the sumer of 1980 and necessarlly abbrevlated because of the suspension of the GCFR program, was designed to provlde the required information. The var lous configurations used in the experiment are described In Section 9.2, and the evoerimental data are presented In Section 9.3. Section 9.4 then compares the measured results with the calculated results obtalned from a brlef analysis. (The exper Imont has a so been gescrlbed in ref. 1,)

\subsection{THE EXPERIMENT}

- G sasic experimentai conflguration consisted of 40.8 -cm thickness of graphlte 24-6*34: ef stralght or stapped vertical silts with and without cerbon steel IInings. 
The priacry criterion of the design vas to epproxiante the silt gecmetry and overall dimens! ans of the CSC.I outer radial shield without Incurrims the expense that would be assoclated with an exact nockup. Thus the 43-cm-thick multiregion radial shield of the CSC.1 desige that Inciudes graphite, boronated graphite, and stainiess steel loyers was nucked up with slabs of graphite alone (to a total thickness of $40.8 \mathrm{~cm}$ ) and the stainless steel envelopes surrounding exch block of the design sh!eld were mocked up with 5.1-ca-thlck "sheets" of carbon steal IIning only the silts. The graphlte slabs were each $10.16 \mathrm{~cm}$ on a slde and $121.9 \mathrm{~cm}$ long.

The experiment wos perforned in four pheses. In the first (Configurations I) two stacks of grapt ite slabs were separated to form 8 vertical silt at the rSR-II bean center I ine (see photograph of rockup in FIg. 9.2). The total heigint of the stacks was $162.6 \mathrm{~cm}$, but $20.3-\mathrm{cm}$ thlcknesses at the top anc bottom were offset, reducing the height of the slit to $121.9 \mathrm{~cm}$. The bea axis was $55.9 \mathrm{~cm}$ from the botton of the slit, and the slit width was varied from 0 to $10.2 \mathrm{~cm}$ (wldths $=0,0.635,1.27,2.54,5.08,7.62$, and $10.2 \mathrm{~cm}$ ). A sketch of the configurations through the horizontal midplane is shown in FIg. 9.3 .

In the secono phase of tha experinent (ConfIguratlons II), the stralght slit was IIned with carbon steel (see FIg. 9.4), and the sIlts were open at the top; that Is, offset graphite slabs were not used at the top and bottom of the conf Iguration. Agaln the slit width was varled (wldths $=0,0.635,1.27$, and $2.54 \mathrm{~cm}$ ).

For Configuretions III two additional stralght slits were li.troduced Into the mockup by moving each of the tro sections of graphite away from the steel iliners (see figs. 9.5 ond 9.6). In Conflguration III.A, all three slits were $0.635 \mathrm{~cm} w I d e$, but In Configurations III.B and III.C the outer slits were one-half the wIdth of the center sIIt, wich was 1.27 and $2.54 \mathrm{~cm}$ In $I I I . B$ and III.C respectively.

Configurations iv contalned a single stepped silt, which was formed by Introducing small sections of graphlte into the mockup as shown in FIg. 9.7. The first leg of the sIlt was maintalned at the TSR-II bean axis and the thIrd leg was maintalned at a radial distence of $30.5 \mathrm{~cm}$ fram the bean axis. In each configuration the length of the first 


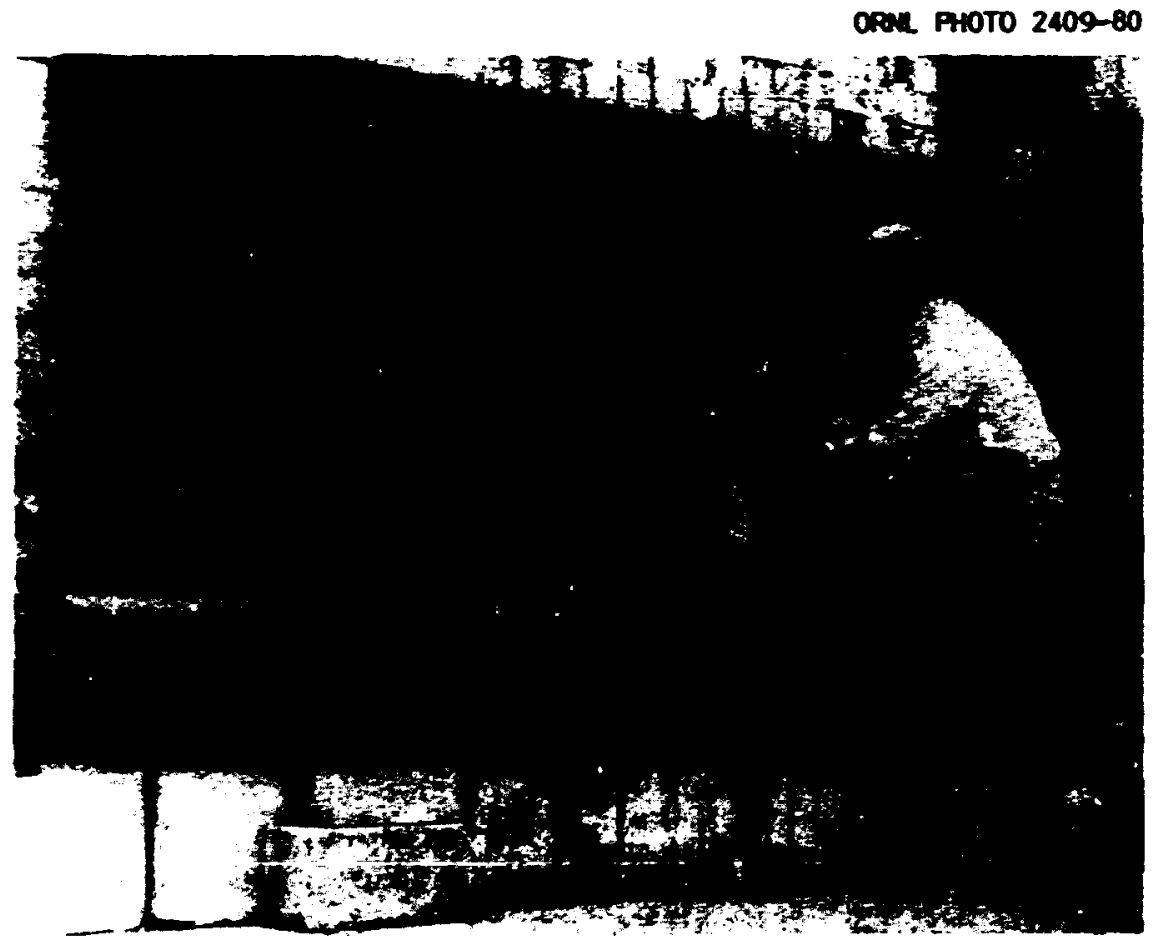

FIg. 9.2. Typical Mockup of the Graphlte Shleld with SIngle SIIt: Conf Igurations I.B, I.C, I.D, I.E, I.F, I.G.

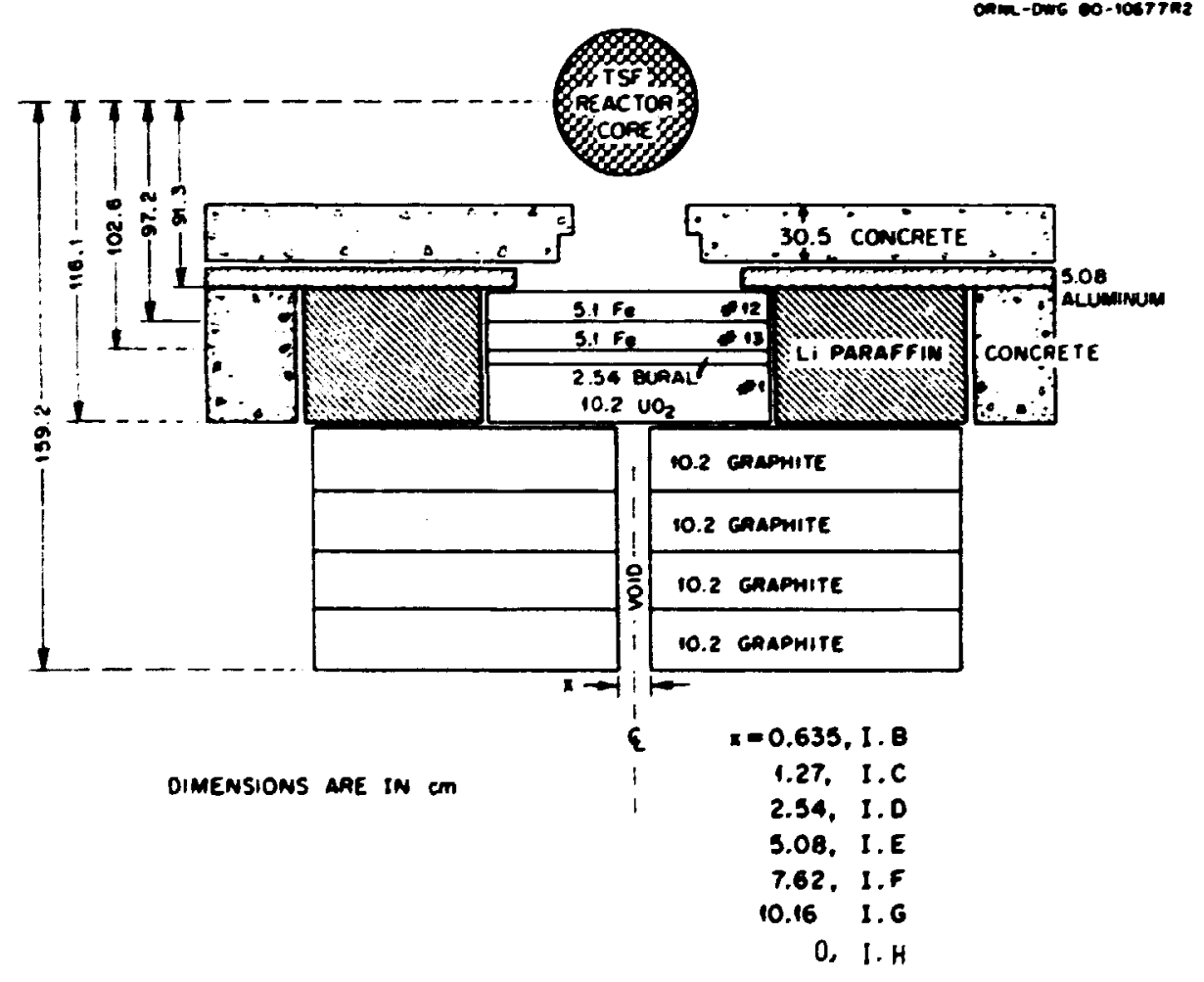

Flg. 9.3. Wockup of Outer Radial Shleld with SIngle Silti Conflgurations I.A I.H. 


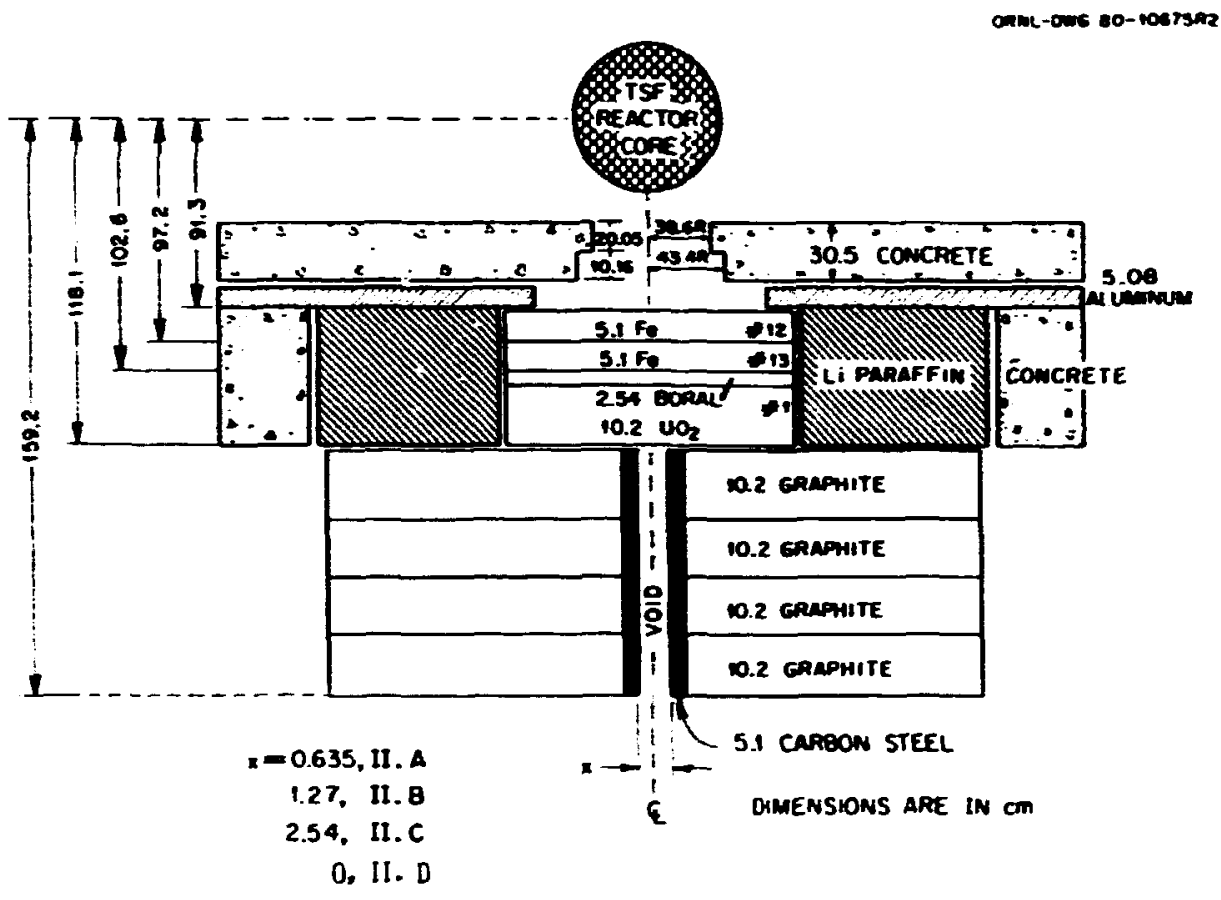

Fig. 9.4. Lockup of Outer Radial Shield with Iron-Lined Single Silt: Configurations $11 . A-11:$.

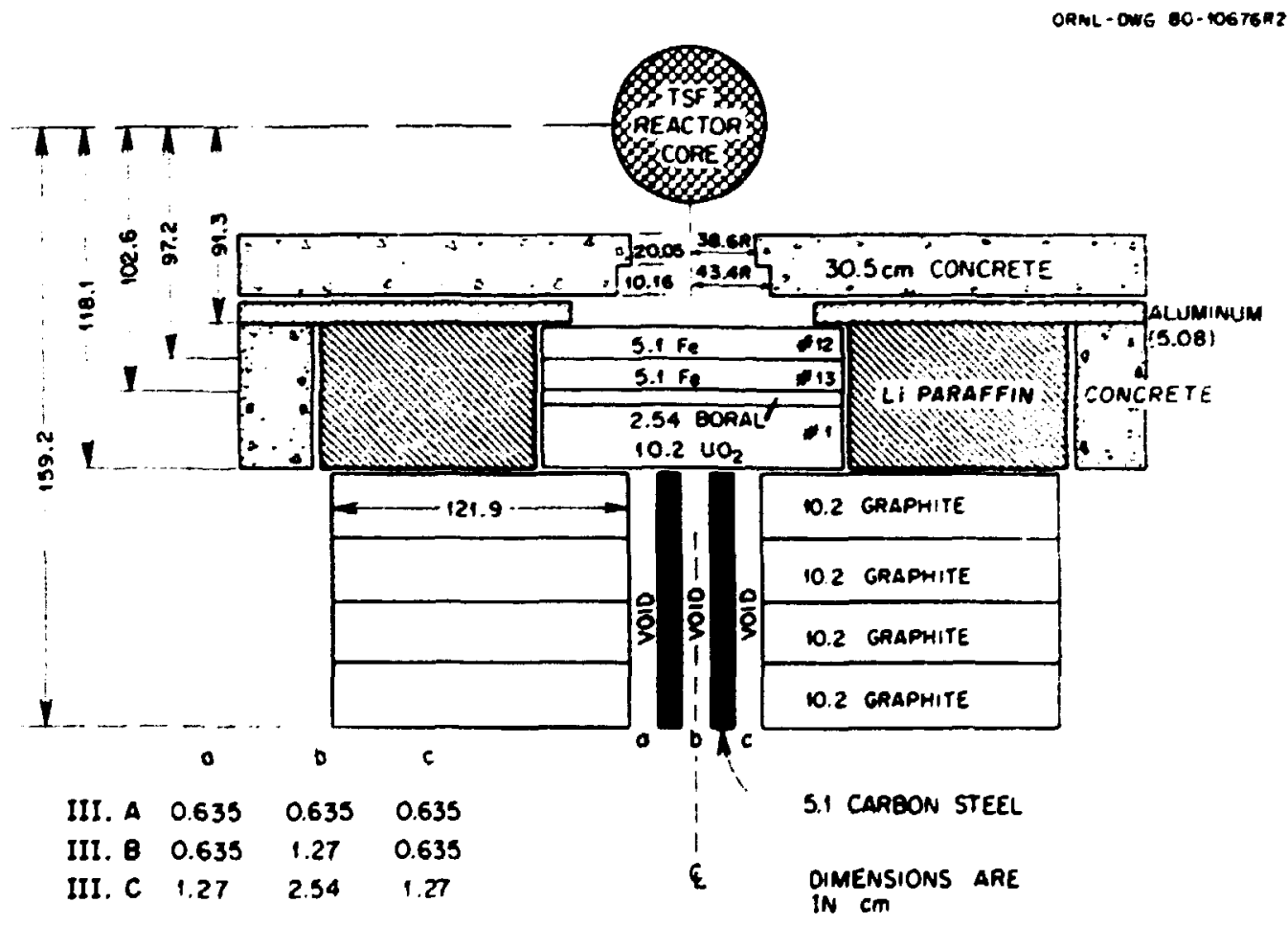

FIg. 9.5. Mockup of Outer Radial Shleld with Iron LIners and Three SIlts: ContIgurations III.A - III.C. 
ORAL-PHOTO 2944-80

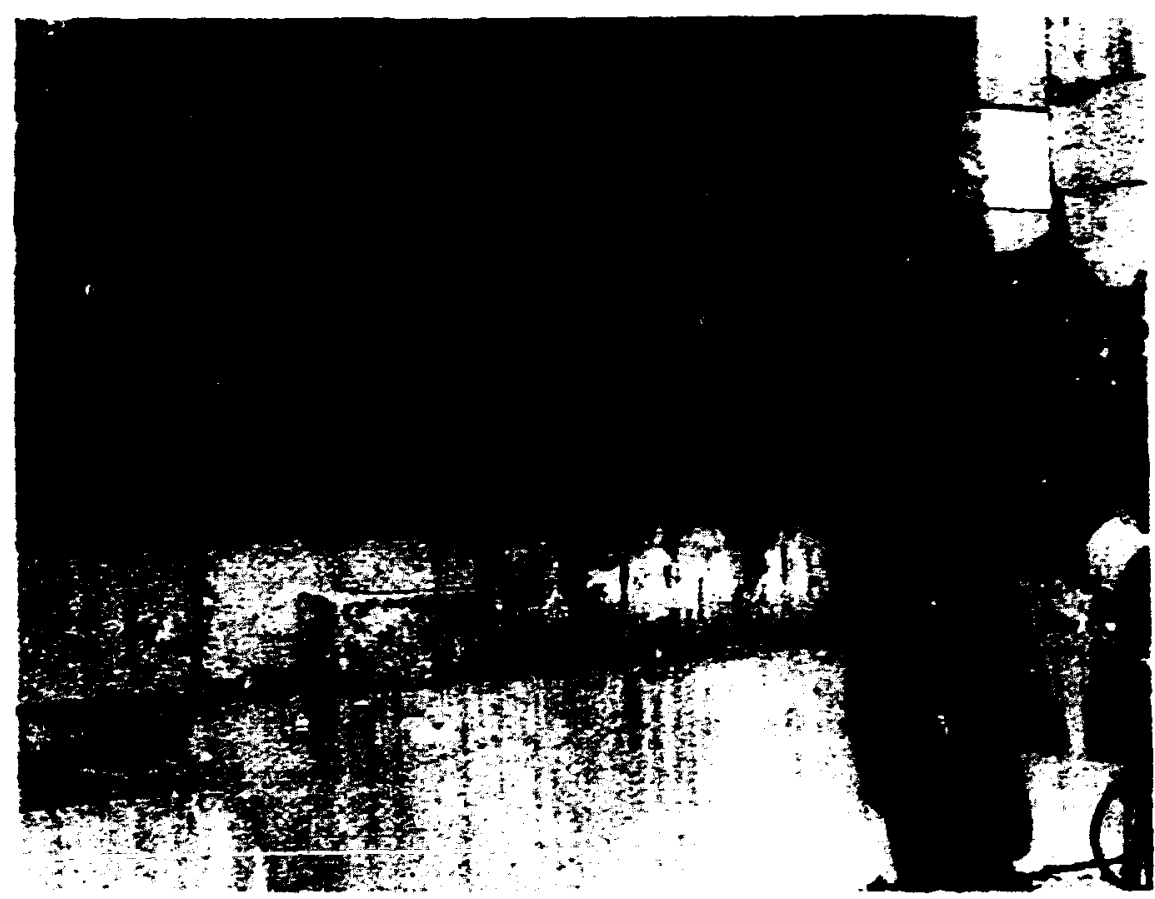

Fig. 9.6. Typlcal Mockup of Graphite Shleld with Iron Liners - Three SIIts: Configurations $\| 11 . A, I I 1.8$, III.C.

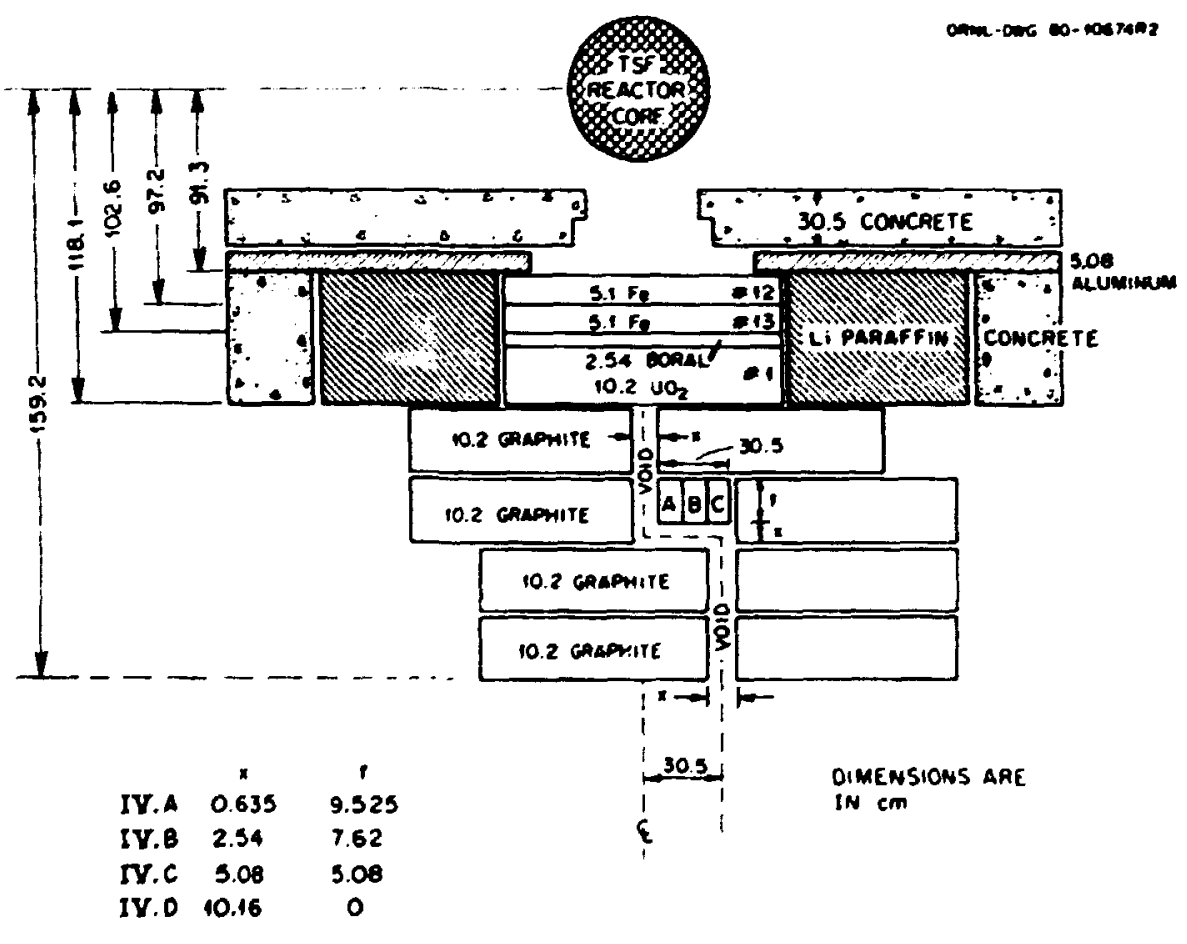

A, B, C ARE $10.16 \mathrm{~cm}$ WIOE GAAPHITE

Fig. 9.7. Mockup of Outer Radial Shleld with Single Unlined Stoppod SIItz Conflgurations IV.A - IV.D. 
$\operatorname{leg}$ was $20.3 \mathrm{~cm}$ minus one-half of the silt width and the length of the third leg was 20.3 ca plus onemalf of the slit width. In all cases the sam slit width was waintalned in all three legs $(0.635,2.54,5.08$, or $10.16 \mathrm{~cm})$, end, as was the case for Conf Igurations 1. 20.3-ca thicknesses of graphlte were offset at the top and bottan of the mockup.

It wll be noted that each configuration is preceded by a spertru modifler corsisting of $10.2 \mathrm{~cm}$ of Iron, $2.54 \mathrm{~cm}$ of boral, and $10.2 \mathrm{~cm}$ of $\mathrm{WO}_{2}$ surrounded by IIthiated paraffin. Preanalysis calculations had shown that this arrangenent of materials would convert the energy spectru of the TSR-II bean to a spectrun typical of that Incident on the GCFR outer radial shield. (Note: The $\mathrm{NO}_{2}$ "slab" Is the sane slab described on page 8-9 In Section 8.)

\subsection{MEASURED RESULTS}

The exper Iment began with measurements behind the spectrum nodifler. However, because agreement between measurements and calculations for siallar spectrum modiflers had repeatediy verifled the analytical methods for such conflgurations, and because the experiment was to be abbrevlated, the measureaents vere IImited to 2-, 5-, and 10-In. Bonner ball measurements at two centerline locations behind the spectrum modifler. Measurements beyond the silt configurations were also IImited to the three Bonner ball detectors plus the Hornyak button. Horlzontal traverse masurements were made with the Hornyzk button and the 2-in. Bonner ball directiy behind all the configurations and with all the detectors at a distance of $30.5 \mathrm{~cm}$ beyond the conflgurations.

9.3.1. Measurements for Conflgurations I: Single Silts

As described above, the assembiles measured In the fIrst phase of the experiment consisted of a $40.8 \mathrm{mcm}$ thickness of graphite that was positioned behind a spectrum modifler and contained a single stralght silt (see Figs. 9.2 and 9.3). The conflgurations differed from one another in the sllt width, wth ceven different s' It wldths being measured. Thls phase of the experiment also Included centeriline measurcments behind the spectrum nodifler alone, the results of which ore shown In Table 9.1. 
Table 9.1. Masured Bonner Ball Responses on Ax/s 30.5 and $305 \mathrm{~cm}$ Beyond Spectrum Modifier (ConfIguretion I.A)

\begin{tabular}{ccc}
\hline & \multicolumn{2}{c}{ Response (counts/s-W) } \\
\cline { 2 - 3 } Bonner Ball & At $30.5 \mathrm{~cm}$ & At $305 \mathrm{~cm}$ \\
\hline $2-\mathrm{in}$. & $1.15 \times 10^{1}$ & $7.5 \times 10^{-1}$ \\
$5-\mathrm{in}$. & $9.60 \times 10^{3}$ & $3.809 \times 10^{2}$ \\
$10-\mathrm{in}$. & $4.61 \times 10^{3}$ & $1.996 \times 10^{2}$ \\
\hline
\end{tabular}

Measurements along radial traverses vere made thind each of the single-silt assemblles with the Hornyak button ot a distance of 1.6 and and the 2-In. Bonner bail at a distance cf $3 \mathrm{~cm}$. Additional measurements with the 2-in. Bonner ball vere rade behind two configurations at a distance of $6 \mathrm{~cm}$, and short radial traverses were made with both the 2-in. Bonner ball and the Hornyak button, as vell as with the 5-In. and 10-in. Bonner balls, at a distance of $30.5 \mathrm{~cm}$. The primary Intent at $30.5 \mathrm{~cm}$ was to obtaln centerline values, with the short traverses supporting the certerline measurnents.

The 2-in. iconner jall responses and the Hornyak button responses obtalned directiy behind the configurations are plotted in Figs. 9.8 and 9.9 respectively, and selected detector responses from all the traverses are shown in Tables 9.2 and 9.3 . It will be noted that the Hornyak button data are IImited to slit widths of 0 and $1.27 \mathrm{~cm}$. This Is because water becane trapped betweer. the graphite pleces during the experinent, negating most of the measurements, and the ramaining time was insufficlent to repeat all the measurements.

The curves in Fig. 9.8 all show a broad plateau across the slit, with relativeiy small differences between the varlous slit widths. Since the 2-In. Bonner bali is primarlly sensitive to low-energy neutrons, this Indicates that much of the low-energy flux is due to neutrons that penetrate through the graphite rather than through the slit. As would be expected, however, the Hornyak button measurements shown in FIg. 9.9 peak at the silt location, indicating considerable streming of high-energy neutrons through the sllt. The Hornyak button centerline flux for the $1.27-\mathrm{cm}$ sllt is higher by a factor of 2.8 than the centerline flux for the no-silt cas:. On the basis of the Hornyak button "wet graphite" data, which ore not included here but whlch do not differ greatiy from the "dry graphlte" data (see ref. 1), It appears that the increase in the fast-neutron flux would be bout a factor of 13 for the $10.2-\mathrm{cm} \mathrm{sllt}$. 


\subsubsection{Measurgents for Configurations 11: Iron-Lined Single SIIts}

Fr: Igurations II represented two abutting pleces of the radial sh?eld (graphite) in stalniess steel envelopes. Thus the point of interest was the inpact of the iron pieces on the nel ron streaning through the silt separating then. The slit wicths wasured $0,0.635$, $2 ?$, and $2.54 \mathrm{~cm}$.

Radia: t- averse measurements were made directly benind each of the four configirarlors with the 2-In. Bonner ball and with the Hornyak button. Radial traverse mosurenent, with the Hxrnyak button were also made at $30.5 \mathrm{ca}$, and near-centerline masurements ve: 9 made with the 2-, 5-, and $10-i n$. Bonner balls at $30.5 \mathrm{~cm}$. The results obtained dirertiy hahind the configurations are plotted if Figs. 9.10 and 9.11, and typlcal responses from all the measurements are given in Tables 9.0 and 9.5 .

Figure 9.10 shows a pronounced depression of the low-energy flux directiy behind the iron, with an increase in the neutron transmission at the slit position occurring only for the ridest slit $2.52 \mathrm{~cm}$ ). As shown in $\mathrm{FIg} .9 .1$, the high-energy $\mathrm{flux}$ is also depressed behind the Iron relative to the flux behinc the graphite; hovever. In all cases It peaks sharply at the position of the slit, again indicating the streaning of fast neutrons through the slits.

\subsubsection{Measurements for Configurations III: Three-SIit Assemblles}

The measurements behind Configurations III, which had s! its between the two iron liners and also between the lros. and grapnite, were made at the same locations as those behind Configurations 11 . The results are given in Figs. 9.12 and 9.13 and in Tables 9.6 and 9.7 .

The shapes and magnitudes of the curves shown in Fig. 9.12 for the 2-in. Bonner ball measurements directly behind the configurations are very similar to those shown in FIg. 9.10. That is, the low-energy flux is significantly depressed behind the iron and the values of the slight peaks at the centerline are approximately equal for the same silt vidths. No peaking of the flux occurs opposite the two outer silts of Configuratlons III; however, the curves do rise more sherply near the Iron-graphlte Interfeces than do the curves for Conflgurations 11 . 
Table 9.2. Masured Bonner Ball Responses Along Radial Traverses Beyoid Configurations 1 (Single Silt Through Graphite)

\begin{tabular}{|c|c|c|c|c|c|c|c|c|}
\hline \multirow[b]{2}{*}{$\begin{array}{c}\text { Bonner } \\
\text { Ball }\end{array}$} & \multirow{2}{*}{$\begin{array}{l}\text { Distance } \\
\text { from Axis } \\
\text { (an? }\end{array}$} & \multicolumn{7}{|c|}{ Response $(\text { counts/s. } w)^{\circ}$} \\
\hline & & $\begin{array}{c}1 . \mathrm{B} \\
0.635 \mathrm{~cm} \\
\end{array}$ & $\begin{array}{l}1 . C \\
1.27 \mathrm{co}\end{array}$ & $\begin{array}{l}1.0 \\
2.54\end{array}$ & $\begin{array}{r}\text { I.E. } \\
5.08 \mathrm{~cm}\end{array}$ & $\begin{array}{c}\text { I.F. } \\
7.62 \mathrm{c}\end{array}$ & $\begin{array}{l}I . G \\
10.16 \mathrm{~cm} \\
\end{array}$ & $\begin{array}{l}1 . \mathrm{H}, \\
0 \mathrm{cos}\end{array}$ \\
\hline \multicolumn{9}{|c|}{$3 \mathrm{~cm}$ Bevond Canfiguration } \\
\hline $2-\ln$ & $\begin{array}{l}20 \\
10 \\
5 \\
2.5 \\
0\end{array}$ & $\begin{array}{l}8.03(1)^{b} \\
8.82(1) \\
8.99(1) \\
9.37(1) \\
9.78(1)\end{array}$ & $\begin{array}{c}7.99(1) \\
8.84(1) \\
9.44(1) \\
- \\
1.05(2)\end{array}$ & $\begin{array}{c}0.25(1) \\
9.46(1) \\
1.06(2) \\
- \\
1.35(2)\end{array}$ & $\begin{array}{c}8.52(1) \\
1.02(2) \\
1.29(2) \\
- \\
1.64(2)\end{array}$ & $\begin{array}{c}8.64(1) \\
1.09(2) \\
1.48(2) \\
- \\
1.75(2)\end{array}$ & $\begin{array}{c}8.81 i j j \\
1.15(2) \\
1.59(2) \\
-\overline{7 \epsilon}(2)\end{array}$ & $\begin{array}{c}7.76(1) \\
8.44(1) \\
8.53(1) \\
-\overline{54}(i)\end{array}$ \\
\hline \multicolumn{9}{|c|}{6 an Deyond Configuration } \\
\hline $2-i n$ & $\begin{array}{r}20 \\
10 \\
5 \\
0 \\
\end{array}$ & $\bar{z}$ & $=$ & $\overline{-}$ & $\bar{z}$ & $\overline{-}$ & $\begin{array}{l}8.59(1) \\
1.17(2 ! \\
1.39(2) \\
1.48(2) \\
\end{array}$ & $\begin{array}{l}7.18(1) \\
7.74(1) \\
3.01(1) \\
.93(1) \\
\end{array}$ \\
\hline \multicolumn{9}{|c|}{$30.5 \mathrm{~cm}$ Eeyond Conflguration } \\
\hline $2-i n$ & $\begin{array}{l}5 \\
2.5 \\
0\end{array}$ & $\begin{array}{l}5.06(1) \\
5.13(1) \\
5.14(1)\end{array}$ & $\begin{array}{l}5.07(1) \\
5.25(1) \\
5.27(1)\end{array}$ & - & $\begin{array}{l}6.27(1) \\
6.26(1) \\
6.27(1)\end{array}$ & $\begin{array}{l}6.53(1) \\
6 . \overline{47(1)}\end{array}$ & $\begin{array}{l}6.59(1) \\
6.67(1) \\
6.65(1)\end{array}$ & $\begin{array}{c}4.82(1) \\
4.89(1)\end{array}$ \\
\hline $5-\ln$. & $\begin{array}{l}5 \\
2.5 \\
0\end{array}$ & $\begin{array}{l}6.95(2) \\
7.14(2) \\
7.20(2)\end{array}$ & $\begin{array}{l}- \\
- \\
-\end{array}$ & $\begin{array}{l}9.43(2) \\
1.04(3) \\
1.06(3)\end{array}$ & $\begin{array}{l}1.43(3) \\
1.53(3) \\
1.58(3)\end{array}$ & $\begin{array}{l}1.89(3) \\
2.00(3) \\
2.08(3)\end{array}$ & $\begin{array}{l}2.31(3) \\
2 . \overline{44} 3)\end{array}$ & $\begin{array}{l}6.41(2) \\
6.44(2)\end{array}$ \\
\hline $10-\ln$ & $\begin{array}{l}5 \\
2.5 \\
0\end{array}$ & $\begin{array}{l}1.50(2) \\
1.52(2) \\
1.53(2)\end{array}$ & $\begin{array}{l}1.65(2) \\
1.69(2) \\
1.68(2)\end{array}$ & $\begin{array}{l}2.29(2) \\
2.42(2) \\
2.43(2)\end{array}$ & $\begin{array}{l}3.93(2) \\
4.21(2) \\
4.37(2)\end{array}$ & $\begin{array}{l}5.68(2) \\
5.94(2) \\
6.11(2)\end{array}$ & $\begin{array}{l}7.52(2) \\
\overline{8.06(2)}\end{array}$ & $\begin{array}{l}1.36(2) \\
1 . \overline{34(2)}\end{array}$ \\
\hline
\end{tabular}

aesponses are argrages of measurements at equidi, tances from the axis.

Dead: $8.06 \times 10^{i}$.

Comparing the Hornyak button Traverses of Fig. 9.13 with those in Fig. 9.11 shows that the high-energy centerline fIuxes in Configurations II and III also are approximately the same for the same slit widths. However, in this case the presence of the outer slits results in additional neutron streaning through the con!lgurations. (The lack of syminetry in the dato for the cuter volds could be due to several things: slight differences in vold withs, in detector location, etc.) 
Table 9.3. Masured Hornyak Button Responses Beyond Configurations 1 (Single Slit Through Graphite)

\begin{tabular}{|c|c|c|}
\hline \multirow{2}{*}{$\begin{array}{l}\text { Distance } \\
\text { from Nxis } \\
\text { (ca) }\end{array}$} & \multicolumn{2}{|c|}{ Dose Rate $(\operatorname{args} / g \cdot s-k w)^{a}$} \\
\hline & $\begin{array}{l}1 . \mathrm{C} \\
1.27 \mathrm{~cm}\end{array}$ & $\begin{array}{l}1 . H . \\
0.0\end{array}$ \\
\hline \multicolumn{3}{|c|}{1.6 can Beyond Cont iguration } \\
\hline $\begin{array}{l}20 \\
10 \\
5 \\
2 \\
0.5 \\
0\end{array}$ & $\begin{array}{l}1.62(-2)^{b} \\
1.82(-2) \\
2.00(-2) \\
2.23(-2) \\
3.67(-2) \\
3.81(-2)\end{array}$ & $\begin{array}{l}1.25(-3) \\
1.31(-2) \\
1.35(-2) \\
- \\
-\overline{36}(-2)\end{array}$ \\
\hline \multicolumn{3}{|c|}{$30.5 \mathrm{~cm}$ Beyond Configuration } \\
\hline $\begin{array}{l}20 \\
10 \\
5 \\
2 \\
0.5 \\
0\end{array}$ & $\begin{array}{l}9.78(-3) \\
1.05(-2) \\
1.11(-2) \\
1.30(-2) \\
1.58(-2) \\
1.67(-2)\end{array}$ & $\begin{array}{c}\overline{\overline{8} 2}(-3) \\
9.92(-3) \\
\overline{-} \\
1 . \overline{01}(-2)\end{array}$ \\
\hline
\end{tabular}

aresponses are averages of measurements at equidistances from the axis. $D_{\text {Reac: }} 1.62 \times 10^{-2}$.

\subsubsection{Measuremerts for Corfigurdtions liv: Ott set slits}

The measuremens beyonc the stepped slits of Contigurations iv were made ulth the same detectro at the same cistances ceyone tr.e experimental assemolles as in Contiguraticns 11 and 111 . Ir. Contigurations IV, nowever, the raclal traverses were referenced trom the centeriine of the exit slit and not tran the centerline of the reactor bean. The results of these measurements are snown in Figs. 9.14 and 9.15 and in Tebles 9.8 and 9.9 .

in woth Fig. 9.14 and 9.15 the peaks in the curves at the exit silt position are rother brood, indicating thot necitons are scotterling ogainst the vall: of the slit and exiting in vorlous directions. The brosdening increases with increasing si: width, with the right sides of the curves falling raplaly as the distance from the ixit silt increases. By contrast, the left sloes of the curves tend to level oft. -ith anly the 


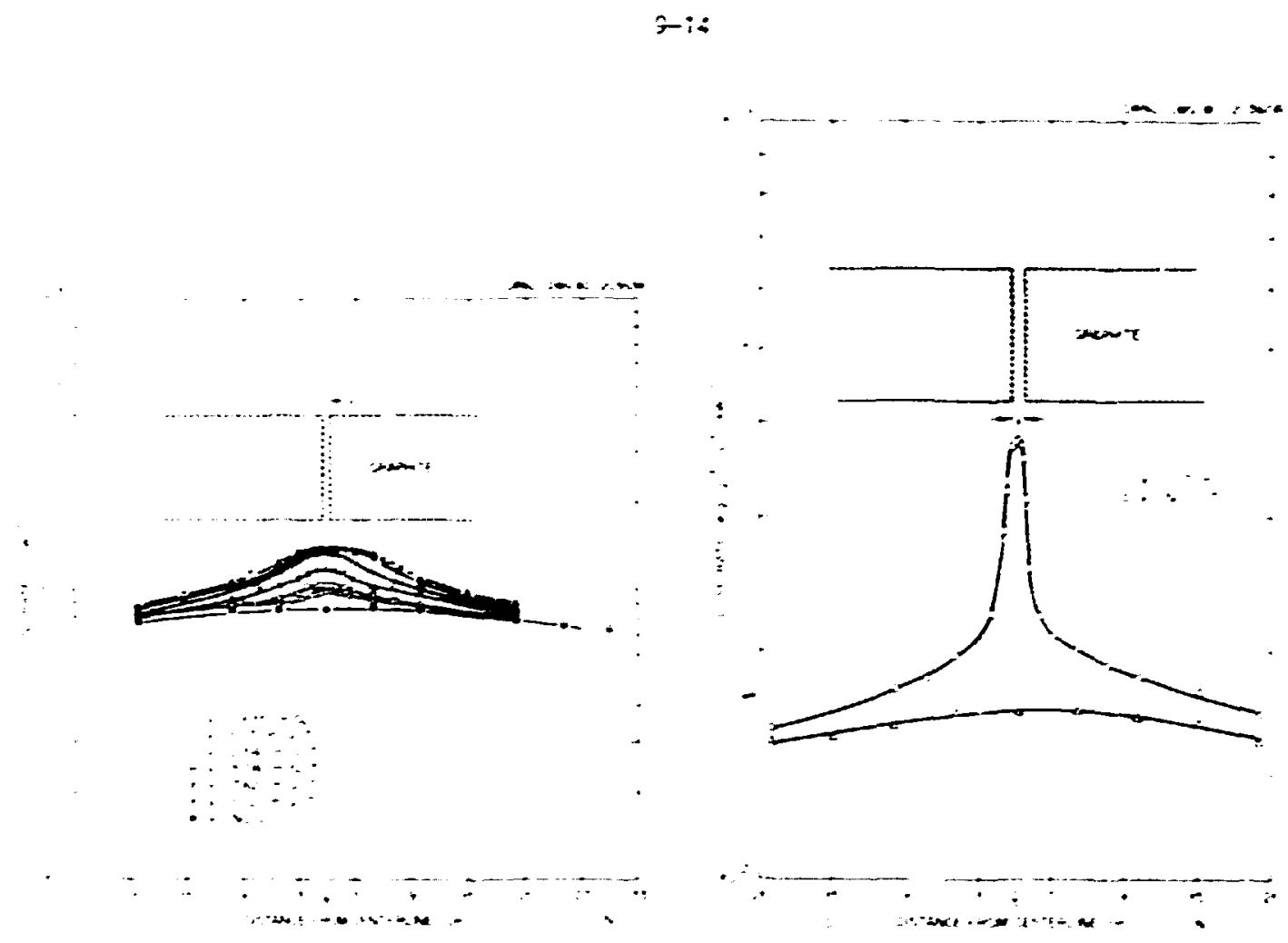

=i3. 7.6. Measurec 2-in. Eonner Ball Peszorses Jirectiy Behind Singlo-slit Asserelies (Sont iguraticns $1 . B-1 . H)$.
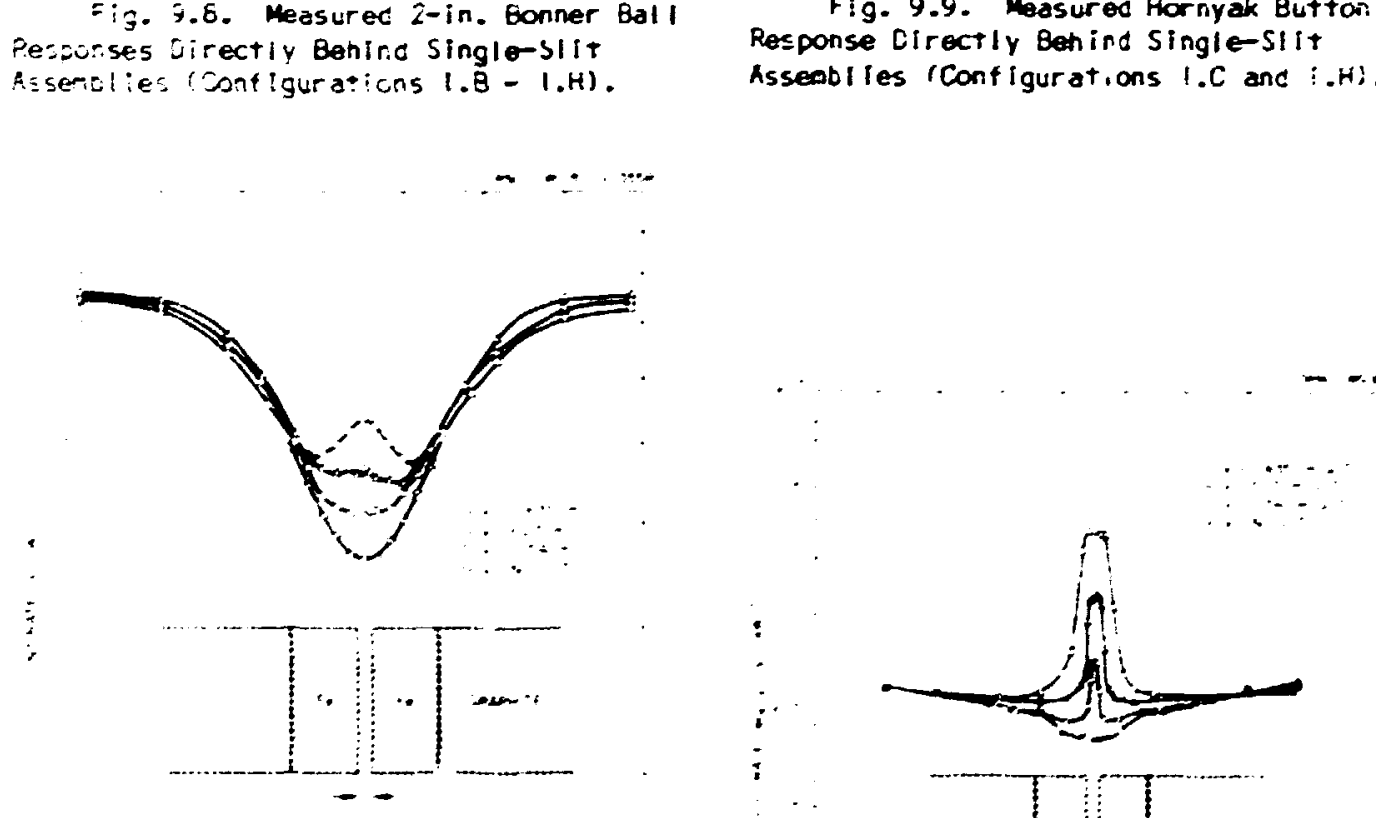

Asseablles rconfigurat.ons I.C and I.H:.

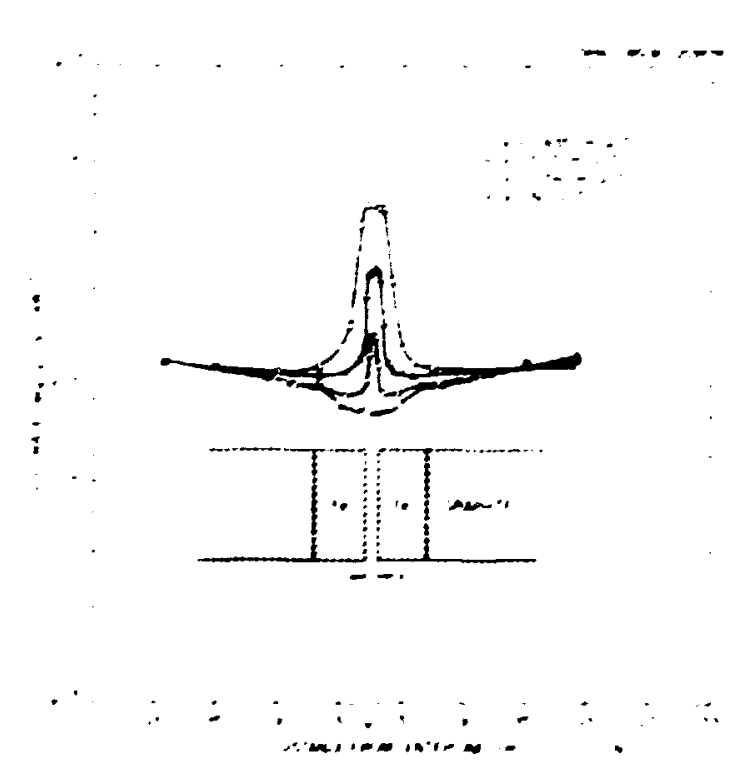

Flg. 9.10. Masured 2-in. Bonner Boll Pesponses Directly Bahind Iron-Lined SingleSll Assemel les (Contlguratlons $11 . A-11.0$ ).

Fig. 9.11. Masured Horniak Button Responses Directly BenInd Iron-L ined SingloS11t Asseacilios (Cont Igurarions $11 . A-11.0$ ). 


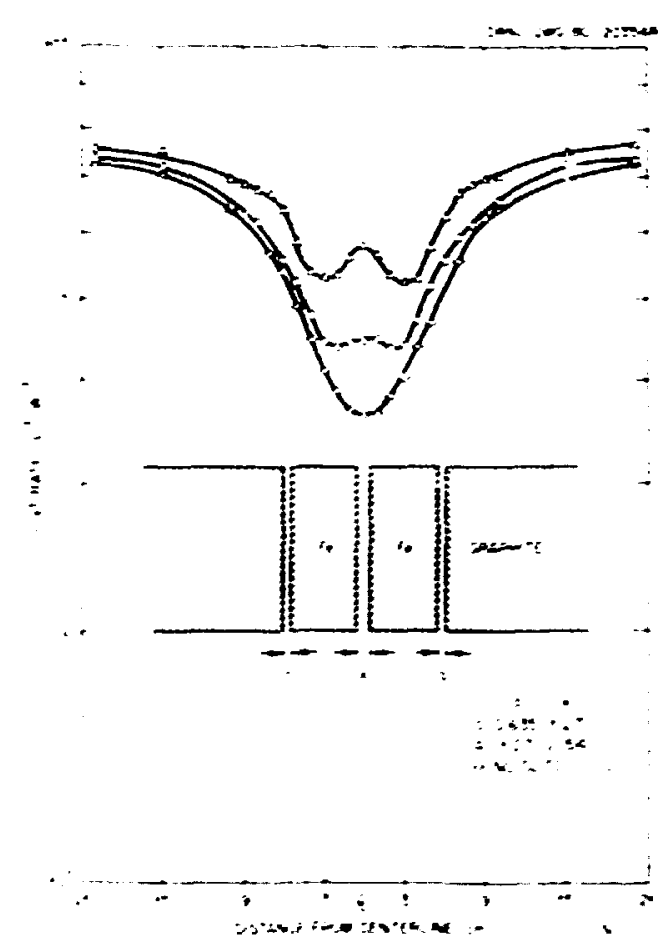

Fig. 9.12. Heasured 2-in. Bonner Eall Responses CIrectly Behind Three-Slit issentlies (Configurations III.E ane 111. . Comparec with 11.0 ).

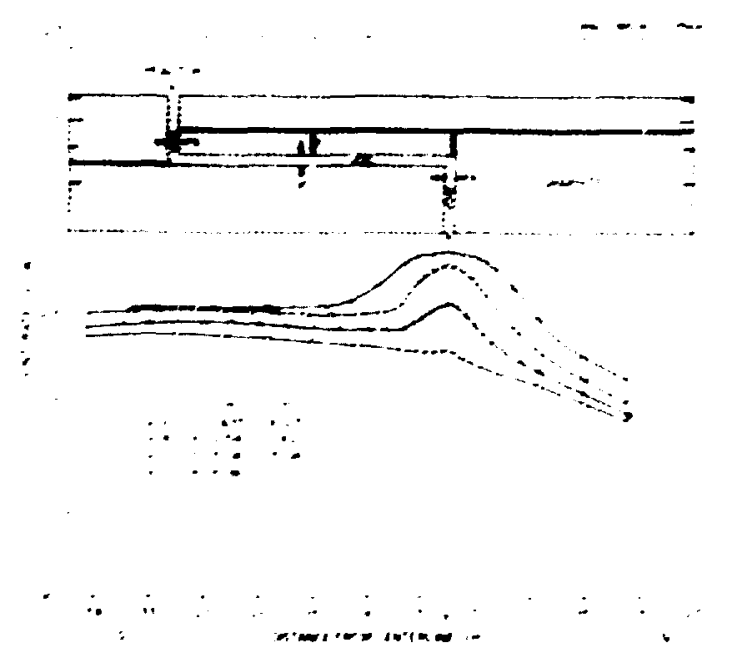

Fig. 9.14. Masured 2-in. Bonner Ball Fesconses Directly Bahind Stepped-sIIt Assemblles (Conf Igurations IY.A - IY.O).

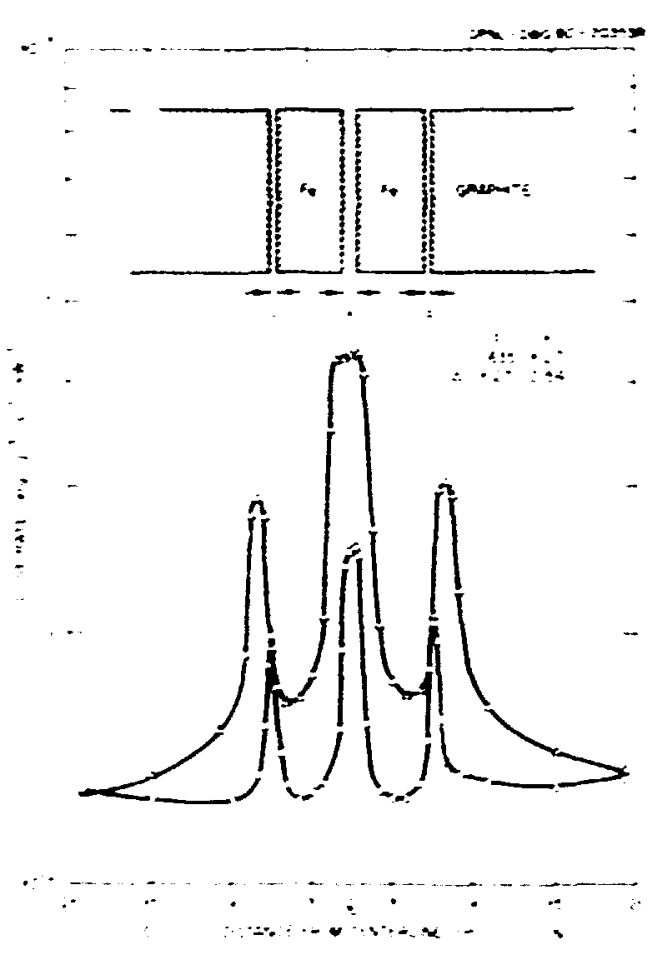

FIg. 9.13. Measured Hornyak Euttor. Responses Lirectly Betind Three-jlit Assemblies (Configurations $11: .8$ and $111 . C)$.

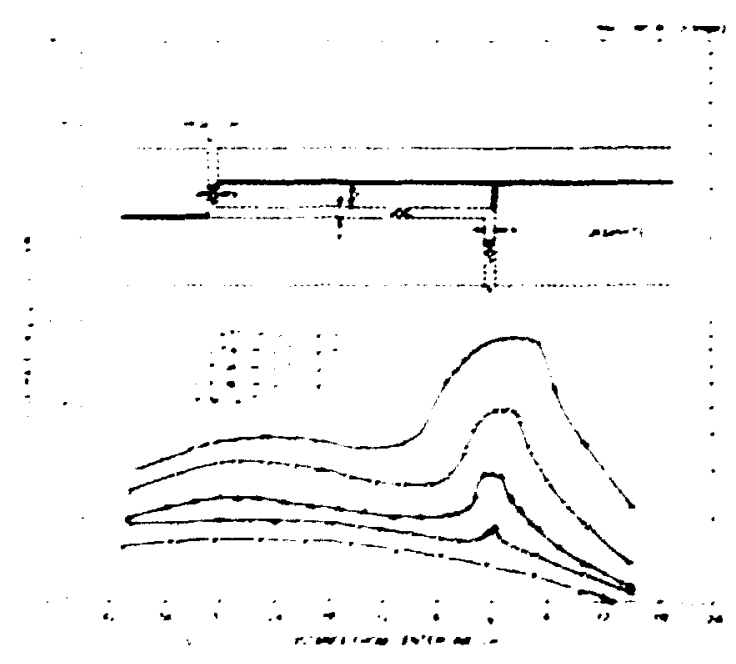

Fig. 9.15. Masured Hornyał Button Responses Directiy Behlnd Stepped-sIlt Assembiliss (Contigurations IV.A - IV.D). 
Table 9.4. Masured Bonner Ball Responses Beyond Conflgurations II (Iron-Lined Single Silt Through Graphite)

\begin{tabular}{|c|c|c|c|c|c|}
\hline \multirow[b]{2}{*}{$\begin{array}{l}\text { Boniner } \\
\text { Ball }\end{array}$} & \multirow{2}{*}{$\begin{array}{l}\text { Distance } \\
\text { from Axis } \\
\text { (c) }\end{array}$} & \multicolumn{4}{|c|}{ Response $(\text { counts/s-y })^{a}$} \\
\hline & & $\begin{array}{c}11 . \mathrm{A}, \\
0.635 \mathrm{~cm}\end{array}$ & $\begin{array}{l}11.8, \\
1.27 \mathrm{cos}\end{array}$ & $\begin{array}{l}11 . \mathrm{C} \text {, } \\
2.54 \mathrm{~cm}\end{array}$ & $\begin{array}{l}11.0 \\
0 \mathrm{com}\end{array}$ \\
\hline \multicolumn{6}{|c|}{$3 \mathrm{~cm}$ Beyond Configur ation } \\
\hline $2-\ln$ & $\begin{array}{r}20 \\
10 \\
5 \\
2 \\
0\end{array}$ & $\begin{array}{l}7.36(1)^{b} \\
6.44(1) \\
4.92 i 1) \\
4.19(1) \\
4.08(1)\end{array}$ & $\begin{array}{l}7.54(1) \\
6.69(1) \\
4.98(1) \\
4.56(i) \\
4.72(1)\end{array}$ & $\begin{array}{l}7.31(1) \\
6.34(1) \\
4.92(1) \\
4.98(1) \\
5.35(1)\end{array}$ & $\begin{array}{l}7.25(1) \\
6.38(1) \\
4.78(1) \\
3.85(1) \\
3.62(1)\end{array}$ \\
\hline \multicolumn{6}{|c|}{$30.5 \mathrm{~cm}$ Beyond Conflguration } \\
\hline $2-i n$ & $\begin{array}{l}5 \\
2 \\
0\end{array}$ & $\begin{array}{l}3.89(1) \\
3.89(1) \\
3.95(1)\end{array}$ & $\begin{array}{l}3.90(1) \\
3.94(1) \\
4.02(1)\end{array}$ & $\begin{array}{l}4.03(1) \\
4.09(1) \\
4.05(1)\end{array}$ & $\begin{array}{l}3.77(1) \\
3.76(1) \\
3.73(1)\end{array}$ \\
\hline $5-\ln$. & $\begin{array}{l}5 \\
2 \\
0\end{array}$ & $\begin{array}{l}7.18(2) \\
7.32(2) \\
7.32(2)\end{array}$ & $\begin{array}{l}7.87(2) \\
8.24(2) \\
8.36(2)\end{array}$ & $\begin{array}{l}9.46(2) \\
1.02(3) \\
1.03(3)\end{array}$ & $\begin{array}{l}6.79(2) \\
6.81(2) \\
6.66(2)\end{array}$ \\
\hline 10-in. & $\begin{array}{l}5 \\
2 \\
0\end{array}$ & $\begin{array}{l}1.69(2) \\
1.72(2) \\
1.72(2)\end{array}$ & $\begin{array}{l}1.90(2) \\
1.94(2) \\
1.94(2)\end{array}$ & $\begin{array}{l}2.49(2) \\
2.58(2) \\
2.64(2)\end{array}$ & $\begin{array}{l}1.53(2) \\
1.56(2) \\
1.55(2)\end{array}$ \\
\hline
\end{tabular}

a Responses are averages of masurements of equldistances from the axis.

${ }^{\text {Read }: ~} 7.36 \times 10^{\prime}$.

high-energy flukes in Fig. 9.15 showling a slight increase opposite the entry silt. This indicetes that neutron Interactions with in the graphite negate the effect of neutrons directed oituard from the entry slit.

\subsection{COMPARISON OF MEASURED ANO CALCULATED RESULTS}

As noted earller, the suspension of the U.S. GCFR progrem precluded a complete analysis of the experiment. However, some calculatlons were performed with both the dIscrete ordinates code DOT and the Monte Carlo code MORSE for selected locations of the 2- and 3-In. Bonner balls beyond the conflgurations. Typlcal results are compared with the corrasponding masurements in Tables 9.10 and 9.11 . 
Table 9.5. Measured Hornyak Button Responses Beyond Conflgurations II (Iron-Lined Single Silt Through Graphite)

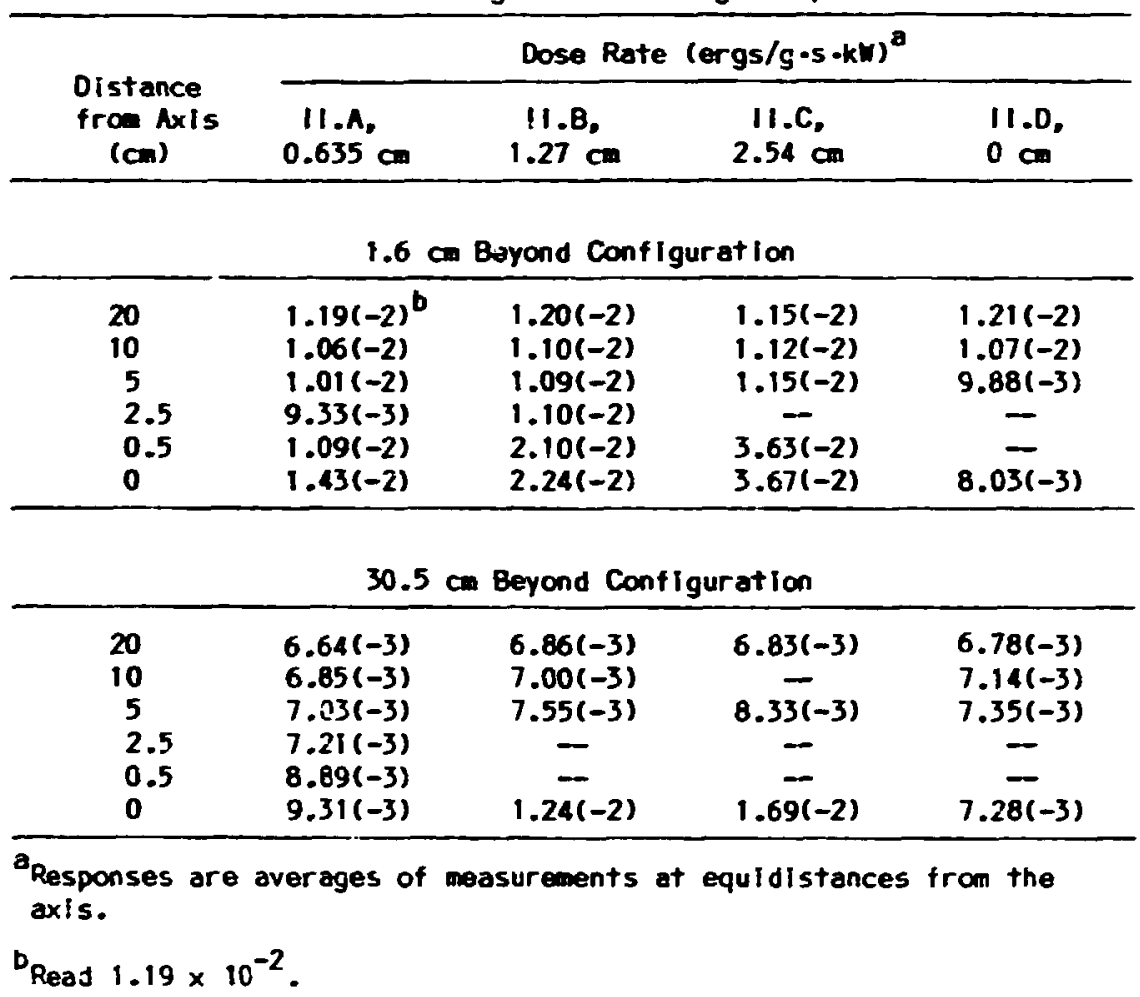

The DOT results and the measurements agree with in 208, wth some notable exceptions; In particular, the calculations yleld significantly higher results for the Iron-lined stralght slit (Conflguration II). In general, the MDRSE results and the measured results ore In poor agreement, but the curtallment of the GCFR progran did not permit a detalled investigation of the reasons why.

\subsection{REFERENCE}

1. F. J. Muckenthaler, J. L. Hull, and J. J. Mznning, "GCFR Plenum Shleld Design Shleld Heterogenelty Experiment," ORNL/TM-7714 (May 1981). 
Table 9.6. Measured Bonner Ball Responses Beyond Configurations III (Threa-SIIt Assemblies)

\begin{tabular}{|c|c|c|c|c|c|c|}
\hline \multirow[b]{2}{*}{$\begin{array}{c}\text { Bonner } \\
\text { Ball }\end{array}$} & \multirow{2}{*}{$\begin{array}{l}\text { Distance } \\
\text { from Axis } \\
\text { (a) }\end{array}$} & \multicolumn{5}{|c|}{ Response $($ counts/s-U) } \\
\hline & & $0.635 \mathrm{~cm}, 1.27 \mathrm{~cm}$ & $0.635 \mathrm{cos}$ & 1.27 & 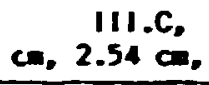 & $1.27 \mathrm{c}$ \\
\hline \multicolumn{7}{|c|}{$3 \mathrm{~cm}$ Beyond Configuration } \\
\hline $2-\ln$ & $\begin{array}{r}20 \\
10 \\
5 \\
2 \\
0\end{array}$ & $\begin{array}{l}7.35(1)^{b} \\
6.48(1) \\
5.20(1) \\
4.37(1) \\
4.44(1)\end{array}$ & & & $\begin{array}{l}7.61(1) \\
6.97(1) \\
5.78(1) \\
5.34(1) \\
5.78(1)\end{array}$ & \\
\hline \multicolumn{7}{|c|}{$30.5 \mathrm{~cm}$ Beyond Conf iguration } \\
\hline $2-$ in. & $\begin{array}{l}5 \\
2 \\
0\end{array}$ & $\begin{array}{l}3.94(1) \\
4.02(1) \\
4.03(1)\end{array}$ & & & $\begin{array}{c}4.37(1) \\
4.41(1) \\
-\end{array}$ & \\
\hline 5-in. & $\begin{array}{l}5 \\
2.5 \\
0\end{array}$ & $\frac{-}{8.81(2)}$ & & & $\begin{array}{l}1.16(3) \\
1.20(3) \\
1.18(3)\end{array}$ & \\
\hline 10-in. & $\begin{array}{l}5 \\
2.5 \\
0\end{array}$ & $\begin{array}{c}2.07(2) \\
2.13(2)\end{array}$ & & & $\begin{array}{l}3.08(2) \\
3.16(2) \\
3.17(2)\end{array}$ & \\
\hline
\end{tabular}

OResponses are averages of measurements at equidistances tron the axis.

'Dead: $7.35 \times 10^{1}$. 
Table 9.7. Measured Hornyak Button Responses Beyond Configurations III (Three-SIIt Assemblies)

\begin{tabular}{|c|c|c|c|c|c|}
\hline \multirow{2}{*}{$\begin{array}{l}\text { Distance } \\
\text { from Axis } \\
\text { (con) }\end{array}$} & \multicolumn{5}{|c|}{ - Dose Rate (ergs/g-s/kW) } \\
\hline & $0.635 \mathrm{~cm}$, & $\begin{array}{l}1: 1 . \mathrm{B}, \\
1.27 \mathrm{~cm}, 0.635 \mathrm{~cm}\end{array}$ & $1.27 \mathrm{~cm}$, & $\begin{array}{l}111 . C, \\
2.54 \mathrm{~cm},\end{array}$ & $1.27 \mathrm{~cm}$ \\
\hline
\end{tabular}

\begin{tabular}{rll}
\multicolumn{3}{c}{$1.6 \mathrm{~cm}$ Beyond Configuration } \\
\hline 20 & $1.30(-2)^{b}$ & $1.33(-2)$ \\
10 & $1.33(-2)$ & $1.58(-2)$ \\
5 & $1.32(-2)$ & $1.68(-2)$ \\
2 & $1.31(-2)$ & $2.06(-2)$ \\
0.5 & $2.45(-2)$ & $4.28(-2 !$ \\
0 & $2.58(-2)$ & $4.31(-2)$ \\
\hline
\end{tabular}

$30.5 \mathrm{~cm}$ Beyond Confliguration

\begin{tabular}{rll}
\hline 20 & $6.85(-3)$ & $8.99(-3)$ \\
10 & $7.36(-3)$ & $1.10(-2)$ \\
5 & $8.20(-3)$ & $1.27(-2)$ \\
2 & $0.61(-3)$ & $1.92(-2)$ \\
0.5 & $1.22(-2)$ & - \\
0 & $1.24(-2)$ & $2.16(-2)$ \\
\hline
\end{tabular}

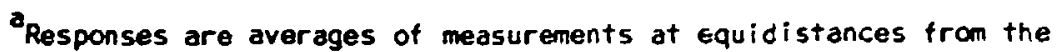
axis.

Beed: $1.30 \times 10^{2}$. 
Table 9.8. Measured Bonner Ball Responses Beyond Conflgurations IV (Stepped SIIt Asseablles)

\begin{tabular}{|c|c|c|c|c|c|c|}
\hline \multirow[b]{2}{*}{$\begin{array}{c}\text { Bonner } \\
\text { Ball }\end{array}$} & \multirow{2}{*}{$\begin{array}{l}\text { Distance } \\
\text { from ExIt } \\
\text { Slit AxIs } \\
\text { (ca) }\end{array}$} & \multicolumn{5}{|c|}{ Response (counts/s-W) } \\
\hline & & $\begin{array}{l}\mathrm{I} . \mathrm{H}{ }_{2}^{\mathrm{a}} \\
\mathrm{O} \mathrm{cm}\end{array}$ & $\begin{array}{l}\text { IV.A, } \\
0.635 \mathrm{~cm}\end{array}$ & $\begin{array}{l}\text { IV.B, } \\
2.54 \mathrm{ca}\end{array}$ & $\begin{array}{c}\text { IV.C, } \\
5.08 \mathrm{~cm}\end{array}$ & $\begin{array}{l}\text { IV.D, } \\
10.2 \mathrm{~cm}\end{array}$ \\
\hline \multicolumn{7}{|c|}{$3 \mathrm{~cm}$ Beyond Configuration } \\
\hline $2-i n$ & $\begin{array}{l}20 N \\
10 N \\
5 N \\
2 N \\
0 \\
2 S \\
5 S \\
10 S \\
20 S\end{array}$ & $\begin{array}{c}4.35(1)^{b} \\
5.70(1) \\
6.31(1) \\
-\overline{75}(1) \\
-\overline{4}(1) \\
7.43(1) \\
7.79(1) \\
8.42(1)\end{array}$ & $\begin{array}{l}4.34(1) \\
5.81(1) \\
6.45(1) \\
7.1^{+}(1) \\
7.63(1) \\
7.57(1) \\
7.62(1) \\
7.99(1) \\
8.44(1)\end{array}$ & $\begin{array}{c}4.58(1) \\
6.55(1) \\
8.08(1) \\
1.01(2) \\
1.13(2) \\
1.05(2) \\
9.21(1) \\
= \\
-\end{array}$ & $\begin{array}{c}5.02(1) \\
7.63(1) \\
1.10(2) \\
1.44(2) \\
1.54(2) \\
1.45(2) \\
1.15(2) \\
1.04(2) \\
-\end{array}$ & $\begin{array}{c}6.04(1) \\
9.99(1) \\
: .53(2) \\
1.67(2) \\
1.73(2) \\
1.68(2) \\
1.56(2) \\
1 . \overline{10(2)}\end{array}$ \\
\hline \multicolumn{7}{|c|}{$30.5 \mathrm{~cm}$ Beyond Configuration } \\
\hline $2-\ln$ & $\begin{array}{l}5 N \\
2.5 N \\
2 N \\
0 \\
2 S \\
2.5 S \\
5 S\end{array}$ & $\begin{array}{c}3.81(1) \\
-\overline{89}(1) \\
3.89(1) \\
4.03(1) \\
4.09(1) \\
\overline{4.27(1)}\end{array}$ & $\begin{array}{c}3.95(1) \\
4.12(1) \\
\overline{4} \\
4.27(1) \\
\overline{3.36}(1) \\
4.47(1)\end{array}$ & $\begin{array}{c}4.80(1) \\
- \\
5 . \overline{15}(1) \\
\overline{-} \\
5 . \overline{23}(1)\end{array}$ & $\begin{array}{c}5.80(1) \\
5.97(1) \\
\overline{6} \\
6.11(1) \\
\overline{6.23(1)} \\
6.34(1)\end{array}$ & $\begin{array}{l}- \\
\overline{-} \\
6.91(1) \\
- \\
-\end{array}$ \\
\hline $5-\ln$ & $\begin{array}{l}5 N \\
2.5 N \\
2 N \\
0 \\
2 S \\
2.5 S \\
5 S\end{array}$ & $\begin{array}{l}5.13(2) \\
-\overline{19}(2) \\
5.42(2) \\
5.51(2) \\
\overline{5.59(2)}\end{array}$ & $\begin{array}{c}5.33(2) \\
5.79(2) \\
- \\
5.92(2) \\
- \\
6.11(2) \\
6.01129\end{array}$ & $\begin{array}{c}7.23(2) \\
- \\
7.89(2) \\
= \\
8 . \overline{06}(2)\end{array}$ & $\begin{array}{c}1.04(3) \\
1.11(3) \\
\overline{1.09} \\
-\overline{1} \\
1 . \overline{16(3)}\end{array}$ & $\begin{array}{l}- \\
\overline{-} \\
1.85(3) \\
-- \\
--\end{array}$ \\
\hline 10-in. & $\begin{array}{l}5 \mathrm{~N} \\
2.5 \mathrm{~N} \\
2 \mathrm{~N} \\
0 \\
2 \mathrm{~S} \\
2.5 \mathrm{~S} \\
5 \mathrm{~S}\end{array}$ & $\begin{array}{l}1.05(2) \\
-\overline{11(2)} \\
1.12(2) \\
1.15(2) \\
1.20(2)\end{array}$ & $\begin{array}{l}1.13(2) \\
1.19(2) \\
\overline{1.21(2)} \\
-\overline{1.24(2)} \\
1.27(2)\end{array}$ & $\begin{array}{c}1.54(2) \\
= \\
1.68(2) \\
= \\
1.73(2)\end{array}$ & $\begin{array}{c}2.02(2) \\
2.18(2) \\
- \\
2.30(2) \\
-\overline{3} \\
2.39(2) \\
2.45(2)\end{array}$ & $\begin{array}{l}- \\
- \\
4.75(2) \\
- \\
- \\
-\end{array}$ \\
\hline
\end{tabular}

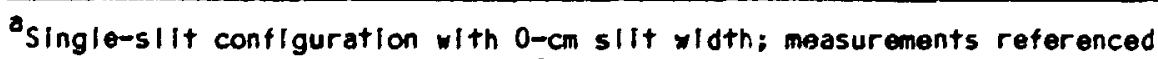
trom centerline of exit slit in Configurations iv.

Bead: $4.35 \times 10^{1}$. 
Table 9.9. Measured Hornyak Button Responses Beyond Configurations IV (Stepped SIit Assemblles)

\begin{tabular}{|c|c|c|c|c|}
\hline \multirow{2}{*}{$\begin{array}{c}\text { Distance } \\
\text { fram Exit } \\
\text { Si it Axis } \\
\text { (cm) }\end{array}$} & \multicolumn{4}{|c|}{ Dose Rate (ergs/g.s-kW) } \\
\hline & $\begin{array}{l}\text { IV.A, } \\
0.635 \mathrm{~cm}\end{array}$ & $\begin{array}{l}\text { IY.B, } \\
2.54 \mathrm{~cm}\end{array}$ & $\begin{array}{l}\text { IV.C } \\
5.08 \mathrm{~cm}\end{array}$ & $\begin{array}{l}\text { IV.D, } \\
11.2 \mathrm{~cm}\end{array}$ \\
\hline \multicolumn{5}{|c|}{$1.6 \mathrm{~cm}$ Beyond ConfIguration } \\
\hline $\begin{array}{c}20 N \\
10 N \\
5 N \\
2 N \\
0 \\
2 S \\
5 S \\
10 S \\
20 S\end{array}$ & $\begin{array}{l}9.06(-3)^{\circ} \\
1.25(-2) \\
1.46(-2) \\
1.62(-2) \\
1.82(-2) \\
1.66(-2) \\
= \\
=\end{array}$ & $\begin{array}{l}9.17(-3) \\
1.37(-2) \\
1.81(-2) \\
2.36(-2) \\
2.86(-2) \\
2.39(-2) \\
2.06(-2) \\
2.19(-2)\end{array}$ & $\begin{array}{l}1.07(-2) \\
1.88(-2) \\
3.03(-2) \\
4.83(-2) \\
4.78(-2) \\
4.19(-2) \\
2.81(-2) \\
2.64(-2) \\
-\end{array}$ & $\begin{array}{l}1.44(-2) \\
3.67(-2) \\
6.42(-2) \\
6.72(-2) \\
8.44(-2) \\
7.78(-2) \\
6.08(-2) \\
3.64(-2) \\
-\end{array}$ \\
\hline \multicolumn{5}{|c|}{$30.5 \mathrm{~cm}$ Beyond Configuration } \\
\hline $\begin{array}{c}20 N \\
10 N \\
5 N \\
2.5 N \\
2 N \\
0 \\
2.55 \\
5 S \\
10 S \\
20 S\end{array}$ & $\begin{array}{c}6.61(-3) \\
8.17(-3) \\
8.69(-3) \\
- \\
9 . \overline{64}(-3) \\
\overline{9} \\
9.78(-3) \\
1.02(-2) \\
1.08(-2)\end{array}$ & $\begin{array}{c}7.56(-3) \\
9.67(-3) \\
1.12(-2) \\
1.19(-2) \\
1.21(-2) \\
1.23(-2) \\
1.20(-2) \\
1.20(-2) \\
1.23(-2)\end{array}$ & $\begin{array}{l}1.03(-2) \\
1.51(-2) \\
1.71(-2) \\
1.80(-2) \\
1 . \overline{1.83(-2)} \\
1.80(-2) \\
1.76(-2) \\
1.64(-2) \\
1.60(-2)\end{array}$ & $\begin{array}{l}-\overline{78(-2)^{b}} \\
2.97(-2)^{c} \\
3.03(-2)^{d} \\
2.97(-2) \\
2.92(-2) \\
2.86(-2)^{d} \\
2.74(-2)^{c} \\
-0 \\
2.08(-2)^{e}\end{array}$ \\
\hline
\end{tabular}

${ }_{\text {Read: }} 9.06 \times 10^{-3}$.

${ }^{b}$ At $9 \mathrm{~cm}$.

CAt $6 \mathrm{~cm}$.

dAt $3 \mathrm{~cm}$.

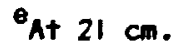


Table 9.10. Comparison of DOT-Calculated and Measured Bonner Ball Responses $30.5 \mathrm{~cm}$ Beyond Varlous Slit Conflgurations

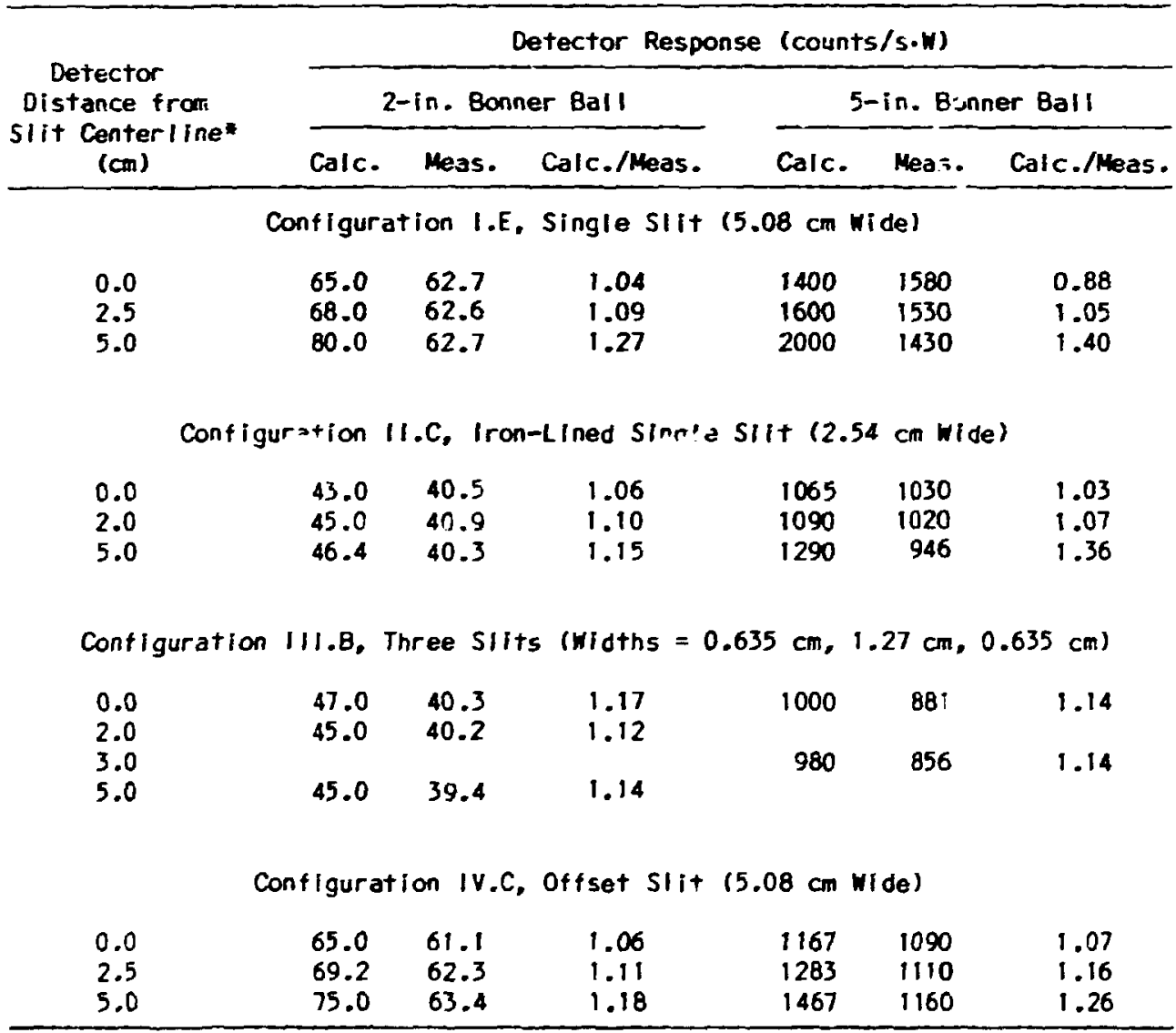

*For Configurations I.E, II.C, and III.B, sIIt centerline is in plane of reactor beam; for Configuration IV.C, the sIIt centerine is that of the exit silt, which is $30.5 \mathrm{~cm}$ from beam centerline. 
Trile 9.11. Comparison of MDRSE-Calculated and Measured Ecrirer Ea!: Responses $30.5 \mathrm{~cm}$ Beyond Various Slit Configurations

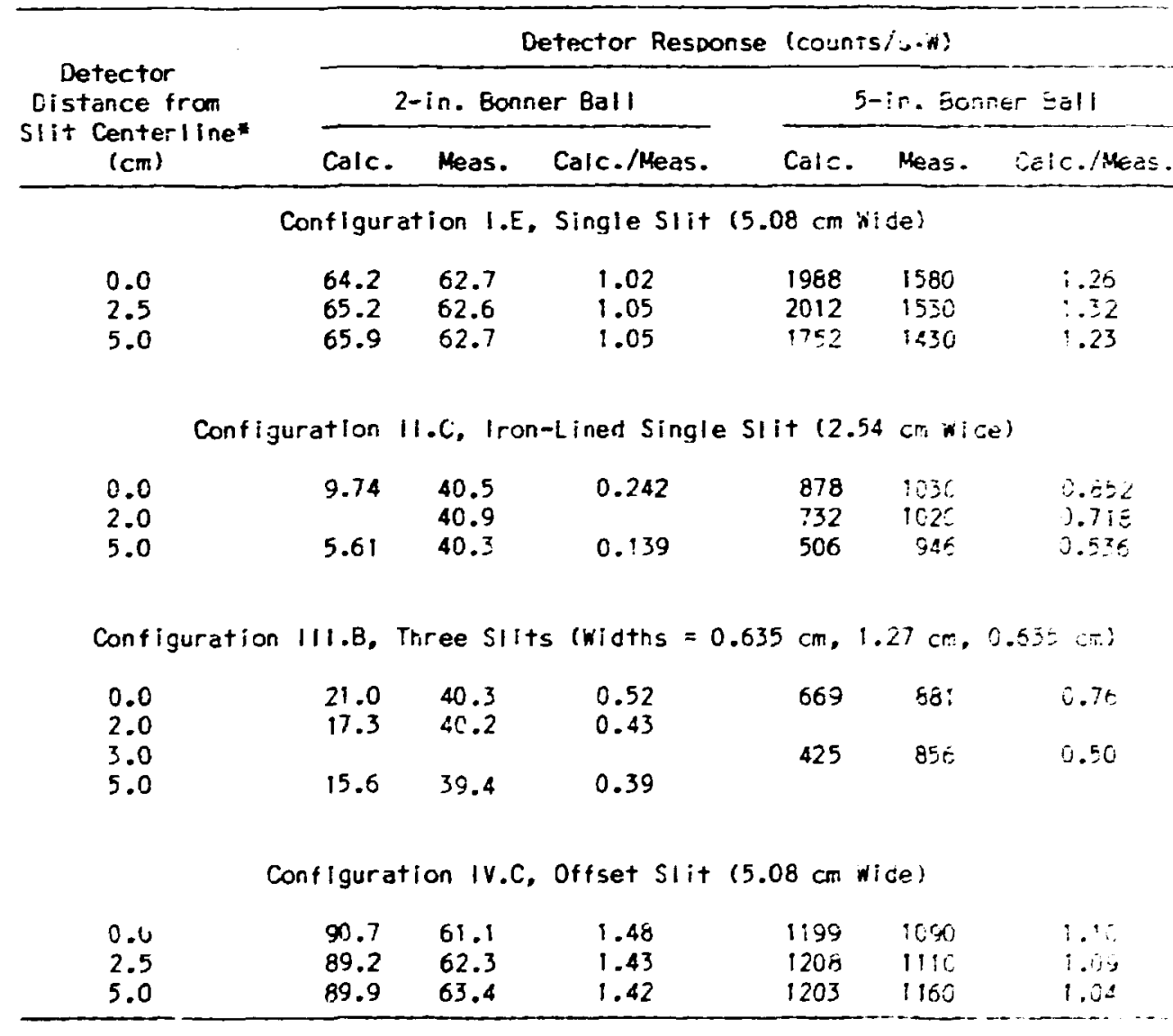

* For Conflguratlons I.E, II.C, and III.B, slit centerline Is in plane of : ea beam; for Configuration IV.C, the slit centerline is that of the exit slit. which is $30.5 \mathrm{~cm}$ from beam centerline. 
10. GCF? PLENLM SHIELD STUDIES: EXIT SHIELD EXFERIMENT

Experiment performed by:

F. J. Muckenthaler, J. L. Hul I, J. J. Manning

Analysis performed by:

D. T. Ingersoll, S. N. Cramer

10.1. Introduction

10.2. The Experiment

10.3. Analysis of the Experiment; Comparison of Calculated and Measured Results

10.3.1. Definition of Source

10.3.2. Transport Calculations for Fuel-Pin Configuration

10.3.3. Transport Calculatlons for Exit Shield

Configuration

10.3.4. Transport Calculations (or Measurements) for Exit Shield and Control Rod Conflgurations

10.4. Conclusions

10.5. Reterences 


\subsection{INTROOUCTION}

The sixth and final experiment performed at the TSF as part of the five-year Integral shield testing progran for the GCFR was for that portion of the plenur. shield identifled as the "exit shield." so called because it would provide an exit path for the hel lum coolant from the core into the plenum, while at the same time provlatig protection for the components within the plenum. By the time this experiant was performed, in 1980, the upflow GCFR design had been decided upon, and therefore the exit shleld was to be at the top of the core and the grid-plate shleld described in Chapter 7 was to ce at the bottom of the core. As a result, the components of concern were those in the upper plenum.

Like the grid-plate shield, the exit shield was designed as an integral part of the fuel element, the grid-plate shleld being incorporated Into one end of the element and the exit shleld beling incorporated into the opposlte end. Both shields consisted of $B_{4} C$, but whereas the grid-plate shleld was concentrated along the walls of the fuel element. leaving an axlal coolant path, the exit shield was concentrated on the fuel element axis, leaving a surrounding coolant path (see Fig. 2.3 in Chat ter 2).

The purpose of the TSF experiment was to determire the effectiveness of the exit shield in reducling the radiation damage to components in the upper plenum and, through analysis of the experiment, to provide a test of the calculational methods usec to develop the design. In additlon, the effect of a control rod penetration through the shield was studled. The experiment and analysls are summarized delow, both naving been presented In detall In refs. 1 and 2.

\section{:0.2. THE EXPERIMENT}

Up to a polnt, the experimental deslgin for the exlt shleld experiment was based on the design descrlbed in Chapter 7 for the grid-plate shleld experiment. As was the case In the grld-plate shleld experiment, It was important In the exit shleld experiment that the spectrum of neutrons Incldent on the shleld mockup represent the neutrons that would be emerging from the end of the GCFR core and axial blanket. Although the grid-plate shield and the exit shleld would be at opposite enis of the core, the spectra of neutrons incldent on the shields could be expected to be the same and therefore the mockup of the 
experimental source coula be the same In the two cases. Thus the first corfiguration tested in the exit shleld experiment (shown In FIg. 10.1) was basically the same as the fuei pin configurations used in the grid-plate shleld experiment; that is, it used the same fuel pin subassenhiles detaliud In FIgs. $7.2-7.5$ of Chapter 7. The major difference was that in the grid-plate shleld experlment both the nuber of pins and the spacing between iuel subassablles vere varled, while in the exit shield experiment only the 91-pln subassemcllies were used and the spacing between the subassemblles vas me'ntailued at $0.635 \mathrm{~cm}( \pm 58)$ throughout.

As shown in Table 10.1 he mockup with the fuel-pin subassemblles (Identified as Configuration (.A) was the first of 10 configurations Included in the exit shleld experiment. Since the fuel pin subassemblies had been thoroughly studied In the gridplate shield experiment, in this experiment the measurements beyond Configuration I.A were Iimited to those required to ensure that the magnitude and energy spectrum of the nelitron fliux were vell known.

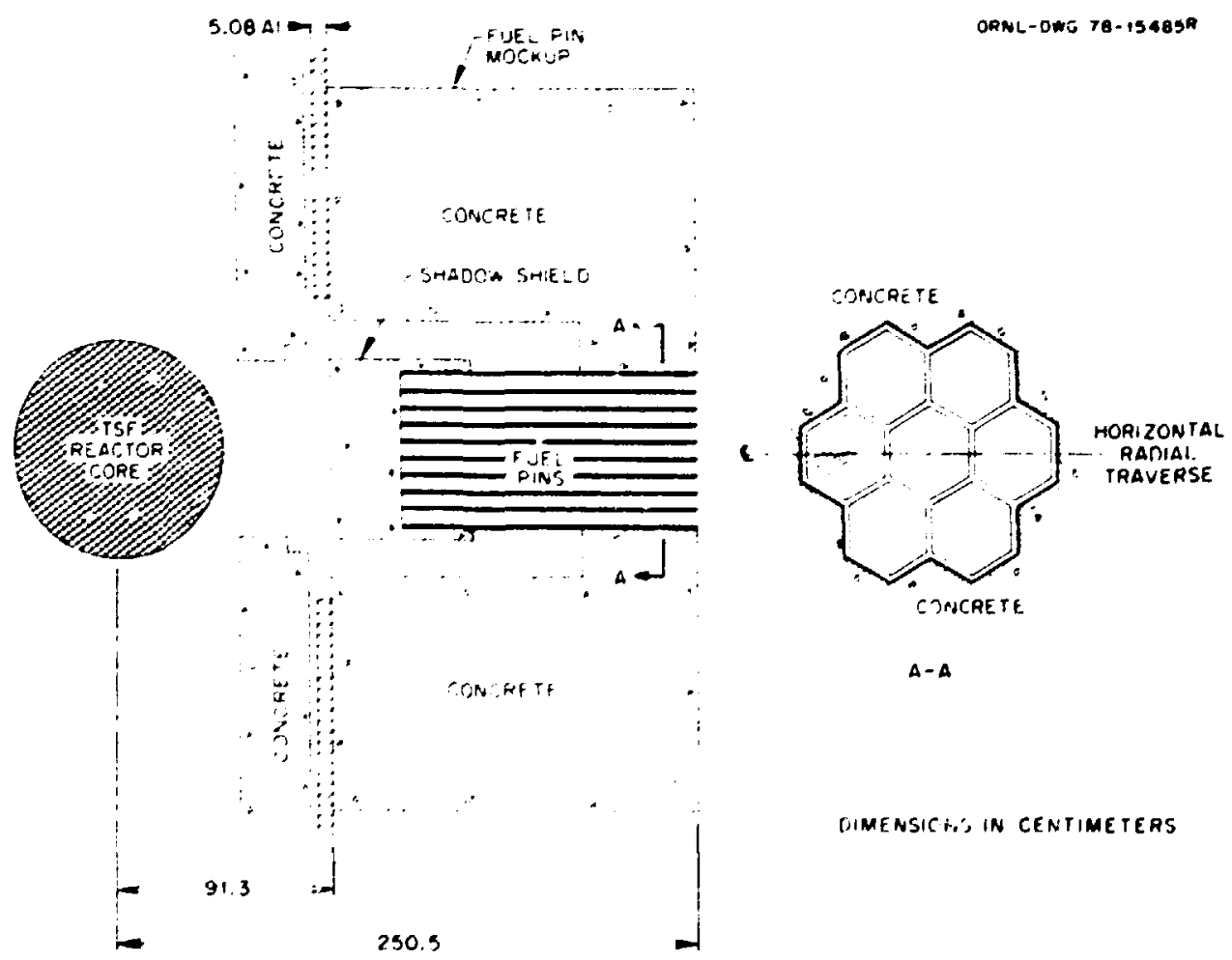

Fig. 10.1. Mockup of Shadow Shlold and Fuel PIn Suhassembiles for Exir Shield Experimont (Configuration $1 . A$ ). 
Table 13.1. Sumary of Configurations in GCFR Exit Shleld Exporiesnt

\begin{tabular}{|c|c|c|}
\hline Conf I gurat I on & Description & Measirements \\
\hline $1 . A^{b}$ & 7 Fuel pin subassemblles & $88,18,5$ \\
\hline $11 . A^{b}$ & $\begin{array}{l}7 \text { fuel pln subessemblies + seven exit } \\
\text { shleld subassembl les }\end{array}$ & $88,18, S$ \\
\hline$\| 11 . A$ & $\begin{array}{l}6 \text { Fuel pin subassemblles + } 6 \text { exit shleld } \\
\text { subas semblles + unshleidod control rod sub- } \\
\text { assembly (rithout control rcd ackup) }\end{array}$ & $68, H B$ \\
\hline III.B & Conf. $|l| . A+$ ful ly Inserted control rod mockup & B8, $\mathbf{H B}$ \\
\hline $111 . c^{b}$ & Conf. $111 . A+50$, Inserted control rod nockup & B8, $\mathrm{KB}$ \\
\hline III.0 & Conf. III.A + fully witharan control rod mockup & 88, 18 \\
\hline IV.A & $\begin{array}{l}6 \text { Fuel pin subassemblles }+6 \text { exit shield sub- } \\
\text { assembl les }+ \text { shlel ded control rod subasseably } \\
\text { (without control rod mockup) }\end{array}$ & $B B, H B$ \\
\hline IV.B & Conf. IY.A + fully inserted control rod mockup & B8, 18 \\
\hline IV.C & Cont. : v.A + 50 s Inserted control rod mockup & $\mathrm{BB}, \mathrm{HB}$ \\
\hline IV.0 & Conf. IV.A + 'ully wlthdram control rod mockup & B8, 18 \\
\hline
\end{tabular}

${ }^{\circ} B Q=$ Bonner balls; $H B=$ Horn; ak button; $s=$ spectrometers.

conflgurations for whlch analysls was pertormed.

For the serond conf Iguration (II.A) seven exit shir id subassemblles were added behind the fuel subassemblles. The design of the ex: t shleld subassemblles is shown $n$ Figs. 10.2 and 10.3. Centered on the axIs of exch subassembly were two $B_{4} C$ cones of unequal length that were jolned ot their large ends. The corces were surrounded by Inner cyllndrlcal IIners, wth the Iliner around the larger cone having a constant InsIde dlameter and the Ilner orourd the smaller cone having the same taper as the cone Itself. The outs Ide wall of eech subassemb,y was hexagonel in cross section with essentially the same dimenslons is the fuel pln subessemblles, and the spom between the IIner and the outslde wall was fllled with $B_{4} C$ thet varled in denslty from 1.34 to $1.37 \mathrm{~g} / \mathrm{cc}$. The denslty of the $B_{4} C$ In the larger cone varled fram 1.28 to $1.32 \mathrm{~g} / \mathrm{cc}$, and that In the smaller cone from 1.29 to $1.32 \mathrm{~g} / \mathrm{cc}$. (Note: So that the exit shleld subassemblles would metch the fuel pln subessemblles, they were scaled down to 775 of the vol ume of the shlelds designed for the GCFR, except for the Iron wal I thlcknesses, whlch were the seme os In the fuel pin subassemblies.) 


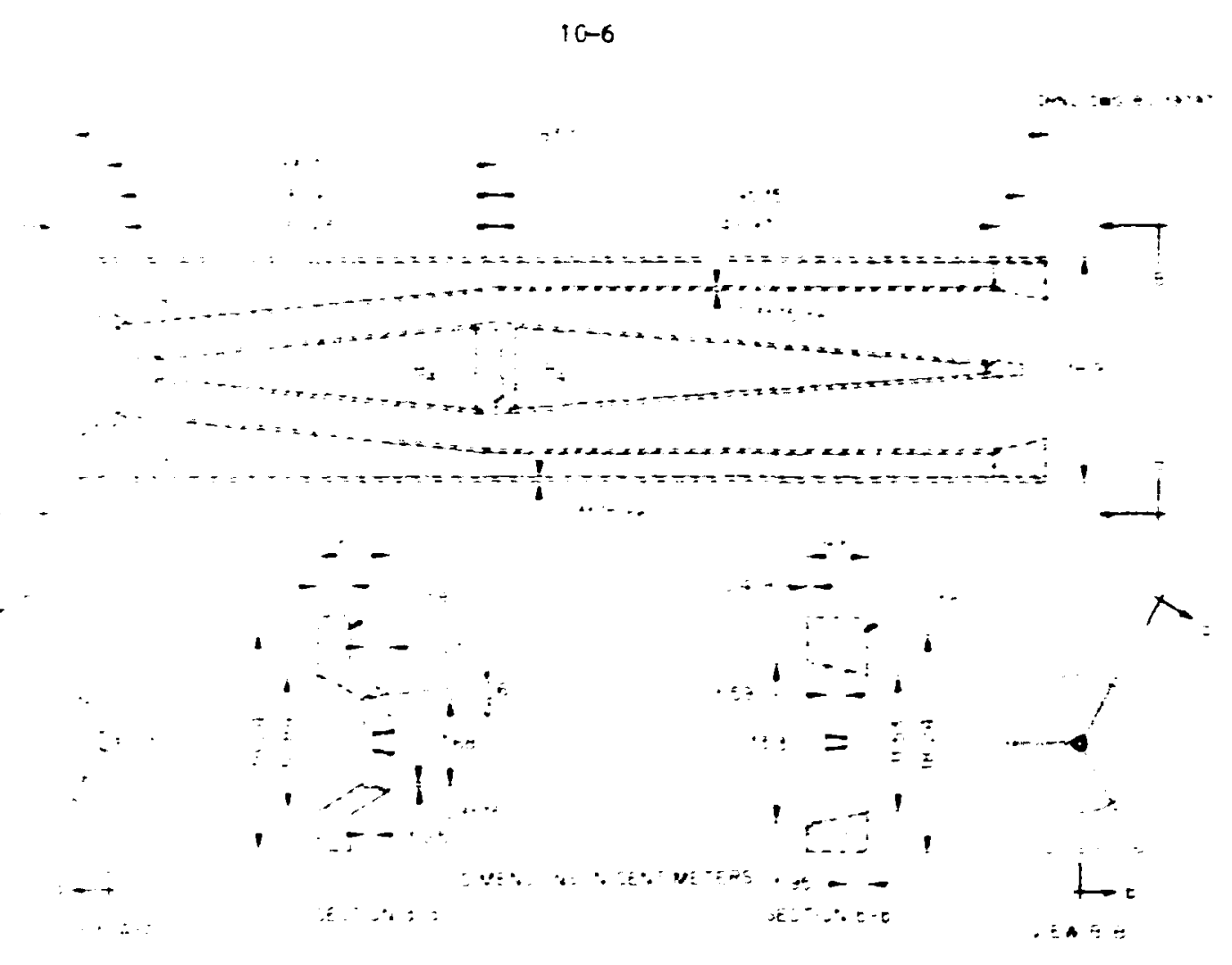

=ig. ic.2. Sctieretic of texit snielo Sucassembly.
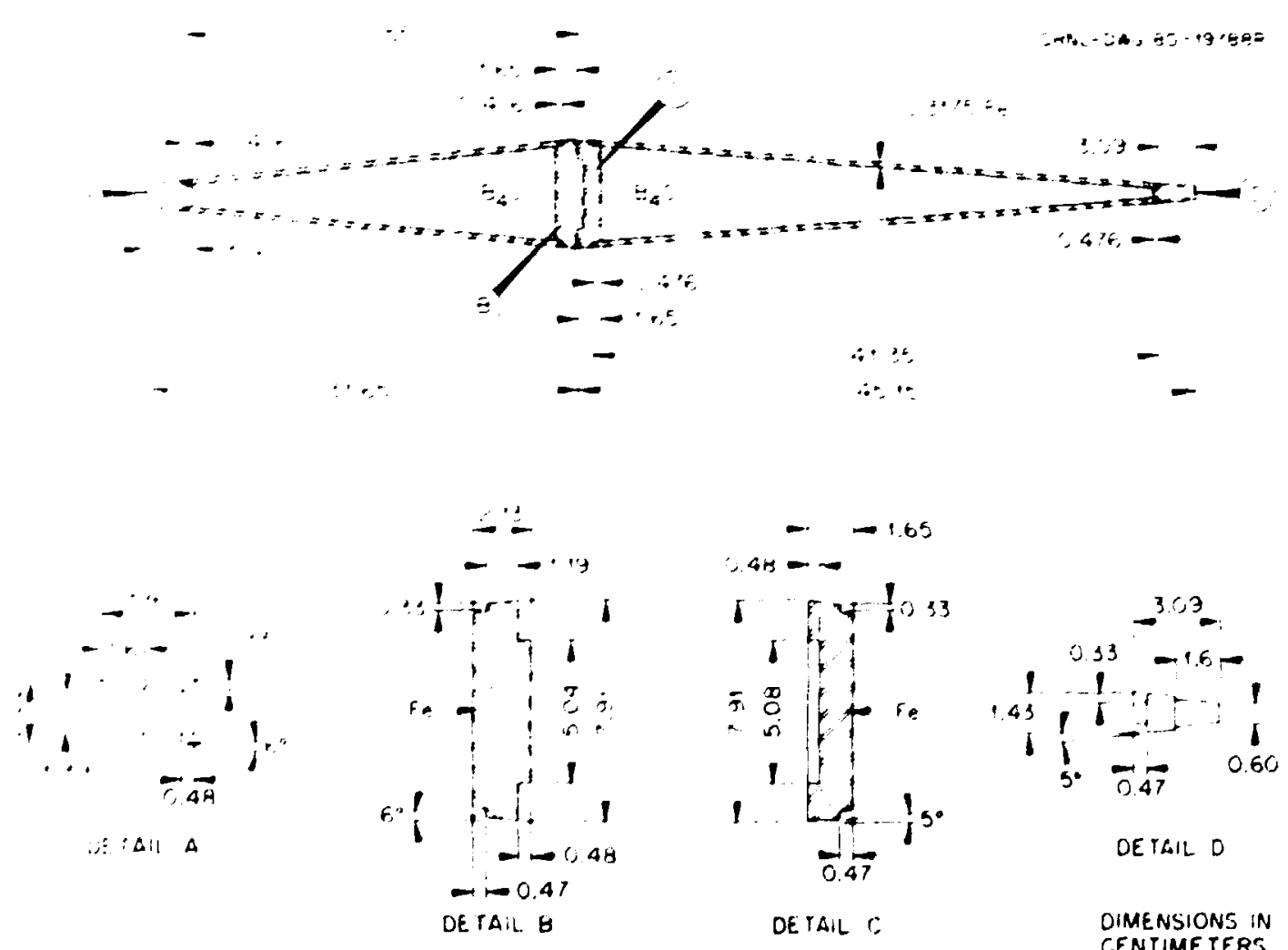

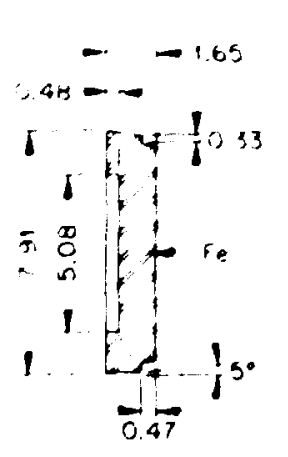

OE TAIL :

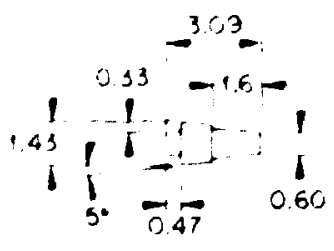

DE TAIL D

DIMENSIONS IN CENTIMETERS

Fig. 10.3. Schenatic of $B_{4} C$ cones In Exit St lgld Subassembly. 
when inserted into the experimental conflguration, the ends of tte exit shielc sutasseablies contairing the smaller cones were positloned agalnst the ends of the fuel subassenbiles. Ir: all cases the axes of the fuel subassemblies were ailgod with the axes of the shielc subassemblies so that the neutror streaning paths bet reen the subassemblies voult extend uninterrupted through the fuel and shlelc sec lons. A sketci of the resulting configuration (II.A), which is surrounded by concrete ined with 0.95 -cmtrick iron, is shown in Fig. 104.

For the remaining conflgurations in the experiment the central fuel and exit shield sutassemblies were replaced ith a control rod subassembly of the same outside dimensions. A sketch of the subassembly housing is siown in Fig. 10.5. As noted, the outer wail was hexagonal in cross section while the inner liner was cylindrical. The housing was iatricated in two sections, one $82 \mathrm{~cm}$ lon, and the other $128.5 \mathrm{~cm}$ long. In the shorter section the space between the outside wall and the IIner was always empty, while in the longer section the space was sometlmes fllied with $b_{4} \mathrm{C}$ at a density of $1.39 \mathrm{~g} / \mathrm{cc}$. (Actually, two long sectlons were fabricated, one with and one without the $B_{4} C$ fllling.)

-he first experlmantal conf Iguration containling the control rod subassembly houslng, out not the mockup of the contral rod Itself, was Identifled as Conflguration III.A. In this configuration the "unshlelded" housing was used; that Is, the long sectlon did not contain $B_{4} C$ between the outer wal: and the IIner. A sketch of the contiguration Is presented In Flg. iU.c and and vlews are shown In FIgs. 10.7 and 10.8. The alm was to malntaln a caistent spacing of $0.65 \mathrm{~cm}$ between subassemblles, but as noted In Flg. 10.7, this was not accomplishad. Also, because or the compact spacing of the subassemblles, a relatively large vold existed between the array and the iron IIner of the surrounding concrete.

Configurations III.B, III.C, and III.D consisted of Conf Iguration III.A with the control rod mockup positioned at varlous locations within the control rod subassembly. The mockup Itself conslsted of two sections, each $60 \mathrm{~cm}$ long and $15.9 \mathrm{~cm}$ In diameter and each fllled with $B_{4} C$ at a denslty of $1.32 \mathrm{~g} / \mathrm{cc}$ (see botton sketch In FIg. 10.9). To the control rod was attached a control-rod follower, also deplcted In FIg. 10.9 and also fabrlcoted in two sectlons and fllled with $B_{4} C$ cat densltles of 1.30 and $1.31 \mathrm{~g} / \mathrm{cc}$ in the smaller and larger section, respectlvely). With the control rod and control rod follower each divided Into sectlons, varlous comblndtions of the two coul. .e used without any portion extending out from the end of the contiguration. 


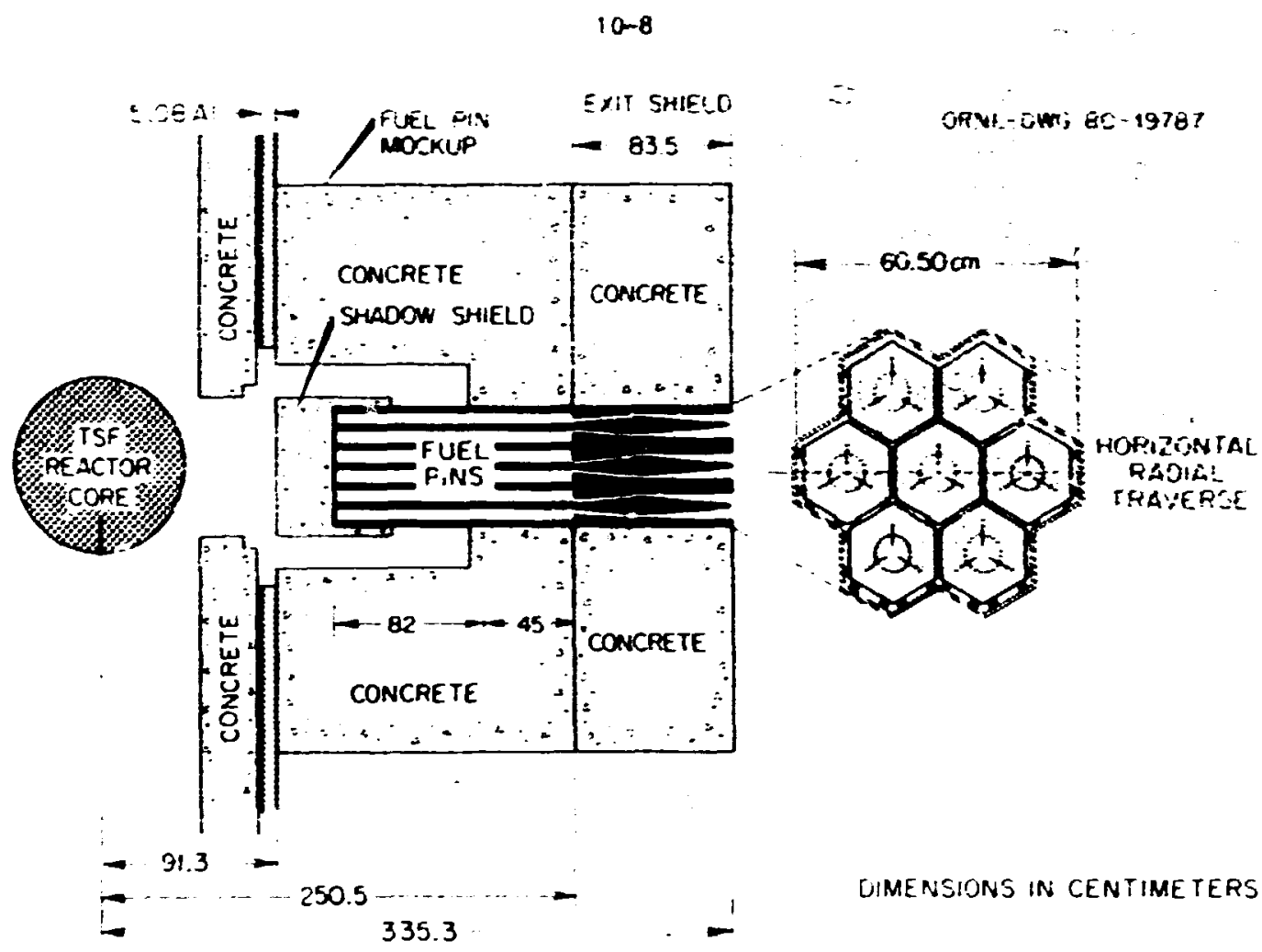

Fig. 10.4. Exprarlmental Contiguration Consisting of Seven Fuel Pin Subassemblies and Seven Exit Shield Sulassemblles (Configuration $11 . A$ ).

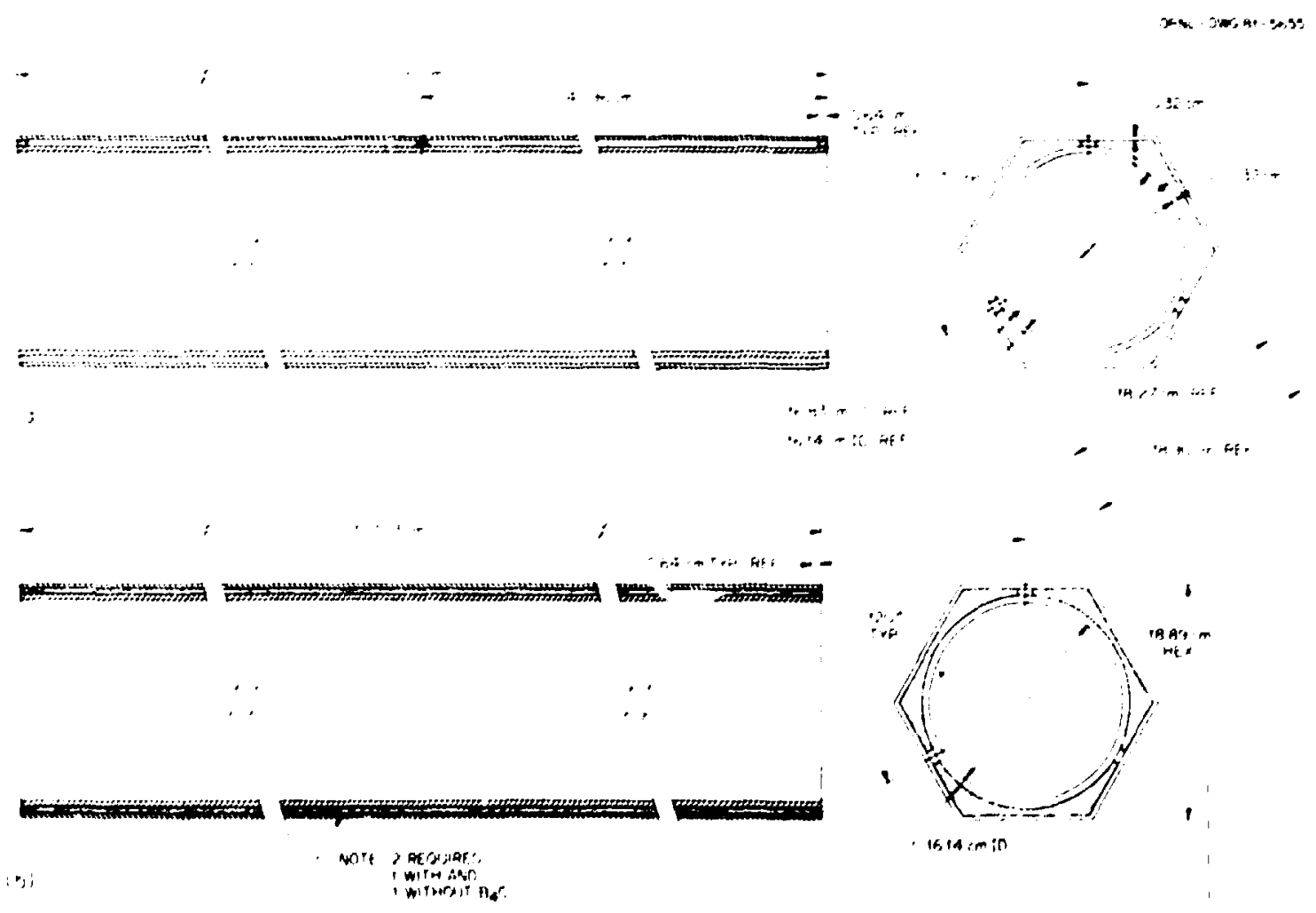

Fig. 10.5. Sketch of Control Rod Subassembly Heusing. 
$10-9$

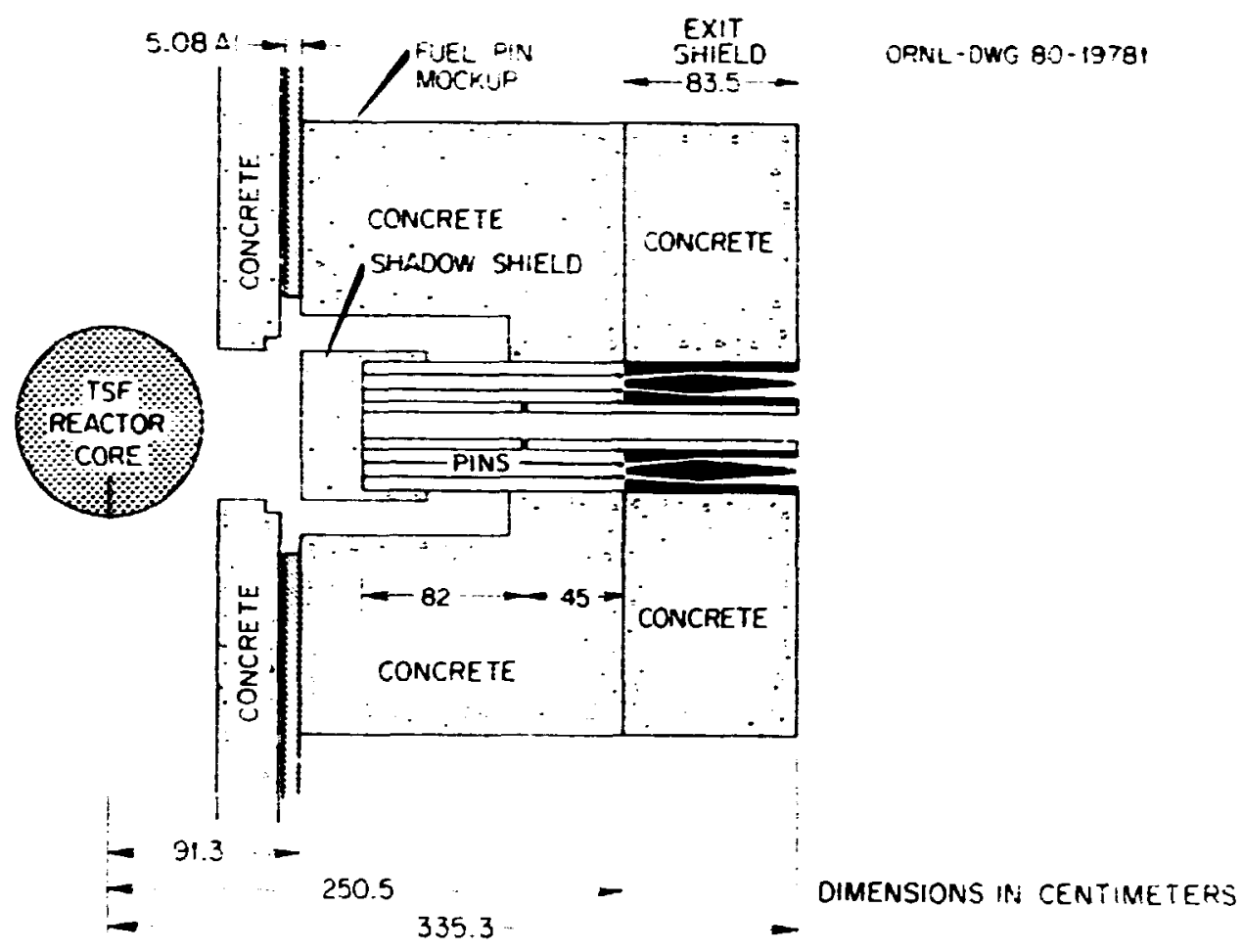

Fig. 10.6. Experimental Configuration Consisting of Six Fuel Pin Subassemblles and Six Exit Shleid Subassemblies with Unshlelded Central Control Rod Subassembly Housing.

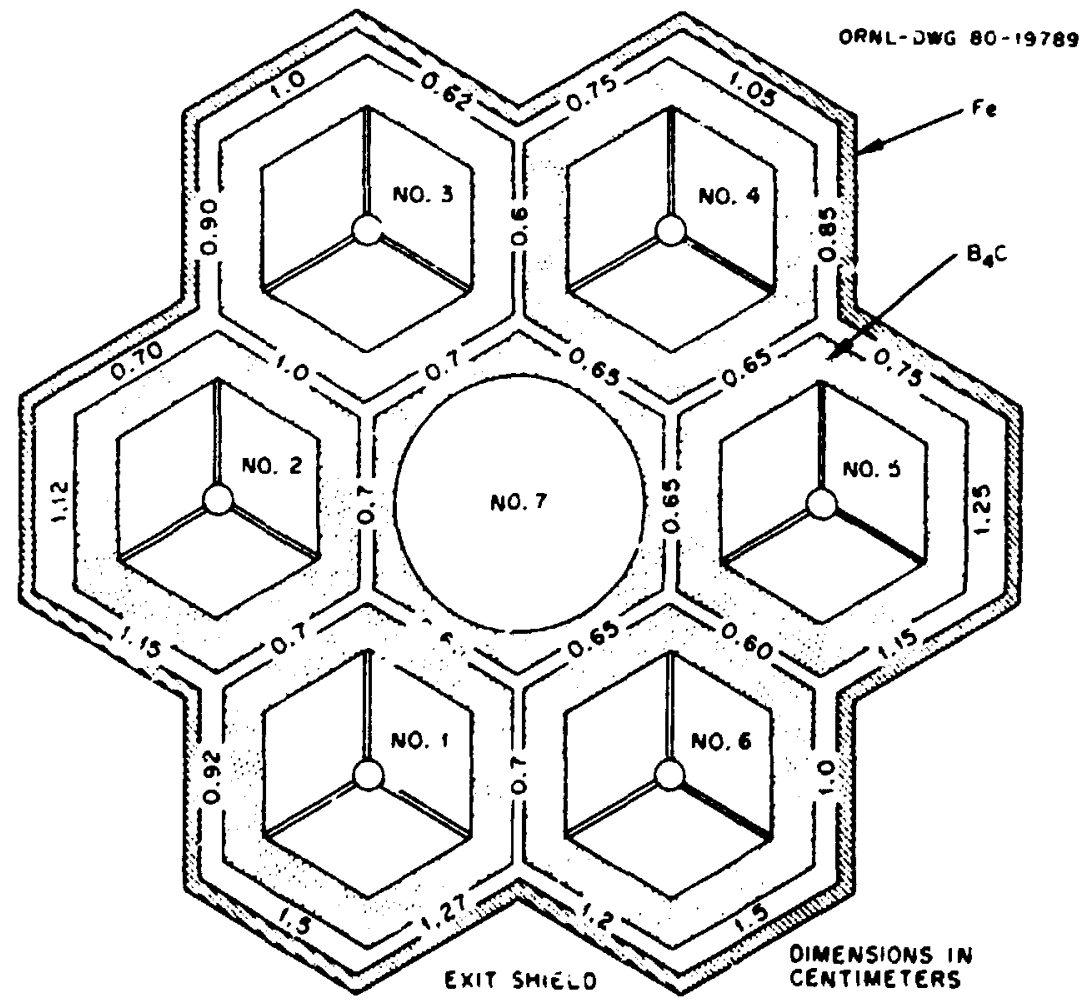

FIg. 10.7. Measured Void Spacings Between Six Exlt Shleld Subassemblles and Central Cont ol Rod Subassembly Housing. 


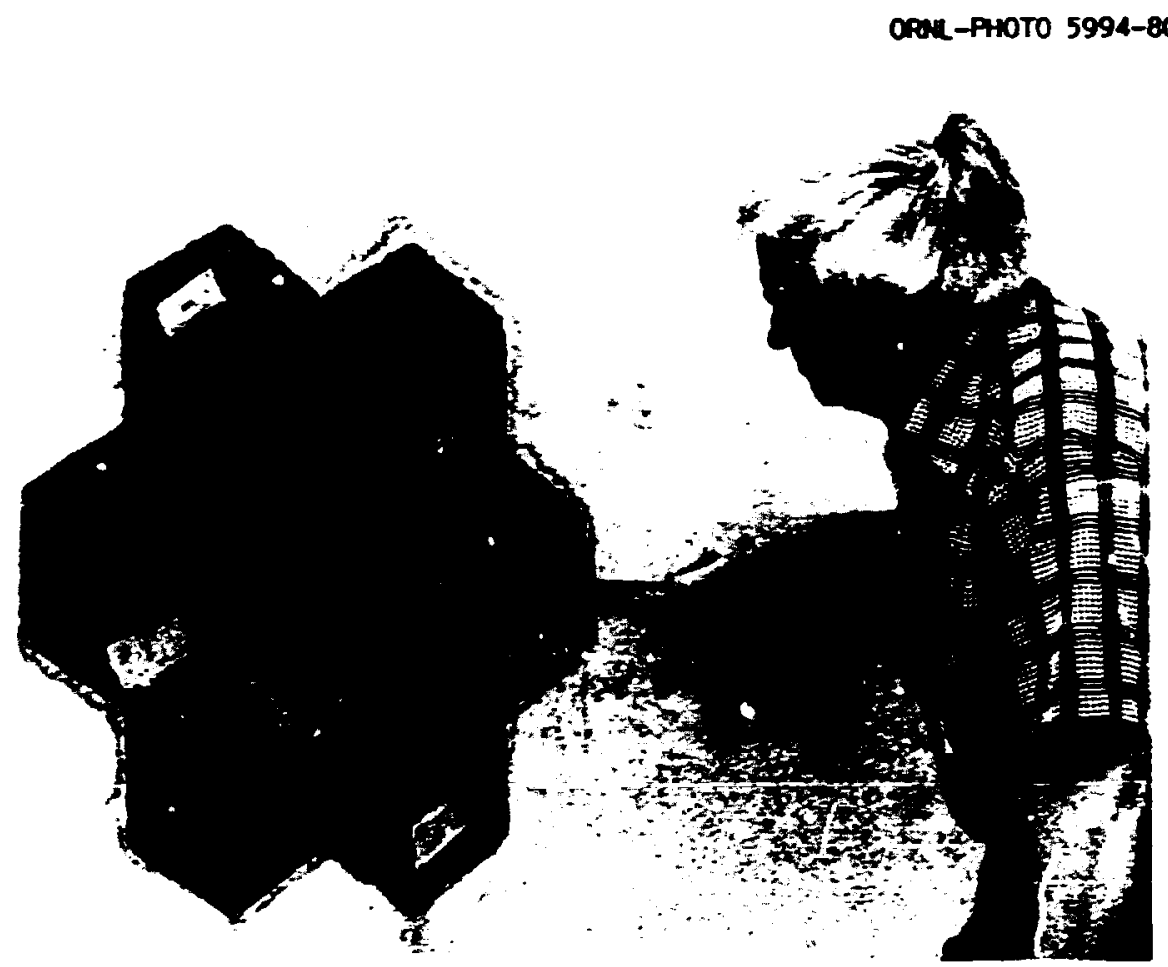

Fig. 10.8. Mockup of Exit Shield (SIx Subassemblles) with Central Control Rod Subassembly Housing.

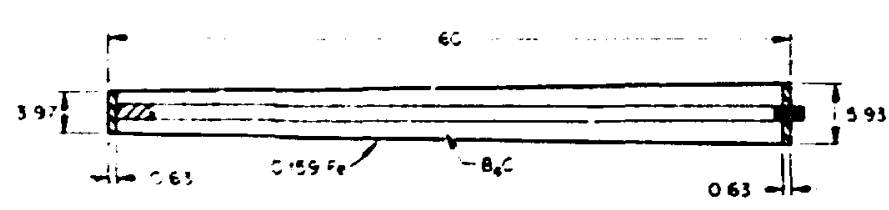

ande- Owe on-597060
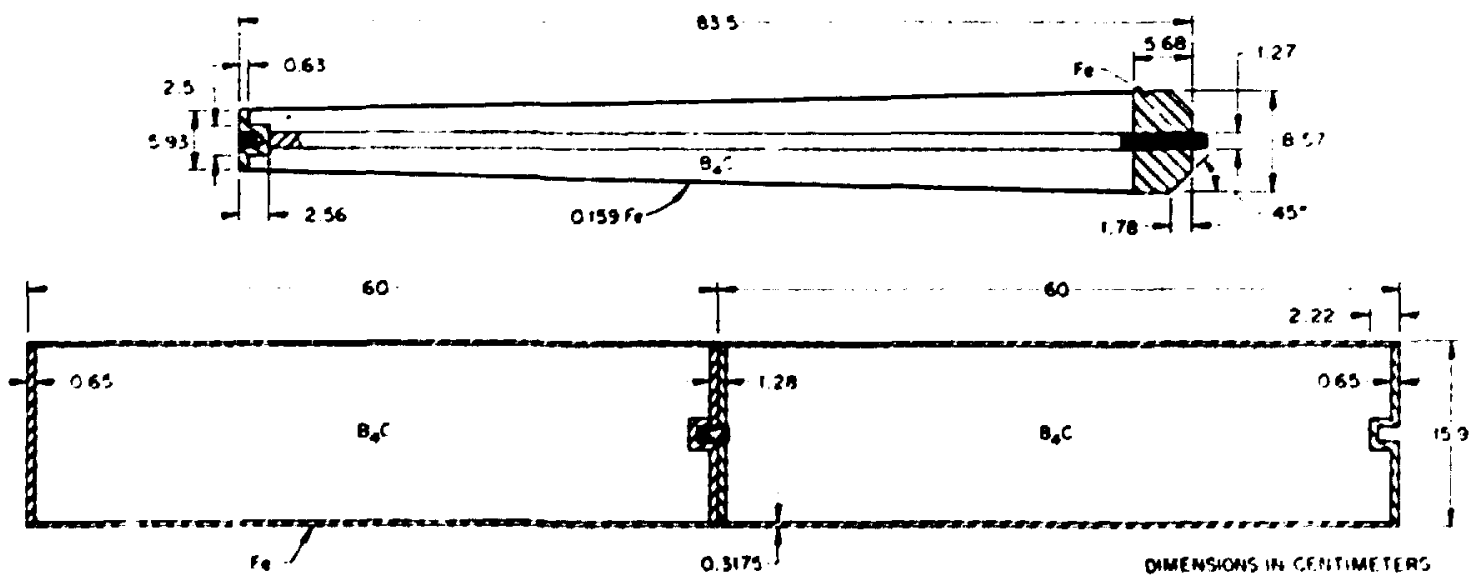

FIg. 10.9. Mo:kup of Control Rod (Bottan Sketch) and Control Rod Fnllower (Top SWatchgs). 
Conf igurations IY.A - IV.D vere Identical yith Configurations III.A - III.D except that the larger section of the control rod subassenbly housing was shielded; that is, the section containing $\mathrm{B}_{4} \mathrm{C}$ between the outer wall and the I iner was used.

During the experiment neutron flux measurements vere made beyond each configuration with Bonner balls and the Hornyak button. For Configurations $I I 1 . A$ and IV.A, Bonner ball and Hornyak button measurements were also made along the axis of the control rod subassenbly (control rod mockup absent) tran immediately behind the concrete shadow shield to beyond the configuration. In addition, neutron spectral measurements were made beyond Configurations $I . A$ and $I I . A$ with the NE-213 spectrometer and the hydrogen counters.

\subsection{ANALYSIS OF THE EXPERIMENT; COMPAPISON OF CALCULATED AND MERSURED RESULTS}

Because the U.S. GCFR r. ogran was suspended during the course of this experiment and cioseout of the program was to be expedited, the analysis of the experiment was IImited to three of the measured configurations: I.A, which was the fuei pin array; II.A, which contained the full exit shleld of seven subassmblles; and III.C, In whIch the control rod mockup was partlally inserted in the subassembly housing containing no $B_{4} C$. In vlew of this I imitation, interpretation of the experimentel data for the other configurations Is largeiy based on comparisons with the data for the analyzed conf Igurations.

\subsubsection{Definition oí Source}

1.: was the case for the grid-plate shield experiment, the radiation source for the exit shleld conflgurations consisted almost entirely of neutrons born from fissions in the fuel pins simulating the GCFR core and blanket, the fisslons being induced by TSR-II neutrons that scattered around the shadow shield shown In Fig. 10.1. Since the technlque for defining the source in the analysis was the same as that descr lbed in Section 7.4.1 of Chapter 7, It will not be discussed here. Suffice it to say that the final step of the technlque was a DOT calculation trom which an internal boundary source was output in the plane including the Inner surface (reactor side) of the shadow shield, and this source was then used as the external input source for the analysis. As the calculation 
progressed threugh the configuration, other internal boundary sources were output and simillarly used as input sources for succeeding steps.

The Initial source calculation used the 51-group GCFR cross sections with $P_{3}$ expansion and the 150-angle quadrature set.

\subsubsection{Transport Calculations for Fuel-PIn Configuration}

In the experiment 2- and 5-In. Bonner ball measurements and Hornyak button measurements were made 39.5 an beyond the fuel-pin configuration (1.A) and within its horizontal midplane. At $155.4 \mathrm{~cm}$ beyond the conflguration, on-axis measurements were made with the 2-,5-, and 10-in. Bonner balls and with the NE-213 spectrometer and hydrogen counters.

The first calculations for Configuration I.A were DOT calculations using the cylindrica! annular-ring model shown In FIy. 10.10, the standard GCFR 51-group $P_{3}$ cross secrions, and a 96-angle (symmetric $S_{12}$ ) quadrature which it was thought would be a good compromise between the 70-angle and 150-angle quadratures used in the grid-plate shleld analysis (see Chapts: 7). Following the calculation for the model in Fig. 1J.10, the boundary flux $\geqslant$, the end of the configuration was extracted from the output flux tape (via a speclal computer program) for use as a boundary source in a followup DOT calculation for a single vold zone that encompassed the detector locatlons close to the configuration (with in $40 \mathrm{~cm}$ ). For larger distances, the FALSTF code was used to transport the flux to the detector locations.

The material compositions assumed for the calculation are given in Table 10.2. In the Initial calculations, Concrete MIx 11 was used for the concrete regions shown In the model. This $m i x$ is a long-standing ansiy_;s of concrete blocks routinely used in TSF experiments and represents the composition assumed for the analysis of the grld-plate shleld experlment. Horever, when the resulting DOT neutron fluxes $30.5 \mathrm{~cm}$ beyond the configurstion were folded with the response functions for the 2- and 5-In. Bonner balls, the calculated responses were signlficantly higher than the measured responses, 


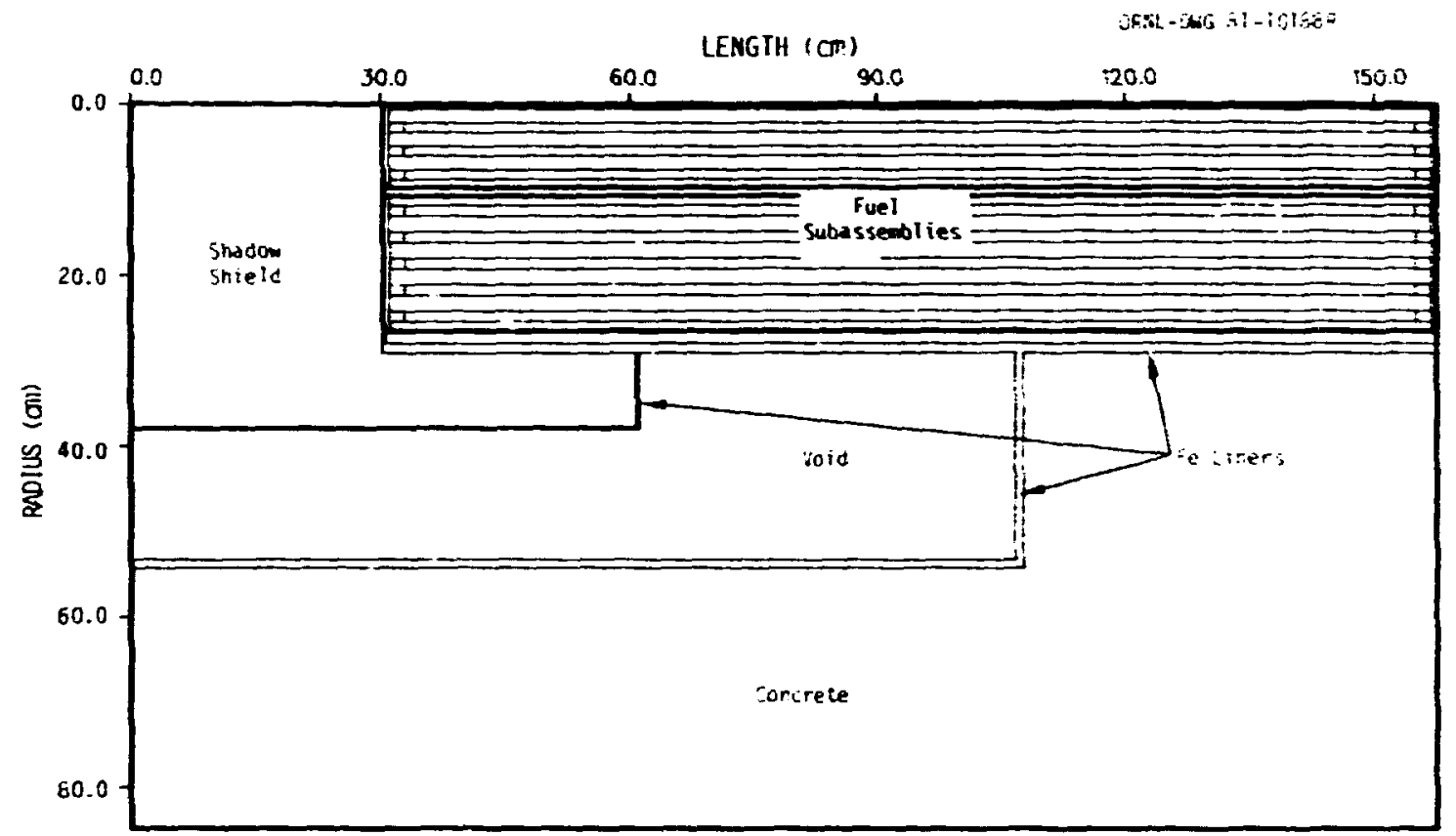

Fig. 10.10. Tro-dimenslonal Cylindrical Model Used for DOT Caiculations of Configuration 1.A. Model had 61 axlal Intervals and 60 radial Intervals.

Table 10.2. Material Atom Denslties Used in Analysls of Exit Shield Experiment

\begin{tabular}{|c|c|c|c|c|c|c|c|}
\hline & \multicolumn{7}{|c|}{ Materlal Composition [atoms/(barn $\left.\left.\cdot \mathrm{cm}^{2}\right)\right]$} \\
\hline & $\begin{array}{c}\text { Carbon } \\
\text { Steel }\end{array}$ & $\mathrm{B}_{4} \mathrm{C}^{\mathrm{a}}$ & Fuel PIns & End Plug & $\begin{array}{l}\text { Spacer } \\
\text { Plates }\end{array}$ & $\begin{array}{c}\text { Concrete }^{c} \\
M I \times \quad 1\end{array}$ & $\begin{array}{c}\text { Concrete } \\
\text { Mix } 12 \\
\end{array}$ \\
\hline$H$ & $-\infty$ & - & - & - & -- & $8.88(-3)$ & $1.067(-2)$ \\
\hline $8-10$ & - & $1.095(-2)$ & - & $\ldots$ & $-\infty$ & - & $\ldots$ \\
\hline$B-11$ & -- & $4.437(-2)$ & - & -- & -- & -- & $-\infty$ \\
\hline c & $9.18(-4)^{d}$ & $1.496(-2)$ & - & - & $5.53(-4)$ & $7.97(-3)$ & $1.093(-2)$ \\
\hline 0 & -- & $-\infty$ & $3.394(-2)$ & - & $-\infty$ & $4.202(-2)$ & $4.654(-2)$ \\
\hline $\mathrm{Na}$ & - & -- & - & - & $\infty$ & $2.73(-5)$ & $4.618(-6)$ \\
\hline $\mathrm{Mg}$ & - & -- & - & - & - & $1.44(-3)$ & $4.823(-3)$ \\
\hline$A \hat{I}$ & - & - & $1.447(-2)$ & $6.025(-2)$ & $2.40(-2)$ & $4.14(-4)$ & $3.658(-4)$ \\
\hline SI & -- & - & $-\infty$ & $\cdots$ & --- & $3.83(-3)$ & $2.682(-3)$ \\
\hline $\mathbf{s}$ & -- & - & - & - & - & $1.015(-4)$ & $3.376(-5)$ \\
\hline$k$ & $-\infty$ & $\cdots$ & $\infty$ & $-\infty$ & -- & $2.34(-3)$ & $1.504(-4)$ \\
\hline Co & - & - & - & - & - & $1.0(-2)$ & $8.498(-3)$ \\
\hline $\mathrm{Fe}_{\mathbf{e}}$ & $8.372(-2)$ & $-\infty$ & $\infty$ & - & $5.04(-2)$ & $2.64(-4)$ & $1.684(-4)$ \\
\hline NI & -- & - & - & - & - & - & - \\
\hline $1-235$ & -- & $-\infty$ & $3.42(-4)$ & $-\infty$ & ... & - & -- \\
\hline $1-238$ & - & 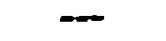 & $1.663(-2)$ & - & $\cdots-$ & -- & -- \\
\hline
\end{tabular}

Materlal denslty of $1.3 \mathrm{~g} / \mathrm{cc}$.

bor 91 plns or assembly.

CAnalysis of standard TSF concrete; assumed for grld-plate shleld experiment colculatlons.

Analysis of concrete used in the experimental configuration. 
especialiy for detector locations opposite the concrete (see Fig. 10.11). Since a study performed during the analysls of the grid-plate experiment had indicated the importance of using the correct composition of concrete In the calculations, the calculations were repeated with Concrete Mix 12, which is a composition based on a chemical analysis of the concrete actuilly used in the experiment. The second mix yielded results for the 2-in. Bonner bali that were in excellent agreement with the measurements for locations opposite the concrete but were somewhat lower than the measurements for locations opposite the fuel plins. The resu:ts for the 5-in. Bonner ball also were slightly better with the second $m i x$; therefore for al I subsequent calculatiors Concrete Mix 12 was assumed.

While it is not obvious from Fig. 10.11, subsequent calculations for the exit shield configuration (see Section 10.3.3) showed that the 96-angle quadrature vas inadequate; therefore all the foregolng calculations were repeated with the 150-angle quadrature. The results, presented in Fig. 10.12, show closer agreement of the measured and calculated 2-in. Bonner bali responses for locatlons opposite the fuel pins, the maximum discrepancy of 8.48 belng the same order of magnitude as the combined experlmental and analytical uncertaintles. In the case of the 5-in. Bonner ball, the calculated responses continue to overpredict the measured responses, as much as 15 to $18 \%$ oppojite the fuel pins. However, this overprediction may be due to an Inadequacy of the blased quadrature in the single-vold zone, since a FALSTF calculation of the on-axis flux $30.5 \mathrm{~cm}$ beyond the configuration resulted In a 58 underprediction of the Bonner ball response. (Note: The perlodic fluctuations in the calculations shown in Fig. 10.12 result from the annular-ring model used to represent the pin array.)

A comparison of the calculated and measured Hornyak button responses $30.5 \mathrm{~cm}$ beyond Configuration I.A is shown in FIg. 10.13. Here the calculated responses are normalized to the measured responses on the centerline. As was repeatedly recognlzed dur ing the grid-plate shleld experiment, an unresolved and unexplained normalization problem exlsts with the Hornyak button response used In the analysis and the magnitude of the calculated responze is obvlously Incorrect. Flgure 10.13 indicates, however, that the relative spatial distribution of the response is correctiy predicted.

The neutron spectrum calculated for an on-axis location $155.4 \mathrm{~cm}$ beyond the contiguration is compared with the measured spectrum in Fig. 10.14. Unfortunately, within the time limits of the analysis it was not posslble to investlgate the reasons for the calculation underpredicting the spectrum. 

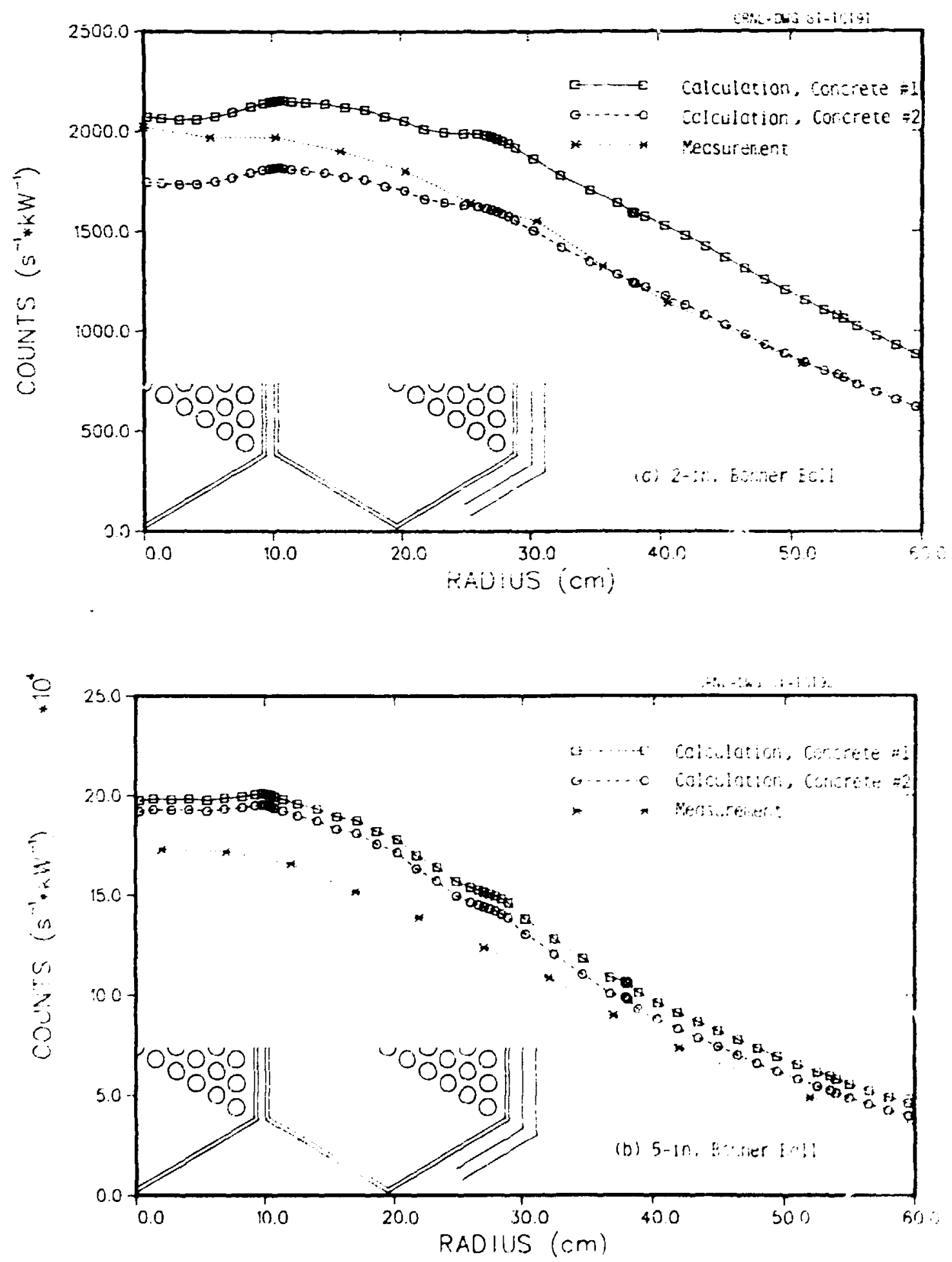

Fig. 10.11. Comparison of Mossured and Colculated Bonner Boll Responzes $30.5 \mathrm{~cm}$ Beyand Fuel-Pin Conflguration 1.A (96-Angle Quadrature Used in Analysis). 

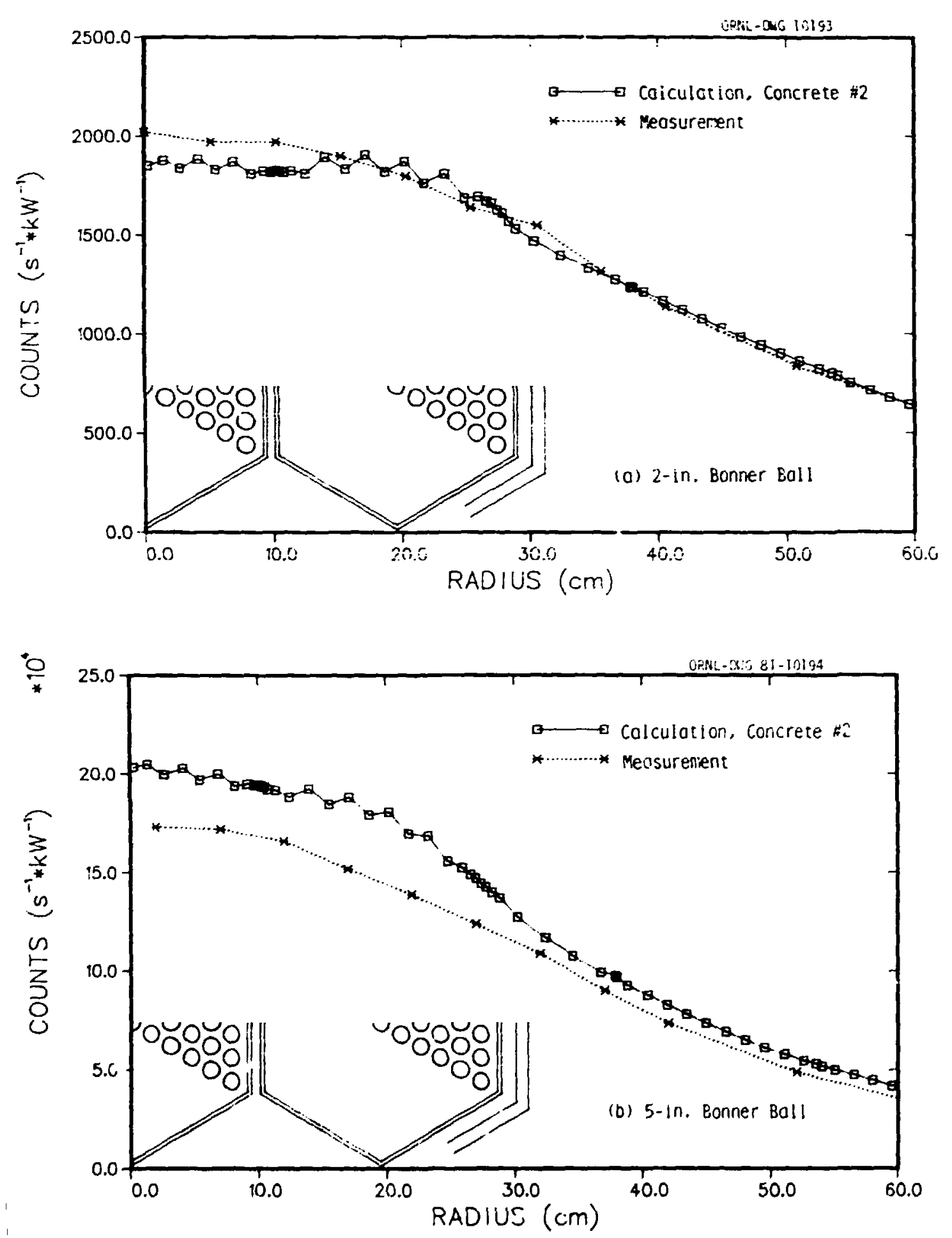

FIg. 10.12. Comporison of Measured and Colculated Bonner Ball Responses $30.5 \mathrm{~cm}$ Bayond Fuel-PIn Conflguration I.A (150-Angle Quadrature Used In Analysis). 
10-17

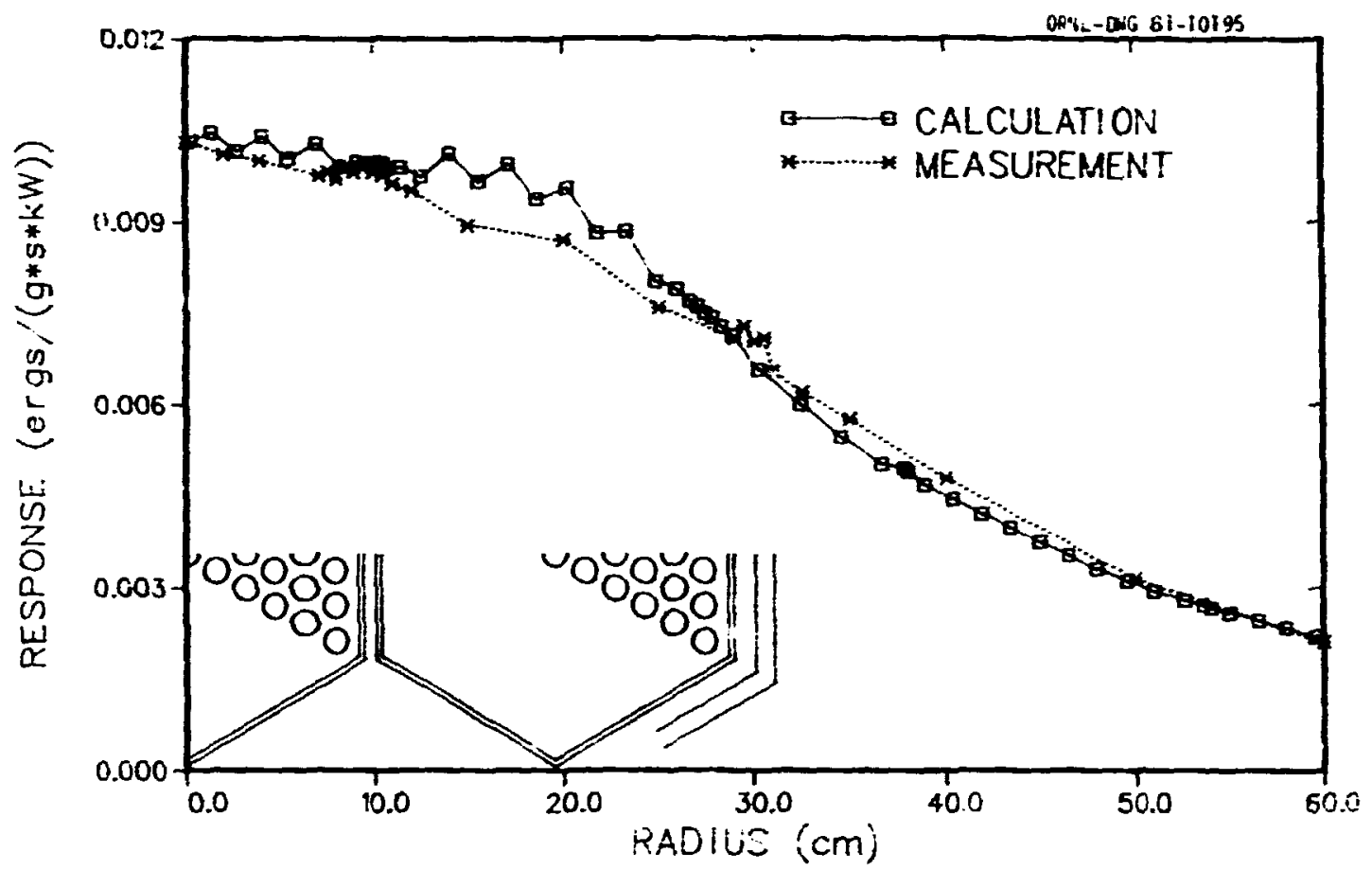

Fig. 10.13. Comparison of Measured and Calculated Hornyak Button Responses $30.5 \mathrm{~cm}$ Beyond Fuel Pin Conflguration I.A. Calculation normal Ized to measurement on axls (see text).

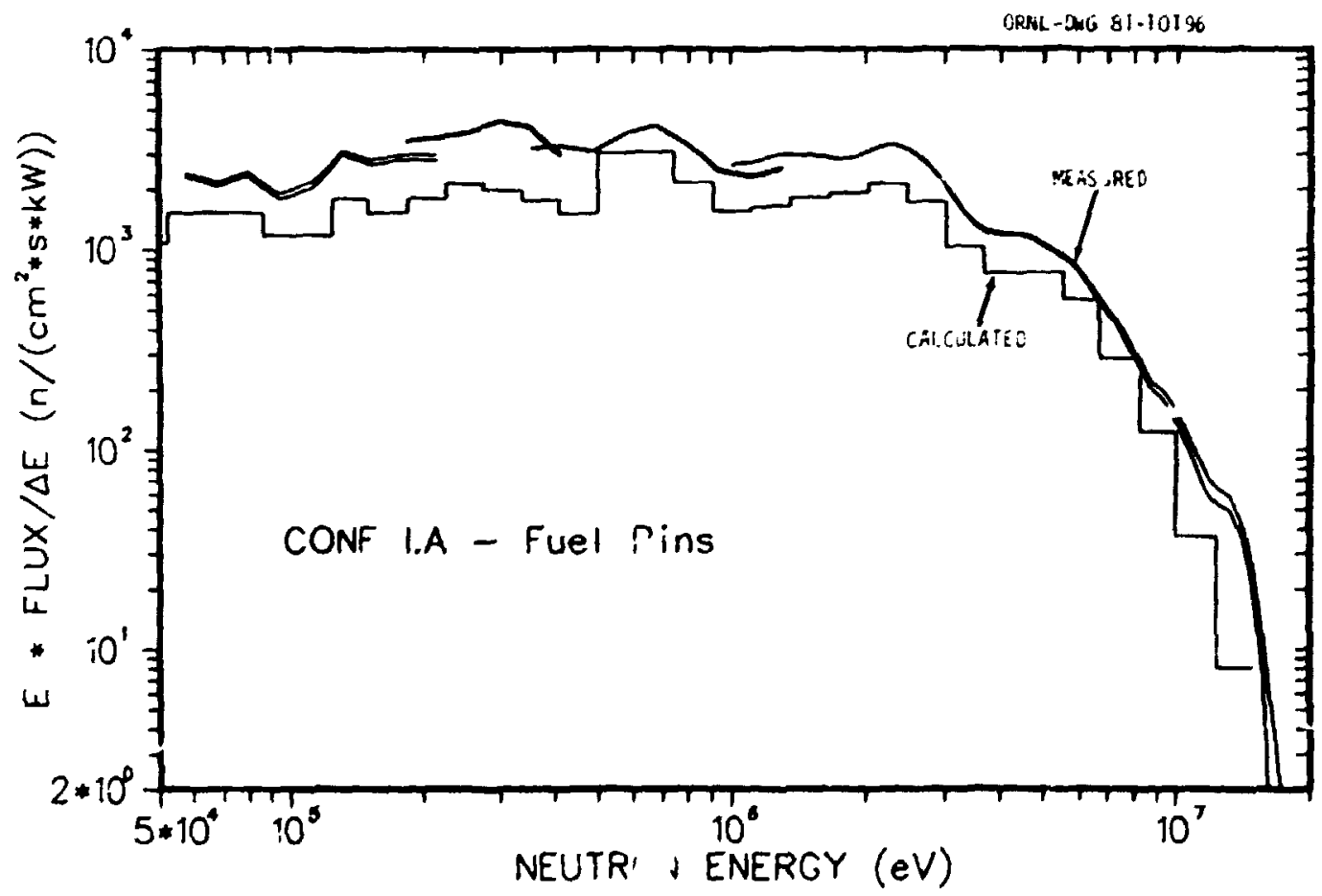

Fig. 10.14. Comparison of Moasured and Calculated Neutron Enargy Spectra $155.4 \mathrm{~cm}$ Beyond Fuel-PIn Contiguration I.A. 
Finally, the Bonner ball mesurements made at the 155.4-ca locatlon are gIven In Table 10.3. These responses were not calculated in the analysis.

Table 10.3. Masured Bonner Ball Responses on Axls $155.4 \mathrm{~cm}$ Beyond Fuel PIn Configuration I.A.

\begin{tabular}{cc}
\hline Bonner Ball & Rosponse (Counts/s.w) \\
\hline $2-i n$. & $2.84 \times 10^{-i}$ \\
$5-$ in. & $2.14 \times 10^{1}$ \\
$10-i n$. & $1.19 \times 10^{1}$ \\
\hline
\end{tabular}

10.3.3. Transport Calculations for Exit Shleld Conf Iguration

As described in Section 10.2 and shown in FIgs, 10.2 - 10.4, the es it shield conflguration (IdentIfled as Configuration II.A) consisted uf seven hexagonal Iy shaped subassemblles, each containing two $B_{4} C$-filled cones Interfaced at their bases and surrounded by hellum coolant passageways. The subassambl les were positioned in the experimental assembiy behind the fuel subassemblles and aligned with then.

In the experiment, radisl troverse neasureants were made with 2- and 5-In. Bonner balls at a distance of $39.8 \mathrm{~cm}$ beyond the conflguration and within its horlzontal midplane. In addition, centerline measurements were made with the Hornyak button, the 10-in. Bonner ball, the NE-213 spectrometer, and the hydrogen counters at a distance of $39.8 \mathrm{~cm}$ beyond the configuration. FInally, radial traverse mesurements were wade with the Hornyak button close behind the configuration (at $1.9 \mathrm{~cm}$ ).

Because of the importance $u^{\prime}$, r.is conflguration, the analysis used both the discrete ordinates code DOT and the Monte Carlo code MORSE. The cylindrical R-Z model for the DOT calculations is shown In FIg. 10.15. As noted, the Interfecad cone-sheped shields in the cuntral subassembly were modeled as stepped cylinders, while tl.a shlelds in the six outer sutessemblies were modeled as cylindrical ennull with smal for dimensions. These calculations continued to use the GCFR 51 -oroup $P_{3}$ cross sections, and, following on 


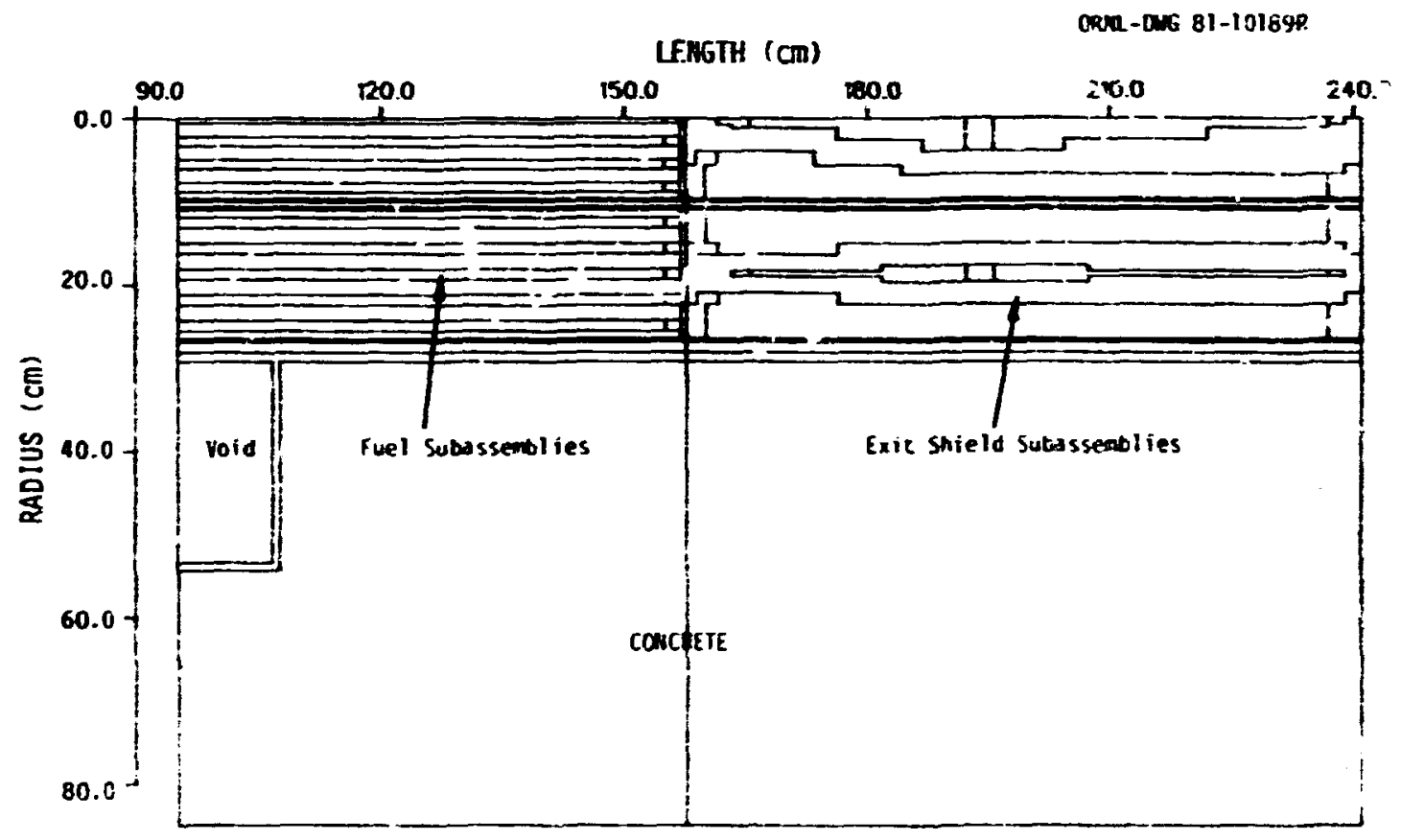

Fig. 10.15. Two-Dimensional Cylindrical Modal Used for DOT Calculations of Cor flguration II.A. Wodel had 60 axial intervals, 60 radial intervals in fuel region, and 62 redial Intervals in shield reglon.

unsuccessful attempt to use o symetric $S_{12}$ (96-angle) angular quidrature, they also continued to use the blased 150-angle quadrature that had been applled in the inalyses of the earl ler experiments.

Tra external boundary source for the Conflguration II.A calculation mas an Intermal boundery source that had bean teken from the prevlous Conflguration I.A calculation at a distance of $90 \mathrm{~cm}$ into the 'ruel region. As was the case for Configuration I.A, the fluses emerging fram the and of the conflguration were transported to the detector locetions by perforing a fol lowup DOT calculation for a single vold, with an output flux tape fran the preceding DOT run used us a boundery source.

Comparlsons of calculeried and wesured detector responses ere shoun In Fig. 10.16 for the Bonner ball redial treverese of $39.8 \mathrm{~cm}$ and In FIg. 10.17 for the Hormyck button redial troverse of $1.9=0$. It is cluer frem these comperisons that the strening cherecteristics of the exit shield ere more proporly calculated with the iso-engle quas sture set then with the gr-single set. Though sl ightiy alspleced anirg to wodel ing 

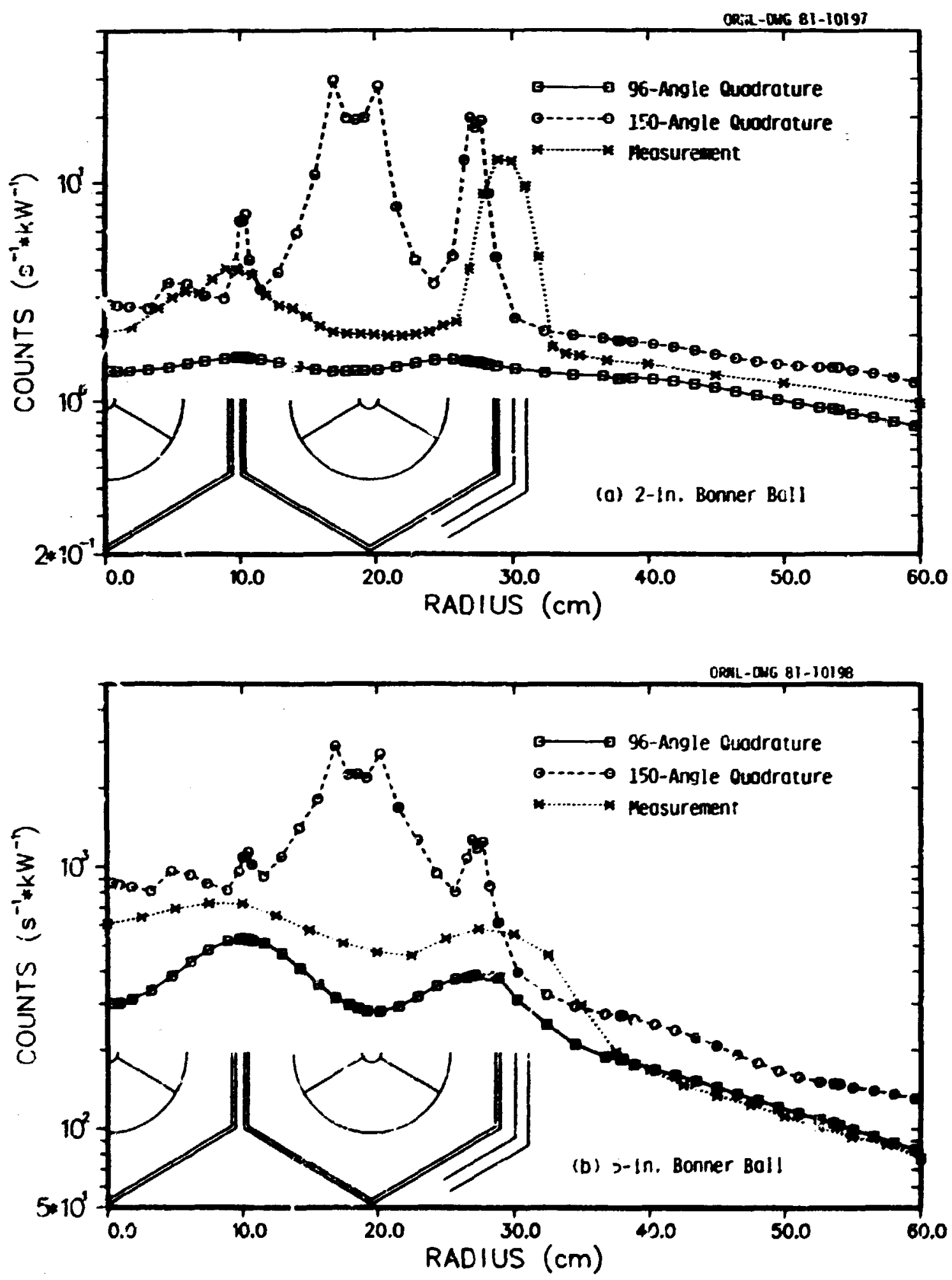

rig. 10.16. Somporison ef Measured and DOT-Col culates Bonmer Ball Rasponsas $39.8 \mathrm{~cm}$ Baryond Exlt Shield Cont lguretion II.A. 


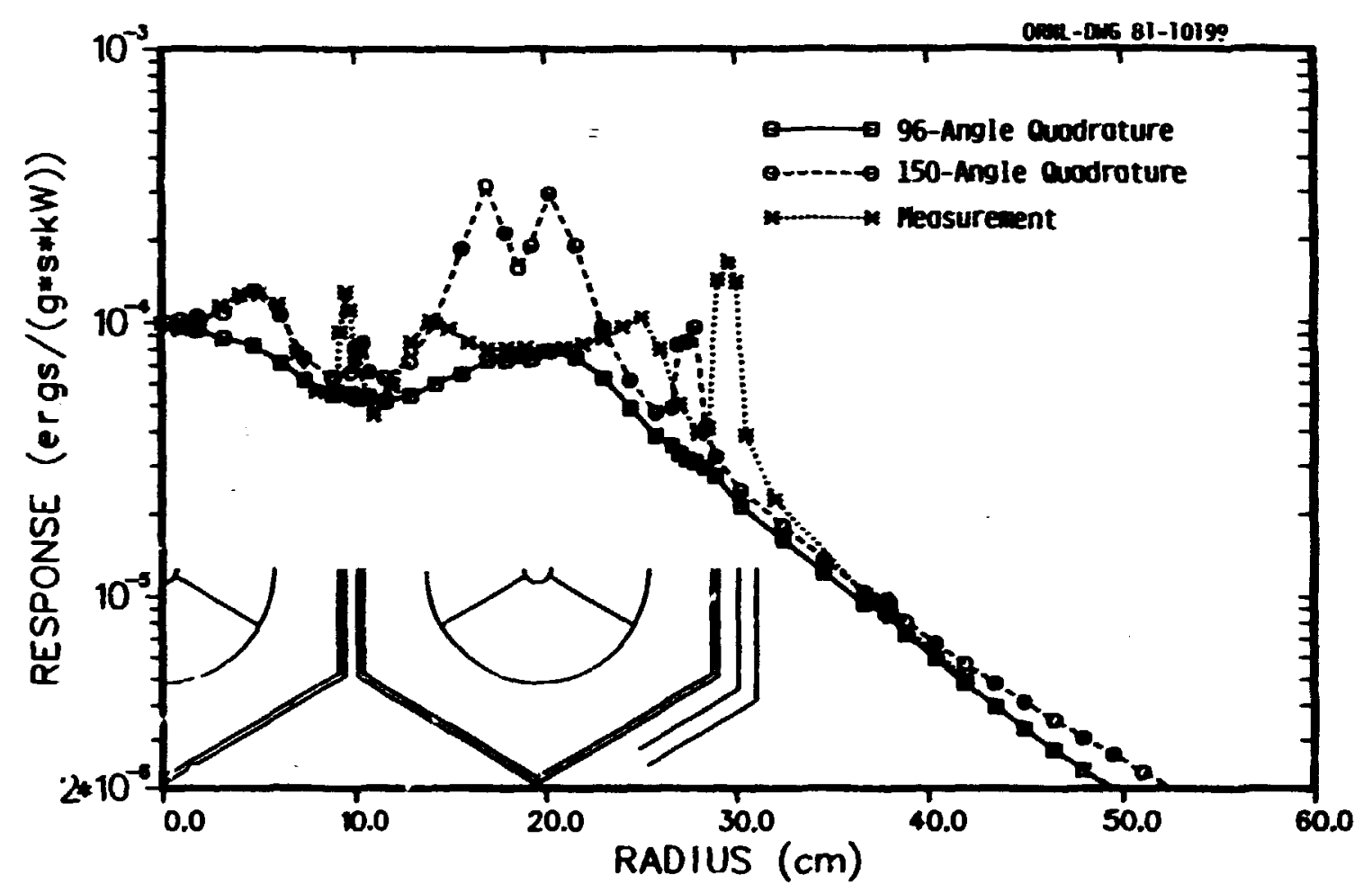

FIg. 10.17. Comparison of Mesured and DOT-Calcu Jted Hormyak Butten Rasponses 1.9 an Behind Exit shield Conf igur otion II.A. ICalculations normal ized to maserement on exis (see text in Section 10.3.2).]

IImitations, the packs at the streceling gaps ore well predicted with the 150 -angle quadrature for the L-in. Bonner ball and the Hormyck button. They are samumat overpredleted fer the s-in. Bonner ball, but that is becouse the essuption of a polnt dotector breaks jown for the larger dienter ball. Snoothing the calculation with the proper welghting function wourd broaden and lower the poeks.

The prcinent poeks In the calculated responses along the axis of the exit shleld

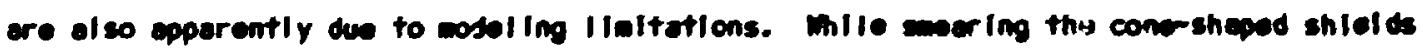
of the six outer subessemblles Into a single ennular zone an have proporly predicted the total neutron trencelssion through the shleld, It appoered to here reduced the calculates of fectivess of the shlelds. This explanetion is supported by the Dor noutron Isoflux contours shown in FIg. 10.18, which clearly show greater straining around the outer shields then eround the center shield. (Tho wodeling problem probebly would not epperer In a full iector enelyols since In thet cace a singleall calculation with reflactive boundery conditions would probebly be performed.) 


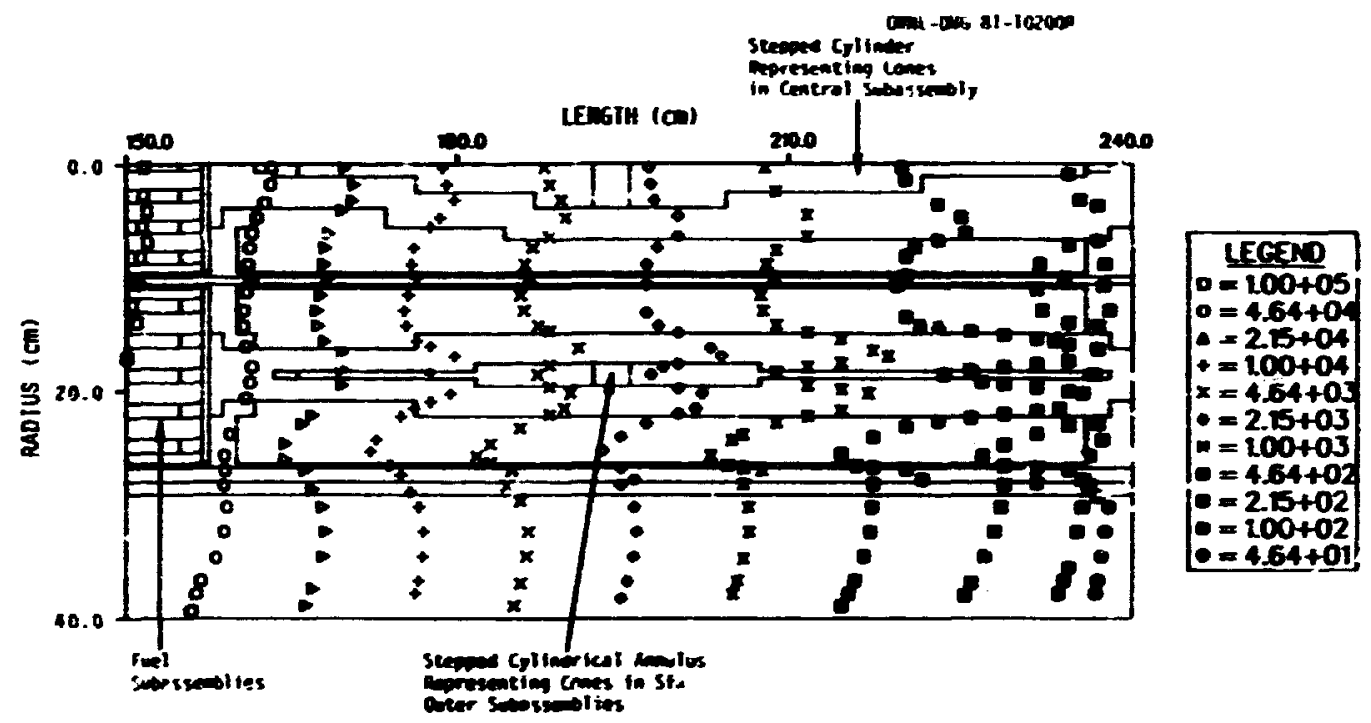

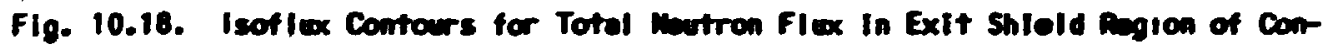
: iguration 11. A.

The Bonmer ball and Hormyel button responses wre also calculated by the bonte Carlo nathod. Excepn for the fact thet the thin Iron fins that supported the central cone section of the shlelds were neglected, the wodel for these celculetions wes noerly en exact mockup of a 1/12th segnent of the exit shleld reglon, with reflective txudary conditions used to sinulate the entire gecuetry. The source wes the boundery flux of the ful-shleld interface es generated in the oor calculation and prepered for the mise code by the auilio cods.

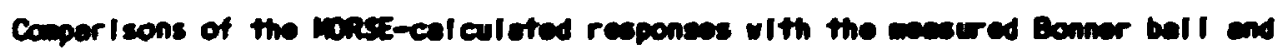
Hormyex button responses ere shown in Fles. 10.19 and 10.20 respectively. The corement

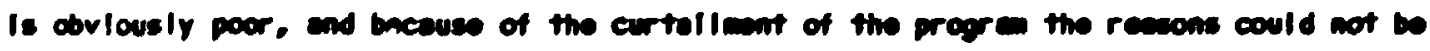
thorouniy Imastigoted.

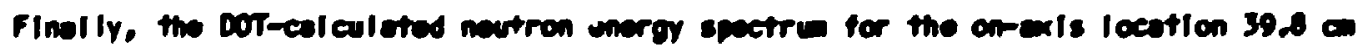

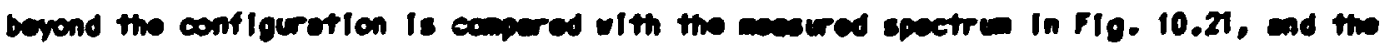

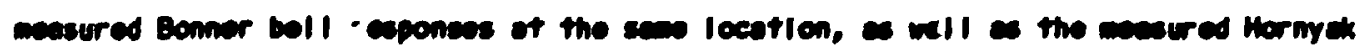
button reapense, ere given in Toble 10.4. The overpredietien of the celculated epererru

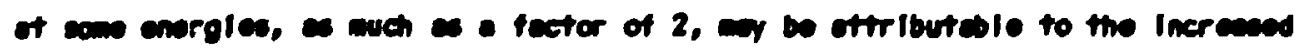

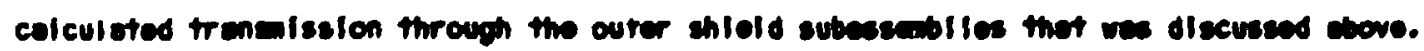



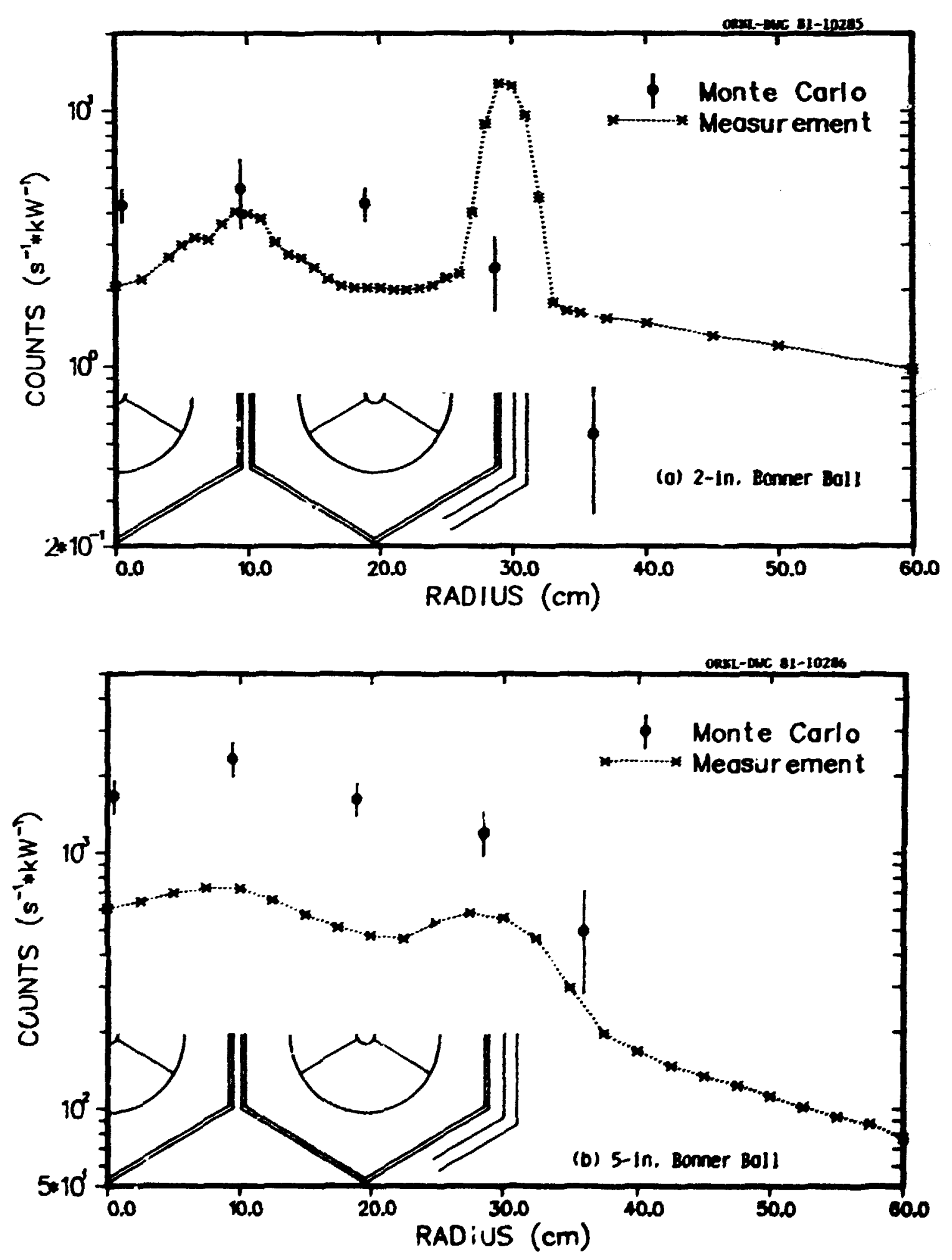

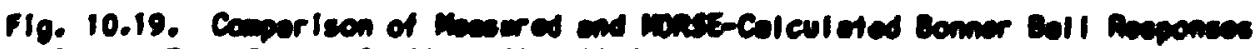
39.0 an Berond ExIt Shield Cont Iguration II.A. 


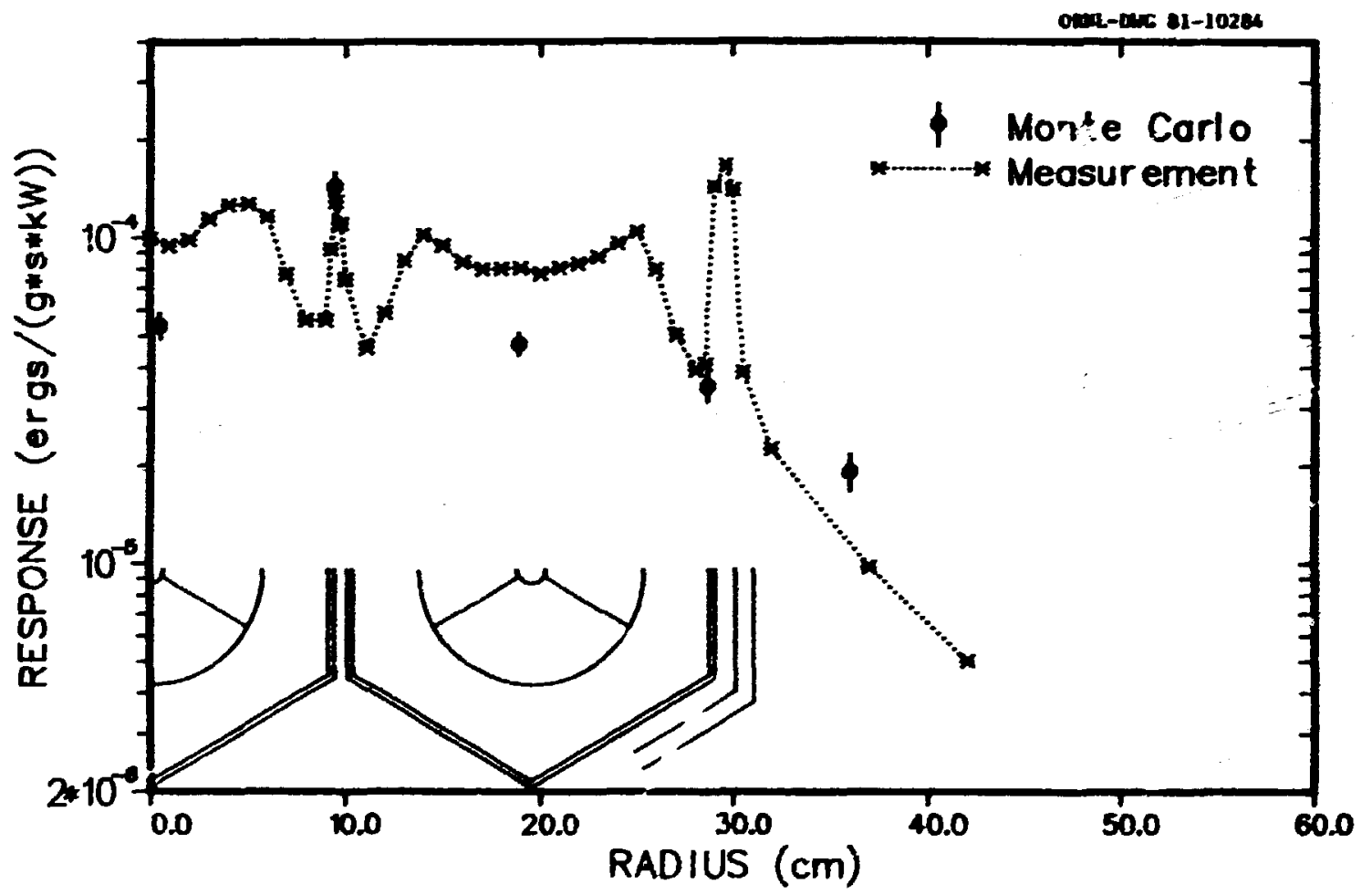

Fig. 10.20. 2omporison of Masured and mase-Calculated Hormyax Button Pesponses $1.9 \mathrm{~cm}$ Bahind Exit Shield Configuration II.A.

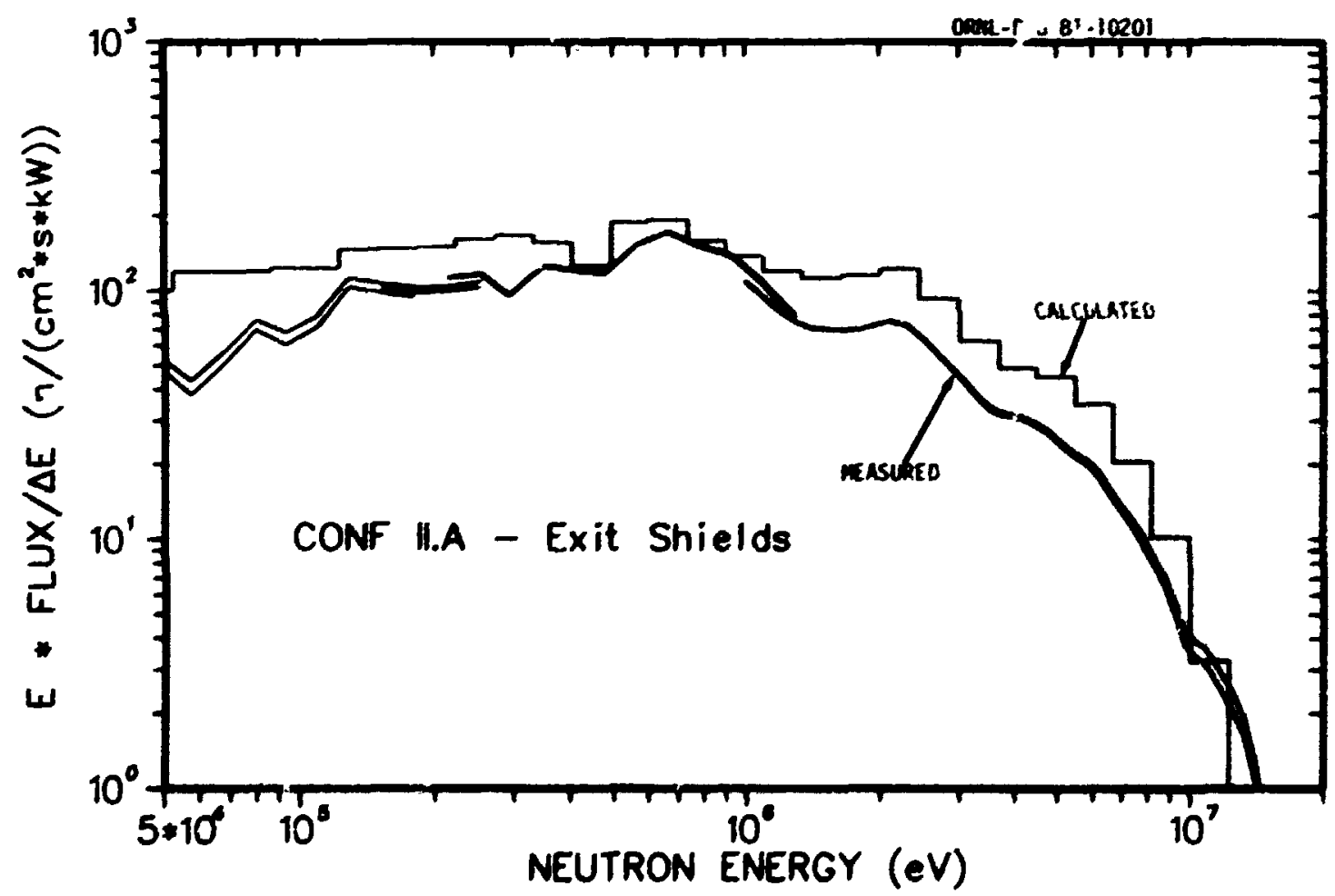

Fig. 10.21. Comparison of mesured and Dot-Celcul ated Mutron Energy Senctra on Axis 39.8 an Beyond Exit shield Conf iquretion ll.A. 


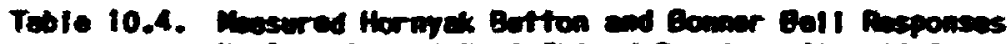
on Axis 39.8 ca Bopod Exit Sulold Conflgmetion II.A

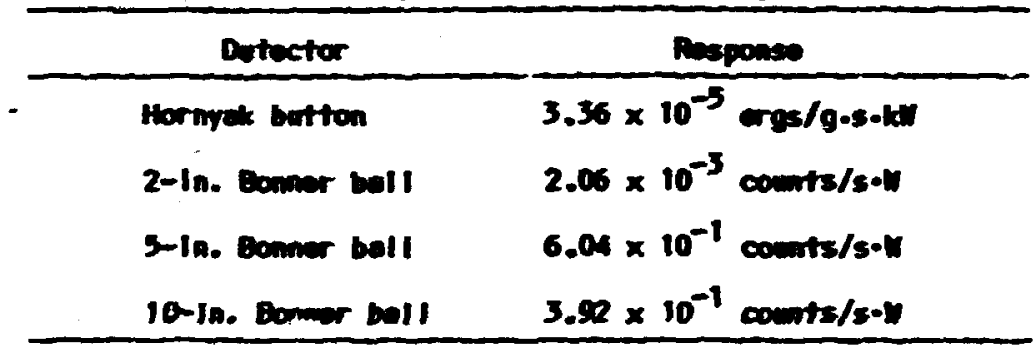

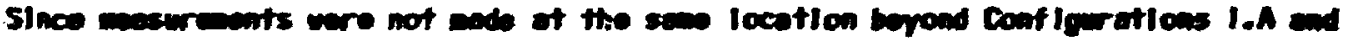

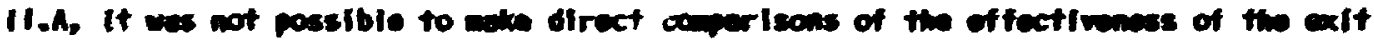

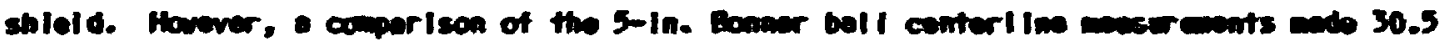

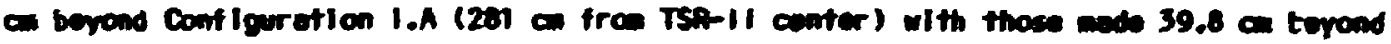

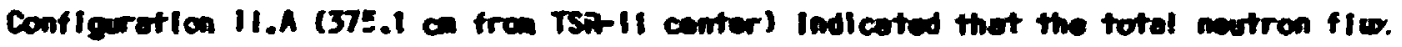

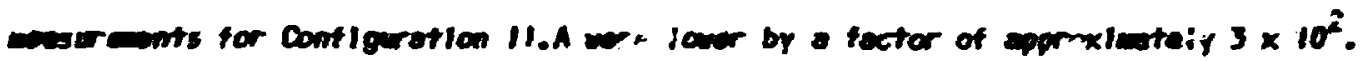
Thus, anes with the Conflgor oftion II.A fluves Increased to correct for the Increased

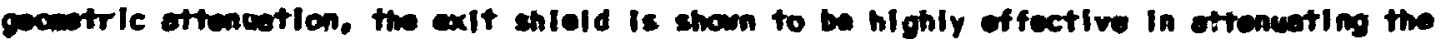
flex evering fro the core-blantert region to an accopteble level in the upper plenem.

10.3.4. Tramsport Calculations (or mosuraments) for Exit shield and Controf nod Conflouratiors

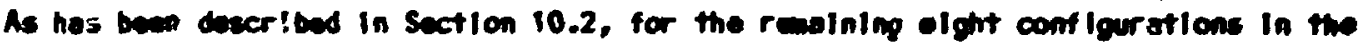

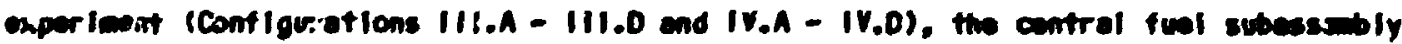
ond the central exit shlald subesembir wre reared and repleced with a control ras

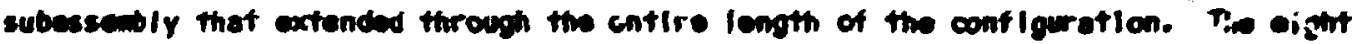
conflgurotions difiered in the position of the control rod nocketp within the subesean Iy housing end in the shieliding arovided in the housing. Baceuse of tim Ilinitations, ealy

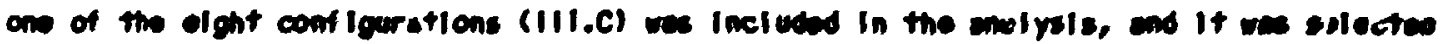
a belng reprecentative of the exics. In the exence of celculations for the other conf Ieuretions, the unmolyzed exper inantal ato ere Incl uded in this section, topother

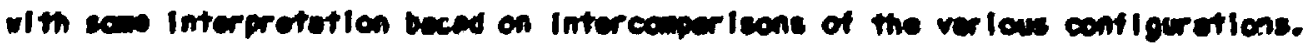

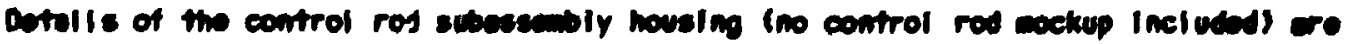

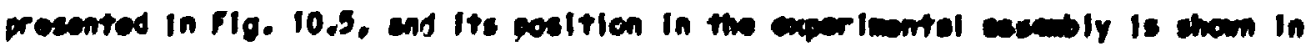


FIg.10.6. End viers of the assambly are seen In FIgs. 10.7 and 10.8. The specific configuration depleted in FIg. 10.6 Is Conflguration III.A, In whIch the subassambly housing was unsh Ielded. Conf Iguration IV.A was Idantical to Conf Iguretion III.A eacept ttat the subassebly housing wes shielded; that is, B,C fllled the region between the IIning and the wall In the Ionger section of the housing (the section In Fig. 10.6 extending fro appruxinately aldway fro the fuel section on through the exit shield section).

In the experiment three positions of the reactor control rod were mocked up with in both the unshlelded and the shleldod control rod subessemblles: the fully liserted position; the part al iy withdran position (50, inserted); and the fully withdran position. The sections of the control rod and control rod foll lwer sketched In FIg. 10.9 were combingd as required to siluliate these positions.

Flgures 10.22, 10.23 and 10.24 shor the resulting conflgurations for tha unshleldod control rod subassembly. In the conf igur stlor represerting the fully Inserted position $(111,8)$, one 60-ca section of the control rod nockup was Inserted to within $7 \mathrm{~cm}$ of the concrete shade shleld aild was fol lower by both sections of the comrol red follower. For Configuration III.C, both sectlons of the control rod mockup were used, follawed by one section of the control rod follower. And for Conflgur otion III.D, the control rod follower mockup was removed and the iwo control rod nockup sections on o w thdran to a position flush with the outter facs of the conf Iguration. The corresponding ainf Igurations for the shlelded control rod subessembly (Conflguratlons IV.A - IV.0) were ix:-:ical except thet the outer section of the subessembly housing comtained B, $C$ os noted obove.

The first mesurements with the control rod subessembly conslsted of exilat treversos within both the unshleldad and the shlelced subessebly housing with both the 2-In. Bonner ball detector and the Hornyak button datector. The results are shown In flg. 10.25. Over the flrst 100 an the slopes of the four curves ere esentially the sem, but as they epprosch the exit shield region the slopes of the two Bonner bell curves drop rester then those of the Hormyck birton curves. In perticuler. the slope for the Bonner bell curve for Conflour oftion IV.A orops replaly as the detector emfers the section of the subassembly housing contalning $\mathrm{B}_{4} \mathrm{C}$ between the Inner I Iner and the outer wall. 


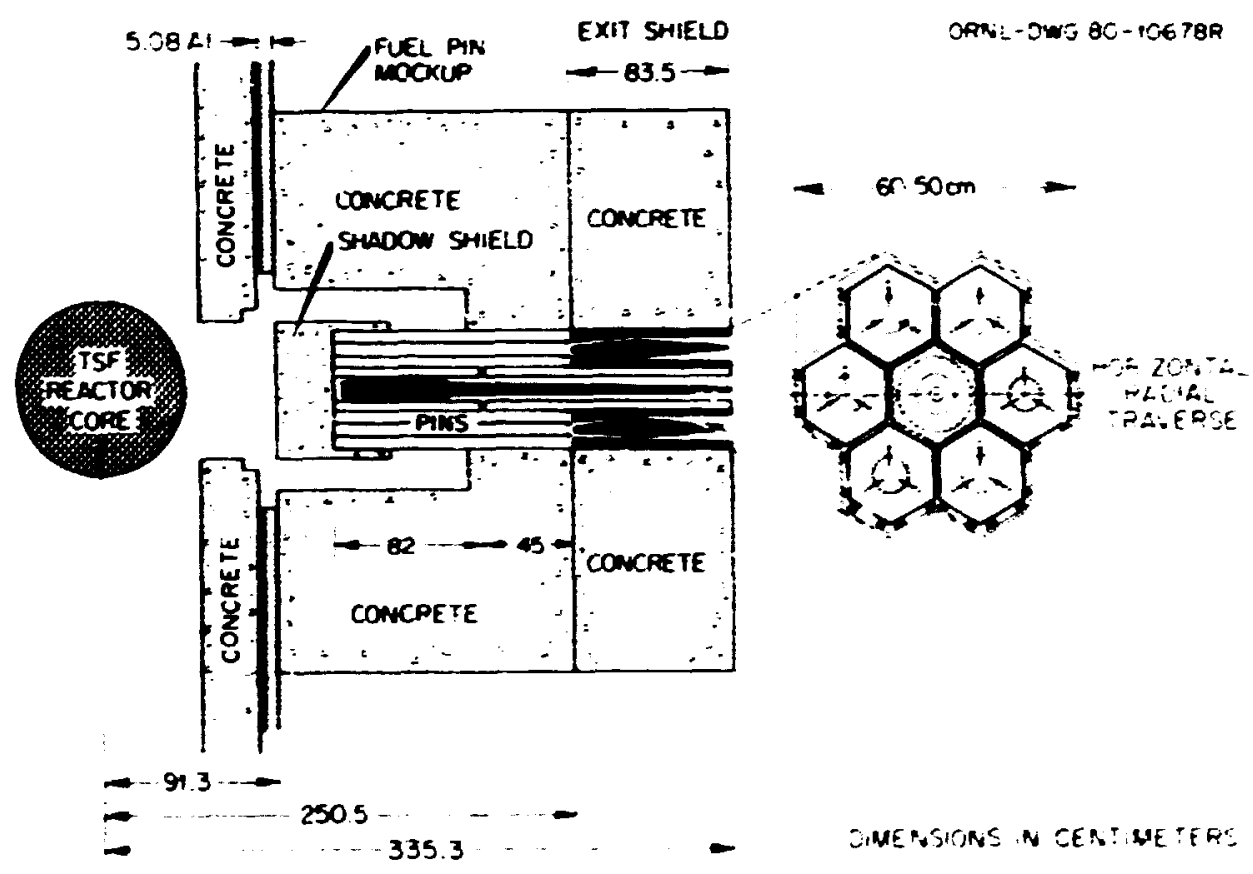

Fig. 10.22. Experimental Configuration Consisting of Exit Shield and Unshielded Control Rod Subassendy vitt. Control Rod Fully Inserted (Conflguration III.E). Note: Configuration IV.B was identical except that right-hand section of Control Rod Subassembiy housing was shielded.

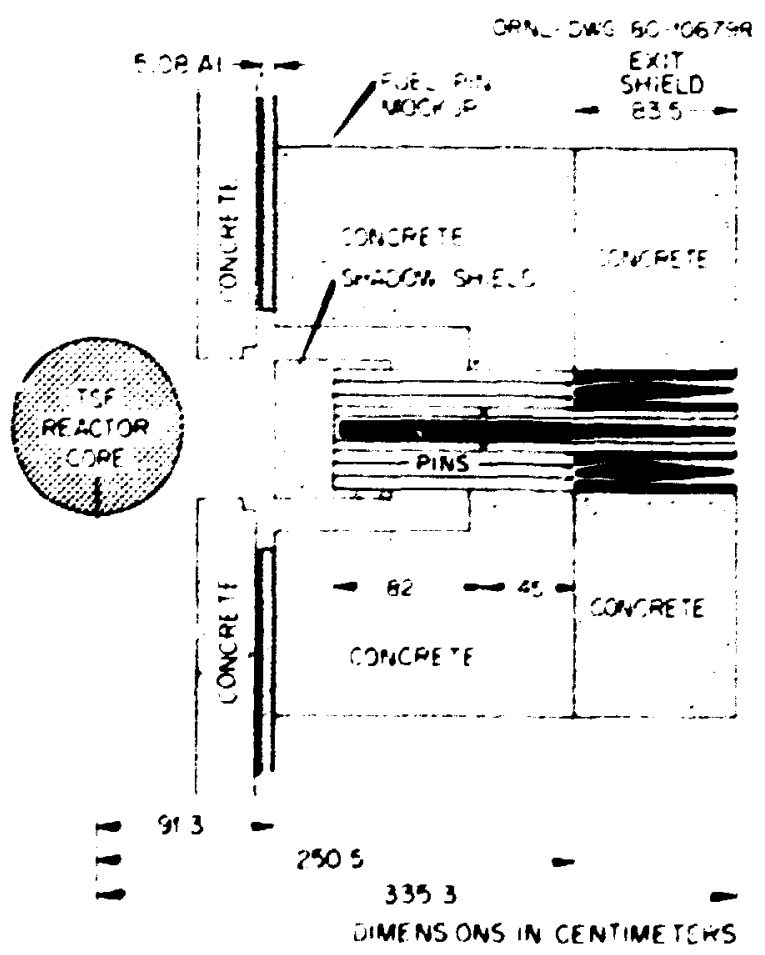

Fig. 10.23. Exparimental Configuration Censisting of Exit Shielo and Unshlel ded Control Rod Subascembily with Control Rod Partlilly Withdran (Contiguration III.C). Notes Con! Igur otion IV.C was I dentical except thet rlight-hend section of Control Rud Subassembly housing was shleldod. 


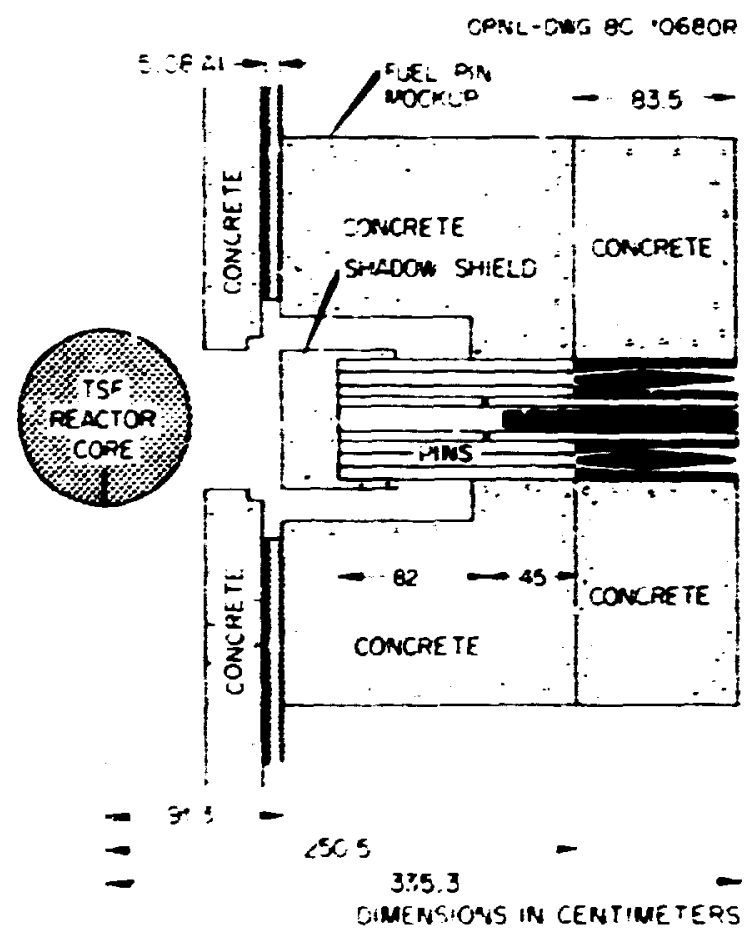

Fig. 10.24. Experimental Configuration Consisting of Exit Shielc and Unshielded Control Rod Subassembly with Control Rod Fully Withdraw :Conf Iguration III.D). Note: Configuration IV.D was I dentice: except that rightehend section of Control Rod Subassembly housing was shleldod.

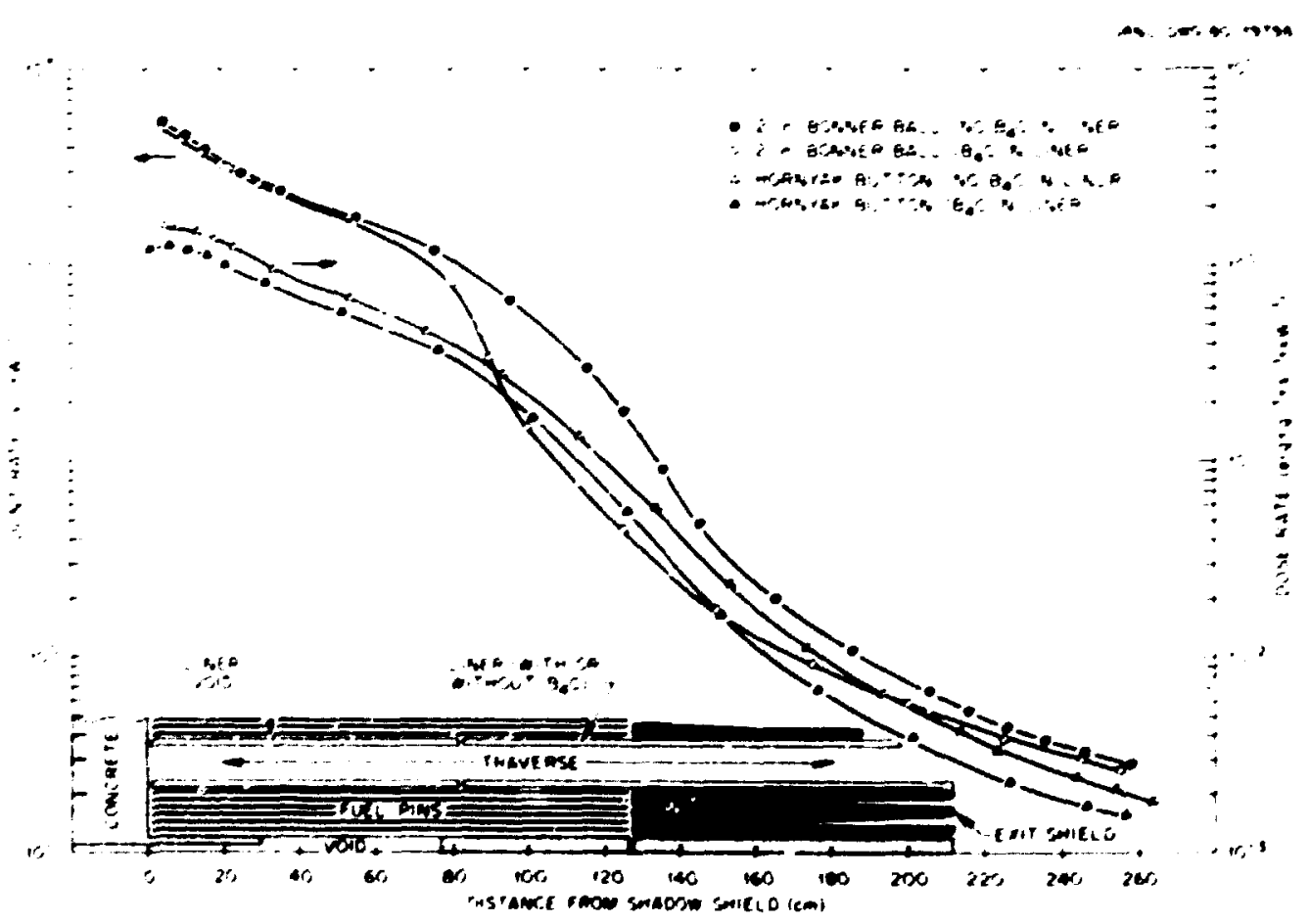

Flg. 10.25. 2-in. Bonner Bsi: and Hornyak Button Axlal Troversws Within Control Rod Subasseably: Unshlelad (ConfIguration,$: I, A$ ) and Shielad (Conflguration IV.A). 
In studying Configurations III and IV, the P. I wary co verns were whather the pre ence of the control rod subassembly coapronlsed the axlt shleld and whether the shlelding in the subassembly housirg itself was effecti re. The Hornyak button responses from radial traverses Imediately behind Configurations III.A - III.D, which JId not have the shialding, are shown In Fig. 10.26. The highest dose rate occurs, of course, for the cass in whict the control rod nockup Is absent (III.A). The next hignest is for the islly Inserted position (III.B). The dose rate then drops a factor of 3 as the control rod ackup novas to the pertially withdran position (III.C) and an additlonal factor of 5 as it moves to the fully witran dosition (iII.D). Simultaneously, the dose rates behind the 2djacent exit shields drop a factor of 2 with each step in the corifrol rod wthdrawal. In an abs-lite besis, the dose rate behind the configuration with the partlaliy withdian control rod (III.C), which presumably would be the most likely position of the control rod in the GCFR, Is about the sane as that beyond the solld exIt shleld configuration $(11 . A)$ (see Fig. 10.17).

Simllar Hornyak bution responses for Conf Igurations IV.A - IV.D presented in FIg. 10.27 show that on the avsage the dose rates are reduced by a factor of about 2 when the BC shield is includec in the control rod subassenbly housing. The largest reduction Is for the partially vithdrawn position of the control rod mockup (a factor of 3 ) and the snallest is for tr.: fully withdrawn position (a factor of 1.3). Obvicusly. Including the B.C would be worth the extra expense and effort.

Finally, measured 2- and 5-In. Bonner Dall responses along radial troverses $39.8 \mathrm{~cm}$ beyond the configuratlons are shown In FIgs. 10.28 and 10.29 for the unshielded and shlel ded subassemblles, respectlvely, and the seme trends seen in the Hornyak button traverses are apperent. Conterline measurements from these traverses, plus centerlline measuraments at the same location with tha " $0-I n$. Bonner ball and the Hornyat button, are presented in Tables 10.5 and 10.6 .

The analysis performed for Contlgurstion III.C was performed with the DOT code usling the cyllnorlecI R-Z model shown In FIg. 10.30. As noted above, In this conf Iguration a 120-on length of the cyllndrlcal control rod mockup was insarted tc within $7 \mathrm{~cm}$ of the concrete shadow shleld and wes followed by control rod follower mockup. These sectlons were represented In the model as ste ned cylinders, and, as bafore, other regions of the conflguration were reprecanted os cyllndrical anni'l. 


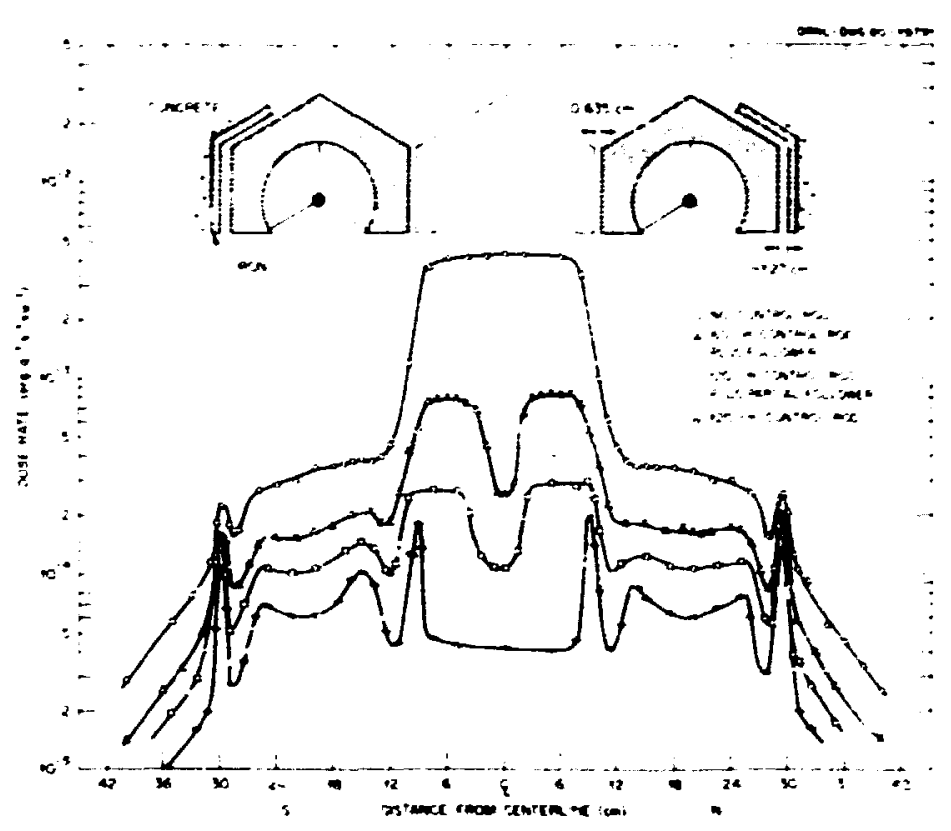

Fig. 10.26. Measured Hornyak. Button Responses $1.9 \mathrm{~cm}$ Behino Cunfigurations with Exit Shleld and Unshiel ded Control Rod Subassembly (Configurations III.A-III.D).

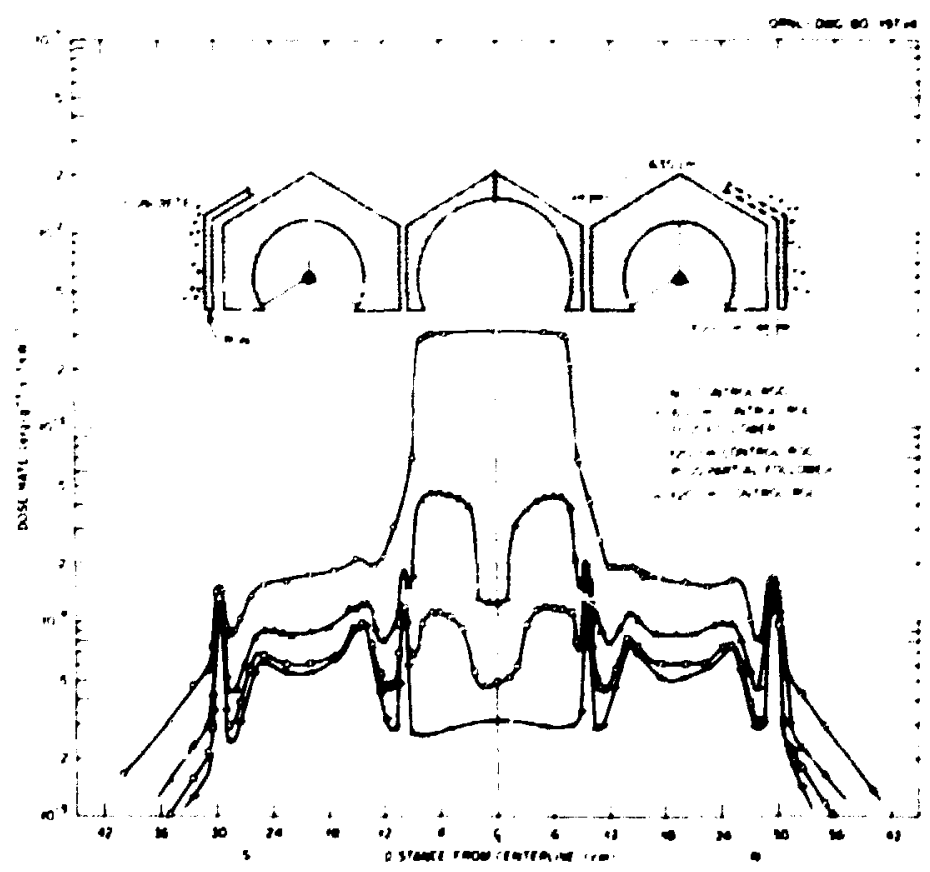

Fig 10.27. Mesured Hornyek Button Respenses 1.9 cm Behind Conflguratlons $w^{\circ}$ in Exit Shleld and Shlelded Control Rod Subassembl les (Configurations IV.A-IV.D). 


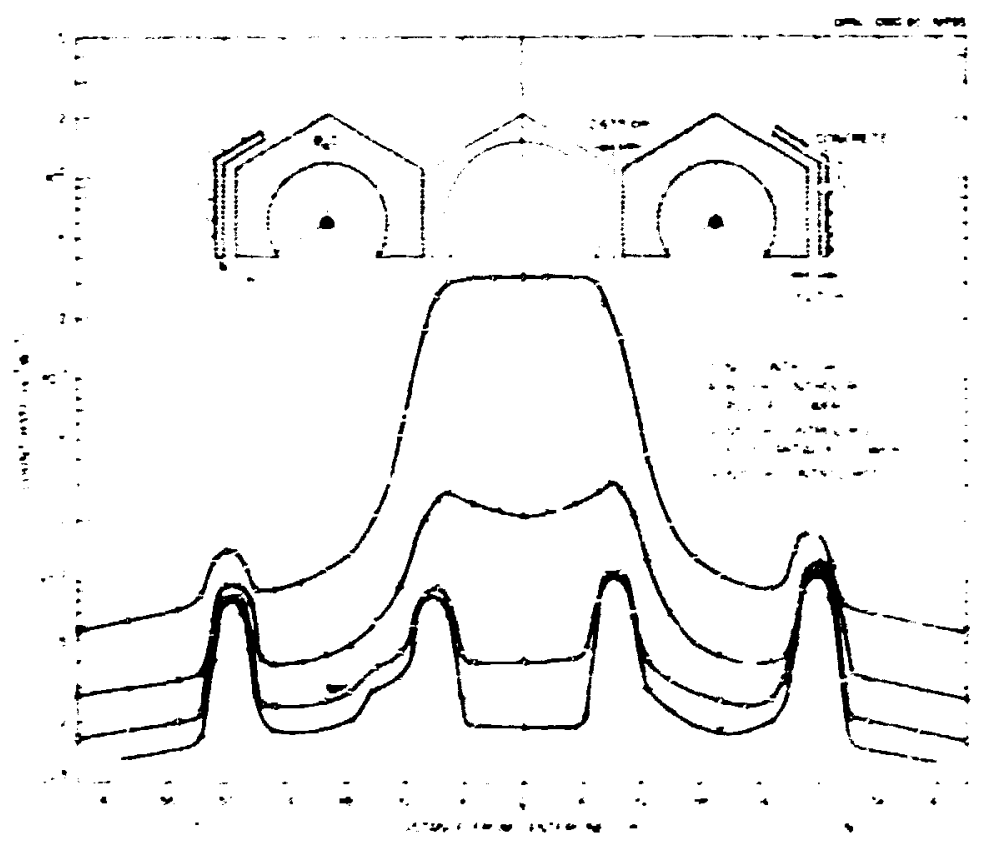

(a) 2-in. Bonrer Ball

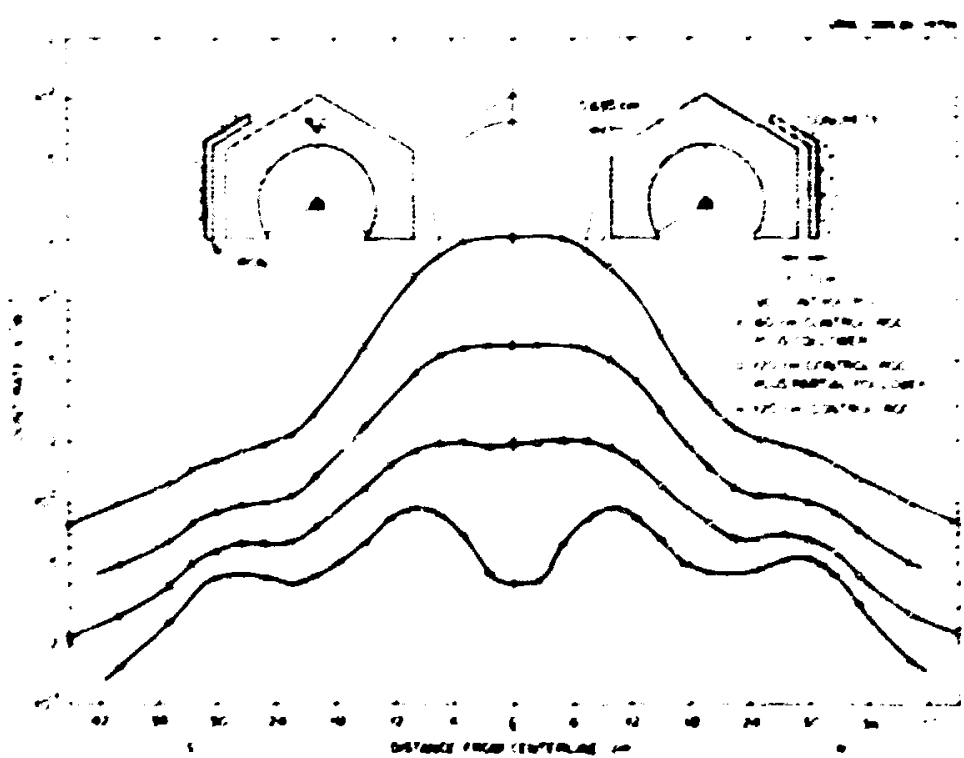

(b) 5-in. Bnnrar Ball

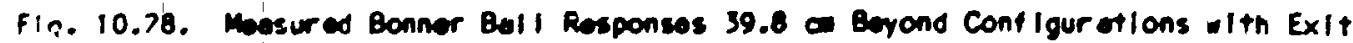
Shleld and Unshlelad Control Rod Subessumbly (Conflgur ot Ions 111. A-111.D). 


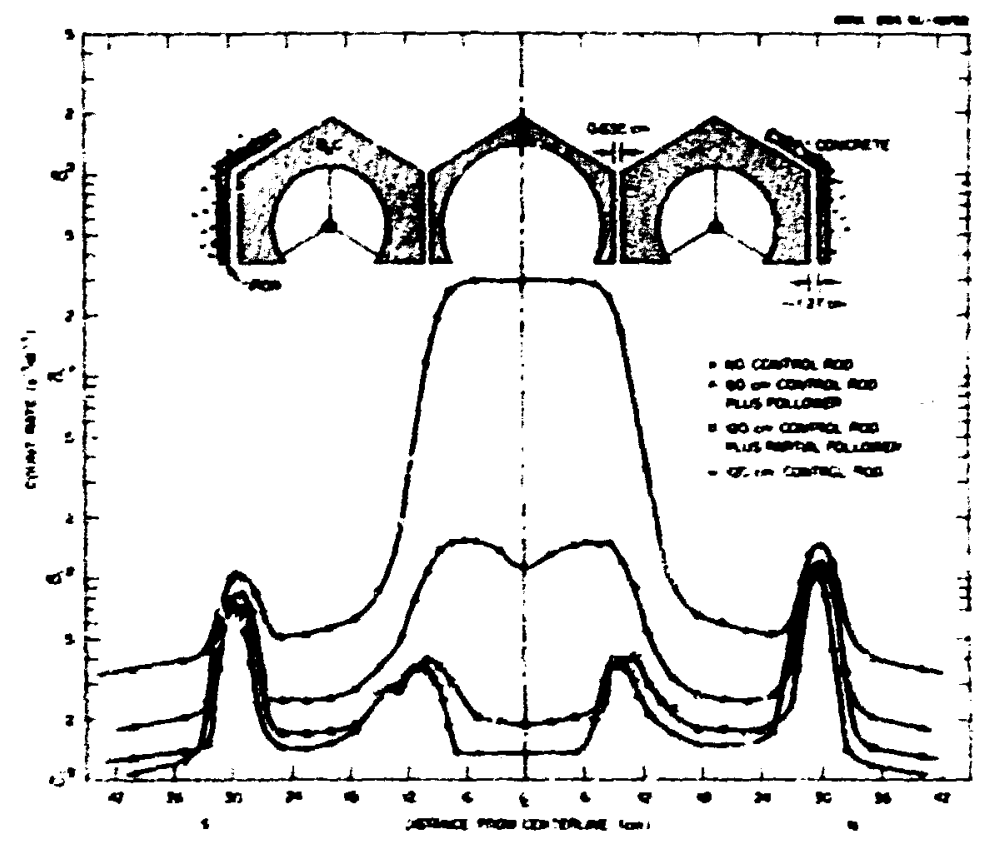

(a) 2-In. Bonnor Ball

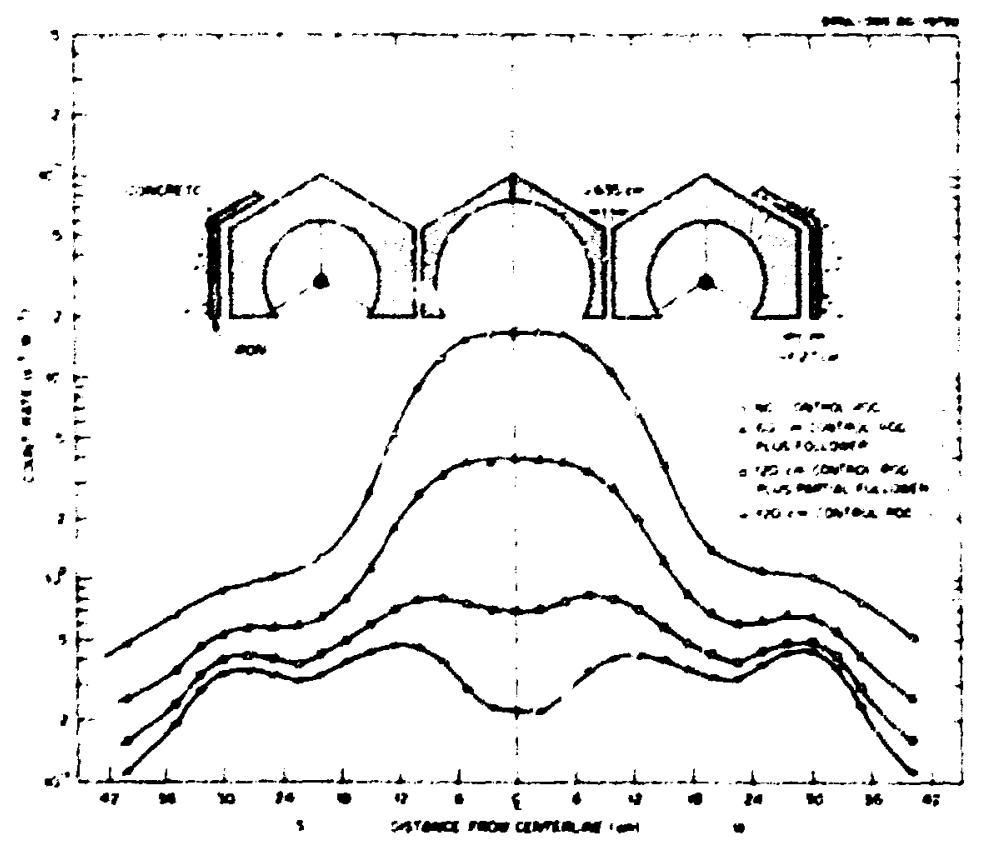

(b) S- in. Bonner Bell

FIg. 10.29. Mesures Bonner Eali Responess $39.8 \mathrm{~cm}$ Bnyond Conf iguretions with Ex!t Shield and Shiel ded Control Rod Subasenoly (Cont igurations IV.A-IV.O). 
Tedle 10.5. Mnsured Horayck Button and Besmor Ball Responses on Axis 39.8 an Byond ExIt Shleld/Control Rod Comlizeretlons III.A - III.D

\begin{tabular}{|c|c|c|c|c|}
\hline & Mormyck Eurtion & Bomer Ball & Response & $(\operatorname{cosent} / \cdot=5 \mid n)$ \\
\hline Cont lgeration & $(\operatorname{cog} g / g-5-k \omega)$ & $2-10.88$ & $5=\ln .88$ & $10-1 n .68$ \\
\hline III.A & $2.17(-3)=$ & $3.20(-1)$ & $2.00(1)$ & $1.18(1)$ \\
\hline 111.8 & $3.33 i-4)$ & $2.09(-2)$ & $6.01(0)$ & $3.22(0)$ \\
\hline III. & $1.16(-4)$ & $4.02(-3)$ & $1.95(0)$ & $1.13(0)$ \\
\hline $11 ! .0$ & $2.29(-5)$ & $1.93(-3)$ & $4.00(-1)$ & $4.60(-1)$ \\
\hline
\end{tabular}

Toble 10.6. Masured Mormyak Button and Bonner Bal I Responses on AxIs 39.8 con Berond ExIt Shleld/Control Rod Cont Iguratlons IV.A - IV.D

\begin{tabular}{|c|c|c|c|c|}
\hline \multirow[b]{2}{*}{ Conf Iguration } & \multirow{2}{*}{$\begin{array}{c}\text { Hornyak Button } \\
\text { Dose Rote } \\
\text { (ergsig-s -kw) }\end{array}$} & \multirow{2}{*}{$\frac{\text { Bonner Bal I }}{2-\ln . \mathrm{Ba}}$} & Rospunse & \multirow{2}{*}{$\frac{(\text { counts } / \cdot s \cdot 1)}{10-\ln .88}$} \\
\hline & & & s-in. BB & \\
\hline IV.A & $1.64(-3)=$ & $2.98(-1)$ & $1.69(1)$ & $9.42(0)$ \\
\hline IV.B & $1.81(-4)$ & $1.15(-2)$ & $4.01(0)$ & $2.05(0)$ \\
\hline IV.C & $3.83(-5)$ & $1.8(1-3)$ & $7.04(-1)$ & $4.73(-1)$ \\
\hline IY.D & $1.67(-5)$ & $1.38(-3)$ & $2.28(-1)$ & $2.01(-1)$ \\
\hline
\end{tabular}

moad: $1.64 \times 10^{-3}$.

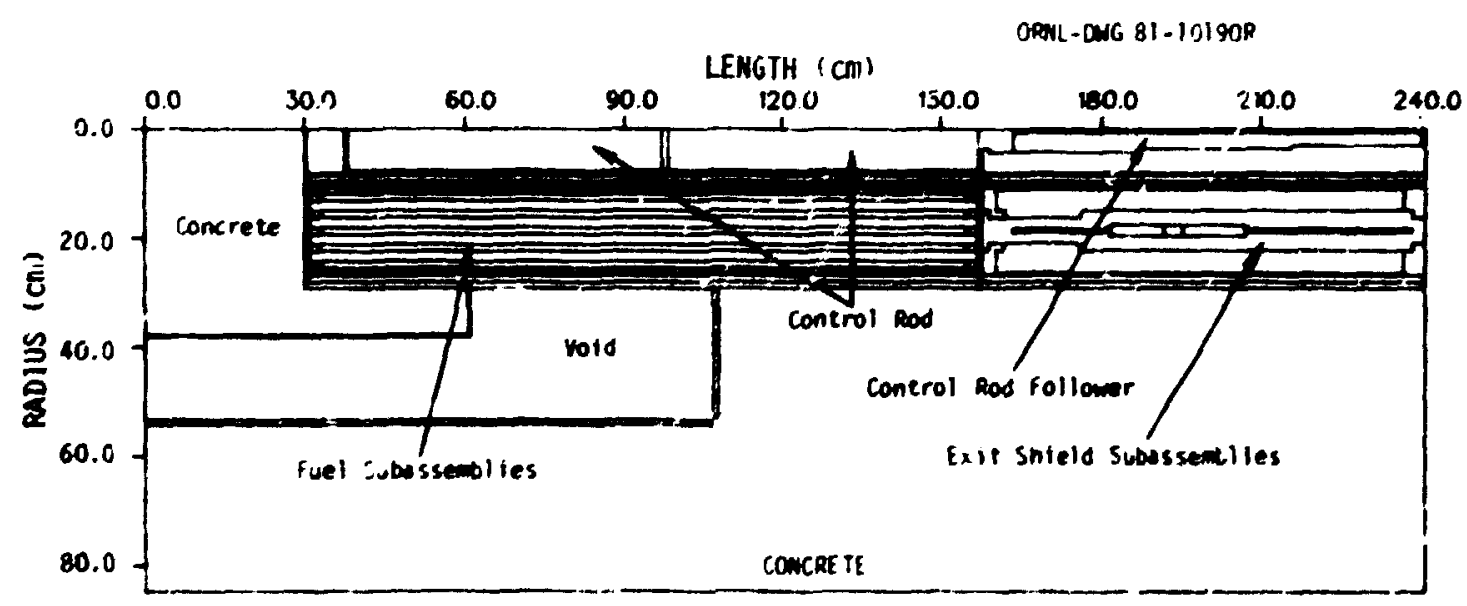

Fig. 10.30. Tro-Dimanslonel Model Leed for DOT Colculotions of Configuretion III.C. Model hed 98 axial Intervals, 61 redial intervals In the fwal reaton, and 63 redial Intervels in the shield region. 
Since both the fual region and the exit - hield region vere codifled in Configuration III.C. It was necessery to Include the full configuretion in the calculation and to use the original boundery sowrce. Mgaln the calculetion wes performed wth the 51 -group GCFR $P_{3}$ cross suct lons and the 150-angle blased quadreture sest.

The resulting calculated Hurnyak I utton and Bonner ball responses bercod ConfIguretIon III.C are comared with the moesured responses In FIgs. 10.31 ard 10.32 respectively. Mverall the egreenent Is exccilent, with the same exceptlons as has been ciscassed earlfer. That is, def I-Inancles In the calculational modal Introducad peaks In the colculated curve. Aiso, it should be remenbered that the calculated Hornyel button data ori normal lzed to the measured date at the centerline.

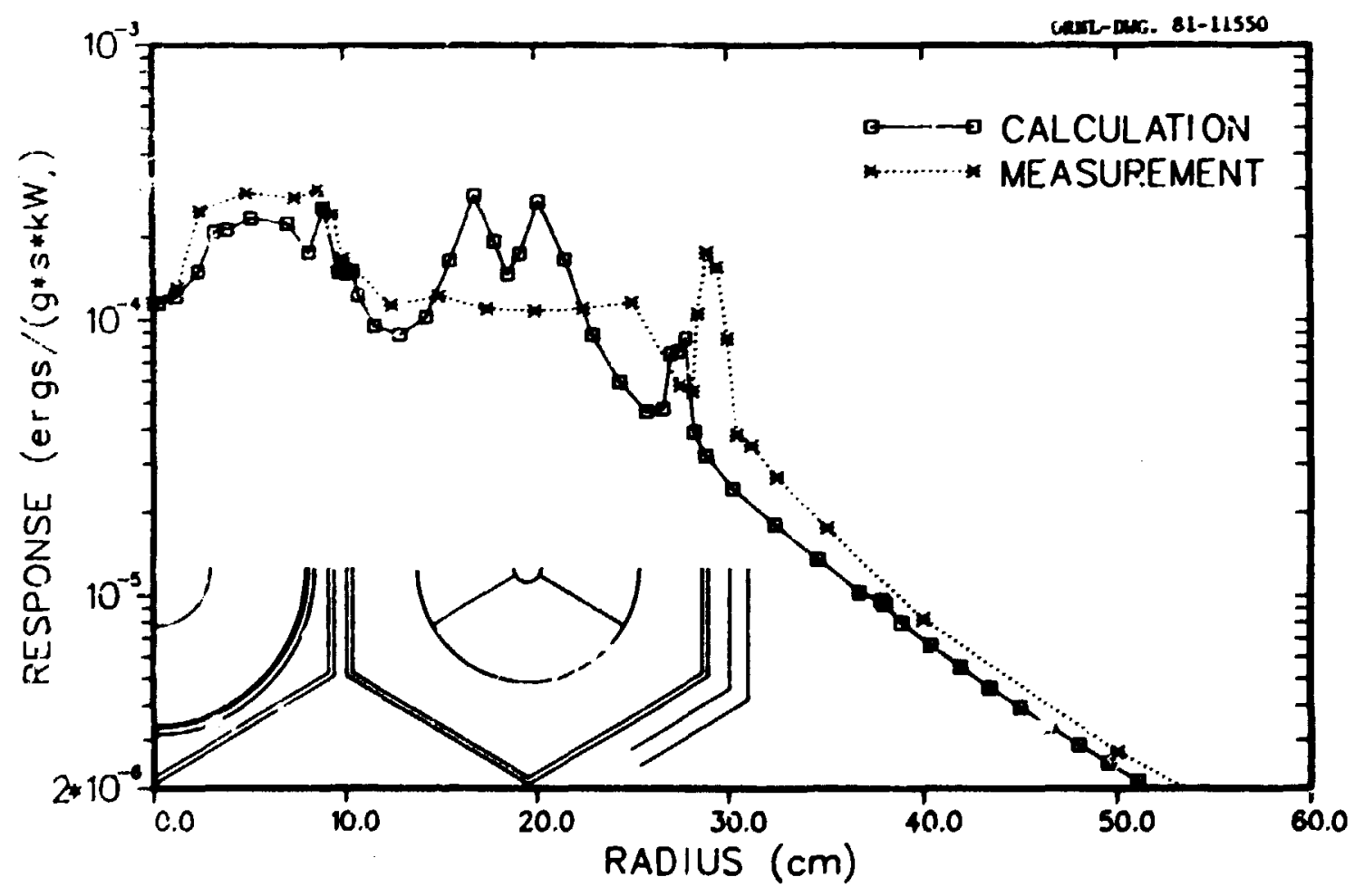

FIg. 10.31. Comperison of Mosured and Calcul eted Hornyck Button Rosponces $1.9 \mathrm{~cm}$ Behind Exit Shleid and Unshlelded Control Ros Subesecmily with Control Rod Partlal Iy withdrean (Conf igur ot ion III.C). 

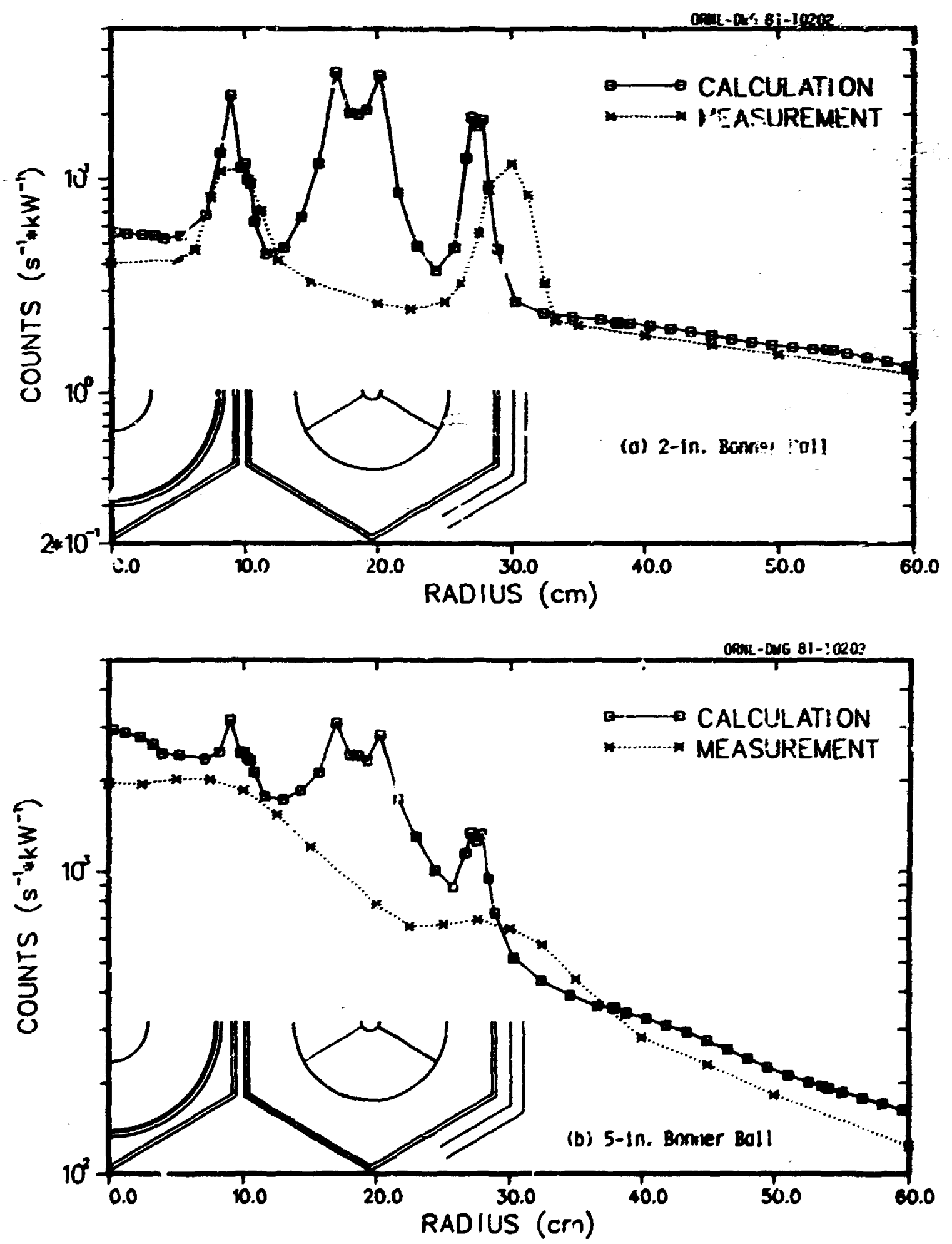

FIb. 10.32. Comperison of Mnesures and Colculeted Bomner Bell Besponeses 39.8 an Beyond Exft Shleld and Unchleleed Control Rod Subecsembly with Control Rod Portial Iy withdrean contiguretion HI.C). 


\section{6. conausions}

ThIs experinent togather with Its abbrovlated analysis hos shown that the GCrR exIt shleld weuld bo highly effoctive In attenueting the total flux directed upuerd fro the core and blenket before It reeches the plenum region, and, worecver, that the shleld would not bo compramised by control rod penetretions. In fact, a comparison of the mesured neutron fluxes emerging frce on exit shleld conflguration ulth and utthout a nockup of a control rod subassembly In the center of the shleld shows that when B $C$ shliglding ves Incl uded in the control rod subassebly housing. the flux diracily butind the control rad sube.ssembly was lower then that directly behind an exit shlels subassasbly in the sane locatlon for most positions of a control rod wockup ulthin the subessembly. Furttermore, the neutron fl wac. energing from the adjacent exit shlel ds vere al so reduced.

Ant iysis of a fer of the configurations vith the discrete ordinotes code DOT resulted in good agrement between the moasured and calculated results, Indlcating that the analytical nothod Is adequate for use as a design method in the exit shield reglon of the SCFR.

\subsection{REFERENCES}

1. F. ‥ Muckenthaler, J. -. Hull, and J. J. Monning, "GCFR Plenum Shleld Design - Exit Shield Experiment," ORal/TM-7715 (May, 1981).

2. D. T. Ingarsoli and S. N. Cramer, "Final Analysls of the GCFR Exit Shield Integral Experiment," ORNK/TM-7839 (July, 1981 ). 